\title{
BIBLIOGRAPHY, INDICES, AND DATA SOURCES OF WATER-RELATED STUDIES, UPPER COLORADO RIVER BASIN, COLORADO AND UTAH, 1872-1995
}

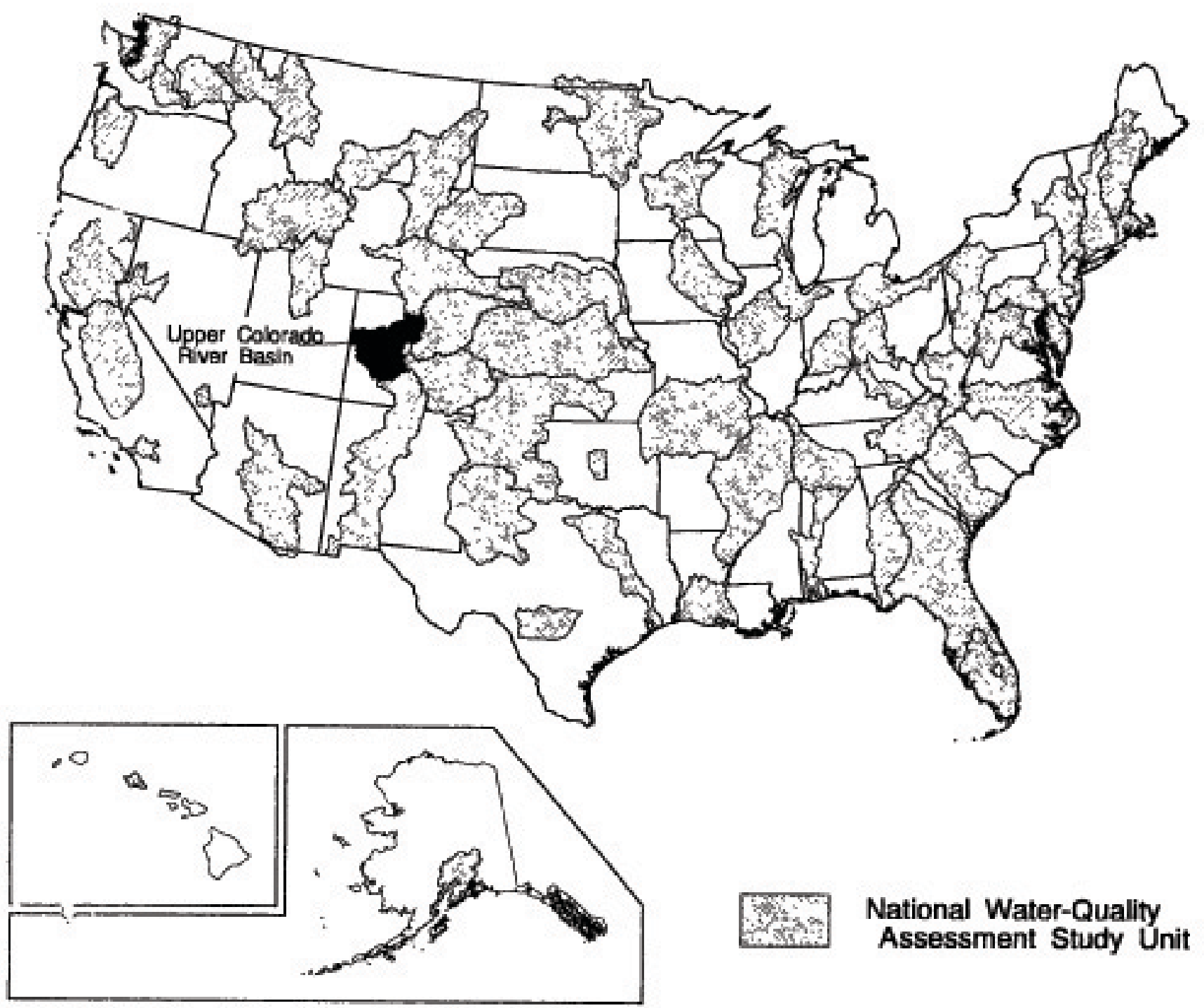

\section{U.S. GEOLOGICAL SURVEY \\ Open-File Report 95-450}

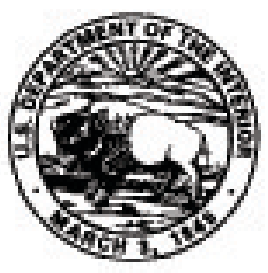




\section{BIBLIOGRAPHY, INDICES, AND DATA SOURCES OF WATER-RELATED STUDIES, UPPER COLORADO RIVER BASIN, COLORADO AND UTAH, 1872-1995}

by Nancy J. Bauch and Lori E. Apodaca

U.S. GEOLOGICAL SURVEY

Open-File Report 95-450

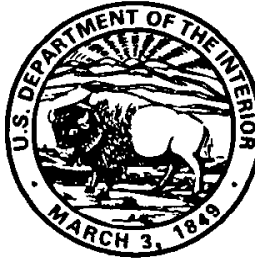




\section{U.S. DEPARTMENT OF THE INTERIOR \\ BRUCE BABBITT, Secretary \\ U.S. GEOLOGICAL SURVEY \\ Gordon P. Eaton, Director}

The use of trade, product, industry, or firm names is for descriptive purposes only and does not imply endorsement by the U.S. Government.

For additional information write to:

District Chief

U.S. Geological Survey

Box 25046, MS 415

Denver Federal Center

Denver, CO 80225
Copies of this report can be purchased from:

U.S. Geological Survey

Earth Science Information Center

Open-File Reports Section

Box 25286, MS 517

Denver Federal Center

Denver, CO 80225 


\section{FOREWORD}

The mission of the U.S. Geological Survey

(USGS) is to assess the quantity and quality of the earth resources of the Nation and to provide information that will assist resource managers and policymakers at Federal, State, and local levels in making sound decisions. Assessment of water-quality conditions and trends is an important part of this overall mission.

One of the greatest challenges faced by waterresources scientists is acquiring reliable information that will guide the use and protection of the Nation's water resources. That challenge is being addressed by Federal, State, interstate, and local water-resource agencies and by many academic institutions. These organizations are collecting water-quality data for a host of purposes that include: compliance with permits and water-supply standards; development of remediation plans for a specific contamination problem; operational decisions on industrial, wastewater, or watersupply facilities; and research on factors that affect water quality. An additional need for water-quality information is to provide a basis on which regional and national-level policy decisions can be based. Wise decisions must be based on sound information. As a society we need to know whether certain types of water-quality problems are isolated or ubiquitous, whether there are significant differences in conditions among regions, whether the conditions are changing over time, and why these conditions change from place to place and over time. The information can be used to help determine the efficacy of existing waterquality policies and to help analysts determine the need for and likely consequences of new policies.

To address these needs, the Congress appropriated funds in 1986 for the USGS to begin a pilot program in seven project areas to develop and refine the National Water-Quality Assessment (NAWQA) Program. In 1991, the USGS began full implementation of the program. The NAWQA Program builds upon an existing base of water-quality studies of the USGS, as well as those of other Federal, State, and local agencies. The objectives of the NAWQA Program are to:

-Describe current water-quality conditions for a large part of the Nation's freshwater streams, rivers, and aquifers.
-Describe how water quality is changing over time.

-Improve understanding of the primary natural and human factors that affect water-quality conditions.

This information will help support the development and evaluation of management, regulatory, and monitoring decisions by other Federal, State, and local agencies to protect, use, and enhance water resources.

The goals of the NAWQA Program are being achieved through ongoing and proposed investigations of 60 of the Nation's most important river basins and aquifer systems, which are referred to as study units. These study units are distributed throughout the Nation and cover a diversity of hydrogeologic settings. More than two-thirds of the Nation's freshwater use occurs within the 60 study units and more than two-thirds of the people served by public water-supply systems live within their boundaries.

National synthesis of data analysis, based on aggregation of comparable information obtained from the study units, is a major component of the program. This effort focuses on selected water-quality topics using nationally consistent information. Comparative studies will explain differences and similarities in observed water-quality conditions among study arcas and will identify changes and trends and their causes. The first topics addressed by the national synthesis are pesticides, nutrients, volatile organic compounds, and aquatic biology. Discussions on these and other waterquality topics will be published in periodic summaries of the quality of the Nation's ground and surface water as the information becomes available.

This report is an element of the comprehensive body of information developed as part of the NAWQA Program. The program depends heavily on the advice, cooperation, and information from many Federal, State, interstate, Tribal, and local agencies and the public. The assistance and suggestions of all are greatly appreciated. 


\section{CONTENTS}

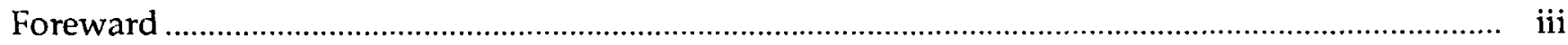

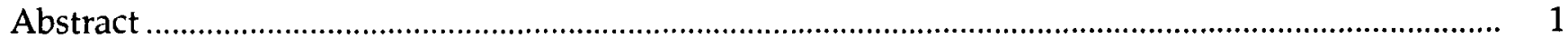

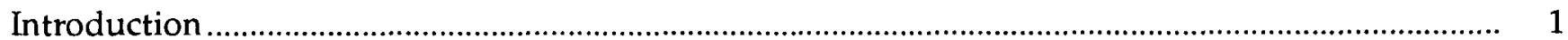

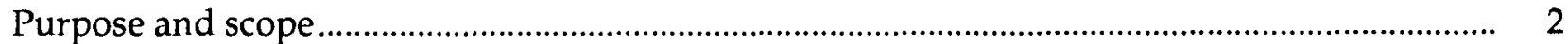

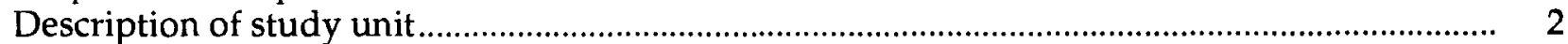

Sources of water-related information .............................................................................. 4

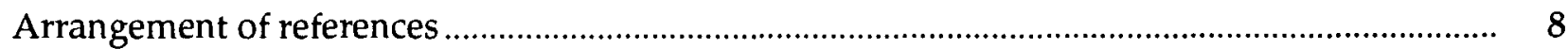

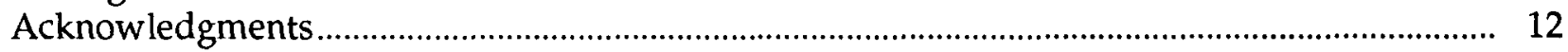

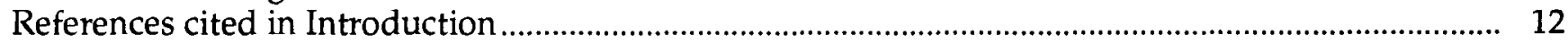

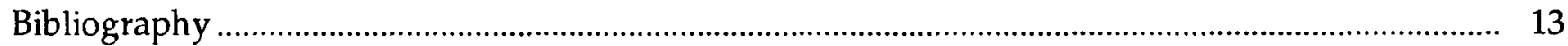

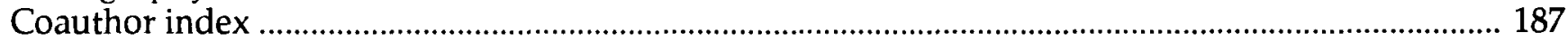

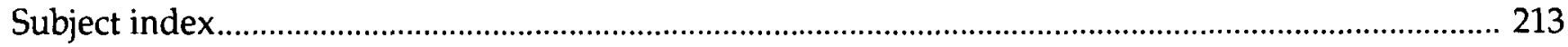

\section{FIGURES}

1. Map showing location of the Upper Colorado River Basin study unit ................................. 3

2. Chart showing keywords used in computerized retrieval of water-related studies from DIALOG data bases.

\section{TABLES}

1. List of data bases searched for water-related studies about the Upper Colorado River Basin study unit.

2. Sources of water-related data for the Upper Colorado River Basin study unit

\section{CONVERSION FACTORS}

\begin{tabular}{rll}
\hline Multiply & By & To obtain \\
\hline mile $(\mathrm{mi})$ & 1.609 & kilometer \\
square mile $\left(\mathrm{mi}^{2}\right)$ & 2.590 & square kilometer \\
\hline
\end{tabular}

Degree Celsius $\left({ }^{\circ} \mathrm{C}\right)$ may be converted to degree Fahrenheit $\left({ }^{\circ} \mathrm{F}\right)$ by using the following equation:

$$
\circ \mathrm{F}=9 / 5\left({ }^{\circ} \mathrm{C}\right)+32 \text {. }
$$




\title{
BIBLIOGRAPHY, INDICES, AND DATA SOURCES OF WATER-RELATED STUDIES, UPPER COLORADO RIVER BASIN, COLORADO AND UTAH, 1872-1995
}

\author{
By Nancy J. Bauch and Lori E. Apodaca
}

\begin{abstract}
As part of the U.S. Geological Survey's National Water-Quality Assessment Program, current water-quality conditions in the Upper Colorado River Basin in Colorado and Utah are being assessed. This report is an initial effort to identify and compile information on water-related studies previously conducted in the basin and consists of a bibliography, coauthor and subject indices, and sources of available water-related data. Computerized literature searches of scientific data bases were carried out to identify past water-related studies in the basin, and government agencies and private organizations were contacted regarding their knowledge or possession of water-related publications and data. Categories of information in the bibliography include: aquatic biology, climate, energy development, geology, land use, limnology, runoff, salinity, surface- and ground-water hydrology, water chemistry, water quality and quantity, and water use and management. The approximately 1,400 indexed references date from 1872 through February 1995 and include books, journal articles, maps, and reports. In many instances, an abstract has been provided for a given reference. Sources of water-related data in the basin are included in a table.
\end{abstract}

\section{INTRODUCTION}

In 1991, the U.S. Geological Survey (USGS) began full implementation of the National WaterQuality Assessment (NAWQA) Program. The major goals of the NAWQA Program are: to describe current water-quality conditions for a large part of the Nation's freshwater streams, rivers, and aquifers; to describe how water quality is changing over time; and to improve understanding of the primary natural and human factors that affect water-quality conditions. The water-quality information collected and analyzed by the NAWQA Program will be useful to Federal, State, and local water managers and policy makers in decision making to protect, use, and enhance water resources.

A major feature of the NAWQA Program is the national investigation of water-quality conditions on different regional scales. The primary building blocks for the program are the ongoing and proposed studies of 60 hydrologic systems, referred to as study units, that include parts of the Nation's principal river basins and aquifer systems. These study units range in size from under 1,000 to more than 60,000 square miles and include a variety of hydrologic and geologic settings. More than two-thirds of the Nation's freshwater use and population served by public water-supply systems are represented by the study units. Twenty study-unit investigations began in 1991, an additional 20 started in 1994, and the remaining 20 are scheduled to begin in 1997. These investigations form the basis on which a national synthesis and assessment of comparable water-quality information will be conducted. The Upper Colorado River Basin in Colorado and Utah was one of the 20 study units that began in 1994. 
In undertaking a multidisciplinary basinwide assessment of water quality, sources of available water-related information for the basin, both descriptive and quantitative, need to be identified; therefore, in 1994 and 1995, as a first step in conducting the Upper Colorado River Basin investigation, already-existing water-related publications and data for the basin were compiled and organized. A computerized literature search was done to identify many of the publications that would be useful in the water-quality assessment of the basin. In addition, Federal, State, and local government agencies and private organizations working, or having an interest, in the study unit were contacted regarding their knowledge or possession of water-related publications and data for the basin.

\section{Purpose and Scope}

This report presents a bibliography, coauthor and subject indices, and data sources of waterrelated information and publications for the Upper Colorado River Basin in Colorado and Utah and is a centralized source for this information. The bibliographic part of the report is a comprehensive collection of approximately 1,400 references on water-related studies conducted in the Upper Colorado River Basin. Journal articles, published reports and books, unpublished master's theses and doctoral dissertations, conference proceedings, book reviews, approved in-press publications, and maps dating from 1872 through February 1995 are referenced. Unpublished manuscripts are not included. For some bibliographic citations, abstracts have been provided.

The listing of water-related data sources for the Upper Colorado River Basin includes information on surface- and ground-water hydrology and aquatic biology. The hydrologic data consist of streamflow and diversion records; water-quality information on inorganics, organics, pesticides, salinity, and trace metals; water-level records; and well data. The aquatic-biology sources provide information on algae, fish, and invertebrates in the basin.

\section{Description of Study Unit}

The Upper Colorado River Basin study unit includes parts of the States of Colorado and Utah. More than 99 percent of the approximately 17,800 square-mile drainage area is located in Colorado (fig. 1). The main stem of the Colorado River originates in the mountains of central Colorado and flows about 230 miles southwest into Utah. The major tributaries to this part of the Colorado River are the Blue, Eagle, Roaring Fork, and Gunnison Rivers (fig. 1). These tributaries also originate in the mountainous eastern and southern parts of the study unit that are bounded by the Continental Divide.

The two-State study unit is largely rural and has a population of about 234,000 people (Bureau of Census, 1991), most of whom reside in Colorado. The majority of the population in the basin is concentrated in the Grand Junction, Colorado, area. Population fluctuates during the year as a result of tourism, a major year-round industry in the basin, and large increases in population occur during the summer and winter.

Most of the mountainous regions in the study unit have been set aside specifically for recreational activities. In the river valleys and on the plateaus, irrigated agriculture is the principal land use. Mining was the first major industry in the study unit and still is an important industry in some locations. Urban land use, presently (1995) a small land-use category in the study unit, is increasing as a result of people moving from more densely urbanized areas of the country to the less densely urbanized mountain areas in the West. 


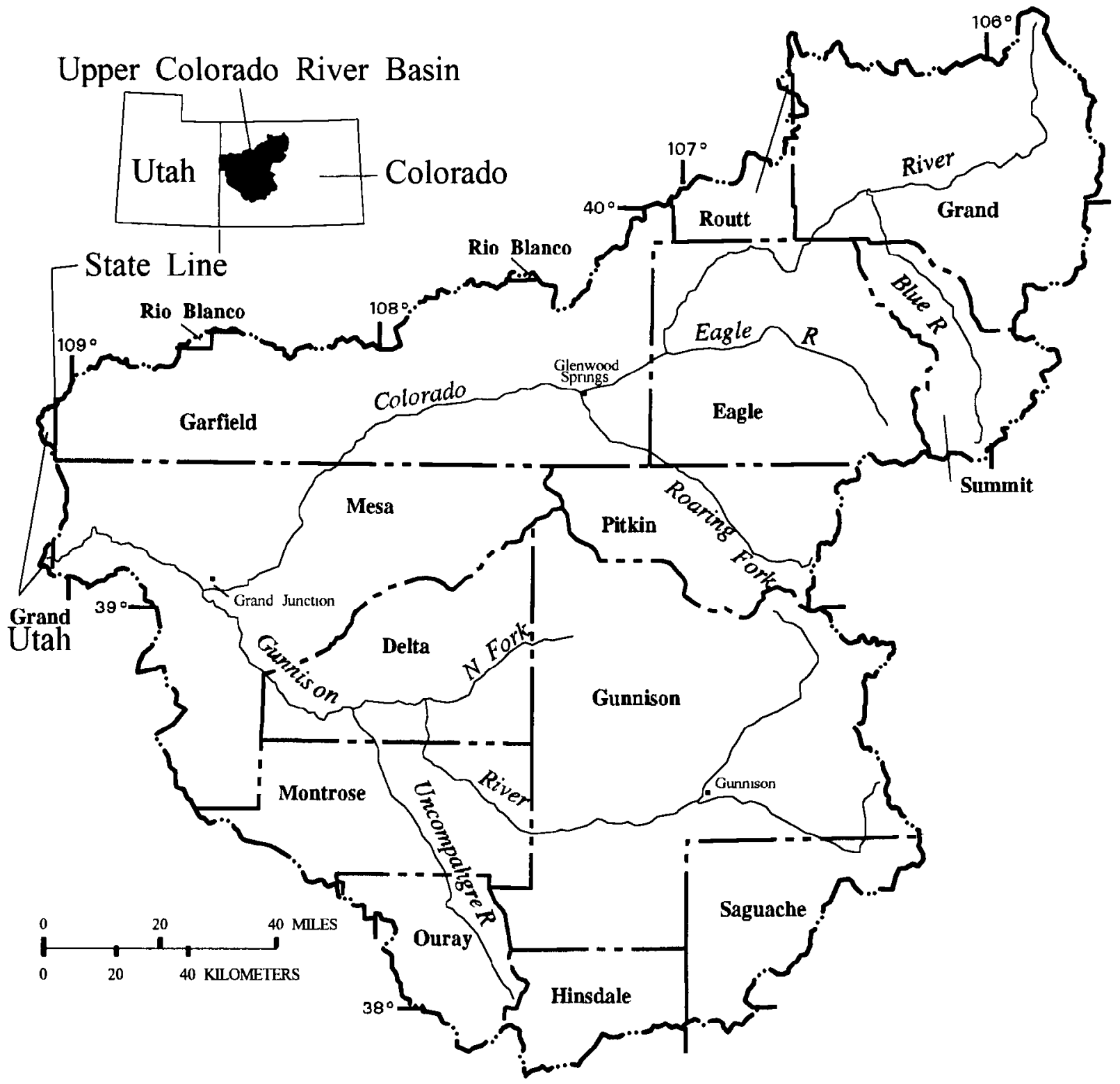

Figure 1. Location of the Upper Colorado River Basin study unit. 


\section{Sources of Water-Related Information}

A computerized literature search for water-related studies about the Upper Colorado River Basin was conducted on selected scientific data bases through the online DIALOG service of Knight-Ridder Information, Inc., Mountain View, California. DIALOG is a collection of over 450 data bases covering a wide range of disciplines and topics. The 21 data bases searched for the study unit and their relevant descriptive information are listed in table 1 . The online search was performed using keywords that consist of a combination of broad and specific hydrologic names and terms (fig. 2).

To supplement the computerized retrieval, the following agencies supplied information on waterrelated publications that might not have been cited in the 21 data bases searched:

Agricultural Research Service, Fort Collins, Colorado

Colorado Department of Public Health and Environment, Denver, Colorado

Colorado Division of Wildlife, Denver, Colorado

Colorado Division of Wildlife, Regional Office and Research Center, Fort Collins, Colorado

Colorado Water Resources Research Institute, Fort Collins, Colorado

Denver Water Department, Denver, Colorado

National Park Service, Curecanti National Recreation Area, Gunnison, Colorado

National Park Service, Rocky Mountain Regional Office, Denver, Colorado

Upper Gunnison River Water Conservancy District, Gunnison, Colorado

U.S. Department of Energy, Uranium Mill Tailings Remedial Action Project, Albuquerque, New Mexico

U.S. Environmental Protection Agency, National Enforcement Investigations Center Library, Denver, Colorado

U.S. Fish and Wildlife Service, Grand Junction, Colorado

U.S. Geological Survey, Central Region Library, Denver, Colorado

U.S. Geological Survey, Colorado Water Resources Library, Denver, Colorado 
Table 1. List of data bases searched for water-related studies about the Upper Colorado River Basin study unit

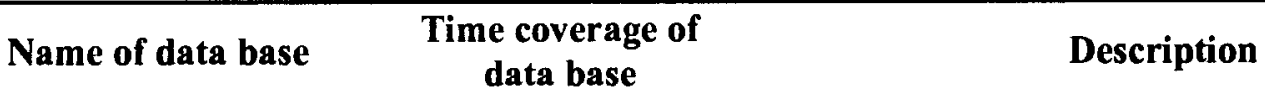

Aquatic Sciences and

Fisheries Abstracts

BIOSIS Previews

CA Search

CAB Abstracts

Conference Papers Index

Dissertation Abstracts Online

Ei Compendex* Plus

Enviroline

Environmental Bibliography

FLUIDEX (Fluid

Engineering Abstracts)

GeoArchive

GEOBASE

GeoRef
1979 to 1994

1969 to 1994

1967 to 1993

1972 to 1993

1973 to 1994

1861 to 1994

1970 to 1994

1970 to 1993

1974 to 1993

1973 to 1994

1974 to 1994

1980 to 1994

1785 to 1994
Comprehensive data base on the science, technology, and management of marine and freshwater environments

Comprehensive worldwide coverage of research in the biological and biomedical sciences

Indexing data base on chemistry and its applications

Comprehensive data base of agricultural and biological information

Centralized source of information on reports of research and development from papers presented at conferences and meetings

Indexing data base of all American dissertations accepted at accredited institutions

Indexing data base on engineering and technology

Indexing and abstracting data base covering all aspects of the environment

Bibliographic data base covering the fields of human ecology, atmospheric studies, energy, land resources, water resources, and nutrition and health

Indexing and abstracting data base for literature on every aspect of fluid engineering

Comprehensive data base covering the geosciences

Comprehensive data base providing worldwide coverage on geography, geology, ecology, and their related disciplines

Indexing earth science data base covering worldwide technical literature on geology and geophysics 
Table 1. List of data bases searched for water-related studies about the Upper Colorado River Basin study unit--Continucd

\begin{tabular}{|c|c|c|}
\hline Name of data base & $\begin{array}{l}\text { Time coverage of } \\
\text { data base }\end{array}$ & Description \\
\hline Life Sciences Collection & 1978 to 1993 & $\begin{array}{l}\text { Abstracting data base providing worldwide coverage of } \\
\text { life sciences including animal behavior, ecology, and } \\
\text { toxicology }\end{array}$ \\
\hline $\begin{array}{l}\text { NTIS (National Technical } \\
\text { Information Service) }\end{array}$ & 1964 to 1994 & $\begin{array}{l}\text { National Technical Information Service data base of } \\
\text { government-sponsored research, development, and } \\
\text { engineering reports }\end{array}$ \\
\hline Pascal & 1973 to 1993 & $\begin{array}{l}\text { Multidisciplinary indexing and abstracting data base that } \\
\text { includes biology, chemistry, earth sciences, energy, food } \\
\text { and agricultural sciences, life sciences, and pollution }\end{array}$ \\
\hline Pollution Abstracts & 1970 to 1994 & $\begin{array}{l}\text { Indexing data base of environmental-related literature on } \\
\text { pollution, its sources, and its control }\end{array}$ \\
\hline SciSearch & 1974 to 1994 & $\begin{array}{l}\text { Multidisciplinary index to the literature of science and } \\
\text { technology }\end{array}$ \\
\hline Water Resources Abstracts & 1968 to 1994 & $\begin{array}{l}\text { Indexing and abstracting data base that includes } \\
\text { ground- and surface-water hydrology; water- } \\
\text { resources economics, planning, and management; and } \\
\text { water-related aspects of nuclear radiation and safety }\end{array}$ \\
\hline WATERNET & 1971 to 1993 & Comprehensive index of water and wastewater publications \\
\hline Zoological Record Online & 1978 to 1993 & $\begin{array}{l}\text { Online data base that provides worldwide coverage of } \\
\text { zoological literature }\end{array}$ \\
\hline
\end{tabular}




\section{KEYWORDS}

\section{COUNTIES}

\begin{tabular}{|ll|}
\hline Delta & Montrose \\
Eagle & Ouray \\
Garfield & Pitkin \\
Grand (Colo.) & Routt \\
Gunnison & Saguache \\
Hinsdale & Summit \\
Mesa & \\
\hline
\end{tabular}

HYDROLOGIC UNITS

\begin{tabular}{|lll|}
\hline Blue River & Highline Canal & Roaring Fork River \\
Colorado River & Leadville Limestone & Rock Creek \\
Crystal River & Main Elk Creek & Smith Fork \\
Eagle River & Muddy Creek & Taylor River \\
East River & Parachute Creek & Tomichi Creek \\
Escalante River & Piney River & Uncompahgre River \\
Fraser River & Plateau Creek & Williams Fork \\
Gunnison River & Roan Creek & \\
& & \\
& & \\
\hline Aquatic Biology & LPECIFIC TERMS & Water Chemistry \\
Climate & Limnology & Water Management \\
Fish Populations & Riparian Habitats & Water Pollution \\
Ground Water & Stream Sediment & Water Quality \\
Hydrology & Surface Water & Water Use \\
& Urban Runoff & \\
\hline
\end{tabular}

Figure 2. Keywords used in computerized retrieval of water-related studies from DIALOG data bases. 
Additional references were identified by searching published bibliographies on the biology, geology, and hydrology of the Upper Colorado River Basin (Joseph, 1977; Wydoski and others, 1980; Banta and Lane, 1992). Banta and Lane (1992), in particular is a comprehensive bibliography and index on ground-water hydrology and geology of Colorado west of the Continental Divide and is an excellent resource for detailed information on hydrogeology in the Upper Colorado River Basin study unit. Other bibliographic literature pertaining to the study unit includes a series of comprehensive reports on Colorado geology (American Geological Institute, 1976; 1983 a, b; 1987; 1990), geothermal reports in Colorado (Pearl and others, 1981), and limnology and fishery biology of Colorado (Olive, 1953). A complete listing of bibliographies applicable to the study unit can be obtained by referencing "bibliography" in the subject index of this report.

Government agencies and private organizations were contacted by telephone in 1994 for information on the availability of water-related data on the Upper Colorado River Basin, including water-quality data for surface- and ground-water and aquatic-biology data. Information collected included: type of data available, storage mechanism (paper or digital), and general location of water body. The sources of water-related data for the study unit are listed in table 2 .

\section{Arrangement of References}

References are listed alphabetically by principal author, either individual or corporate, and are numbered consecutively. A few reference numbers have been skipped due to editing, and additional references identified late in the review process have been added at the end of the alphabetical listing. Every effort has been made to ensure that all references in this bibliography are correct. However, because the bibliography is the result of a computerized search of reference data bases, some citations might be incomplete or might contain errors. Not all references could be checked or verified. In some instances, the cited reference might not meet U.S. Geological Survey standards for publication of references. Where possible, abstracts were downloaded along with the references and included in the bibliography. Since the abstracts are considered direct quotes, no attempt was made to edit the abstracts. Terminology and abbreviations might be inconsistent between abstracts.

Coauthor and subject indices are located at the back of this report. The numbers following the index entries correspond to the reference numbers in the bibliographic section. Subject-index terms were chosen from a thesaurus prepared by the Office of Water Research and Technology (1980). Additional terms were added by the authors to facilitate the finding of a given reference. 
Table 2. Sources of water-related data for the Upper Colorado River Basin study unit

\begin{tabular}{ccc}
\hline $\begin{array}{c}\text { Organization name, mailing address, } \\
\text { telephone number }\end{array}$ & $\begin{array}{c}\text { Type and form of data available } \\
(\mathrm{P}, \text { paper; } \mathrm{D} \text {, digital) }\end{array}$ & General location \\
\hline
\end{tabular}

Bureau of Reclamation

P.O. Box 60340

Grand Junction, CO 81506

(970) 241-9371

City of Aurora

1470 South Havana St., Suite 400

Aurora, CO 80012

(303) 695-7460

City of Grand Junction

250 North 5th Street

Grand Junction, CO 81501

(970) 244-1509

Clifton Water District

P.O. Box 100

137 Third St.

Clifton, CO 81520

(970) 434-7328

Colorado Department of Natural Resources

Division of Minerals and Geology

1313 Sherman St., Room 215

Denver, $\mathrm{CO} 80203$

(303) 866-3567

Colorado Department of Natural Resources

Division of Water Resources

Office of the State Engineer

1313 Sherman St., Room 818

Denver, CO 80203

(303) 866-3581

Colorado Department of Natural Resources

Division of Wildlife

6060 Broadway

Denver, CO 80216

(303) 297-1192

Colorado Department of Natural Resources

Soil Conservation Board

1313 Sherman St., Room 219

Denver, CO 80203

(303) 866-3351
Surface- and ground-water quality

(field parameters, major ions, and trace

elements): P, D

Surface-water quality: $\mathbf{P}$

Surface-water quality (field

parameters, major ions, trace elements,

and volatile organic compounds): D

Surface-water quality (field

parameters, major ions, and trace

elements): D

Surface-water quality at active coal

mine areas: $P$

Surface-water, surface-

drainage, and well data: $P$

Surface-water quality: P, D

Ground water (field parameters, major ions, trace elements, lithologic logs,

and water levels): P, D

Diversion records: $\mathrm{P}, \mathrm{D}$

Streamflow records: P, D

Surface-water quality and aquatic

biology: $P$

Surfacc-watcr quality (field parameters and trace elements) and aquatic

biology: P

Nonpoint source assessments for salinity: P
Grand and Uncompahgre

Valleys and Lower

Gunnison River Basin

Upper Eagle River tributaries (Cross and Homestake Creeks)

Gunnison River and

Colorado River

Colorado River near Grand Junction

Upper Colorado River Basin

Upper Colorado River Basin

Upper Colorado River Basin

Upper Colorado River Basin

Eagle River

Upper Colorado River Basin 
Table 2. Sources of water-related data for the Upper Colorado River Basin study unit--Continued

\begin{tabular}{ccc}
\hline $\begin{array}{c}\text { Organization name, mailing address, } \\
\text { telephone number }\end{array}$ & $\begin{array}{c}\text { Type and form of data available } \\
(\mathrm{P}, \text { paper; } \mathrm{D}, \text { digital) }\end{array}$ & General location \\
\hline
\end{tabular}

Colorado Department of Public Health and Environment

4300 Cherry Creek Drive South

Denver, CO 80222-1530

(303) 692-2000

Colorado River Decision Support System

Colorado Water Conservation Board

1313 Sherman St., Room 721

Denver, CO 80203

(303) 866-3441

Denver Water Department

1600 West 12 th Avenue

Denver, CO 80254

(303) 692-6000

National Park Service

1201 Oak Ridge Drive, Ste. 250

Fort Collins, CO 80525

(970) 225-3501

National Park Service

Curecanti National Recreation Area

102 Elk Creek

Gunnison, CO 81230

(970) 641-2337

Northwest Colorado Council of

Governments

P.O. Box 2308

Silverthorne, CO 80498

(970) 468-0295

U.S. Department of Agriculture

Agricultural Research Service

AERC-CSU

Fort Collins, CO 80523

(970) 491-8511
Surface-water quality (field parameters, major ions, nutrients, and trace ele-

ments), ground-water quality (field

parameters, major ions, nutrients, pesti-

cides, and trace elements), and aquatic

biology: P, D

Surface- and ground-water quality (field parameters and trace elements): $P$

Monthly streamflow data and reservoir characteristics: D

Surface-water quality: D

Surface-water quality: P, D

Stream and reservoir water-quality monitoring (field parameters and major ions) and aquatic biology: P, D

Water-quality management plan: $\mathbf{P}$

Salinity from irrigation: $P$

Crop water use: $\mathbf{P}$
Upper Colorado River Basin

Eagle Mine site on Eagle River

Colorado River Basin and Gunnison River Basin

Blue River and Snake River upstream from Dillon Reservoir, Williams Fork, and Fraser River

Rocky Mountain National Park, Curecanti National Recreation Area, and Black Canyon of the Gunnison National Monument

Upper Gunnison River Basin

Eagle, Grand, Jackson, Pitkin, Routt, and Summit Counties

Grand Valley and Upper Gunnison River Basin 
Table 2. Sources of water-related data for the Upper Colorado River Basin study unit--Continued

\begin{tabular}{|c|c|c|}
\hline $\begin{array}{l}\text { Organization name, mailing address, } \\
\text { telephone number }\end{array}$ & $\begin{array}{l}\text { Type and form of data available } \\
\text { (P, paper; } D \text {, digital) }\end{array}$ & General location \\
\hline $\begin{array}{l}\text { U.S. Department of Agriculture } \\
\text { Natural Resources Conservation Service } \\
655 \text { Parfet Street, Room E200C } \\
\text { Lakewood, CO } 80215 \\
\text { (303) 236-2886 }\end{array}$ & $\begin{array}{l}\text { Monitoring and evaluating for the } \\
\text { Colorado River Salinity Control } \\
\text { Program: P }\end{array}$ & Grand Valley \\
\hline $\begin{array}{l}\text { U.S. Department of Energy } \\
\text { (UMTRA) } \\
\text { P.O. Box } 5400 \\
\text { Albuquerque, NM } 87185-5400 \\
\text { (505) 845-5657 }\end{array}$ & $\begin{array}{l}\text { Surface- and ground-water quality } \\
\text { (field parameters, major ions, } \\
\text { radionuclides, and trace elements): P, } \\
\text { D }\end{array}$ & $\begin{array}{l}\text { Old Rifle, New Rifle, } \\
\text { Gunnison, and Grand } \\
\text { Junction uranium mill } \\
\text { tailings sites }\end{array}$ \\
\hline $\begin{array}{l}\text { U.S. Fish and Wildlife Service } \\
764 \text { Horizon Drive } \\
\text { South Annex A } \\
\text { Grand Junction, CO } 81506 \\
\text { (970) 243-2778 }\end{array}$ & Aquatic biology: $P$ & Upper Colorado River Basin \\
\hline $\begin{array}{l}\text { U.S. Geological Survey } \\
\text { Water Resources Division } \\
\text { Colorado District Office } \\
\text { P.O. Box 25046, Mail Stop } 415 \\
\text { Denver, CO 80225-0046 } \\
\text { (303) 236-4882 }\end{array}$ & $\begin{array}{l}\text { Surface-water quality and quantity } \\
\text { (field parameters, major ions, nutrients, } \\
\text { trace elements, and discharge) and } \\
\text { ground-water quality and quantity } \\
\text { (field parameters, major ions, nutrients, } \\
\text { trace elements, lithologic logs, and } \\
\text { water levels): P, D }\end{array}$ & $\begin{array}{l}\text { Colorado (National Water } \\
\text { Information System files) }\end{array}$ \\
\hline $\begin{array}{l}\text { U.S. Geological Survey } \\
\text { Water Resources Division } \\
\text { Wayne Aspinall Federal } \\
\text { Building, Room } 223 \\
402 \text { Rood Avenue } \\
\text { Grand Junction, CO } 81501 \\
\text { (970) 245-5257 }\end{array}$ & $\begin{array}{l}\text { Irrigation drainage studies: surface- } \\
\text { water quality and quantity (field } \\
\text { parameters, major ions, nutrients, trace } \\
\text { elements, and discharge), ground-water } \\
\text { quality and quantity (field parameters, } \\
\text { major ions, nutrients, trace elements, } \\
\text { and water levels), and aquatic biology: } \\
\text { P, D }\end{array}$ & $\begin{array}{l}\text { Lower Gunnison River } \\
\text { Basin and Grand Valley }\end{array}$ \\
\hline
\end{tabular}




\section{Acknowledaments}

The authors thank April Kobayashi, Colorado District Librarian (U.S. Geological Survey, Colorado Water Resources Library), for conducting the DIALOG search of the 21 reference data bases and downloading the resulting citations and abstracts. We also thank Joyce Dickey, Library Technician, for her assistance in locating and in answering many questions on source materials. Numerous Federal, State, and local government agencies and private organizations contributed information for the bibliography and data sources, and the authors also thank them. We would particularly like to thank Janet Wise, National Park Service, for providing a comprehensive collection of references on the Gunnison River and additional references on the Colorado River system.

\section{REFERENCES CITED IN INTRODUCTION}

American Geological Institute, comp., 1976, 1983a, Bibliography and index of Colorado geology:

Denver, Colorado Geological Survey Bulletins. Bulletins as follows: 1976, 1875 to 1975, Bulletin 37, 488 p.; 1983, 1975-1980, Bulletin 45, 294 p.

1983b, 1987, 1990, Bibliography and index of Colorado geology: Denver, Colorado Geological Survey Information Series. Series as follows: 1983, 1981-1982, Information Series 19, 595 p.; 1987, 1983, Information Series 21, 127 p.; 1990, 1984-1989, Information Series 30, 584 p.

Banta, E.R., and Lane, T.J., 1992, Bibliography, index, and data sources for ground-water hydrology and geology of Colorado west of the Continental Divide: U.S. Geological Survey Open-File Report 92-79, 214 p.

Bureau of Census, 1991, 1990 census of population and housing: Washington, D.C., Bureau of Census. [Data on CD-ROM.]

Joseph, T.W., 1977, Annotated bibliography of natural resource information, northwestern Colorado: U.S. Fish and Wildlife Service Report FWS/OBS-77/35, 184 p.

Office of Water Research and Technology, 1980, Water resources thesaurus (3d ed.): U.S. Department of the Interior Office of Water Research and Technology Report OWRT IT-80/1, various pagination.

Olive, J.R., 1953, A bibliography of the limnology and fishery biology of Colorado: Denver, Colorado Department of Game and Fish, $37 \mathrm{p}$.

Pearl, R.H., Zacharakis,T.G., Repplier, F.N., and McCarthy, K.P., 1981, Bibliography of geothermal reports in Colorado: Denver, Colorado Geological Survey Bulletin 44, 24 p.

Wydoski, R.S., Gilbert, K., Seethaler, K., McAda, C.W., and Wydoski, J.A., 1980, Annotated bibliography for aquatic resource management of the Upper Colorado River ecosystem: U.S. Fish and Wildlife Service Resource Publication 135, 186 p. 


\section{BIBLIOGRAPHY}

1. Aaronson, M.J., 1982, Testing of water quality for inorganics and heavy metals for the National Park Service: Fort Collins, Colo., Colorado State University, Colorado Epidemiological Pesticide Studies Center.

2. Aaronson, M.J., 1982, Testing of water quality for total dissolved solids, radiation, and chlorinated hydrocarbon pesticides for the National Park Service: Fort Collins, Colo., Colorado State University, Colorado Epidemiological Pesticide Studies Center.

3. Abbey, D., 1979, Energy production and water resources in the Colorado River Basin: Natural Resources Journal, v. 19, no. 2, p. 275-314.

4. Abbey, D., 1979, Water supply/demand alternatives for electric generation in the Colorado Basin: Los Alamos, N. Mex., Los Alamos Scientific Laboratory, 19 p. [Available from National Technical Information Service, Springfield, VA 22161 as NTIS Report LA-7662-MS.]

Energy development in the western states, particularly the Colorado River Basin, poses two water-related concerns: that water availability may constrain development and that industrial water use may have a negative impact on other water users. Water use for electricity generation in the Colorado Basin is examined. Substitution of dry cooling for wet cooling can almost eliminate the consumptive use of water at an electric plant. The cost of water saved, however, is quite high compared to the cost of water supply alternatives such as water transfers and groundwater and waste water use. Water use plans of utilities in the region reflect both an incentive for surface water conservation and the high cost of dry cooling. Considering that dry cooling adds a small amount to the cost of generating electricity, one may conclude that water availability has an insignificant effect on the potential for development. Although detailed evaluation of the impacts on water resources is beyond the scope of this paper, it is suggested that these concerns may be exaggerated.

5. Abbey, D., and Olinger, C., 1979, A survey of energy projects and instream resources in the Upper Colorado and Upper Missouri River Basins: Los Alamos, N. Mex., Los Alamos Scientific Laboratory, 24 p. [Available from National Technical Information Service, Springfield, VA 22161 as NTIS Report LA-8126-MS.]

Western energy production is certain to affect fisheries, recreation, aesthetic values, and water quality. Specification of these effects requires analysis of individual stream reaches. This report directs energy-related assessments to the most valuable and critical stream reaches. Section I identifies reaches in the Rocky Mountain/Northern Great Plains Region with high quality instream resources and energy projects in the vicinity or upstream from those reaches. Part A of Section II reviews methodologies for assessing streamflow modifications; Part B reviews legal aspects of streamflow protection - state water law and federal environmental legislation. The final section draws limited conclusions concerning the impacts of and constraints on energy development. 
6. Ackerman, D.J., and Brooks, Tom, 1986, Reconnaissance of ground-water resources in the North Fork Gunnison River Basin, southwestern Colorado: U.S. Geological Survey WaterResources Investigations Report 85-4230, 21 p.

7. Adams, D.B., Goddard, K.E., Patt, R.O., and Galyean, K.C., 1986, Hydrologic data from Roan Creek and Parachute Creek Basins, northwestern Colorado: U.S. Geological Survey Open-File Report 83-859, 115 p.

8. Adams, V.D., and Lamarra, V.A., eds., 1983, Aquatic resources management of the Colorado River ecosystem, proceedings of the 1981 symposium, Las Vegas, Nevada, November 16-18, 1981: Ann Arbor, Mich., Ann Arbor Science Publishers, 688 p.

This is the first comprehensive work to deal with the multitudinous problems of the present and potential uses of the Colorado River ecosystem. The authors provide the framework for the exchange of state-of-the-art information and ideas between resources managers and scientists so that this valuable resource can be successfully managed for a majority of beneficial uses. Features: water quality and quantity, modeling aquatic systems, water augmentation, and economic evaluations. Current and projected effects of water and land management practices within the Colorado River Basin are examined in detail. Initial improvements are spelled out for the management of the physical, chemical, and biological aquatic resources within the total context of activities affecting the Colorado River. Practical guidance of total river management is a combination of several factors. This new book shows how hydrologic and institutional perspectives must be combined with understanding of riverine and lacustrine aquatic systems.

9. Adamus, P.R., 1993, Irrigated wetlands of the Colorado Plateau--Information synthesis and habitat evaluation method: Corvallis, Oreg., Corvallis Environmental Research Laboratory EPA/600/R-93/071, 100 p. [Available from National Technical Information Service, Springfield, VA 22161 as NTIS Report PB-93 186 260.]

Wetlands of the Colorado Plateau receiving water from irrigation can support several societal values. However, relatively little research has been conducted in irrigated wetlands, and their ability to alter water quality in particular remains relatively unknown. For an explicit, integrated, local-scale approach to biodiversity assessment, the report introduces a new procedure for rapidly evaluating wetland and riparian habitat. The procedure estimates the number of species likely to occur regularly in a particular wetland and uses this to assign importance to the wetland. The user can employ the procedure to evaluate a wetland using any subset of species and to select combinations of wetlands that will maximize avian diversity at local and regional scales.

10. Advanced Aquatic Technology Associates, Inc., 1990, Draft Williams Fork River water quality study and Fraser River water quality study, prepared for Denver Water Department: Fort Collins, Colo., Advanced Aquatic Technology Associates, Inc.

11. Agricultural Research Service and U.S. Salinity Laboratory, 1976, Alleviation of salt load in irrigation water return flow of the Upper Colorado River Basin: Fort Collins, Colo. and Riverside, Calif., Fiscal Year 1976 annual progress report to the Bureau of Reclamation under contract \#14-06-400-5942. [Also published for Fiscal Year 1975 and Fiscal Year 1974.] 
12. Aherns, T.P., 1950, Groundwater investigation, Granby Pump Canal, Colorado Big Thompson Project, Colorado: Bureau of Reclamation.

13. Alley, W.M., Bauer, D.P., Veenhuis, J.E., and Brennan, R., 1979, Hydrologic effects of annually diverting 131,000 acre-feet of water from Dillon Reservoir, central Colorado: U.S. Geological Survey Water-Resources Investigations 79-2, 17 p. [Available from National Technical Information Service, Springfield, VA 22161 as NTIS Report ADA-072 555.]

Because of the increased demands for water in eastern Colorado, principally in the urbanizing Denver metropolitan area, increased diversions of water from Dillon Reservoir are planned. Estimates of end-of-month storage in Dillon Reservoir, assuming the reservoir was in place and 131,000 acre-feet of water were diverted from the reservoir each year, were reconstructed by mass balance for the 1931-77 water years. Based on the analysis, the annual maximum end-of-month drawdown below the elevation at full storage would have averaged 54 feet. The maximum end-ofmonth drawdown below the elevation at full storage would have been 171 feet. The mean-annual discharge-weighted dissolved-solids concentrations in the Colorado River near Glenwood Springs and Cameo, Colo., and Cisco, Utah, for the 1942-77 water years, were computed assuming an annual diversion of 131,000 acre-feet of water from Dillon Reservoir. The average increases in the dissolved-solids concentrations with the 131,000 acre-foot diversion were 15 to 16 milligrams per liter at the three sites.

14. Alley, W.M., Britton, L.J., and Boyd, E.L., 1978, Reconnaissance evaluation of water resources for hydraulic coal mining, Crested Butte Coal Field, Gunnison County, Colorado: U.S. Geological Survey Open-File Report 78-938, 23 p.

15. Alley, W.M., Britton, L.J., and Boyd, E.L., 1978, Reconnaissance evaluation of water resources for hydraulic coal mining, Grand Hogback Coal Field, Garfield and Rio Blanco Counties, Colorado: U.S. Geological Survey Open-File Report 78-885, 37 p.

16. American Geological Institute, comp., 1976, 1983a, Bibliography and index of Colorado geology: Denver, Colo., Colorado Geological Survey Bulletins. Bulletins as follows: 1976, 1875 to 1975, Bulletin 37, 488 p.; 1983, 1975-1980, Bulletin 45, 294 p.

17. American Geological Institute, comp., 1983b, 1987, 1990, Bibliography and index of Colorado geology: Denver, Colo., Colorado Geological Survey Information Series. Series as follows: 1983, 1981-1982, Information Series 19, 595 p.; 1987, 1983, Information Series 21, 127 p.; 1990, 1984-1989, Information Series 30, 584 p.

18. American Geological Institute and National Park Service, 1981, Draft alternatives for the Colorado River management plan: American Geological Institute, U.S. Department of the Interior National Park Service, various pagination. 
19. Anderson, J.C., Kleinman, A.P., Brown, F.B., Cannon, J.R., and d'Arge, R.C., 1978, Salinity management options for the Colorado River, damage estimates and control program impacts: Bureau of Reclamation Report OWRT-B-107-UTAH(2), 366 p. [Available from National Technical Information Service, Springfield, VA 22161 as NTIS Report PB-285 482/6.]

Rivers draining arid basins increase salinity content in the downstream areas to the point where water users are often significantly damaged. The problem in some cases can be ameliorated by altering upstream water and land use practices. An economic trade-off exists between the cost of such upstream efforts and the downstream benefits achieved. This study sought to provide additional information to estimate (1) economic damages caused by various salt concentrations to agricultural and municipal water users and (2) economic costs of salinity control measures by upstream water users. Damages were estimated for high salinity levels to provide guidelines to project future conditions. Control costs were estimated with a physical model developed to predict the response of soil, water, and crop factors. Input-output models were used to estimate indirect economic impacts.

20. Anderson, M.S., Lakin, H.W., Beeson, K.C., Smith, F.F., and Thacker, E., 1961, Selenium in agriculture: U.S. Department of Agriculture Handbook 200, 65 p.

21. Anderson, R.L., 1967, Windfall gains from transfer of water allocations within the ColoradoBig Thompson Project: Land Economics, v. XLIII, no. 3, p. 265-273.

22. Andrews, E.D., Johnston, C.E., and Stanford, J., 1994, Historical variations and trends in water temperature in the Upper Colorado River Basin [abs.], in Marston, R.A., and Hasfurther, V.R., eds., Proceedings, annual summer symposium of the American Water Resources Association, effects of human-induced changes on hydrologic systems, Jackson Hole, Wyoming, June 26-29, 1994: Bethesda, Md., American Water Resources Association Technical Publication Series TPS-94-3, p. 771.

23. Apley, M., 1981, Buttes Gas and Oil surface water quality study, 1979-1980: Gunnison, Colo., Western State College.

24. Apley, M., 1981, Powderhorn surface water quality study, 1980-1981: Gunnison, Colo., Western State College, $46 \mathrm{p}$.

25. Apley, M., 1982, Powderhorn surface water quality study: Gunnison, Colo., Western State College, $75 \mathrm{p}$.

26. Appel, C.L., and Butler, D.L., 1991, Effects of a landslide complex on sediment discharges and loads in the Muddy Creek drainage basin and deposition into Paonia Reservoir, west-central Colorado, 1986-87: U.S. Geological Survey Water-Resources Investigations Report 90-4173, $53 \mathrm{p}$.

27. Archer, D.L., Kaeding, L.R., Burdick, B.D., and McAda, C.W., 1985, A study of the endangered fishes of the Upper Colorado River: U.S. Fish and Wildlife Service Final Report 14-16-0006-82959. 
29. August, M.H., Jacoboni, J.M., Jeton, A.E., Parker, R.S., Pupacko, Alex, Ruddy, B.C., Smith, J.L., and Redmond, K.T., 1992, Hydrologic and climatic data bases used to assess potential effects of climate change on water resources of American River, Carson River, and Truckee River Basins, California-Nevada, and of Gunnison River Basin, Colorado: U.S. Geological Survey Open-File Report 92-627, 72 p.

30. Aurand, H.A., 1920, Mineral deposits of the Western Slope: Denver, Colo., Colorado Geological Survey Bulletin 22, 78 p.

31. Azimi-Zonooz, A., and Duffy, C.J., 1994, Modeling transport of subsurface salinity from a Mancos Shale hillslope: Ground Water, v. 31, no. 6, p. 972-981.

32. Baden, J., Fullerton, H.H., and Neuhold, J., 1974, Resource allocation and management in the Colorado River Basin, in Crawford, A.B., and Peterson, D.F., eds., Environmental management in the Colorado River Basin: Logan, Utah, Utah State University Press, p. 261-280.

33. Bagley, J.M., 1980, Potential impacts of energy development on streamflows in the Upper Colorado River Basin, a discussion, in Spofford, W.O., Jr., Parker, A.L., and Kneese, A.V., eds., Energy development in the Southwest, problems of water, fish and wildlife in the Upper Colorado River Basin, volume 1: Washington, D.C., Resources for the Future, Research Paper R-18, p. 438-447.

34. Baker, W.L., 1989, Classification of the riparian vegetation of the montane and subalpine zones in western Colorado: Great Basin Naturalist, v. 49, no. 2, p. 214.

35. Balloffet, A.F., and Hovey, G.L., 1984, Salinity studies; caring for the Colorado River: Military Engineering, v. 76, no. 492, p. 91-95.

The Bureau of Reclamation used the information from the salinity investigation of the Glenwood-Dotsero Springs Unit to select the 'West Salt Creek - DG' plan as the most desirable, because it satisfies co-equal objectives of the Colorado River Water Quality Improvement (CRWQI): maximizing salt reduction and being comparatively cost effective. More detailed evaporation pond designs, estimates, and environmental work has been completed. Authorization for the project will not be sought until other more cost-effective units of the CRWQI have been implemented. The URS Corporation was presented a 1982 Grand Award of Engineering Excellence by the American Consulting Engineers Council for its work on this project.

36. Banta, E.R., and Lane, T.J., 1992, Bibliography, index, and data sources for ground-water hydrology and geology of Colorado west of the Continental Divide: U.S. Geological Survey Open-File Report 92-79, 214 p.

37. Bargsten, G., Skogerboe, G.V., and Walker, W.R., 1974, Grand Valley, an environmental challenge: Fort Collins, Colo., Colorado State University, 23 p. 
38. Barnett, J.A., 1985, Hydropolitical solutions to complex nonpoint salinity pollution problems in the Colorado River Basin, in Perspectives on nonpoint source pollution, proceedings of a national conference, Kansas City, Missouri, May 19-22, 1985: Washington, D.C., U.S. Environmental Protection Agency, p. 273.

Two countries and seven States have worked through a maze of conflicting interests in the Colorado River so that water resources may be used, additional water resources may be developed, and water quality can be protected. The current success of these long and extended negotiations should be judged as almost a political miracle. Most recently, cost sharing for the treatment of nonpoint source agricultural return flows has been agreed to. By compact and treaty, the waters of the Colorado River have been divided among the upper and lower basin States and between Mexico and the United States. Additional water resource development is anticipated in the future.

Previously, studies had indicated that the use of the waters of the Colorado over the last several decades has increased the salinity of the river in the lower reaches. It is estimated that 9 million tons of salt will reach Lake Mead each year. To maintain the salinity levels in the future, it is expected that more than approximately 1 million tons of salt a year must be removed from the river system.

39. Barnhart, R.A., 1957, Chemical factors affecting the survival of game fish in a western Colorado reservoir: Fort Collins, Colo., Colorado State University, Master's thesis, $114 \mathrm{p}$.

40. Barrett, J.K., and Pearl, R.H., 1977, An appraisal of Colorado's geothermal resources: Denver, Colo., Colorado Geological Survey Fourth Semi-Annual Final Technical Report, 290 p.

41. Barrett, J.K., and Pearl, R.H., 1978, An appraisal of Colorado's geothermal resources: Denver, Colo., Colorado Geological Survey Bulletin 39, 224 p.

42. Barrett, J.K., and Pearl, R.H., 1993, Hydrogeochemical data of thermal springs and wells in Colorado: Denver, Colo., Colorado Geological Survey Information Series 6, 124 p.

43. Barrett, J.K., Pearl, R.H., and Pennington, A.J., 1976, Map showing thermal springs, wells and heat-flow contours in Colorado: Denver, Colo., Colorado Geological Survey Information Series 4.

44. Barrows, P.T., 1956, Forest Lake marked fish studies: Denver, Colo., Colorado Department of Game, Fish, and Parks, 37 p.

45. Barton, H.N., 1985, Geochemical maps showing the distribution and abundance of selected elements in heavy-mineral concentrates of stream sediments from Vasquez Peak Wilderness Study Area and the Williams Fork and St. Louis Peak Roadless Areas, Clear Creek, Grand, and Summit Counties, Colorado: U.S. Geological Survey Miscellaneous Field Studies Map MF1588-G, 2 sheets, scale 1:100,000.

46. Barton, H.N., and Turner, R.L., 1984, Geochemical data for the Vasquez Peak Wilderness Study Area (A2361), the Williams Fork Further Planning Area (2-114), and the St. Louis Peak Roadless Area (F2361), Clear Creek, Grand, and Summit Counties, Colorado: U.S. Geological Survey Open-File Report 84-505, 53 p.; 2 sheets, scale 1:24,000; 1 sheet, scale 1:100,000. 
47. Battaglin, W.A., Hay, L.E., Parker, R.S., and Leavesley, G.H., 1993, Application of a GIS for modeling the sensitivity of water resources to alterations in climate in the Gunnison River Basin, Colorado, in Harlin, J.M., and Lanfear, K.J., eds., Proceedings of the symposium on geographic information systems and water resources, March 14-17, 1993, Mobile, Alabama: Bethesda, Md., American Water Resources Association Technical Publication Series TPS-93-1, p. 203-210.

48. Bauman, R.W., Gaufin, A.R., and Surdick, R.F., 1977, The stoneflies (Plecoptera) of the Rocky Mountains: American Entomological Society Memoirs, v. 31, p. 1-208.

49. Bechtel Corporation and Ecology Consultants, Inc., 1975, Environmental baseline program 1974-1975--Oil shale prototype development, Parachute Creek: Union Oil Company of California, 293 p.

50. Beckman, W.C., 1952, A guide to the fishes of Colorado: Boulder, Colo., University of Colorado Museum Leaflet 11. [Also published in 1952 under the same title by the Colorado Department of Game and Fish, Denver, Colo., 110 p.l

51. Behnke, R.J., 1980, The impacts of habitat alterations on the endangered and threatened fishes of the Upper Colorado River Basin, in Spofford, W.O., Jr., Parker, A.L., and Kneese, A.V., eds., Energy development in the Southwest, problems of water, fish and wildlife in the Upper Colorado River Basin, volume 2: Washington, D.C., Resources for the Future, Research Paper R-18, p. 204-216.

52. Behnke, R.J., 1985, Fisheries impact analysis for year-round flow depletion of $1000 \mathrm{cfs}$ from Gunnison River in Black Canyon area: Fort Collins, Colo., Colorado State University.

53. Behnke, R.J., 1986, Potential impacts of reduced winter flows in Gunnison River on trout reproduction and growth in relation to lower temperatures and ice formation: Fort Collins, Colo., Colorado State University.

54. Behnke, R.J., and Benson, D.E., 1980, Endangered and threatened fishes of the Upper Colorado River Basin: Fort Collins, Colo., Colorado State University Cooperative Extension Service Bulletin 503A, 34 p.

55. Behnke, R.J., and Benson, D.E., 1983, Endangered and threatened fish species in the Upper Colorado River as related to Bureau of Reclamation projects: Salt Lake City, Utah, Bureau of Reclamation, $36 \mathrm{p}$.

56. Beidleman, R.G., 1959, The Gunnison River diversion project: Colorado Magazine--The State Historical Society of Colorado, v. 36, no. 3, p. 187-210, 266-285.

57. Beidleman, R.G., 1963, The Black Canyon of the Gunnison National Monument: Colorado Magazine--The State Historical Society of Colorado, v. 40, no. 3, p. 161-178.

58. Bencala, K.E., and McKnight, D.M., 1987, Identifying in-stream variability--Sampling iron in an acidic stream, in Averett, R.C., and McKnight, D.M., eds., Chemical quality of water and the hydrologic cycle: Chelsea, Mich., Lewis Publishers, p. 255-269.

59. Bencala, K.E., McKnight, D.M., and Zellweger, G.W., 1987, Evaluation of natural tracers in an acidic and metal-rich stream: Water Resources Research, v. 23, no. 5, p. 827-836. 
60. Bencala, K.E., McKnight, D.M., and Zellweger, G.W., 1990, Characterization of transport in an acidic and metal-rich mountain stream based on a lithium tracer injection and simulations of transient storage: Water Resources Research, v. 26, no. 5, p. 989-1000.

61. Bencala, K.E., McKnight, D.M., Zellweger, G.W., and Goad, Julie, 1986, The stability of rhodamine WT dye in trial studies of solute transport in an acidic and metal-rich stream, in Subitzky, Seymour, ed., Selected papers in the hydrologic sciences 1986: U.S. Geological Survey Water-Supply Paper 2310, p. 87-95.

62. Bencala, K.E., and Zellweger, G.W., 1988, Transport and retention of solutes in high-gradient streams--An overview of multi-tracer experimentation in the acidic Snake River, Summit County, Colorado [abs.]: EOS, American Geophysical Union Transactions, v. 69, no. 44, p. 1218-1219.

63. Benci, J.F., and McKee, T.B., 1977, Colorado monthly temperature and precipitation summary for period 1951-1970: Fort Collins, Colo., Colorado State University Climatology Report 77-1, $300 \mathrm{p}$.

64. Bentley, R.G., Jr., Eggleston, K.O., Price, D., Frandsen, E.R., and Dickerman, A.R., 1978, The effects of surface disturbances (primarily livestock use) on the salinity of public lands in the Upper Colorado River Basin--1977 status report (October 1975-December 1977): Denver, Colo., Bureau of Land Management BLM/YA/TR-78/01, 254 p. [Available from National Technical Information Service, Springfield, VA 22161 as NTIS Report PB-281 889/6.]

The prospect of increasing salinity in the Colorado River, resulting from greater use of water (agriculture and industry) and soil disturbances (livestock grazing and mineral and energy development), has prompted the Department of the Interior to study possible means of reducing salt yields from diffuse and point sources. The Bureau of Land Management, in this report, discusses the mechanisms involved in salt pickup and transport from diffuse sources on public lands, primarily from overland flow of water. The effects of common man-caused soil disturbance, primarily livestock grazing, on salt yields are discussed. Any practice which compacts or disturbs soil, reduces infiltration, and increases runoff and erosion on saline soils, will increase salt yields. Several common practices, designed to reduce erosion, were analyzed to determine their ability to control salt. The most promising alternative practices were subjected to benefit-cost analysis to determine their economic feasibility.

65. Berry, G.W., Grim, P.J., and Ikelman, J.A., 1980, Thermal springs list for the United States: Boulder, Colo., National Oceanic and Atmospheric Administration Key to Geophysical Records Documentation 12, 59 p.

66. Berthoud, E.L., 1881, Artesian wells in Colorado: Kansas City Review of Science and Industry, v. 4 , p. 536-546.

67. Bessler, M.B., 1983, Saline water use prospects-Colorado River: American Society of Civil Engineers, Journal of Irrigation and Drainage Engineering, v. 109, no. 2, p. 221-231.

68. Bessler, M.B., and Maletic, J.T., 1975, Salinity control and Federal Water Quality Act: American Society of Civil Engineers, Journal of the Hydraulics Division, v. 101, no. HY5, p. 581-594. 
69. Betzer, J.L., Swope, H.M., Remington, J.D., and Rutherford, W.H., 1956, Suitability of physical factors for beaver management in the Colorado Rockies: Denver, Colo., Colorado Department of Game and Fish Technical Bulletin 2, 32 p.

70. Bevans, H.E., 1989, Interior Province; western region, in Britton, L.J., Anderson, C.L., Goolsby, D.A., and Van Haveren, B.P., eds., Summary of the U.S. Geological Survey and U.S. Bureau of Land Management national coal-hydrology program, 1974-84: U.S. Geological Survey Professional Paper 1464, p. 53-61.

71. Binder, C.W., Bargsten, G., Mancuso, B.F., Evans, R.G., Walker, W.R., and Skogerboe, G.V., 1978, Grand Valley salinity control demonstration project--Basic field data: Fort Collins, Colo., Colorado State University, $194 \mathrm{p}$.

72. Bishop, A.B., 1977, Impact of energy development on Colorado River water quality: Natural Resources Journal, v. 17, no. 4, p. 649-671.

73. Bishop, A.B., 1978, Competition of energy development for water use in Upper Colorado River Basin: Pittsburg, Pa., American Society of Civil Engineers National Spring Convention and Continuing Education.

74. Bishop, A.B., Klemetson, S.L., Torpy, M.F., and McKee, M., 1979, Energy development vs. water quality in the Upper Colorado and Upper Missouri River Basins: Los Alamos, N. Mex., Los Alamos Scientific Laboratory, 183 p. [Available from National Technical Information Service, Springfield, VA 22161 as NTIS Report LA-7574-MS.]

This report examines the relationship between energy development and water quality in Upper Colorado and Upper Missouri River basins. To provide a background for problem assessment, the general physiographic, water resources, and water quality setting is described for each of the basins. The locations and types of energy resources and present and possible future developments are also identified relative to the water resource systems. The water quality problems and impacts from energy developments are discussed in terms of various pollutants generated by energy extraction and processing activities and the pollution transport mechanisms and pathways by which they can enter surface water and groundwater. Looking at the problem from another perspective, the report discusses the implications for energy development of the water quality aspects of legislation requirements and regulations. Many of the potential water pollution problems associated with energy development will not be results of directs discharges - for zero waste water discharge appears to be the standard for tomorrow, but rather will occur through the transport of pollutants from other processes and disposal activities. These processes and activities are less obvious contributors to water pollution problems and are therefore less likely to be controlled than waste water streams themselves. In response to water quality regulations and their ultimate objective to eliminate discharge, existing and proposed conversion plants are planning for total containment of waste water with no discharge to the stream system. The consumptive use of all water withdrawn for energy processing as a pollution control measure raises three important issues - each of which represents a potential conflict between energy developers' compliance with the legislation and western water law: (1) junior rights and water transfer; (2) the beneficial use question; and (3) the reasonable use measure of certain water quality practices. 
75. Bishop, A.B., Narayanan, R., McKee, M., and Nussbaum, M.T., 1984, Development of a comprehensive Upper Colorado River Basin model for analyzing energy development impacts: U.S. Geological Survey Report G-872(03), 118 p. [Available from National Technical Information Service, Springfield, VA 22161 as NTIS Report PB-85 157 808/XAB.]

Recent advances in detection technologies, data management and retrieval systems, and modeling capabilities have led to a large number of conceptual and applied models that are already making significant contributions to water resources management in the Colorado River Basin. The potentially useful modeling concepts and applications inventoried from agency contacts and the literature are assessed for usefulness in the context of the physical, hydrologic, water use, flood damage potential, recreation use, environmental, economic, social, and cultural characteristics of the Basin. Modeling potentials are also assessed in the context of the history of water resources development and management in the basin and water laws and institutions that have evolved for their administration. Thus, model applications are reviewed in terms of both physical needs and institutional acceptability for water management decisions that affect water allocations within and among the states and Indian tribes. The literature describing scientific and engineering studies and the model development for applications in the Colorado Basin display parallels between time trends in the values and resulting policy on water resources development prevailing in the Basin and the research conducted.

76. Bishop, A.B., and Porcella, D.B., 1980, Physical and ecological aspects of the Upper Colorado River Basin, in Spofford, W.O., Jr., Parker, A.L., and Kneese, A.V., eds., Energy development in the Southwest, problems of water, fish and wildlife in the Upper Colorado River Basin, volume 1: Washington, D.C., Resources for the Future, Research Paper R-18, p. 17-56.

77. Bittinger, M.W., 1959, Colorado's ground-water problems--Ground water in Colorado: Fort Collins, Colo., Colorado State University Agricultural Experiment Station Bulletin 504-S, 28 p.

78. Blackman, W.C., Jr., Rouse, J.V., Schillinger, G.R., and Shafer, W.H., Jr., 1973, Mineral pollution in the Colorado River Basin: Water Pollution Control Federation Research Journal, v. 45, no. 7, p. 1517-1557.

Concentration of total dissolved solids (salinity) in Colorado River basin streams are identified as a major problem for lower basin water users. Salinity concentrations in unregulated streams of the basin comprise two distinct populations that are grouped into base flow months and runoff months. Statistically significant increases in salinity have occurred with increasing water use and downstream progression.

79. Blackwelder, E., 1934, Origin of the Colorado River: Geological Society of America Bulletin, v. 45 , no. 3, p. 551-566.

80. Blackwell, R.J., and Boland, 1979, Trophic classification of selected lakes: Pasadena, Calif., Jet Propulsion Laboratory Report EPA-600/4-79-005.

81. Bliss, J.D., 1983, Colorado--Basic data for thermal springs and wells as recorded in GEOTHERM: U.S. Geological Survey Open-File Report 83-429, 176 p. 
82. Boettcher, A.J., 1971, Evaluation of the water supply at six sites in the Curecanti Recreation Area, southwestern Colorado: U.S. Geological Survey Open-File Report 71-005, 28 p.

83. Boettcher, A.J., 1972, Ground-water occurrence in northern and central parts of western Colorado: Denver, Colo., Colorado Water Resources Circular 15, 25 p.

84. Bombolakis, E.G., 1959, Geology of the Hot Sulphur Springs-Parshall area of Middle Park, Grand County, Colorado: Golden, Colo., Colorado School of Mines, Master's thesis, 146 p.

85. Booker, J.F., and Young, R.A., 1991, Economic impacts of alternative water allocation institutions in the Colorado River Basin: U.S. Geological Survey Report G-1644, 103 p. [Available from National Technical Information Service, Springfield, VA 22161 as NTIS Report PB-92 161 389/XAB.]

Colorado River water is the dominant water for much of the southwestern United States, satisfying agricultural, municipal, and industrial needs. Basin water is now fully utilized and new demands, particularly in Arizona and rapidly growing Southern California, will cause increasing pressure to reallocate basin water. Nonconsumptive uses of Colorado River water (hydropower, salinity control) physically interact with consumptive uses and are also of increasing economic significance. Water transfers would require foregoing some existing uses and would be possible only with significant institutional changes in the set of compacts, state laws, and court decisions which together control allocation of Colorado River water. The objective of the work is to evaluate policies for increasing beneficial use of basin water resources. This is achieved by estimating consumptive and nonconsumptive use benefits using a nonlinear economic optimization model employing a national perspective. Water demand sectors are linked with river flows to find allocations maximizing net economic surplus under alternative institutions. All major use sectors are integrated in an economic-hydrologic optimization model. Solutions are found under priorities governing present allocation and under increased intra- and interstate trade between existing consumptive and nonconsumptive users. Model solutions are presented using estimates of present and future economic demands under two levels of basin water flow, one representing the long-term mean, while the second simulates serious drought. Within-state water transfers are found to be particularly effective for increasing net consumptive use benefits during droughts.

86. Bowden, Charles, 1975, The impact of energy development on water resources in arid lands-Literature review and annotated bibliography (information paper): Bureau of Reclamation Report OWRT-W-189(4258)(1), 288 p. [Available from National Technical Information Service, Springfield, VA 22161 as NTIS Report PB-240 008/3.]

Water is basic to energy conversion systems, natural and man-made. Consequences of energy extraction and conversion in arid lands where water is scarce are explored. The historical past is utilized as a record for casting modern development plans into perspective; the worldwide growth in energy consumption rates is considered as the motive force behind many current energy projects in arid lands. Energy sources (coal, oil, gas, oil shale, solar energy, alternative energy sources, fission, fusion, and geothermal) are reviewed in terms of their consequences on the air, land, water, and inhabitants of such regions. Two rivers, the Colorado and the Missouri, provide small-scale models of the rewards and hazards of heavily exploiting water-short 
areas. In both instances, energy development plans, as now proposed, will seriously deplete the water supply, alter the quality of the water, land, and air, and increase the human population.

87. Bower, B.T., ed., 1977, Regional residuals environmental quality management modeling: Washington, D.C., Resources for the Future, Research Paper R-7, 230 p.

An overview of regional residuals environmental quality management (REQM) and of the analyses necessary to generate information for decisions on such management is presented. Specific topics include the objectives and content of REQM modeling; issues surrounding REQM modeling; a summary of the Lower Delaware Valley REQM model; a coordinated set of economic, hydro-salinity, and air quality models of the Upper Colorado River Basin with application to current problems; an analysis for REQM in the Ljubljana, Yugoslavia, area; a case study on using systems engineering methods in the environmental pollution research pilot area of Ostrava, Czechoslovakia; and the accomplishments of the Rotterdam session on REQM.

88. Bozek, M.A., and Rahel, F.J., 1991, Assessing habitat requirements of young Colorado River cutthroat trout by use of macrohabitat and microhabitat analysis: American Fisheries Society Transactions, v. 120, no. 5, p. 571.

89. Braithwait, C., 1974, Future directions in environmental legislation--Implications for the Colorado River Basin, in Crawford, A.B., and Peterson, D.F., eds., Environmental management in the Colorado River Basin: Logan, Utah, Utah State University Press, p. 75-81.

90. Branson, B.A., and Owen, J.B., 1970, Plant cover, runoff, and sediment yield relationships on Mancos Shale in western Colorado: Water Resources Research, v. 6, no. 3, p. 783-790.

91. Branson, E.B., 1925, Course of the Gunnison River in Colorado [abs.]: Geological Society of America Bulletin, v. 36, no. 1, p. 139.

92. Breed, C.S., 1966, A hypothesis on the age of the Colorado River [abs.]: Arizona Academy of Science Journal, v. 4, no. 1, p. 135-136.

93. Breed, C.S., 1969, A century of hypotheses on the origin of the Colorado River [abs.]: Geological Society of America Abstracts with Programs 1969, part 5, p. 9.

94. Breed, C.S., 1970, Two hypotheses of the origin and geologic history of the Colorado River, in Guidebook to Four Corners, Colorado Plateau, central Rocky Mountain region--National Association of Geology Teachers, southwest section, field conference, earth science, Cedar City, Utah, 1970: Socorro, N. Mex., New Mexico Institute of Mining and Technology, p. 31-34.

95. Brennan, R., and Grozier, R.U., 1976, Salt-load computations--Colorado River; Cameo, Colorado to Cisco, Utah, part 1, data summary: U.S. Geological Survey Open-File Report, 15 p.

96. Brennan, R., and Grozier, R.U., 1976, Salt-load computations--Colorado River; Cameo, Colorado to Cisco, Utah, part 2, basic data: U.S. Geological Survey Open-File Report, 222 p.

97. Bresler \& Associates, Inc., 1975, Potential application of ion exchange desalting for salinity control in the Colorado River Basin: Salt Lake City, Utah, Bureau of Reclamation, $127 \mathrm{p}$. 
98. Bretz, T.E., 1974, Rules and regulations relating to geothermal leases on Colorado State owned lands, in Proceedings of a symposium on geothermal energy and Colorado: Denver, Colo., Colorado Geological Survey Bulletin 35, p. 91-96.

99. Brito, R.A.L., and Bessler, M.B., 1984, Discussion and reply on Saline water use prospects-Colorado River, by M.B. Bessler, 1983, (in American Society of Civil Engineers, Journal of Irrigation and Drainage Engineering, v. 109, no. 2, p. 221-231): American Society of Civil Engineers, Journal of Irrigation and Drainage Engineering, v. 110, no. 2, p. 260-262.

100. Brittan, M.R., Crow, L.W., Garnsey, M.E., Julian, P.R., Schleusener, R.A., and Yeodjevish, V.M., 1961, Past and probable future variations in streamflow of the Upper Colorado River: Boulder, Colo., University of Colorado. [Part I, summary and conclusions, 24 p.; part II, a study of the statistical predictability of annual runoff in the Upper Colorado River Basin, 98 p.; part III, some general aspects of fluctuations of annual runoff in the Upper Colorado River Basin, 48 p.; part $\mathrm{IV}$, probability analyses applied to the development of synthetic hydrology for the Colorado River, 99 p.; part V, analysis of precipitation data in the Upper Colorado River Basin, 34 p.]

101. Britton, L.J., 1979, Reconnaissance evaluation of surface-water quality in Eagle, Grand, Jackson, Pitkin, Routt, and Summit Counties, Colorado: U.S. Geological Survey Open-File Report 79-420, 285 p.

102. Britton, L.J., and Wentz, D.A., 1980, Water-quality characteristics of selected lakes and reservoirs in Colorado: U.S. Geological Survey Water-Resources Investigations Open-File Report 80-436, $139 \mathrm{p}$.

103. Brogden, R.E., and Giles, T.F., 1976, Availability and chemical quality of ground water in the Crystal River and Cattle Creek drainage basins near Glenwood Springs, west-central Colorado: U.S. Geological Survey Water-Resources Investigations 76-70, 2 sheets, 1:125,000, text included.

104. Brookman, J.A., 1968, Colorado ground-water levels, spring 1968: Fort Collins, Colo., Colorado State University Experiment Station Report CER67-69JB2, 2 sheets, scale 1 inch equals about 5 miles.

105. Brookman, J.A., 1969, Colorado ground-water levels, spring 1969: Fort Collins, Colo., Colorado State University Experiment Station Report CER68-69JB39.

106. Brooks, Tom, 1983, Hydrology and subsidence potential of proposed coal-lease tracts in Delta County, Colorado: U.S. Geological Survey Water-Resources Investigations Report 83-4069, $27 \mathrm{p}$.

107. Brooks, Tom, 1986, Geohydrology and potential hydrologic effects of underground coal mining in the Rapid Creek Basin, Mesa County, Colorado: U.S. Geological Survey Water-Resources Investigations Report 86-4172, 28 p.

108. Brooks, Tom, and Ackerman, D.J., 1985, Reconnaissance of ground-water resources in the lower Gunnison River Basin, southwestern Colorado: U.S. Geological Survey Water-Resources Investigations Report 84-4185, $30 \mathrm{p}$. 
109. Broom, M.E., 1962, Sources of potable water supplies for the U.S. National Park Service recreational area, Crawford Dam and Reservoir site, Delta, Colorado: U.S. Geological Survey Open-File Report, 9 p.

110. Brown, H.E., and Dunford, E.G., 1956, Streamflow in relation to extent of snow cover in central Colorado: U.S. Forest Service Rocky Mountain Forest and Range Experiment Station Paper 24, 9 p.

111. Brown, H.E., and Thompson, J.R., 1965, Summer water use by aspen, spruce, and grassland in western Colorado: Journal of Forestry, v. 63, p. 756-760.

112. Brown, T.C., Harding, B.L., and Payton, E.A., 1990, Marginal economic value of streamflow--A case study for the Colorado River Basin: Water Resources Research, v. 26, no. 12, p. 2845-2859.

The marginal economic value of stream flow leaving forested areas in the Colorado River Basin, USA, was estimated by determining the impact on water use of a small change in stream flow and then applying economic value estimates to the water use changes. The specific objective was to estimate the economic value of increases in runoff that could be created by timber harvest in these areas. The effect on water use of a change in stream flow was estimated with a network flow model that simulated salinity levels and the routing of flow to consumptive uses, including agriculture, and hydroelectric dams throughout the Basin. The results show that, under current water management institutions, the marginal value of stream flow in the Colorado River Basin is largely determined by non-consumptive water uses, principally energy production, rather than by consumptive agricultural or municipal uses. The analysis demonstrates the importance of a systems framework in estimating the marginal value of stream flow.

113. Bruce, C.A., 1933, History of Federal reclamation and its accomplishments on the Uncompahgre Project, Colorado: Gunnison, Colo., Western State College, Master's thesis.

114. Bryant, Bruce, 1972, Map showing ground-water potential in the Aspen quadrangle, Pitkin County, Colorado: U.S. Geological Survey Miscellaneous Investigations Series Map I-785-B, scale $1: 24,000$.

115. Bryant, Bruce, 1972, Map showing relative permeability of rocks and surficial deposits of the Aspen quadrangle, Pitkin County, Colorado: U.S. Geological Survey Miscellaneous Investigations Series Map I-785-F, scale 1:24,000.

116. Buchberger, S.G., 1981, Flood frequency analysis for regulated rivers: Transportation Research Record 832, p. 12-21.

117. Bullock, J.H., Jr., Barton, H.N., Briggs, P.H., and Roemer, T.A., 1989, Analytical results and sample locality map of stream-sediment, heavy-mineral-concentrate, and rock samples from the Gunnison Gorge Wilderness Study Area (CO-030-388), Delta and Montrose Counties, Colorado: U.S. Geological Survey Open-File Report 89-439, 11 p.

118. Bureau of Land Management, 1961, Selected oil shale bibliography, 1895-1961, inclusive: Denver, Colo., Bureau of Land Management, $64 \mathrm{p}$. 
119. Bureau of Land Management, 1975, Draft environmental impact statement proposed development of oil shale resources by the Colony Development Operation in Colorado: Bureau of Land Management.

120. Bureau of Land Management, 1976, Interim report, the feasibility of salinity control from national resource lands in the Upper Colorado River Basin: Denver, Colo., Bureau of Land Management, $82 \mathrm{p}$.

121. Bureau of Land Management, 1976, Status of endangered and threatened fish species in Colorado: Bureau of Land Management Technical Note 280, 23 p.

122. Bureau of Land Management, 1977, Final environmental impact statement, proposed development of oil shale resources by the Colony Development Operation in Colorado, volume II: Washington, D.C., Bureau of Land Management.

123. Bureau of Land Management, 1987, Salinity control on BLM-administered public lands in the Colorado River Basin: Washington, D.C., Bureau of Land Management, 43 p.

124. Bureau of Land Management, 1992, Project plan--Gunnison Gorge instream flow assessment, Uncompahgre Basin Resource Area, Colorado: Montrose, Colo., Bureau of Land Management, $17 \mathrm{p}$.

125. Bureau of National Affairs, Inc., 1991, Colorado water quality standards: Washington, D.C., Bureau of National Affairs, Inc.

126. Bureau of Reclamation, 1940, Report on Blue River-South Platte Project, Colorado: U.S. Department of the Interior Project Investigation Report 42.

127. Bureau of Reclamation, 1946, Blue-South Platte Project, Colorado--A potential transmountain diversion project: U.S. Department of the Interior Project Planning Report 7-8a.1-0.

128. Bureau of Reclamation, 1946, The Colorado River, a natural menace becomes a natural resource: Washington, D.C., Bureau of Reclamation, 293 p. plus 9 maps.

129. Bureau of Reclamation, 1950, Colorado River Storage Project and participating projects--Upper Colorado River Basin: Bureau of Reclamation Project Planning Report 4-81, 81-1, various pagination.

130. Bureau of Reclamation, 1963-1995, Quality of water, Colorado River Basin, progress report: Salt Lake City, Utah, Bureau of Reclamation. [Biennial report of continuing study begun in 1962 on water quality of the basin.]

131. Bureau of Reclamation, 1969, Project Skywater, Proceedings, Skywater conference V, scientific review plans and design of the Colorado River Basin Pilot Project with appendix; design changes and decisions: Denver, Colo., Bureau of Reclamation, 260 p. [Available from National Technical Information Service, Springfield, VA 22161 as NTIS Report PB-185 143.]

Contents: Cascades program and Hungry Horse; Colorado River Basin water situation and Colorado River Basin Project Act; Colorado State University Project Plan and scientific basis; climatology; precipitation; economic aspects; atmospheric water vapor budget; system design and procurement arrangements; social problems, current 
approach and position; evaluation network; and general aspects of recognition-seeding contract and other project support.

132. Bureau of Reclamation, 1971, Colorado River Basin project in cloud seeding, 4 year weather modification experiment in SW Colorado for augmenting water supplies (final environmental impact statement): Washington, D.C., Bureau of Reclamation, 33 p. [Available from National Technical Information Service, Springfield, VA 22161 as NTIS Report PB-210 086-F.]

The project is a test of large-scale application of cloud seeding techniques for increasing snowfall in mountainous areas, using the San Juan Mountain area in southwestern Colorado as a test area. There will be four winter seasons of seeding, beginning with the 1970-71 season. Seeding is being conducted over a 1,300-squaremile target area of the 3,300-square-mile San Juan Mountain project area. The Colorado State University experiments conducted at Climax and at Wolf Creek Pass area of Colorado produced solid evidence that winter cloud seeding with groundbased silver iodide generators can produce an average snowfall increase of 10 to 30 percent. These findings confirm earlier estimates that about 2 million acre-feet more streamflow would be possible from target areas in the Upper Colorado River Basin by cloud seeding. There is concern with regard to the hazards posed by weather to residents and visitors in this mountainous area. In recognition of the social response to dangers posed by avalanches, especially in the Ouray-Silverton-Telluride area, the Bureau decided that there would be no seeding initially in subareas 3 and 4 . Additional snow should not significantly increase snow removal costs. There may be some concern over the potential contamination of the environment by the silver iodide used as the seeding material in this experiment. Silver concentrations measured in precipitation from seeded storms range from 0.000001 to 0.00176 parts per million. Although several studies have concluded that there is no direct hazard to humans from the use of silver iodide as a seeding agent, additional studies are needed to determine if there could be ecological effects of large-scale, long-term use of silver iodide. The ecological monitoring program includes an investigation of residual and long-range accumulation effects of the silver iodide.

133. Bureau of Reclamation, 1971, Crystal Dam, reservoir, and powerplant, Curecanti Unit, Colorado River Storage Project (draft environmental impact statement): Washington, D.C., Bureau of Reclamation, 32 p. [Available from National Technical Information Service, Springfield, VA 22161 as NTIS Report PB-202 071-D.]

Crystal Dam is the final feature of three units planned to generate electrical power from available head in the Gunnison River between Gunnison, Colorado, and the Black Canyon of the Gunnison National Monument. The first two, Blue Mesa and Murrow Point, are completed. Releases from Crystal will provide minimum flows in the Gunnison River which have not been historically available. Major environmental impact will be from removal of concrete aggregate and other channelization work in the river channel. Six and one-half miles of quality stream fishery habitat in the Gunnison River will be inundated. Turbidity in the river will be increased slightly during construction from aggregate processing and channel excavation. Stabilized permanent flows in the Gunnison River will occur below the dam. Inundation will occur in a highly scenic canyon area. 
134. Bureau of Reclamation, 1971, Crystal Dam, reservoir, and powerplant, Curecanti Unit, Colorado River Storage Project (final environmental impact statement): Bureau of Reclamation Report ELR-1356, 53 p. [Available from National Technical Information Service, Springfield, VA 22161 as NTIS Report PB-202 071-F.]

Construction is proposed of Crystal Dam and a hydroelectric powerplant on the Gunnison River, Montrose, Colorado. Adverse environmental effects include inundation of 6.5 miles of trout fishery and high quality river scenery by the reservoir having a maximum depth of 200 feet at the dam and unavoidable turbidity increases during the construction period. (Supersedes report dated August 20, 1971, PB-202 071-D).

135. Bureau of Reclamation, 1972, A joint research proposal on the prediction of mineral quality of return flow water from irrigated land: Denver, Colo., U.S. Federal Water Pollution Control Administration and Bureau of Reclamation, 44 p. plus appendix IV.

136. Bureau of Reclamation, 1973, Crystal Dam, reservoir, and powerplant, Curecanti Unit, Colorado River Storage Project, Colorado (supplement to final environmental impact statement): Bureau of Reclamation Report FES-73-21, 25 p. [Available from National Technical Information Service, Springfield, VA 22161 as NTIS Report EIS-CO-73-0746-F-S.]

Final environmental statement for Crystal Dam, reservoir, and powerplant was filed December 1971. This supplement covers design changes and results of investigations which have occurred since that time. The Crystal damsite is situated on the Gunnison River, 15 miles east of Montrose, Colorado, in Montrose County. Channelizing of the stream below the damsite has been reduced from a length of 8,000 feet to 5,800 feet, lessening the impact on the fishery. Esthetic impact will be minimized by eliminating some overhead power lines, placing part of the crest access road in a tunnel, and moving the powerplant from the abutment toward the center of the dam. Inundation of an additional 11 acres of canyon will be required, including about 1,000 feet of river channel, by raising the reservoir normal water surface 5 feet.

137. Bureau of Reclamation, 1974, Report on water for energy in the Upper Colorado River Basin: Denver, Colo., Bureau of Reclamation, $71 \mathrm{p}$.

138. Bureau of Reclamation, 1974, Water for tomorrow--Colorado State water plan, phase I, appraisal report on water and related land resources and their present utilization: Bureau of Reclamation, $15 \mathrm{p}$.

139. Bureau of Reclamation, 1975, Salinity and sediment study--Upper Colorado River Basin-Utah, Colorado, and Wyoming: Salt Lake City, Utah, Bureau of Reclamation, 80 p.

140. Bureau of Reclamation, 1975, Westside Study report on critical water problems facing the eleven western States: Bureau of Reclamation, $457 \mathrm{p}$.

141. Bureau of Reclamation, 1976, Colorado River Water Quality Improvement Program-Environmental statement: Salt Lake City, Utah, Bureau of Reclamation, 571 p.

142. Bureau of Reclamation, 1976, Floral and terrestrial vertebrate studies of the Grand Valley, Colorado: Bureau of Reclamation, $469 \mathrm{p}$. 
143. Bureau of Reclamation, 1977, Hydrogeologic study--Lower Gunnison Unit: Salt Lake City, Utah, Bureau of Reclamation.

144. Bureau of Reclamation, 1978, Stage One development, Grand Valley Unit, definite plan report--Appendix B, hydrosalinity, land resource, economics: Salt Lake City, Utah, Bureau of Reclamation, various pagination.

145. Bureau of Reclamation, 1981, Final environmental statement, Colorado-Big Thompson/ Windy Gap Project, Colorado: Denver, Colo., Bureau of Reclamation.

146. Bureau of Reclamation, 1981, Saline water use and disposal opportunities--Colorado River Water Quality Improvement Program (special report): Denver, Colo., Bureau of Reclamation, 167 p. [Available from National Technical Information Service, Springfield, VA 22161 as NTIS Report PB-82 123 688.]

This Special Report presents innovative alternative plans for collecting, treating, and transporting saline water for energy development use or disposal in the Colorado River Basin. The concepts developed are considered alternatives to conventional structural salinity control methods which involve lined evaporation ponds and desalination plants. The report addresses the potential cost savings for the most promising alternatives of local saline water use by powerplants and by coal slurry pipeline.

147. Bureau of Reclamation, 1982, Colorado-Big Thompson Project, project data sheet: Denver, Colo., Bureau of Reclamation, 42 p.

148. Bureau of Reclamation, 1982, Colorado River Water Quality Improvement Program, Lower Gunnison Basin Unit, feasibility report/draft environmental impact statement, Upper Colorado region: Salt Lake City, Utah, Bureau of Reclamation.

149. Bureau of Reclamation, 1982, Lower Gunnison Basin Unit, feasibility report--Appendix B, hydrosalinity: Salt Lake City, Utah, Bureau of Reclamation, 86 p.

150. Bureau of Reclamation, 1983, Colorado River Water Quality Improvement program, status report, January 1983: Denver, Colo., Bureau of Reclamation, $126 \mathrm{p}$.

151. Bureau of Reclamation, 1983, Grand Valley salt pickup calculations, Colorado River Basin Salinity Control Project: Grand Junction, Colo., Bureau of Reclamation.

152. Bureau of Reclamation, 1983, Salinity update, special edition, January 1983: Denver, Colo., Bureau of Reclamation.

153. Bureau of Reclamation, 1984, Colorado-Big Thompson Project brochure: Loveland, Colo., Bureau of Reclamation, 9 p.

154. Bureau of Reclamation, 1984, Colorado River system consumptive uses and losses report, 1976-1980: Salt Lake City, Utah, Bureau of Reclamation. [Also published in 1976 for years 1971-75, 65 p.] 
155. Bureau of Reclamation, 1984, Lower Gunnison Basin Unit, feasibility report/final environmental statement, Colorado River Water Quality Improvement Program: Salt Lake City, Utah, Bureau of Reclamation, 204 p.

156. Bureau of Reclamation, 1985, Colorado River Basin Salinity Control Project, Grand Valley Unit, Stage Two development, draft environmental impact statement: Salt Lake City, Utah, Bureau of Reclamation, $146 \mathrm{p}$.

157. Bureau of Reclamation, 1986, Cobble aquifer investigation: Grand Junction, Colo., Bureau of Reclamation, various pagination.

158. Bureau of Reclamation, 1986, Colorado River Basin Salinity Control Project, Grand Valley Unit, Stage Two development, final environmental impact statement: Salt Lake City, Utah, Bureau of Reclamation, $217 \mathrm{p}$.

159. Bureau of Reclamation, 1986, Colorado River Basin Salinity Control Project, Grand Valley Unit, Stage Two development, water resources technical supporting data for the verification memorandum, April 1986: Grand Junction, Colo., Bureau of Reclamation, various pagination.

160. Bureau of Reclamation, 1987, Lower Gunnison Basin Unit--Winter water: Salt Lake City, Utah, Colorado River Water Quality Improvement Program preconstruction project report, $57 \mathrm{p}$.

161. Bureau of Reclamation, 1988, Green Mountain Reservoir, Colorado, water marketing program, final supplement to the final environmental statement, Colorado-Big Thompson, Windy Gap projects, Colorado: Billings, Mont., Bureau of Reclamation, various pagination.

162. Bureau of Reclamation, 1990, Annual operating plans, Colorado-Big Thompson Project, Fryingpan-Arkansas Project, North Platte Project, Western Division system-power operations: Billings, Mont., Bureau of Reclamation.

163. Bureau of Reclamation, 1991, Colorado River Storage Project (under construction), Arizona, New Mexico, Colorado, Utah, and Wyoming: Salt Lake City, Utah, Bureau of Reclamation, 20 p. [Available from National Technical Information Service, Springfield, VA 22161 as NTIS Report PB-91 193 896/XAB.]

The Colorado River Storage Project (CRSP) provides for the comprehensive development of the Upper Colorado River Basin. The project furnishes the long-term regulatory storage needed to permit states in the upper basin to meet their flow obligation at Lee's Ferry, Arizona, as defined in the Colorado River Compact, and still utilize their apportioned water. Water stored by the project provides a portion for direct use in the upper basin. Sediment and flooding are better controlled, and recreation development and fish and wildlife conservation have benefited. Because of project development, a significant amount of electrical energy is produced to meet the needs of the upper basin and adjacent areas.

164. Bureau of Reclamation, and Soil Conservation Service, 1977, Colorado River Water Quality Improvement Program (final environmental statement): Bureau of Reclamation Report FES 77-15, 2 volumes. 
165. Burgi, P.H., 1979, Winter ice jams on the Gunnison River: Bureau of Reclamation Technical Report REC-ERC-79-4, 35 p. [Available from National Technical Information Service, Springfield, VA 22161 as NTIS Report PB-80 131 543.]

The formation, transport, and accumulation of ice on a $14 \mathrm{~km}$ stretch of the Gunnison River in Colorado was studied during a six year period. The Gunnison River, a principal tributary of the Colorado River, has an average elevation of $2,300 \mathrm{~m}$ above sea level for the area studied. Located along the study area are two reservoirs, the Taylor Park Reservoir which is upriver from the Blue Mesa Reservoir at the lower end of the area. Winter conditions are severe with 3 days in January of 1971 having a maximum temperature of $-18^{\circ} \mathrm{C}$ or below with the lowest temperature being $-38^{\circ} \mathrm{C}$. Various river channelization, river snagging, and clearing operations have been performed in an attempt to reduce the ice jamming problem. Since 1967, with the filling of the Blue Mesa Reservoir, descriptive records have been kept on the winter ice jams. Summaries of these annual descriptions are included. Study results show that the elevation of the Blue Mesa Reservoir at the end of November is a major factor in determining the location of the ice jam head at the start of the season. The higher the reservoir, the further upstream the ice jam starts. Clearing and snagging operations have had little effect on reducing the jamming; however, the construction of larger ice collection areas has helped. A good correlation was observed between upstream ice jam movement and average temperature below $-10^{\circ} \mathrm{C}$. Large releases from the Taylor Park Reservoir during the winter contribute to the ice formation problem. Data summaries, maps, and photographs are included.

166. Burkhard, W.T., 1967, Stream fishery studies--Effects of channelization on the trout fishery of Tomichi Creek: Denver, Colo., Colorado Department of Game, Fish, and Parks, Federal Aid Project F-026-R-04, Job 6, 9 p.

167. Burkhard, W.T., 1977, Taylor River flow investigations: Denver, Colo., Colorado Division of Wildlife, Federal Aid Project F-51-R-4, Job Interim Report, Job 1, 49 p.

168. Burkhard, W.T., 1978, Vertebrate associations in lowland versus high elevation river and stream habitat in Colorado, in Graul, W.D., and Bissell, S.J., tech. coords., Lowland river and stream habitat in Colorado--A symposium, Greeley, Colo., October 4-5, 1978: Colorado Chapter of the Wildlife Society and Colorado Audubon Council, p. 52-55.

169. Burkhard, W.T., and Lytle, T.A., 1978, Final report for fish and wildlife resource analysis of the West Divide Project: Grand Junction, Colo., Colorado Division of Wildlife, 310 p.

170. Burkhard, W.T., Smith, N.F., Lytle, T.A., and Burdick, H.E., 1979, Final report for fish and wildlife resource analysis of the Grand Mesa Project: Grand Junction, Colo., Colorado Division of Wildlife, $515 \mathrm{p}$.

171. Busch, D.E., and Smith, S.D., 1993, Effects of fire on water and salinity relations of riparian woody taxa: Oecologia [Heidelberg], v. 94, p. 186-194.

Water and salinity relations were evaluated in recovering burned individuals of the dominant woody taxa from low-elevation riparian plant communities of the southwestern U.S. Soil elemental analyses indicated that concentrations of most nutrients increased following fire, contributing to a potential nutrient abundance 
but also elevated alluvium salinity. Boron, to which naturalized Tamarix ramosissima is tolerant, was also elevated in soils following fire. Lower moisture in the upper $30 \mathrm{~cm}$ of burned site soil profiles was attributed to shifts in evapotranspiration following fire. Higher leaf stomatal conductance occurred in all taxa on burned sites. This is apparently due to higher photosynthetic photon flux density at the midcanopy level and may be partially mitigated by reduced unit growth in resprouting burned individuals. Predawn water potentials varied little among sites, as was expected for plants exhibiting largely phreatophytic water uptake. Midday water potentials in recovering Salix gooddingii growing in the Colorado River floodplain reached levels which are considered stressful. Decreased hydraulic efficiency was also indicated for this species by examining transpiration-water potential regressions. Recovering, burned Tamarix and Tessaria sericea had enriched leaf tissue .delta.13C relative to unburned controls. Higher water use efficiency following fire in these taxa may be attributed to halophytic adaptations and to elevated foliar nitrogen in Tessaria.

Consequently, mechanisms are proposed which would facilitate increased community dominance of Tamarix and Tessaria in association with fire. The theory that whole ecosystem processes are altered by invading species may thus be extended to include those processes related to disturbance.

172. Busterud, J.A., 1974, The future of regional planning in the United States, in Crawford, A.B., and Peterson, D.F., eds., Environmental management in the Colorado River Basin: Logan, Utah, Utah State University Press, p. 67-74.

173. Butcher, W.S., 1978, Salinity management and the development of the Colorado River Basin; a multidisciplinary problem with international implication (1976): Trenton, N.J., Proc. Univ. Semin. Pollut. Water. Resour., v. 9, p. B1-B18.

174. Butcher, W.S., 1979, Salinity management and water resources development: GeoJournal, v. 3, no. 5 , p. $457-460$.

The interrelationship of salinity management and water management is a factor which is sometimes easily overlooked in the water resources planning, even though it can place a limit on the degree of water resource development within a basin. Costs and control measures of salinity management are considered on a case study of the Colorado River Basin where salinity damages are found to be higher than previously estimated. After review of the costs of salinity management, the possible control measures, and research on adaptions in agricultural use of more saline water, it can be concluded that, at the very least, the management of water quantity and water quality, especially in arid regions, are closely intertwined.

175. Butler, D.L., 1985, Discharge and water quality of springs in Roan and Parachute Creek Basins, northwestern Colorado, 1981-83: U.S. Geological Survey Water-Resources Investigations Report 85-4078, 145 p.

176. Butler, D.L., 1986, Sediment discharge in the Colorado River near De Beque, Colorado: U.S. Geological Survey Water-Resources Investigations Report 85-4266, $30 \mathrm{p}$.

177. Butler, D.L., 1987, Sediment discharge in Rock Creek and the effect of sedimentation rate on the proposed Rock Creek Reservoir, northwestern Colorado: U.S. Geological Survey WaterResources Investigations Report 87-4026, 23 p. 
178. Butler, D.L., 1990, Estimated water-quality conditions and potential downstream channel effects of the proposed Rock Creek and Wolford Mountain reservoirs, north-central Colorado: U.S. Geological Survey Water-Resources Investigations Report 89-4177, 101 p.

179. Butler, D.L., Krueger, R.P., Osmundson, B.C., Thompson, A.L., and McCall, S.K., 1991, Reconnaissance investigation of water quality, bottom sediment, and biota associated with irrigation drainage in the Gunnison and Uncompahgre River Basins and at Sweitzer Lake, west-central Colorado, 1988-89: U.S. Geological Survey Water-Resources Investigations Report 91-4103, 99 p.

180. Butler, D.L., Wright, W.G., Hahn, D.A., Krueger, R.P., and Osmundson, B.C., 1994, Physical, chemical, and biological data for detailed study of irrigation drainage in the Uncompahgre Project area and in the Grand Valley, west-central Colorado, 1991-92: U.S. Geological Survey Open-File Report 94-110, 146 p.

181. Cadigan, R.A., Felmlee, J.K., and Rosholt, J.N., 1976, Radioactive mineral springs in Delta County, Colorado: U.S. Geological Survey Open-File Report 76-223, 39 p.

182. Camp, Dresser \& McKee, 1980, Mt. Emmons water quality baseline study, 1978-1979: Denver, Colo., Camp, Dresser \& McKee.

183. Camp, Dresser \& McKee, 1982, Flood insurance study, city of Gunnison, Colorado, Gunnison County: Denver, Colo., Federal Emergency Management Agency.

184. Camp, Dresser \& McKee, 1982, Wastewater facilities plan for the East River Valley, Gunnison County, Colorado: Denver, Colo., Camp, Dresser \& McKee.

185. Campbell, W.J., Josberger, E.G., Gloersen, Per, and Chang, A.T.C., 1987, Microwave snow-water equivalent mapping of the Upper Colorado River Basin, USA, in Proceedings of the second symposium on remote sensing in glaciology held at the University of Cambridge, United Kingdom, 8-9 and 11-12 September 1986: Cambridge, United Kingdom, International Glaciological Society, p. 244-245.

186. Carlson, C.A., and Muth, R.T., 1989, The Colorado River--Lifeline of the American Southwest, in Dodge, D.P., ed., Proceedings of the international large river symposium: Can. Spec. Publ. Fish. Aquat. Sci. 106, p. 220-239.

187. Carpenter, R.H., 1981, Interpretation of water sample analyses, Waunita Hot Springs area, Gunnison County, Colorado, in Zacharakis, T.G., ed., Geothermal resources assessment of Waunita Hot Springs, Colorado: Denver, Colo., Colorado Geological Survey Special Publication 16, p. 26-30.

188. Carrier, J., 1991, The Colorado; a river drained dry: National Geographic, v. 179, no. 6, p. 4-34.

189. Carroon, L.E., 1970, Correlative estimates of streamflow in the Upper Colorado River Basin: U.S. Geological Survey Water-Supply Paper 1875, 145 p. 
190. Casey, E.G., 1980, Appendix to volume 1--Energy development scenarios for the Four Corners States and the Upper Colorado River Basin, in Spofford, W.O., Jr., Parker, A.L., and Kneese, A.V., eds., Energy development in the Southwest, problems of water, fish and wildlife in the Upper Colorado River Basin, volume 1: Washington, D.C., Resources for the Future, Research Paper R-18, p. 448-523.

191. Casey, H.E., 1972, Salinity problems in arid lands irrigation--A literature review and selected bibliography: Tucson, Ariz., University of Arizona Institute Arid Lands Res. Inf. Paper 1, 311 p. [Also available from National Technical Information Service, Springfield, VA 22161 as NTIS Report PB-214 172/9.1

Bibliography of 986 references with a review of such broad topics as (1) water quality of the total drainage basin, (2) control of salinity and soil reclamation, (3) effects of drought on salts in plants, soil, and water, (4) basic water balance problems related to irrigation, and (5) historical perspective of problems caused by salinity. The Colorado River Basin was used as an example of a microcosm in which socioeconomic factors are considered.

192. Center for Public-Private Sector Cooperation, 1993, Recommendations on the legal, policy, and institutional issues related to instream flow protection in Colorado: Boulder, Colo., University of Colorado, Colorado River Recovery Implementation Program Report.

193. Chadwick, D.G., 1968, Electronic analog simulation of the salinity flow system within the Upper Colorado River Basin, first annual progress report, FWPCA Demonstration Project WPD 178-01-67: Logan, Utah, Utah Water Resources Laboratory, 73 p.

194. Chamberlain, T.K., 1946, Fishes, particularly the suckers, Catostomidae, of the Colorado River drainage and of the Arkansas River drainage, in relation to the Gunnison-Arkansas transmountain diversion: College Station, Tex., U.S. Fish and Wildlife Service.

195. Champion, D.F., Kruse, E.G., Olsen, S.R., and Kincaid, D.C., 1991, Salt movement under levelbasin irrigation: American Society of Civil Engineers, Journal of Irrigation and Drainage Engineering, v. 117, no. 5, p. 642-655.

Level-basin irrigation has been studied at two sites in western Colorado for seven years. This paper describes changes in the salinity profile in the root zone under levelbasin irrigation. On soils with initially low salt content, salt concentrations in the soil profiles increased under level-basin irrigation, because the irrigation efficiencies are greater than for prior practices. Conversely, good water management and uniform applications on level basins lowered the salt content in the top $60 \mathrm{~cm}$ of soils with high initial salt content. After a few years of level-basin irrigation with Colorado River water, in either case, the salt content equilibrated at levels that do not restrict growth of common field crops.

196. Chaney, T.H., Kuhn, Gerhard, Brooks, Tom, and others, 1987, Hydrology of Area 58, Northern Great Plains and Rocky Mountain coal provinces, Colorado and Utah: U.S. Geological Survey Water-Resources Investigations Open-File Report 85-479, 103 p. 
197. Chase, K.J., 1992, Gunnison River thresholds for gravel and cobble motion, Black Canyon of the Gunnison National Monument: Fort Collins, Colo., Colorado State University, Master's thesis, $104 \mathrm{p}$.

198. Chauvenet, Regis, 1890 , Analyses of natural, thermal, and mineral waters of Colorado: Colorado School of Mines Biennial Report, v. 1890, p. 21-29.

199. Chew, R.T., III, 1974, Geology, hydrology, and extraction operations at the Occidental Petroleum Corporation oil shale plant near De Beque, Colorado, in Murray, D.K., ed., Energy resources of the Piceance Creek Basin, Colorado: Denver, Colo., Rocky Mountain Association of Geologists, 25th field conference, Guidebook, p. 135-140.

200. Chrisman, J., Jr., Synder, J.H., and Moore, C.V., 1976, Water problems in the Colorado River Basin--Legal and institutional framework: Bureau of Reclamation Report OWRT-B-094CAL(3), 77 p. [Available from National Technical Information Service, Springfield, VA 22161 as NTIS Report PB-263 033/3.]

A comprehensive review is presented of state, interstate, and international arrangements, agreements, contracts and legal decisions that have governed or now dictate management of the waters in the Colorado River. Emphasis is placed on legal and institutional arrangements as they relate to water quality management problems. Implications of recent decisions governing construction of a desalting plant are included.

201. Christensen, R.C., Johnson, E.B., and Plantz, G.G., 1985, Streamflow characteristics of the Colorado River Basin in Utah through September 1981: U.S. Geological Survey Open-File Report 85-421, 674 p.

202. Claassen, H.C., 1971, Radiochemical analyses of water from selected streams and precipitation collected immediately before and after the second production-test flaring, Project Rulison: U.S. Geological Survey, 10 p. [Available from National Technical Information Service, Springfield, VA 22161 as NTIS Report USGS-474-122 (Rulison 10).]

The U.S. Geological Survey established a water-sampling network in central and western Colorado to sample the hydrologic environment prior to, during, and following the various phases of Project Rulison. Project Rulison is an experiment designed to stimulate production of natural gas by explosion of a nuclear device in the gas-reservoir rock. Data obtained by analysis of samples collected from the network stations are presented. All of the precipitation samples are routinely analyzed for tritium. Stream samples collected at Plateau Creek near Cameo and Colorado River near De Beque are routinely analyzed for tritium, gross alpha, and gross beta contents. Data are tabulated from samples collected in conjunction with the second production flaring (December 1 to December 20,1970). The period of observation was one of undetectable amounts of tritium in precipitation and lower than the first production flaring values for both tritium and gross radioactivity in streams.

203. Clark, M., Ingvalson, R.D., Oster, J.D., Rhoades, J.D., and Tucker, J.M., 1974, Minimizing the salt burdens of irrigation drainage waters: Journal of Environmental Quality, v. 4, no. 4, p. 311-316. 
204. Clary, W.P., McArthur, E.D., Bedunah, D., and Wambolt, C.L., 1992, Proceedings-Symposium on ecology and management of riparian shrub communities, held in Sun Valley, Idaho, on May 29-31, 1991: U.S. Forest Service General Technical Report INT-289, 241 p. [Available from National Technical Information Service, Springfield, VA 22161 as NTIS Report PB-92 227 784/XAB.]

The report includes 41 papers and accounts of field trips from a symposium focused on riparian shrub communities and their habitats. The papers discuss values, classification methods, conditions, and rehabilitation techniques for riparian areas, with one section devoted to similar topics for upland shrubs.

205. Clinton, M.J., 1981, The Colorado, in Jenkins, S.H., ed., New developments in river basin management, proceedings of specialised conference, Cincinnati, Ohio, June 29-July 3, 1980: Water Science and Technology, v. 13, no. 3, p. 245-265.

206. Clyde, C.G., Falkenborg, D.H., and Riley, J.P., eds., 1976, Colorado River Basin modeling studies: Logan, Utah, Utah Water Resources Laboratory Proc. Seminar, 615 p.

207. Coats, R., 1984, The Colorado River; river of controversy: Environment, v. 26, no. 2, p. 6-13, 36-40.

The institutions and mechanisms for allocating the waters of the Colorado River between the upper and lower parts of the basin were developed during an era of rapid growth. With the available water supply now fully appropriated, a report from a recent symposium suggests new initiatives that are better suited to an era of water management.

208. Cochran, B.J., Hodges, H.E., Livingston, R.K., and Jarrett, R.D., 1979, Rainfall-runoff data from small watersheds in Colorado, October 1974 through September 1977: U.S. Geological Survey Open-File Report 79-1261,673 p.

209. Cochran, B.J., Minges, D.R., Jarrett, R.D., and Veenhuis, J.E., 1983, Rainfall-runoff data from small watersheds in Colorado, October 1977 through September 1980: U.S. Geological Survey Open-File Report 82-873, 755 p.

210. Coe, B.A., 1978, Geothermal energy development in Colorado--Processes, promises and problems: Denver, Colo., Colorado Geological Survey Information Series 9, 52 p.

211. Coe, B.A., 1979, An opportunity-direct use of hydrothermal energy in Colorado, in Expanding the geothermal frontier, Transactions Geothermal Resources Council annual meeting, Reno, Nev.: Davis, Calif., Geothermal Resources Council, p. 117-119.

212. Coe, B.A., 1979, Colorado geothermal commercialization program, semi-annual progress report, January-June, 1979: U.S. Department of Energy Report DOE/ID12018-1.

213. Coe, B.A., 1980, Colorado geothermal commercialization project, semi-annual progress report, State geothermal commercialization programs in the Rocky Mountain basin and range region, chapter 3: U.S. Department of Energy Report DOE/ID/12018-1. 
214. Coe, B.A., 1981, Geothermal energy opportunities in four Colorado towns: Denver, Colo., Colorado Geological Survey Open-File Report 81-2, 60 p.

215. Coe, B.A., 1982, Industrial market opportunities for geothermal energy in Colorado: Denver, Colo., Colorado Geological Survey Special Publication 20,66 p.

216. Coffin, D.L., and Bredehoeft, J.D., 1969, Digital computer modeling for estimating mine drainage problems: U.S. Geological Survey Open-File Report, 24 p.

217. Coffin, D.L., Welder, F.A., and Glanzman, R.K., 1971, Geohydrology of the Piceance Creek structural basin between the White and Colorado Rivers, northwestern Colorado: Denver Colo., U.S. Geological Survey Hydrologic Investigations Atlas HA-370, 2 sheets, scale 1:125,000.

218. Coffin, D.L., Welder, F.A., Glanzman, R.K., and Dutton, X.W., 1968, Geohydrologic data from the Piceance Creek Basin between the White and Colorado Rivers, northwestern Colorado: Denver, Colo., Colorado Ground Water Circular 12, 38 p.

219. Colburn, T., 1981, Aquatic insects as measures of trace element presence--Cadmium and molybdenum: Gunnison, Colo., Western State College, Master's thesis.

220. Colburn, T., 1982, Aquatic insects as measures of trace element presence in water--Cadmium and molybdenum, in Pearson, J.G., Foster, R.G., and Bishop, W.E., eds., Aquatic toxicology and hazard assessment, fifth conference: Philadelphia, Pa., American Society for Testing and Materials, p. 316-325.

221. Colburn, T., 1982, Measurements of low levels of molybdenum in the environment using aquatic insects: Bulletin of Environmental Contamination and Toxicology, v. 29, p. 422-428.

222. Collins, D.L., 1985, Spring 1984 runoff in the Colorado River Basin, in U.S. Geological Survey, National water summary 1984--Hydrologic events, selected water-quality trends, and groundwater resources: U.S. Geological Survey Water-Supply Paper 2275, p. 42-43.

223. Collins, D.L., Doesken, N.J., and Stanton, W.P., 1991, Colorado floods and droughts, in Paulson, R.W., Chase, E.B., Roberts, R.S., and Moody, D.W., comps., U.S. Geological Survey, National water summary 1988-89--Hydrologic events and floods and droughts: U.S. Geological Survey Water-Supply Paper 2375, p. 207-214.

224. Collins, W.D., and Howard, C.S., 1928, Quality of water of Colorado River in 1925-26, chap. B of Contributions to the hydrology of the United States, 1927: U.S. Geological Survey WaterSupply Paper 596, p. 33-43.

225. Colony Development Corporation, 1974, An environmental impact analysis for a shale oil complex at Parachute Creek, Colorado, part 1--Plant complex and service corridor: Denver, Colo., Atlantic Richfield Company, 349 p.

226. Colony Development Corporation, 1974, Oil shale--A symposium for environmental leaders: Denver, Colo., Atlantic Richfield Company.

227. Colony Development Corporation, 1974, Water studies, Colony Development Operation environmental impact analysis, appendix 12: Denver, Colo., Atlantic Richfield Company, various pagination. 
228. Colorado Climate Center, 1984, Colorado average annual precipitation 1951-1980: Fort Collins, Colo., Colorado Climate Center, scale 1:500,000.

229. Colorado Department of Game, Fish, and Parks, 1969, Water pollution studies--Study of the effects of mineral mining and milling operations on high mountain streams: Denver, Colo., Colorado Department of Game, Fish, and Parks, Federal Aid Project F-33-R, Progress Report.

230. Colorado Department of Health, 1970, Guidelines for control of water pollution from mine drainage: Denver, Colo., Colorado Department of Health.

231. Colorado Department of Health, 1973, Preliminary report on the investigation of the water quality of the Roaring Fork River and its tributaries: Denver, Colo., Colorado Department of Health, $27 \mathrm{p}$.

232. Colorado Department of I Jealth, 1976, Report on the investigation of the water quality of the Colorado River--Dotsero, Colorado to Utah border: Denver, Colo., Colorado Department of Health, $49 \mathrm{p}$.

233. Colorado Department of Health, 1979, The Crystal River drainage study, August, 1978 to May, 1979: Denver, Colo., Colorado Department of Health, 52 p.

234. Colorado Department of Health, 1988, Classifications and numeric standards for Gunnison and lower Dolores River Basins: Denver, Colo., Colorado Department of Health, $23 \mathrm{p}$.

235. Colorado Department of Local Affairs, 1980, Water quality management plan for District 10: Denver, Colo., Colorado Department of Health.

236. Colorado Division of Wildlife, 1954, A field survey of western Colorado streams and fishes: Fort Collins, Colo., Colorado Division of Wildlife, 29 p.

237. Colorado Division of Wildlife, 1975, Fish and wildlife analysis for the Dallas Creek Water Project: Denver, Colo., Colorado Division of Wildlife, 225 p.

238. Colorado Geological Survey, 1978, Geothermal energy--Colorado's untapped resource: Denver, Colo., Colorado Geological Survey pamphlet.

239. Colorado Governor's Oil Shale Advisory Committee, 1971, Report on economics of environmental protection for a federal oil shale leasing program: Denver, Colo., Colorado Geological Survey, 204 p.

240. Colorado Land Use Commission, 1974, Colorado land use map folio: Colorado Land Use Commission, 12 maps.

241. Colorado Land Use Commission, 1974, Sediment yield map of Colorado: U.S. Department of Agriculture, Soil Conservation Service.

242. Colorado League of Women Voters, 1958, Colorado's water resources: Denver, Colo., Colorado League of Women Voters, $50 \mathrm{p}$.

243. Colorado Legislative Council, 1965, Water pollution in Colorado, report to the Colorado General Assembly: Colorado Legislative Council Resources Publication 105, 57 p. 
244. Colorado River Basin Salinity Control Forum, 1975, Water quality standards for salinity including numeric criteria and plan of implementation for salinity control--Colorado River system: Salt Lake City, Utah, Upper Colorado River Commission, 136 p. plus appendices A-G.

Reports the water quality standards of all seven states in a single document. Standards must be established for all interstate waters as specified in the Water Pollution Control Act Amendments of 1972, PL 92-500, Section 303. Also provides information on the past, present, and projected salinity levels of the Colorado River. Salinity control programs that may decrease salinity levels are given.

245. Colorado River Basin Salinity Control Forum, 1984, Water quality standards for salinity, Colorado River system, 1984 review: Bountiful, Utah, Colorado River Basin Salinity Control Forum, $129 \mathrm{p}$.

246. Colorado River Basin Salinity Control Forum, 1987, Water quality standards for salinity, Colorado River system proposed report on the 1987 review: Bountiful, Utah, Colorado River Basin Salinity Control Forum.

247. Colorado River Basin Salinity Control Forum, 1993, Water quality standards for salinity, Colorado River system final report: Bountiful, Utah, Colorado River Basin Salinity Control Forum, various pagination.

248. Colorado State Engineers Office, 1967, Ground water laws 1965, amended 1967: Denver, Colo., Colorado Division of Water Resources, $28 \mathrm{p}$.

249. Colorado State Planning Office, 1959, Underground water supply, in Colorado year book, 1956-1958: Denver, Colo., Colorado State Planning Office, p. 461.

250. Colorado State Planning Office, 1962, Springs of Colorado, in Colorado year book, 1959-1961: Denver, Colo., Colorado State Planning Office, p. 470-471.

251. Colorado State Planning Office, 1970, Eagle County water and sewer facility plan: Denver, Colo., Colorado State Planning Office, 71 p.

252. Colorado State University, 1976, Irrigation field days report, 1976, a report of CSU's salinity research in Grand Valley sponsored by the EPA: Fort Collins, Colo., Colorado State University, $55 \mathrm{p}$.

253. Colorado State University, 1978, Integrating desalination and agricultural salinity control alternatives (environmental protection technology series): U.S. Environmental Protection Agency Report EPA 600/2-78-074.

254. Colorado State University, 1981, Monitoring and evaluation of on-farm irrigation improvements in the Grand Valley Salinity Control Project: Fort Collins, Colo., Colorado State University Report AER 80-81GVS-SSK-EGK4.

255. Colorado State University, 1983, Monitoring and evaluation of on-farm irrigation improvements in the Grand Valley Salinity Control Project: Fort Collins, Colo., Colorado State University Report ACER 82-83MSS-GVS-JCL-SMS-PHR-BH-GB-1. 
256. Colorado Water Conservation Board, 1957, Colorado's water resources; report prepared for Department of Natural Resources, State of Colorado: Denver, Colo., Colorado Water Conservation Board, 13 p.

257. Colorado Water Conservation Board and U.S. Department of Agriculture, 1965, Water and related land resources--Colorado River Basin in Colorado: Denver, Colo., Colorado Water Conservation Board and U.S. Department of Agriculture, Forest Service and Soil Conservation Service, $183 \mathrm{p}$.

258. Colorado Water Conservation Board and U.S. Department of Agriculture, 1965, Water and related land resources--Gunnison River Basin in Colorado: Denver, Colo., Colorado Water Conservation Board and U.S. Department of Agriculture, Forest Service and Soil Conservation Service, $103 \mathrm{p}$.

259. Colorado Water Pollution Control Commission, 1967, Stream classification for surface waters of Colorado: Denver, Colo., Colorado Department of Health, various pagination.

260. Colorado Water Pollution Control Commission, 1970, Guidelines for control of water pollution from mine drainage: Denver, Colo., Colorado Department of Health, $10 \mathrm{p}$.

261. Colorado Water Pollution Control Commission, 1971, Water quality standards and stream classification: Denver, Colo., Colorado Department of Health, 30 p.

262. Colorado Water Quality Control Commission, 1982, Colorado River salinity standards: Denver, Colo., Colorado Department of Health.

263. Colorado Water Quality Control Commission, 1984, Water quality standards for Colorado: Denver, Colo., Colorado Department of Health.

264. Colorado Water Quality Control Commission, 1985, Classifications and numeric standards for the Upper Colorado River Basin: Denver, Colo., Colorado Department of Health.

265. Colorado Water Quality Control Division, 1988, Colorado nonpoint assessment report: Denver, Colo., Colorado Department of Health, 160 p.

266. Colorado Water Quality Control Division, 1989, Colorado nonpoint assessment report--1989 addendum: Denver, Colo., Colorado Department of Health, $189 \mathrm{p}$.

268. Colorado Water Quality Control Division, 1994, Status of water quality in Colorado: Denver, Colo., Colorado Department of Public Health and Environment, 141 p. [Also published in 1992, 1990, 1988, and 1986 as Colorado Water Quality.]

269. Colorado Water Resources Research Institute, 1981, A five year plan for water research in Colorado: Bureau of Reclamation Report W82-05531, 133 p. [Available from National Technical Information Service, Springfield, VA 22161 as NTIS Report PB-82 232 059.]

This report covers a detailed description of Colorado water resources, the institutional interrelationships of Colorado water organizations, and the projected five-year water resources research plan. A listing of 22,14,21,36, and 31 researchable water problems of high priority for Colorado is given for the five generic research categories: atmospheric/hydrologic/hydraulic processes; ecological-environmental 
relationships; water quality processes/prediction/protection; water resources management; and institutional/political/legal/behavioral/economic analysis, respectively.

270. Colorado Water Resources Research Institute, 1983, Water resources research coordination and planning in the Colorado River-Great Basin region: Bureau of Reclamation Report OWRT-B-146-COLO(1), 94 p. [Available from National Technical Information Service, Springfield, VA 22161 as NTIS Report PB-83 194 126.]

This report summarizes regional research planning and implementation activities carried on by the Consortium of Colorado River-Great Basin Water Institutes and Centers (CWIC) beginning in FY1973. At that time a regional research program was initiated in response to Congressional concerns over the need for research concerning water problems common to two or more states. Administrative funds were allocated to one Institute in each region for use in initiating this new program. The Colorado Institute was selected as the administrative manager for the Colorado River-Great Basin Region. Seven states are within that region, including Colorado, Wyoming, New Mexico, Utah, Nevada, Arizona, and California.

271. Colorado West Group, 1975, Environmental assessment for water and sewer systems, Black Canyon of the Gunnison National Monument: Colorado West Group. [Prepared for U.S. Department of the Interior National Park Service, Rocky Mountain Region.]

272. Comstock, T.B., 1889, Hot springs formations in Red Mountain district, Colorado; a reply to the criticism of Mr. Emmons: American Institute of Mining Engineers Transactions 17, p. 261-264.

273. Condes de la Torre, Alberto, 1982, Support by the U. S. Geological Survey for adjudications, compacts, and treaties: U.S. Geological Survey Open-File Report 82-680, 28 p.

274. Cook, C.W., 1974, Surface rehabilitation of land disturbances resulting from oil shale development, executive summary: Fort Collins, Colo., Colorado State University, Environmental Resources Center Information Series 11, $56 \mathrm{p}$.

275. Cook, C.W., ed., 1974, Surface rehabilitation of land disturbances resulting from oil shale development: Fort Collins, Colo., Colorado State University, Environmental Resources Center Technical Report Series 1, $255 \mathrm{p}$.

276. Cooper, D.J., 1993, Wetlands of the Crested Butte region--Mapping, functional evaluation, hydrologic regime: Crested Butte, Colo., Town of Crested Butte.

277. Cooper, D.J., and Lee, L.C., 1987, Rocky Mountain wetlands--Ecosystems in transition: National Wetlands Newsletter, v. 9, no. 3, p. 2-6.

278. Cope, O.B., 1977, Index to fishery publications of the Colorado Division of Wildlife: Colorado Division of Wildlife Report DOW-R-D-8-77, 100 p. 
279. Corbett, D.M., Hotchkiss, R.H., and Riley, J.P., 1981, Sedimentation--Its occurrence and treatment potential in the Upper Colorado River Basin, in Grenney, W.J., ed., Proceedings of the symposium on utilizing scientific information in environmental quality planning, Las Vegas, Nevada, September 26-27, 1979: Minneapolis, Minn., American Water Resources Association Technical Publication Series TPS81-2, p. 186-202.

280. Costa, J.E., and Jarrett, R.D., 1981, Debris flows in small mountain stream channels of Colorado and their hydrologic implications: Association of Engineering Geologists Bulletin, v. 18 , p. 309-322.

281. Covay, K.J., and Tobin, R.L., 1981, Quality of ground water in Routt County, northwestern Colorado: U.S. Geological Survey Water-Resources Investigations Open-File Report 80-956, 38 p. [Available from Colorado District, U.S. Geological Survey, Water Resources Division, Room H-2103, Building 53, Denver Federal Center, Denver, Colo. (mailing address: Box 25046, Mail Stop 415, Denver Federal Center, Denver, CO 80225-0046).]

282. Cowan, M.S., Cheney, R.W., and Addiego, J.C., 1981, Colorado River Simulation System-An executive summary: Denver, Colo., Bureau of Reclamation, 19 p. [Available from National Technical Information Service, Springfield, VA 22161 as NTIS Report PB-82 139 387.]

The CRSS (Colorado River Simulation System) is a deterministic digital computerized simulation model that has been developed by the Bureau of Reclamation in accordance with the 'Law of the River.' With CRSS, proposed changes to the operation or alternative development schemes of the river system can be modeled and their effect on the future quantity and quality of water in the river may be evaluated.

283. Craig, T.W., 1971, Groundwater of the Uncompahgre Valley, Montrose County, Colorado: Rolla, Mo., University of Missouri, Master's thesis, 113 p.

284. Crandall, D.L., 1974, Management objectives in the Colorado River Basin--The problem of establishing priorities and achieving coordination, in Crawford, A.B., and Peterson, D.F., eds., Environmental management in the Colorado River Basin: Logan, Utah, Utah State University Press, p. 17-23.

285. Crawford, A.B., and Peterson, D.F., eds., 1974, Environmental management in the Colorado River Basin: Logan, Utah, Utah State University Press, 313 p.

286. Crewdson, R.A., 1976, A geothermal assessment of Colorado, in Field guidebook for conference on exploration for the geothermal reservoir, May 4-5, 1976: Golden Colo., Colorado School of Mines, p. 35

287. Crifasi, R.R., in press, Alluvial aquifers along the Colorado River, in Colorado ground water atlas: Denver, Colo., Colorado Ground Water Association.

288. Cringan, A.T., and Kilburn, P.D., 1973, Environmental planning for oil shale production in western Colorado: Transactions of the North American Wildlife and Natural Resources Conference, v. 38 , p. $445-458$.

289. Cudlip, L., 1992, High Country Citizens' Alliance water quality report, 1991-1992: Crested Butte, Colo., High Country Citizens' Alliance, 24 p. 
290. Cudlip, L.S., 1993, Summary of water quality studies for the East and Slate River drainages: Gunnison, Colo., Upper Gunnison River Water Conservancy District, 73 p.

291. Cudlip, L.S., French, R.D., and Hickman, D., 1987, Blue Mesa Reservoir, Colorado--A historical review of its limnology, 1965-1985: Bureau of Reclamation Report REC-ERC-87-3, 59 p.

292. Day, M.J., and Perry, H.A., 1985, Hydrogeologic characterization of the Colony Shale Oil Project area, in Gary, J.H., ed., Eighteenth oil shale symposium proceedings: Golden, Colo., Colorado School of Mines Press, p. 58-67.

293. Decker, E.R., 1973, Geothermal studies in southern Rocky Mountain region, 1971-1973 [abs.]: Geological Society of America Abstracts with Programs, v. 5, no. 6, p. 475-476.

294. Decker, E.R., 1979, Thermal gradients and heat flow data in Colorado and Wyoming: Los Alamos, N. Mex., Los Alamos Scientific Laboratory Report LA-7993 ms.

295. Decker, E.R., and Birch, Francis, 1974, Basic heat-flow data from Colorado, Minnesota, New Mexico and Texas, in Sass, J.H., and Munroe, R.J., comps., Basic heat-flow data for the United States: U.S. Geological Survey Open-File Report 74-9, p. 5-6-5-9 [Colorado].

296. Del Rio, S.M., comp., 1960, Mineral resources of Colorado, 1st sequel: Denver, Colo., Colorado Mineral Resources Board, $764 \mathrm{p}$.

297. Delany, R., 1966, Water for oil shale development: Denver Law Journal, v. 43, no. 1, p. $72-82$.

298. Desborough, G.A., 1992, Ion exchange capture of copper, lead, and zinc in acid-rock drainages of Colorado using natural clinoptilolite--Preliminary field studies: U.S. Geological Survey Open-File Report 92-614, 16 p.

299. Desborough, G.A., 1994, Efficacy of heavy-metal capture by clinoptilolite-rich rocks from heavy-metal-polluted water in five drainages in Colorado: U.S. Geological Survey Open-File Report 94-140, 25 p.

300. Deyo, A.E., 1984, Salinity investigations of Mancos Shale landforms and springs in the Upper Colorado River Basin: Davis, Calif., University of California, Ph.D. dissertation, 200 p.

301. Dickinson, W.E., 1944, Summary of records of surface waters at base stations in Colorado River Basin, 1891-1938: U.S. Geological Survey Water-Supply Paper 918, 274 p.

302. District 10 Regional Planning Commission, 1983, Draft 1983 update to water quality management plan for District 10: Denver, Colo., District 10 Regional Planning Commission and Colorado Water Quality Control Division.

303. District 10 Regional Planning Commission, 1986, Water quality management plan, District 10 , State of Colorado: Montrose, Colo., District 10 Regional Planning Commission.

304. District 10 Regional Planning Commission, 1987, Draft 1986/1987 East/Slate River study summary report: Montrose, Colo., District 10 Regional Planning Commission. 
305. Dodson, S.I., 1982, Chemical and biological limnology of six west-central Colorado mountain ponds and their susceptibility to acid rain: American Midland Naturalist, v. 107, no. 1, p. 173-197.

306. Dodson, V.E., 1975, The distribution and habitat separation of three corixids (Hemiptera: Heteroptera) in western Colorado: Freshwater Biology, v. 5, p. 141-150.

307. Doesken, N.J., McKee, T.B., and Richter, D.B., 1984, Analysis of Colorado average annual precipitation for the 1951-1980 period: Fort Collins, Colo., Colorado State University, Colorado Climate Center Climatology Report 84-4, 53 p.

308. Dolson, J., 1982, The Black Canyon of the Gunnison, a story in stone--The natural and human history of Black Canyon of the Gunnsion National Monument: Boulder, Colo., Pruett Publishing, $53 \mathrm{p}$.

309. Dougherty, S.T., 1989, Evaluation of the applicability of the Wetland Evaluation Technique to high elevation wetlands in Colorado, in Fisk, D.W., ed., Proceedings of the symposium on wetlands--Concerns and successes, Tampa, Florida, September 17-22, 1989: Bethesda, Md., American Water Resources Association Technical Publication Series TPS-89-3, p. 415-427.

310. Dougherty, S.T., 1989, Evaluation of the applicability of WET (the Wetland Evaluation Technique) to high elevation wetlands in Colorado: Denver, Colo., ERO Resources Corp., 12 p.

311. Dougherty, S.T., Berry, C.A., and Deimel, M.A., 1987, Hydrology and vegetation in montane and subalpine wetlands of Colorado, in Mutz, K.M., and Lee, L.C., eds., Proceedings of the Society of Wetland Scientists' 8th annual meeting, Seattle, Washington: p. 81-84.

312. Dregne, H.E., 1975, Salinity aspects of the Colorado River agreement: Natural Resources Journal, v. 15, no. 1, p. 43-53.

313. Driver, N.E., 1994, National Water-Quality Assessment Program--Upper Colorado River Basin: U.S. Geological Survey Open-File Report 94-102, 2 p. [Water Fact Sheet]

314. Dufford, R.G., Zimmerman, H.J., Cline, L.D., and Ward, J.V., 1987, Responses of epilithic algae to regulation of a Rocky Mountain stream, in Craig, J.F., and Kemper, J.B., eds., Regulated streams--Advances in ecology: New York, N.Y., Plenum Press, p. 383-390.

315. Duffy, C.J., 1984, Conceptual models of geologic and agricultural salt loads in streams of the Upper Colorado River Basin, in French, R.H., ed., Salinity in watercourses and reservoirs, proceedings of the 1983 international symposium on state-of-the-art control of salinity, Salt Lake City, Utah, July 13-15, 1983: Stoneham, Mass., Butterworth Publishers, p. 223-233.

It is generally held that downstream salinity increases are caused by two predominant factors: (1) salt concentrating processes, such as evaporation and consumptive use by irrigated crops and native vegetation and, (2) salt loading processes which result from dissolution and weathering of residual salts from soil and geologic strata by infiltration of excess irrigation water and natural recharge. 
316. Duffy, C.J., Jurinak, J.J., Korom, S., McCalpin, J., and Corey, P., 1989, Groundwater investigation of sulfate diffusion from a Cretaceous shale hillslope--Upper Colorado River Basin (technical completion report): U.S. Geological Survey G-1308, 157 p. [Available from National Technical Information Service, Springfield, VA 22161 as NTIS Report PB-90 129 156/XAB.]

In the research, the authors have examined the role of advection, diffusion, and dispersion in the generation and transport of groundwater salinity from hillslopes to streams of the Upper Colorado River Basin, hereafter defined as the UCRB. The goal of the study was to coordinate field experiments and theoretical-computer experiments in order to gain insight into the way that subsurface salinity fronts are mobilized and transported from hillslopes of the Colorado Plateau and to better understand the mechanics of the groundwater system within surficial deposits which generate the observed accumulation of salinity in the Colorado River system.

317. Duffy, C.J., Jurinak, J.J., Sangani, S., and Azimi, A., 1985, Identification and modeling the impact of marine shale bedrock on groundwater and stream salinity--Upper Colorado River Basin: Logan, Utah, Utah Water Research Laboratory Hydraulics and Hydrology Series 85-01, 104 p. [Available from National Technical Information Service, Springfield, VA 22161 as NTIS Report PB-86 167 632/XAB.]

Recent stream studies have shown that groundwater is a major contributor to stream salinity in the Upper Colorado River Basin. The primary salt sources are the marine shales that underlie the soils of much of the basin. A field site in the Price River Basin, a tributary to the Green and Colorado Rivers, was selected to study the physical and chemical factors that control the interactions between groundwater and these shales. On the basis of the CH2M Hill study and additional data collected during the study, groundwater flow paths, salt transport and weathering processes were identified. Results show that the groundwater evolves from a calcium-bicarbonate water to a sodium-sulfate water with a depth and distance along the flow paths. Geochemical equilibrium modeling and mass balance computations were performed using the USGS models PHREEQE and BALANCE. A preliminary saturated-unsaturated twodimensional flow model (UNSAT) was implemented along the identified groundwater flow path.

318. Duffy, C.J., and Sangani, S., 1985, The impact of low permeable marine strata on groundwater and stream salinity in the Upper Colorado River Basin [abs.], in Neuman, S.P., and Simpson, E.S., eds., Hydrogeology of rocks of low permeability: International Association of Hydrogeologists, 17th International Congress, Tucson, Ariz, Jan. 7-12, 1985, [Proceedings], p. 796.

319. Duke, H.R., 1967, Colorado ground-water levels--Spring 1967: Fort Collins, Colo., Colorado State University Experiment Station Technical Report CER66-67HRD54, 4 plates.

320. Duke, H.R., Kruse, E.G., Olsen, S.R., Champion, D.F., and Kincaid, D.C., 1976, Irrigation return flow water quality as affected by irrigation water management in the Grand Valley of Colorado: Fort Collins, Colo., U.S. Department of Agriculture, 123 p. [Also published as U.S. Environmental Protection Agency Report EPA IAG-D4-0545.] 
321. Duke, H.R., and Skinner, M.M., 1965, Colorado ground-water levels--Spring 1965: Fort Collins, Colo., Colorado State University Experiment Station Technical Report CER65HRD-MMS29, 4 plates.

322. Duke, H.R., and Sundaram, A.V., 1966, Colorado ground-water levels--Spring 1966: Fort Collins, Colo., Colorado State University Experiment Station Technical Report CER66HRD15, 4 plates.

323. Dumas, A.J., and Morel-Seytoux, H.J., 1971, Detection of a change in runoff by an analysis of daily flows: International Association of Scientific Hydrology Bulletin, v. 16, no. 1, p. 69-87.

324. Duncan, A.C., Ugland, R.C., Kretschman, R.G., and Blattner, J.L., 1985, Water resources data, Colorado, water year 1984--v. 2, Colorado River Basin: U.S. Geological Survey Water-Data Report CO-84-2, 235 p.

325. Durfor, C.N., and Becker, Edith, 1964, Chemical quality of public water supplies of the United States and Puerto Rico, 1962, shown as Statewide averages, mainly in graphic and tabular form: U.S. Geological Survey Hydrologic Investigations Atlas HA-200.

326. Dutt, G.R., and Hendricks, D.M., 1983, Aquatic resources management of the Colorado River ecosystem, in Adams, V.D., and Lamarra, V.A., eds., Aquatic resources management of the Colorado River ecosystem, proceedings of the 1981 symposium, Las Vegas, Nevada, November 16-18, 1981: Ann Arbor, Mich., Ann Arbor Science Publishers, p. 475-490.

327. Ebens, R.J., and Shacklette, H.T., 1982, Geochemistry of some rocks, mine spoils, stream sediments, soils, plants, and waters in the western energy region of the conterminous United States, with sections on Field studies, by B.M. Anderson, J.G. Boerngen, J.J. Connor, W.E. Dean, J.A. Erdman, G.L. Feder, L.P. Gough, J.R. Herring, T.K. Hinkley, J.R. Keith, R.W. Klusman, J.M. McNeal, C.D. Ringrose, R.C. Severson, and R.R. Tidball: U.S. Geological Survey Professional Paper 1237, 173 p.

328. Ecker, R.M., 1984, Effects of rock riprap design parameters on flood protection costs for uranium tailings impoundments: U.S. Nuclear Regulatory Commission Report PNL-5068, 89 p. [Available from National Technical Information Service, Springfield, VA 22161 as NTIS Report NUREG/CR-3751.]

This report examines the costs of rock riprap flood protection for design flood events at two uranium tailings impoundments in western Colorado. The two sites are the Grand Junction impoundment located along the Colorado River and the Slickrock impoundment located along the Dolores River. The sensitivity of rock type, embankment side slope, and various safety factors is evaluated for six design flood events at Grand Junction and one flood event at Slickrock. The safety factor method of riprap design is used for cost comparison.

329. Ecker, R.M., Walters, W.H., and Skaggs, R.L., 1979, Hydrologic monitoring program, Rifle Oil Shale Facility, Colorado: Richland, Wash., Pacific Northwest Laboratory Report PNL-3220. 
330. Eckhardt, D.W., and Litke, D.W., 1988, Estimation of reservoir surface areas using satellite imagery, upper Gunnison River Basin, in Waterstone, M., and Burt, R.J., eds., Proceedings of the symposium on water-use data for water resources management: Bethesda, Md., American Water Resources Association Technical Publication Series TPS-88-2, p. 691-702.

331. Ecology Consultants, Inc., 1978, Capture locations of rare fish in the Upper Colorado River system, final report: U.S. Fish and Wildlife Service Report FWS/OBS-78/32, 44 p.

332. Economic Research Service, 1962, Water and related land resources, Gunnison River Basin, Colorado--A report based on a cooperative study by Colorado Water Conservation Board and the United States Department of Agriculture: Salt Lake City, Utah, prepared by Economic Research Service and U.S. Department of Agriculture, Forest Service and Soil Conservation Service, $103 \mathrm{p}$.

333. Eddy, R.M., and Fox, R.L., 1977, Green Mountain Reservoir-Lower Blue River study, Colorado, September, 1976: U.S. Environmental Protection Agency Report EPA-908/2-77-003, 100 p. [Available from National Technical Information Service, Springfield, VA 22161 as NTIS Report PB-80 159 528.]

During September, 1976, a study was conducted by the Environmental Protection Agency, Region VIII, to determine existing nutrient and organic loadings to Green Mountain Reservoir, present trophic status of the reservoir, and possible effects of increased nutrient addition on algal growth potential. Sampling was conducted during a four day period, with additional samples collected in November, 1976.

334. Edmondson, C.H., 1912, Protozoa of high mountain lakes in Colorado: Boulder, Colo., University of Colorado Stud. Ser. A, v. 9, p. 65-74.

335. Eisenhauer, R.J., 1982, Characteristics and applications of Big Sandy River, Glenwood Springs, and Dotsero Springs waters in energy development: Bureau of Reclamation Report REC-ERC$82-12,30$ p. [Available from National Technical Information Service, Springfield, VA 22161 as NTIS Report PB-83 111310.1

The Bureau of Reclamation is conducting studies to find methods for preventing high salinity point source waters from entering the Colorado River. There are three point sources that contribute a combined salt load of 344,700 metric tons per year. Big Sandy River contributes 117,900 metric tons per year, Glenwood Springs contribute 163,300 metric tons per year, and Dotsero Springs contribute 63,500 metric tons per year. Water analyses of the three saline point sources were made, and the water was used in simulating coal slurry transport by pipeline. This study has confirmed some aspects of the proposed methods for disposal of these waters (deep well injection or by use in energy development).

336. Eisenhauer, R.J., 1983, Characterization of Glenwood Springs and Dotsero Springs waters: Bureau of Reclamation Report REC-ERC-83-10, 58 p. [Available from National Technical Information Service, Springfield, VA 22161 as NTIS Report PB-84 134 501.]

The Bureau of Reclamation is conducting studies to find disposal methods for preventing high salinity water from 16 identified sources from entering the Colorado River. The Glen-Dot (Glenwood Springs-Dotsero Springs) is one source that 
contributes 10 percent of the identified salt load or 227,000 metric tons annually. Basic data on physical and chemical properties of the Glen-Dot waters were needed for determining methods of disposal. Consequently, a site sampling and analytical program was conducted from 1972 to 1982 by the Bureau. The analytical data obtained were evaluated to characterize Glen-Dot aquifers for physical properties, major constituents, trace metals, trace anions, radioactivity, and organic compounds.

337. Eisenhuth, H.P., 1968, Index of surface-water records to September 30, 1967--Part 9, Colorado River Basin: U.S. Geological Survey Circular 579, 53 p. [Also published in 1965 for surfacewater records to December 31, 1963 as U.S. Geological Survey Circular 509, 49 p.]

338. El-Ashry, M.T., 1978, Ground water salinity problems related to irrigation in the Colorado River Basin [abs.]: EOS, American Geophysical Union Transactions, v. 59, no. 12, p. 1064.

340. El-Ashry, M.T., 1980, Ground-water salinity problems related to irrigation in the Colorado River Basin: Ground Water, v. 18, no. 1, p. 37-45.

The groundwater system in many of the irrigated areas of the Colorado River Basin is derived almost entirely from deep percolation of irrigation water and seepage from irrigation conveyance and tail-water collection systems. Salt pickup rates from irrigated soils in the basin vary in the different areas. Among the high salt pickup areas is the Grand Valley in western Colorado, estimated at 8 tons/acre/year. Water entering the groundwater supply from irrigation practices in the valley amounts to about 145,000 acre-feet/year and contributes about 690,000 tons/year to the salt load of the Colorado River. Samples of base-flow water from the weathered Mancos Shale aquifer in the valley vary in salinity from about 1,500 to about $9,000 \mathrm{mg} / \mathrm{L}$ with a mean of $4,100 \mathrm{mg} / \mathrm{L}$, while water samples from alluvial aquifers range from 305 to $124,000 \mathrm{mg} / \mathrm{L}$ with a mean of about $11,500 \mathrm{mg} / \mathrm{L}$. Base-flow returning to the river in the drains and washes has concentrations that average about $4,200 \mathrm{mg} / \mathrm{L}$. Water losses and quantities of irrigation return flows can be reduced by improving farm irrigation efficiencies and by partial or complete lining of canals, laterals, and ditches. Increasing on-farm irrigation efficiency through system improvements and irrigation scheduling is the most cost-effective measure. However, achievement of higher efficiencies will require changes in water laws to encourage conservation and revised water pricing policies that discourage waste.

341. El-Ashry, M.T., 1980, Physical and ecological aspects of the Upper Colorado River Basin, a discussion, in Spofford, W.O., Jr., Parker, A.L., and Kneese, A.V., eds., Energy development in the Southwest, problems of water, fish and wildlife in the Upper Colorado River Basin, volume 1: Washington, D.C., Resources for the Future, Research Paper R-18, p. 68-78.

342. El-Ashry, M.T., 1985, Irrigation return flows and salinity problems in the Colorado River Basin, in Perspectives on nonpoint source pollution, proceedings of a national conference, Kansas City, Missouri, May 19-22, 1985: Washington, D.C., U.S. Environmental Protection Agency, p. $495-496$.

Soil and water salinity occur in arid regions wherever irrigation is practiced. In the United States, an estimated $20 \%$ of all irrigated land, about 4 million ha (10 million acres), suffer from salt-caused yield reductions. Salinity constitutes the most serious water quality problem in the western United States. In the U.S., the Colorado River 
Basin contains more major salinity problem areas than any other river basin in the western United States. Land degradation and reduced agricultural productivity are some of the likely downstream effects of high salt content in irrigation water. In all affected river basins, salinity has progressively increased as the water resources have been developed and put into use. The water in these rivers becomes increasingly saline from the headwaters to the mouths, mostly from seepage and return flows from irrigated land. In the Colorado River, salinity concentrations increase from $<50 \mathrm{mg} / \mathrm{L}$ in the headwaters to about $900 \mathrm{mg} / \mathrm{L}$ at Imperial Dam to about $1,200 \mathrm{mg} / \mathrm{L}$ in Mexico.

343. Elliott, J.G., 1988, Regionalization of mean annual suspended-sediment loads in streams; central, northwestern, and southwestern Colorado: U.S. Geological Survey Water-Resources Investigations Report 87-4193, 24 p.

Regression analysis was used to develop models for estimating mean annual suspended-sediment loads for streams in Colorado. Mean annual suspendedsediment loads at 81 selected streamflow-gaging stations in the central, northwestern, and southwestern regions of Colorado were expressed as functions of geomorphic and hydrologic variables. A multiple-regression model that included mean basin elevation, mean annual streamflow, and drainage-basin area explained 78 percent of the variance in mean annual suspended-sediment load when all sites were analyzed together. The State was divided into four regions to decrease variance from spatial differences in geography and climate, and multiple-regression models were recomputed for each region. The best multiple-regression models for the central, northwestern, and southwestern regions of Colorado included mean annual streamflow and mean basin elevation. A multiple-regression model was not developed for eastern Colorado because few sites in this region had adequate sediment-load records. Regionalization of mean annual suspended-sediment loads resulted in improved multiple-regression models for the central, northwestern, and southwestern regions of Colorado. The regional multiple-regression models can be used to estimate mean annual suspended-sediment loads for other streams in these regions when mean annual streamflow and mean basin elevation are known. Regional regression models based only on drainage area were also developed, and they can be used to estimate mean annual suspended-sediment load when annual streamflow is unknown.

344. Elliott, J.G., and DeFeyter, K.L., 1986, Sediment-data sources and estimated annual suspendedsediment loads of rivers and streams in Colorado: U.S. Geological Survey Water-Resources Investigations Report 86-4344, 148 p.

345. Elliott, J.G., Jarrett, R.D., and Ebling, J.L., 1982, Annual snowmelt and rainfall peak-flow data on selected foothills region streams, South Platte River, Arkansas River, and Colorado River Basins, Colorado: U.S. Geological Survey Open-File Report 82-426, 90 p.

346. Elliott, J.G., Murphy, D.M., and Tucker, K.S., 1994, Resource management considerations in a changing physical environment--The Gunnison Gorge, Colorado, in Marston, R.A., and Hasfurther, V.R., eds., Proceedings, annual summer symposium of the American Water Resources Association, effects of human-induced changes on hydrologic systems, Jackson Hole, Wyoming, June 26-29, 1994: Bethesda, Md., American Water Resources Association Technical Publication Series TPS-94-3, p. 619-628. 
347. Elliott, J.G., and Parker, R.S., 1992, Potential climate-change effects on bed-material entrainment, the Gunnison Gorge, Colorado, in Herrmann, R., ed., Proceedings of the American Water Resources Association symposium on managing water resources during global change, Reno, Nevada, November 1-5, 1992: Bethesda, Md., American Water Resources Association Technical Publication Series TPS-92-4, p. 751-759.

348. Elliott, R.D., Hannaford, J.F., and Shaffer, R.W., 1973, Twelve basin investigation analysis of potential increases in streamflow resulting from modification of cold orographic clouds in selected river basins of the Western United States, volume I (final report, Aug. 15, 1972May 15, 1973): Goleta, Calif., North American Weather Consultants Report NAWC-15-18-1, 328 p. [Available from National Technical Information Service, Springfield, VA 22161 as NTIS Report PB-232 131/3.]

The volume presents the cloud seeding potential for increased streamflow from seven major river basins in the Western United States. These major basins include the Upper Colorado, Rio Grande, Truckee-Walker-Humboldt, Sacramento, North Platte, and Snake. October-April hourly precipitation data were associated with appropriate rawinsonde data and precipitation-cloud top temperature curves plotted. From the curves, critical temperatures (the dividing line between cloud top temperatures that are susceptible to seeding and those that are not) were determined for each massif within the major basin. The area of effect model was employed in determining predicted seeded precipitation cloud top temperature curves, and the predicted curves were fitted to the historical curves based on the predicted not seeded curve in the critical temperature and colder cloud top temperature range. The seeding potential was then calculated from the difference between the predicted curve and the observed historical curve, and the frequency of cases. With this input data, potential incremental streamflow was computed for the water years 1951-52 through 1970-71.

349. Elliott, R.D., Shaffer, R.W., Court, Arnold, and Hannaford, J.F., 1976, Colorado River Basin Pilot Project comprehensive evaluation report, five winter seasons, 1970-71 to 1974-75 (final report): Bureau of Reclamation Report ARI-76-1,650 p. [Available from National Technical Information Service, Springfield, VA 22161 as NTIS Report PB-262 057/3.]

The primary objectives of this evaluation have been to: (1) test the physical concepts of weather modification potential, and (2) test the practical weather modification potential for an operations program, as carried out in the Colorado River Basin Pilot Project during the five winters of 1970-71 through 1974-75. The first objective is approached through an investigation of nucleant dispersion based on wind flow, and analysis of precipitation and rawinsonde data that is essentially diagnostic in character, and an analysis of surface runoff related to precipitation. The second objective is carried out through detailed analyses of precipitation and other records for all five years of the pilot project operation. Conclusions and recommendations are presented which can serve as guidance material for planning orographic research projects.

350. Ellis, E.G., 1976, Surficial and environmental geology of part of the Upper Williams Fork River Basin, Colorado: Boulder, Colo., University of Colorado, Master's thesis, $66 \mathrm{p}$.

351. Ellis, M.M., 1914, Fishes of Colorado: Boulder, Colo., University of Colorado Studies, v. 11, p. 1-136. 
352. Elmore, T., Jakasch, J., and Downing, D., 1985, Point/nonpint source trading program for Dillon Reservoir and planned extensions for other areas, in Perspectives on nonpoint source pollution, proceedings of a national conference, Kansas City, Missouri, May 19-22, 1985: Washington, D.C., U.S. Environmental Protection Agency, p. 413-416.

353. Enartech, Inc., and Leaf, C., 1986, Homestake Project Phase II wetland baseline report, v. 2, surface water hydrology: Denver, Colo., ERO Resources Corp., 86 p.

354. Enartech, Inc., and Ward, J.R., 1986, Homestake Project Phase II wetland baseline report, v. 4, water quality: Denver, Colo., ERO Resources Corp., $70 \mathrm{p}$.

355. Energy and Resource Consultants, Inc., 1983, Water use and reuse opportunities and costs at oil shale plants: Bureau of Reclamation Report OWRT/RU-83/11, 241 p. [Available from National Technical Information Service, Springfield, VA 22161 as NTIS Report PB-85 157 410/XAB.]

Converting oil shale into fuels marketable through existing channels requires largescale mining and processing. The mining and processing operations will consume large amounts of water and will vary from plant to plant. Variations in types of resources and the products produced will lead to a variety of mining and processing schemes each with their own use patterns. This report describes several of these schemes, as well as their water use and waste production patterns, water treatment plant designs and costs, and opportunities for internal water reuse and recycling. The project analyzed the ways that water will be used and may be reused in oil shale plants located in the Upper Colorado River Basin.

356. Engberg, R.A., 1991, Concentration and distribution of selenium associated with irrigation drainage in the Western United States, in Kirby W.H., and Weiyan, Tan, comps., Proceedings of the United States--People's Republic of China bilateral symposium on droughts and arid-region hydrology, Tucson, Arizona, September 16-20, 1991: U.S. Geological Survey Open-File Report 91-244, p. 113-123.

357. Engberg, R.A., and Sylvester, M.A., 1993, Concentration, distribution, and sources of selenium from irrigated lands in Western United States: American Society of Civil Engineers, Journal of Irrigation and Drainage Engineering, v. 119, no. 3, p. 522-536.

358. Engelen, G.B., 1972, Two-year cycles in soil moisture recharge, snowpack, and streamflow in relation to atmospheric conditions (with special reference to the Upper Colorado River Basin), in Guidebook to the international symposia on the role of snow and ice in hydrology, September 6-20, 1972, Banff, Alberta: . Ottawa, Ontario, Canada, Canadian National Committee for the International Hydrological Decade, p. 895-914.

Mean regional values for soil moisture, snowpack and streamflow were calculated for consecutive years and seasons from 20-30 years' records for a mountainous area roughly covering the Upper Colorado River Basin. Soil moisture (and snowpack, streamflow and regional atmosphere) shows a cyclic alternation of high and low values. An autumn with less than average soil moisture in storage precedes a winter with high recharge and the position is reversed the following year. The two-year cycles are explained in terms of interactions of the hydrological subsystems with each other and with the major atmospheric circulation over the western USA. Deviations 
from the regional cyclical behavior are explained in terms of shifts and trends in the major atmospheric circulation patterns.

359. Engineering Consultants, Inc., 1976, Floodplain information report, Gunnison River/Tomichi Creek, Gunnison, Colorado: Denver, Colo., Colorado Water Conservation Board.

360. Engineering-Science, Inc., 1976, Wastewater treatment facilities, Granby Sanitation District, Granby, Colorado (final environmental impact statement): U.S. Environmental Protection Agency Report EPA-68-01-2392, 360 p. [Available from National Technical Information Service, Springfield, VA 22161 as NTIS Report PB-258 155.]

It has been proposed to construct new expanded wastewater treatment facilities to replace the existing plant, which serves some 600 permanent and about 1000 visitors in the Granby area. The proposal to build the new facility, with provisions for nitrification of effluent and with discharge to the Fraser River, was prompted by population growth projections mainly associated with a large proposed second home/ resort complex adjacent to Granby named Val Moritz. Environmental impacts and alternatives are presented.

361. Engineering-Science, Inc., 1986, Description of water quality baseline and potential water quality impacts associated with the Williams Fork Gravity Project: Omaha, Nebr., U.S. Army Corps of Engineers.

362. Enviro Control, Inc., 1976, Assessment of effects of altered streamflow characteristics on fish and wildlife, final report; volume II, Rocky Mountain case studies; task 3, analysis of case study findings, identification of problems and recommendations of remedies, U.S. Fish and Wildlife Service contract 14-16-0008-956: Rockville, Md., Enviro Control, Inc., various pagination.

Evaluation of streamflow methodologies and the associated recommendation process to preserve fish and wildlife through instream flow reservations. It contains data to assess the actual impacts on fish and wildlife of streamflow regulation by Granby, Shadow Mountain, and Willow Creek Dams (Bureau of Reclamation ColoradoBig Thompson Project) on the Colorado River.

363. Eppinger, R.G., Theobald, P.K., and Sutley, S.J., 1985, Map showing the distribution of selected mineral assemblages in nonmagnetic heavy-mineral concentrates from stream sediments from the Vasquez Peak Wilderness Study Area and the Williams Fork and St. Louis Peak Roadless Areas, Clear Creek, Grand, and Summit Counties, Colorado: U.S. Geological Survey Miscellaneous Field Studies Map MF-1588-F, scale 1:50,000.

364. Erlenkotter, D., and Sherer, C.R., 1977, An economic analysis of optimal investment scheduling for salinity control in the Colorado River (completion report): Bureau of Reclamation Report OWRT-B-170-CAL(5), 277 p. [Available from National Technical Information Service, Springfield, VA 22161 as NTIS Report PB-278 328/0.]

This study demonstrates the development of a comprehensive investment planning model for salinity control on the Colorado River for evaluation of alternative salinity control plans and determination of those plans that minimize total economic costs and damages. Sources of salinity, early modeling efforts, selected legal institutional factors and recent salinity control plans are reviewed. The planning model developed 
includes the relevant detail of deterministic simulation models for the Colorado and incorporates estimates of economic damages and project costs that may be drawn from other mathematical programming models for agricultural areas and salinity control sites. The model serves best as an information system for exploring the effects of costminimizing plans of different assumptions and data variations. Instead of relying on arbitrarily established salinity standards, the model determines future salinity levels or 'standards' by balancing costs and benefits of incremental additions to the salinity control plan.

365. Eustis, A.B., and Hillen, H.H., 1954, Stream sediment removal by controlled reservoir releases: Prog. Fish-Cult., v. 16, no. 1, p. 30-35.

366. Evangelou, V.P., 1981, Chemical and mineralogical composition and behavior of the Mancos Shale as a diffuse source of salts in the Upper Colorado River Basin: Davis, Calif., University of California, Ph.D. dissertation, 211 p. [Available from National Technical Information Service, Springfield, VA 22161 as NTIS Report PB-81 197 626.]

Previous investigations relative to salinity in the Upper Colorado River Basin have mostly dealt with the total quantities of dissolved solids moving into the Colorado River. The purpose of this investigation is to conduct a thorough study of mineralogical and chemical characteristics of Mancos Shale within the West Salt Creek watershed, Colorado. The investigation focuses on the Mancos Shale as a source of soluble components contributing to salinity of the Colorado River. The overall investigation has revealed the primary source of the salts. Salts are derived from carbonates, calcite and dolomite, which upon contact with sulfuric acid (produced by the biological oxidation of pyrite) produce gypsum and magnesium sulfates.

367. Evangelou, V.P., Whittig, L.D., and Tanji, K.K., 1984, Dissolved mineral salts derived from Mancos Shale: Journal of Environmental Quality, v. 13, no. 1, p. 146-150.

368. Evans, G.S., and Hailu, T., 1984, The impact of longwall mining on the hydrologic balance; premining data collection [abs.], in Moreland, J.A., and Van Voast, W.A., comps., Abstracts from the 13th annual Rocky Mountain ground-water conference, Great Falls, Montana, April 8-11, 1984: Butte, Mont., Bureau of Mines and Geology Special Publication 91, p. 52.

369. Evans, N.A., 1970, Salinity control in return flow from irrigated areas--A demonstration project, in Water quality management problems in arid regions: U.S. Federal Water Quality Administration Water Pollution Control Research Series 13030 DYY, p. 45-55.

370. Evans, N.A., 1973, Regional energy-water problems; Colorado River-Great Basin, in The role of water in the energy crisis, proceedings of a conference, Lincoln, Nebraska, Oct. 23-24, 1973, panel II: Lincoln, Nebr., Nebraska Water Resources Research Institute, p. 192-194.

371. Evans, N.A., 1975, Salt problem in the Colorado River: Natural Resources Journal, v. 15, no. 1, p. 55-62.

372. Evans, R.G., 1981, Optimizing salinity control strategies for the Upper Colorado River Basin: Fort Collins, Colo., Colorado State University, Ph.D. dissertation, 310 p. 
373. Evans, R.G., Walker, W.R., and Skogerboe, G.V., 1982, Optimal salinity control program for the Upper Colorado River Basin, in Water and energy development in an arid environment-The Colorado River Basin: Water Supply and Management, v. 6, no. 1-2, p. 169-197.

374. Evans, R.G., Walker, W.R., and Skogerboe, G.V., 1982, Optimizing salinity control strategies for the Upper Colorado River Basin (final report): U.S. Environmental Protection Agency Report EPA-600/2-82-077, 225 p. [Available from National Technical Information Service, Springfield, VA 22161 as NTIS Report PB-83 136 143.]

A simple multi-level nonlinear optimization procedure was utilized to formulate the most cost-effective array of salinity control strategies for the Upper Colorado River Basin. The incremental cost-effectiveness methodology qualitatively indicates the location and general type of alternatives to be implemented in a least-cost basin-wide salinity control program. The results also qualitatively indicated the anticipated salt load reduction and expected annual costs of each salinity reduction increase for any preselected level of control. Costs and salinity contributions associated with various alternatives were generated using January, 1980 estimated conditions. Marginal cost analysis based on current damage estimates indicate that the optimal cost-effective salinity control program in the Upper Basin would cost about $\$ 30$ million annually and remove about 1.2 million megagrams of salt per year.

375. Evans, R.G., Walker, W.R., and Skogerboe, G.V., 1983, Strategies for salinity control for the Upper Colorado River Basin: American Society of Agricultural Engineers Transactions, v. 26, no. 3, p. 738-742.

A multi-level nonlinear optimization procedure was utilized to develop an array of strategies for the most cost-effective salinity control program for the Upper Colorado River Basin. Cost effectiveness functions were developed for each point source control project for the major canals, aggregate laterals and selected on-farm improvements in each agricultural area designated in Public Law: 93-320. Marginal cost analysis showed that a cost-effective Upper Basin salinity control program would cost $\$ 30$ million annual and remove 1.2 million megagrams of salt each year.

Sensitivity analysis indicated that very large errors in costs and component salt contributions would have to be evident to change the order of the optimal salinity strategy. The results quantitatively indicate the location and general types of alternatives to be implemented and the associated annual costs for any selected level of basin-wide control.

376. Evans, R.G., Walker, W.R., Skogerboe, G.V., and Binder, C.W., 1978, Implementation of agricultural salinity control technology in Grand Valley (final report): U.S. Environmental Protection Agency Report EPA/600/2-78/160, 211 p. [Available from National Technical Information Service, Springfield, VA 22161 as NTIS Report PB-286 510/3.]

A summary of the results of applied research on salinity control of irrigation return flows in the Grand Valley of Colorado is presented for the period of 1969 to 1976. Salinity and economic impacts are described for the Grand Valley Salinity Control Demonstration Project which contains approximately 1,600 hectares and involves most of the local irrigation companies in the Valley. During the eight years of the demonstration project, $12.2 \mathrm{~km}$ of canals were lined, $26.54 \mathrm{~km}$ of laterals were lined, 16,400 meters of drainage tile were installed, a wide variety of on-farm improvements 
were constructed, and an irrigation scheduling program was implemented. On-farm improvements evaluated were solid-set sprinklers, side-roll sprinklers, drip (trickle) irrigation, furrow irrigation, and automatic cut-back furrow irrigation. The total value of the constructed improvements in the demonstration area was about $\$ 750,000$. The total improvements resulted in a salt reduction of 12,300 metric tons per year reaching the Colorado River. This salt reduction results in the annual benefit to downstream water users of nearly $\$ 2,000,000$. In addition, there are benefits to the local water users with increased crop yields and to the people of Grand Valley in increased business.

377. Evans, R.G., Walker, W.R., Skogerboe, G.V., and Smith, S.W., 1978, Evaluation of irrigation methods for salinity control in Grand Valley (final report): U.S. Environmental Protection Agency Report EPA/600/2-78/161, 189 p. [Available from National Technical Information Service, Springfield, VA 22161 as NTIS Report PB-286 511/1.]

Irrigation return flows in the Upper Colorado River Basin carry large salt loads as a result of contact with the saline soils and the marine derived geologic substratum. The Grand Valley of western Colorado is a major contributor to the salinity problems of the basin and is, therefore, a logical region to test the effectiveness of agricultural salinity control alternatives. This study emphasized the implementation of on-farm salinity control alternatives; primarily evaluating irrigation scheduling, furrow irrigation, sprinkler irrigation, and trickle irrigation. Border irrigation was also evaluated but was not implemented as part of this study. The cost-effectiveness of the various on-farm alternatives in the Grand Valley is summarized and presented in this report.

378. Evans, W.C., Presser, T.S., and Barnes, Ivan, 1987, Selected soda springs of Colorado and their origins, in Subitzky, Seymour, ed., Selected papers in the hydrologic sciences 1986:

U.S. Geological Survey Water-Supply Paper 2310, p. 45-52.

379. Everhart, W.H., and Seaman, W.R., 1971, Fishes of Colorado: Denver, Colo., Colorado Game, Fish and Parks Division, 75 p.

380. Faulkner, H., 1994, Spatial and temporal variation of sediment processes in the alpine semi-arid basin of Alkali Creek, Colorado, USA: Geomorphology, v. 9, no. 3, p. 203-222.

381. Feast, C.N., 1954, Project report--Grand Lake, Shadow Mountain Reservoir and Granby Reservoir fish management investigations: Denver, Colo., Colorado Department of Game and Fish, 24 p.

382. Federal Emergency Management Agency, 1985, Firm flood insurance rate map, city of Gunnison, Colorado, Gunnison County: Denver, Colo., National Flood Insurance Program.

383. Federal Emergency Management Agency, 1989, Flood insurance study--Gunnison County, Colorado, unincorporated areas: Washington, D.C.[?], Federal Emergency Management Agency, $13 \mathrm{p}$.

384. Fellows, A.L., 1902, Water resources of the State of Colorado: U.S. Geological Survey Water-Supply Paper 74, 151 p. 
385. Fellows, A.L., 1903, The Gunnison Tunnel: Forestry and Irrigation, v. 9.

386. Fellows, A.L., 1904, Investigations in Colorado: U.S. Reclamation Service Annual Report 2, p. $162-250$.

387. Fellows, A.L., 1905, Reclamation operations in Colorado: U.S. Reclamation Service Annual Report 3.

388. Feth, J.H., 1965, Calcium, sodium, sulfate, and chloride in stream water of the western conterminous United States to 1957: U.S. Geological Survey Hydrologic Investigations Atlas HA-189, 4 sheets, scale 1:2,500,000.

389. Feth, J.H., and others, 1965, Preliminary map of the conterminous United States showing depth to and quality of shallowest ground water containing more than 1,000 parts per million dissolved solids: U.S. Geological Survey Hydrologic Investigations Atlas HA-199, 2 sheets, scale 1:3,168,000, 31 page text included.

390. Ficke, J.F., Adams, D.B., and Danielson, T.W., 1977, Evaporation from seven reservoirs in the Denver water-supply system, central Colorado: U.S. Geological Survey Water-Resources Investigations 76-114, 170 p. [Available from National Technical Information Service, Springfield, VA 22161 as NTIS Report PB-265 323.]

391. Ficklin, W.H., Smith, C.L., and Motooka, J.M., 1986, Analytical results for 38 hot spring samples collected in the Western United States: U.S. Geological Survey Open-File Report 86-283, 3 p.

392. Fifield, J.S., 1980, Watershed constituent loading analysis utilizing empirical hydrochemical modeling techniques: Logan, Utah, Utah State University, Ph.D. dissertation, $206 \mathrm{p}$.

393. Finnell, L.M., 1961-1963, Granby Reservoir fish management studies: Denver, Colo., Colorado Department of Game and Fish Job Progress Report, 1961-62 (1 v.), 27 p.; 1963, 17 p.

394. Finnell, L.M., Bennett, G.L., Griest, J., and Gregg, R., 1975, Fryingpan-Arkansas fish research investigations: Colorado Division of Wildlife Project Report 4, 23 p.

395. Fischer, R.C., 1974, Colorado oil shale and water: Colorado School of Mines Quarterly, v. 69, no. 2, p. 133-139.

396. Flack, J.E., and Howe, C.W., eds., 1974, Salinity in water resources, proceedings of the 15th annual Western Resources Conference, July 1973, University of Colorado: Boulder, Colo., Merriman, $177 \mathrm{p}$.

397. Fleischer, Michael, 1962, Fluoride content of ground water in the conterminous United States (maximum reported value for each county): U.S. Geological Survey Miscellaneous Geologic Investigations Map I-387, scale 1:5,000,000.

398. Flinckinger, S.A., Norton, V.C., and Brandau, W.F., 1973, Further aquatic biology investigations on Parachute Creek and tributaries, environmental impact analysis, appendix 10: Atlantic Richfield Company, $65 \mathrm{p}$.

399. Florquist, B.A., 1973, Techniques for locating water wells in fractured crystalline rocks: Ground Water, v. 11, no. 3, p. 26-28. 
400. Flug, M., 1977, Optimal energy-water-salinity strategies, Upper Colorado River Basin: Fort Collins, Colo., Colorado State University, Ph.D. dissertation, 223 p.

401. Flug, M., 1979, Impacts of water use efficiency on energy development: Water Resources Bulletin, v. 15, no. 6, p. 1743-1752.

To help meet national energy demands, interest has been focused on the coal, oil shale, and uranium deposits of the Upper Colorado River Basin. Several energy output projections for the basin have been presented based upon water availability. Inherent in all these analyses are estimates as to the rate of water use in each energy

development. New energy technologies are characterized by parameters extrapolated from small scale energy facilities. The data provide projected costs, conversion efficiencies, and material inputs and outputs. Alternative techniques for process cooling and solids handling provide variable rates of water use which affect other conversion parameters. Results from a mathematical model are used in analyzing the sensitivity of an optimal energy development strategy for the Upper Colorado River Basin. The impacts of alternative water use rates are investigated in terms of net energy output, total cost, and displacements in the development strategy. Similarly, controls and regulations on energy resource development are evaluated.

402. Flug, M., Walker, W.R., and Skogerboe, G.V., 1979, Energy-water-salinity--Upper Colorado River Basin: American Society of Civil Engineers, Journal of Water Resources Planning and Management Division, v. 105, no. WR2, p. 305-315.

403. Flug, M., Walker, W.R., and Skogerboe, G.V., 1979, Optimal water use and salinity control for energy--Upper Colorado River Basin: Water Resource Bulletin, v. 15, no. 4, p. 964-973.

A mathematical model has been developed to assess the relationships among Colorado River Basin water availability, salinity, energy production, and the economics of development. Alternative scenarios regarding synthetic fuel production are evaluated in terms of differential energy development costs, various institutional constraints, and restrictions pertaining to water use and water quality degradation. A primary concern is the salt concentration in the Lower Colorado River Basin.

404. Flug, M., Walker, W.R., and Skogerboe, G.V., 1982, Impact of energy development upon water and salinity in the Upper Colorado River Basin, in Water and energy development in an arid environment--The Colorado River Basin: Water Supply and Management, v. 6, no. 1-2, p. 199-220.

405. Flug, M., Walker, W.R., Skogerboe, G.V., and Smith, S.W., 1977, The impact of energy development on water resources in the Upper Colorado River Basin: Fort Collins, Colo., Colorado State University.

406. Follansbee, Robert, 1922, Some characteristics of run-off in the Rocky Mountain region, chap. C of Contributions to the hydrology of the United States, 1921: U.S. Geological Survey WaterSupply Paper 500, p. 55-74.

407. Follansbee, Robert, 1929, Upper Colorado River and its utilization: U.S. Geological Survey Water-Supply Paper 617, 394 p. 
408. Follett, R.H., Kendall, P.A., Doherty, T.J., Williamson, C.E., Golus, H.M., and Stack, M.W., 1990, Selenium levels found in soil, water, vegetable and field crop samples in western Colorado: Fort Collins, Colo., Colorado State University Technical Bulletin LTB90-2, 12 p.

409. Fortier, S., and Blaney, H.F., 1928, Silt in the Colorado River and its relation to irrigation: U.S. Department of Agriculture Technical Bulletin 6795.

410. Four Corners Environmental Research Institute, 1976, Biological and chemical studies of selected reaches and tributaries of the Colorado River in the State of Colorado: Denver, Colo., Colorado Department of Health, 103 p.

411. Fox, F.M., and Associates, 1974, Roaring Fork and Crystal Valleys--An environmental and engineering geology study, Eagle, Garfield, Gunnison, and Pitkin Counties, Colorado: Denver, Colo., Colorado Geological Survey, Environmental Geology 8, 64 p.

412. Fradkin, P.L., 1981, A river no more, the Colorado River and the West: New York, N.Y., Alfred A. Knopf, 360 p.

413. Frank, E.C., 1973, Snow amount in relation to streamflow and herbage production in western Colorado: Journal of Range Management, v. 26, p. 32-34.

414. Frank, E.C., Brown, H.E., and Thompson, J.R., 1975, Hydrology of Black Mesa watersheds, western Colorado: U.S. Department of Agriculture, Forest Service General Technical Report RM-13, 11 p.

415. Freeman, D.M., and Brown, P.J., 1974, Concepts of carrying capacity and planning in complex ecological systems, in Crawford, A.B., and Peterson, D.F., eds., Environmental management in the Colorado River Basin: Logan, Utah, Utah State University Press, p. 281-297.

416. Freeman, L.R., 1923, The Colorado River--Yesterday, today and tomorrow: New York, N.Y., Dodd, Mead, and Company.

417. Freethey, G.W., 1969, Hydrogeologic evaluation of pollution potential in mountain dwelling sites (Colorado): Fort Collins, Colo., Colorado State University, Master's thesis.

418. Freethey, G.W., 1988, Lithologic and hydrologic properties of Mesozoic rocks in the Upper Colorado River Basin, in McLean, J.S., and Johnson, A.I., eds., Regional aquifer systems of the United States--Aquifers of the western mountain area, American Water Resources Association 23rd annual conference and symposium, Salt Lake City, Utah, November 1-6, 1987: Bethesda, Md., American Water Resources Association Monograph Series 14, p. 81-99.

419. Freethey, G.W., 1988, Upper Colorado River Basin Regional Aquifer-System Analysis-Mesozoic rocks in Colorado, Utah, Wyoming, Arizona, and New Mexico, in McLean, J.S., and Johnson, A.I., eds., Regional aquifer systems of the United States--Aquifers of the western mountain area, American Water Resources Association 23rd annual conference and symposium, Salt Lake City, Utah, November 1-6, 1987: Bethesda, Md., American Water Resources Association Monograph Series 14, p. 57-70. 
420. Freethey, G.W., and Cordy, G.E., 1991, Geohydrology of Mesozoic rocks in the Upper Colorado River Basin in Arizona, Colorado, New Mexico, Utah, and Wyoming, excluding the San Juan Basin: U.S. Geological Survey Professional Paper 1411-C, 118 p.

Rocks of Mesozoic age in the Upper Colorado River Basin underlie parts of five states west of the Continental Divide - Arizona, Colorado, New Mexico, Utah, and Wyoming. These rocks consist of conglomerate, sandstone, shale, siltstone, claystone, limestone, and evaporites that have been folded, fractured, and faulted by large-scale tectonic activities that created several large structural basins and uplifts. As of 1987, ground water withdrawals from these rocks throughout the region have been small, except in some localized areas. The Mesozoic rocks consist of 10 geohydrologic units - 5 aquifers separated by 5 confining units. Ground water recharge occurs along the margins of uplifts at higher altitudes, where precipitation is greatest and rocks are exposed. Ground water flows laterally through interconnected pores and fractures in the rock from areas of high to areas of low hydraulic head. Ground water moves vertically between aquifers through confining units in response to differences in hydraulic head in adjacent aquifers. Discharge occurs in the main surface drainage network from rocks exposed in canyon walls cut by streams. Recoverable ground water in storage of suitable quality for most uses is estimated to be 530 million acrefeet, about 4 percent of the total volume in storage. Hydrologic properties of the rocks vary laterally because of changing lithofacies within a geologic formation, stratigraphic intertonguing between formations, and erosional pinchouts of formations. In general, water in the Mesozoic rocks is fresh in the southern half of the study areas, where the aquifers are exposed and easily recharged. Water generally is very saline to briny in the northern half, where the aquifers are confined beneath thick overburden and are distant from recharge areas. Sodium chloride water having a dissolved-solids concentration in excess of $35,000 \mathrm{mg} / \mathrm{L}$ is present in deep structural basins; calcium carbonate water having a dissolved-solids concentration of $<2,000 \mathrm{mg} / \mathrm{L}$ generally is present where aquifers are at shallow depths.

Concentrations of iron and manganese generally are large in water from all geohydrologic units, whereas concentrations of other minor constituents are large only locally. Use of the ground water is limited by deep burial, small transmissivity, and the presence of saline water in many areas.

421. Freethey, G.W., Kimball, B.A., Wilberg, D.E., and Hood, J.W., 1984, General hydrogeology of the aquifers of Mesozoic age, Upper Colorado River Basin, excluding the San Juan Basin; Colorado, Utah, Wyoming, and Arizona: U.S. Geological Survey Open-File Report 84-716, 27 p.

422. Freethey, G.W., Kimball, B.A., Wilberg, D.E., and Hood, J.W., 1988, General hydrogeology of the aquifers of Mesozoic age, Upper Colorado River Basin, excluding the San Juan Basin; Colorado, Utah, Wyoming, and Arizona: U.S. Geological Survey Hydrologic Investigations Atlas HA-698, 2 sheets, scale 1:2,500,000.

423. French, R.H., ed., 1984, Salinity in watercourses and reservoirs, proceedings of the 1983 international symposium on state-of-the-art control of salinity, Salt Lake City, Utah, July 13-15, 1983: Stoneham, Mass., Butterworth Publishers, 622 p. 
424. Frevert, D.K., Fontane, D.G., Lane, W.L., Schuster, R.J., Cowan, M., and Vudhivanich, V., 1985, Institutional constraints and evaluation of potential management strategies on the Colorado River system, in Proceedings of the 1985 ASCE National Conference on Irrigation and Drainage, San Antonio, Texas: American Society of Civil Engineers, p. 198-209.

Management of the Colorado River reservoir system is a complex problem influenced by a number of institutional constraints including interstate compact agreements, international treaties, power supply commitments, and flood control requirements. Although reservoir management decisions are constrained by these factors, some flexibility for these decisions remains and their ramifications are far reaching. Thus, it is important to understand how potential management strategies affect reservoir releases, contents, power generation, and other factors which impact on the agencies, districts, and other entities which depend on this system for their supplies. This paper describes a coordinated study that used two computer models to compare various management strategies.

425. Fuller, M.L., Clapp, F.G., and Johnson, B.L., 1906, Bibliographic review and index of underground-water literature published in the United States in 1905: U.S. Geological Survey Water-Supply Paper 163, 130 p.

426. Fullerton, W.T., and Long, S.G., 1989, Wetland creation in a river valley disturbed by dredge boat mining, in Fisk, D.W., ed., Proceedings of the symposium on wetlands--Concerns and successes, Tampa, Florida, September 17-22, 1989: Bethesda, Md., American Water Resources Association Technical Publication Series TPS-89-3, p. 297-306.

427. Galyean, K.C., Adams, D.B., and Collins, D.L., 1985, Hydrologic data from Naval Oil Shale reserves, Parachute Creek Basin, northwestern Colorado, 1980-81: U.S. Geological Survey Open-File Report 83-858, 70 p.

428. Galyean, K.C., Jenkins, R.A., and Collins, D.L., 1985, Hydrologic data from Naval Oil Shale reserves, Parachute Creek Basin, northwestern Colorado, water years 1982-83: U.S. Geological Survey Open-File Report 85-647, 91 p.

429. Gannett, Henry, 1877, Topographic report on the Grand River District in Hayden, F.V., Ninth annual report of the United States Geological and Geographical Survey of the Territories, embracing Colorado and parts of adjacent territories, being a report of progress of the exploration for the year 1875: U.S. Geological and Geographical Survey of the Territories (Hayden) Annual Report 9, p. 335-350.

431. Gardner, B.D., and Stewart, C.E., 1975, Agriculture and salinity control in the Colorado River Basin: Natural Resources Journal, v. 15, no. 1, p. 63-81.

432. Gardner, B.D., and Stewart, C.E., 1978, Agriculture and salinity, in Peterson, D.F., and Crawford, A.B., eds., Values and choices in the development of the Colorado River Basin: Tucson, Ariz., University of Arizona Press, p. 121-143.

The interactions of salt, agriculture, and irrigation in the Colorado River Basin are discussed. The effects of salt on crops are summarized. Several options for bringing salinity production under control by litigation or by imposing standards or economic 
incentives are detailed. The various proposed programs for water quality control in the basin are discussed.

433. Gardner, R.L., and Young, R.A., 1988, Assessing strategies for control of irrigation-induced salinity in the Upper Colorado River Basin: American Journal of Agricultural Economics, v. 70, no. 1 , p. 37-49.

Dissolved mineral salts (salinity) adversely affects numerous urban and agricultural users of Colorado River water in southwestern United States and in Mexico. More than a third of the salt load is thought to be induced by drainage from irrigated lands onto highly saline groundwater deposits in the Upper Colorado Basin in Colorado, Utah, and Wyoming. Various public policy initiatives are proposed to induce farmers to reduce discharges of this nonpoint pollutant. Taxes of water, water conservation subsidies, and land and water rights purchases are analyzed in a linear programming framework. The allocative efficiency and the distribution of control costs and damages among irrigators, water uses, and taxpayers are assessed.

434. Garland, T.R., Wildung, R.E., and Zachara, J.M., 1988, A case study of the effects of oil shale operations on surface and groundwater quality--I, Sources of contamination and hydrologic controls on water composition: Journal of Environmental Quality, v. 17, no. 4, p. 653-659.

435. Garland, T.R., Zachara, J.M., and Wildung, R.E., 1988, A case study of the effects of oil shale operations on surface and groundwater quality--II, Major inorganic ions: Journal of Environmental Quality, v. 17, no. 4, p. 660-666.

The distribution of the major inorganic ions in surface and groundwater, as related to substrata and hydrologic phenomena, was determined in a semiarid watershed representing an important area of oil shale development in northwestern Colorado. Surface and alluvial groundwaters were analyzed with time over a period of 1 yr, both upstream and downstream of an unengineered oil shale disposal site, providing unique insight into the chemical and hydrologic controls on the composition of major ions in ground and surface waters. The primary dissolved species in the surface and groundwaters above and below the disposal site were $\mathrm{Na}^{+}, \mathrm{Mg}^{2+}, \mathrm{Ca}^{2+}, \mathrm{SO}_{4}^{2-}$, and $\mathrm{HCO}_{3}^{-}$.

436. Garstka, W.U., Love, L.D., Goodell, B.C., and Bertle, F.A., 1958, Factors affecting snowmelt and streamflow, Fraser Experimental Forest, 1946-53: Fort Collins, Colo., Bureau of Reclamation and U.S. Department of Agriculture, Forest Service, 189 p.

437. Gatewood, J.S., 1956, Index of surface-water records to September 30, 1955, part 9, Colorado River Basin: U.S. Geological Survey Circular 389, 31 p.

438. Gaydos, M.W., 1980, Summary of water-quality data for selected streams in Colorado: U.S. Geological Survey Open-File Report 80-682, 148 p.

439. Geldon, A.L., 1988, Ground-water systems in Paleozoic rocks of the Upper Colorado River Basin, Arizona, Colorado, Utah, and Wyoming [abs.]: Geological Society of America Abstracts with Programs, v. 20, no. 7, p. 172. 
440. Geldon, A.L., 1988, Hydrostratigraphic characterization of Paleozoic formations in the Upper Colorado River Basin, in McLean, J.S., and Johnson, A.I., eds., Regional aquifer systems of the United States--Aquifers of the western mountain area, American Water Resources Association 23rd annual conference and symposium, Salt Lake City, Utah, November 1-6, 1987: Bethesda, Md., American Water Resources Association Monograph Series 14, p. 135-159.

441. Geldon, A.L., 1988, Porosity and permeability of the Paleozoic rocks in the Upper Colorado River Basin, Arizona, Colorado, New Mexico, Utah, and Wyoming, in McLean, J.S., and Johnson, A.I., eds., Regional aquifer systems of the United States--Aquifers of the western mountain area, American Water Resources Association 23rd annual conference and symposium, Salt Lake City, Utah, November 1-6, 1987: Bethesda, Md., American Water Resources Association Monograph Series 14, p. 171-190.

442. Geldon, A.L., 1989, Hydrogeology of the Leadville Limestone and other Paleozoic rocks in northwestern Colorado, with results of aquifer tests at Glenwood Springs: U.S. Geological Survey Water-Resources Investigations Report 87-4195, 96 p.

443. Geldon, A.L., 1989, Hydrologic data for Paleozoic rocks in the Upper Colorado River Basin, Colorado, Utah, Wyoming, and Arizona; Regional Aquifer-System Analysis Program: U.S. Geological Survey Open-File Report 89-59, 219 p.

444. Gellis, A.C., 1988, Decreasing sediment and salt loads in the Colorado River Basin--A response to arroyo evolution: Fort Collins, Colo., Colorado State University, Master's thesis.

445. Gellis, A.C., Hereford, Richard, and Schumm, S.A., 1989, Geomorphic and hydrologic control of sediment and salt loads in the Colorado River Basin--Significance for conservation and land management: U.S. Geological Survey Open-File Report 89-121, 37 p.

446. Gellis, A.C., Hereford, Richard, Schumm, S.A., and Hayes, B.R., 1991, Channel evolution and hydrologic variations in the Colorado River Basin--Factors influencing sediment and salt loads: Journal of Hydrology, v. 124, no. 3-4, p. 317-344.

Suspended-sediment and dissolved-solid (salt) loads decreased after the early 1940s in the Colorado Plateau portion of the Colorado River Basin, although discharge of major rivers - the Colorado, Green and San Juan - did not change significantly. This decline followed a period of high sediment yield caused by arroyo cutting. Reduced sediment loads have previously been explained by a change in sediment sampling procedures or changes in climate, land-use and conservation practices. More recent work has revealed that both decreased sediment production and sediment storage in channels of tributary basins produced the decline of sediment and salt loads.

Sediment production and sediment storage are important components of incisedchannel evolution, which involves sequential channel deepening, widening and finally floodplain formation. Accordingly, the widespread arroyo incision of the late nineteenth century resulted initially in high sediment loads. Since then, loads have decreased as incised channels (arroyos) have stabilized and begun to aggrade. However, during the 1940s, a period of low peak discharges permitted vegetational colonization of the valley floors, which further reduced sediment loads and promoted channel stabilization. This explanation is supported by experimental studies and field observations. Both geomorphic and hydrologic factors contributed to sediment storage and decreased sediment and salt loads in the Upper Colorado River Basin. 
447. Gellis, A.C., and Schumm, S.A., 1988, Decreasing sediment and salt loads in the channels of the Colorado Plateau--A response to arroyo evolution [abs.]: EOS, American Geophysical Union Transactions, v. 69 , no. 18 , p. 567.

448. General Accounting Office, 1979, Colorado River Basin water problems--How to reduce their impact (report to the Congress): General Accounting Office Report CED-79-11, 149 p.

[Available from National Technical Information Service, Springfield, VA 22161 as NTIS Report PB-295 398/2.]

This report describes the numerous water problems existing within the Colorado River Basin and discusses the need for the states and the federal government to work together to solve these problems.

449. George, R.D., Curtis, H.A., Lester, O.C., Crook, J.S., Yeo, J.B., and others, 1920, Mineral waters of Colorado: Denver, Colo., Colorado Geological Survey Bulletin 11, 474 p.

450. Gernerd, K.A., 1986, Water availability for energy development in the Upper Colorado River Basin, in Roluti, M.J., ed., Water Power '85, proceedings of an international conference on hydropower, Las Vegas, Nevada, September 25-27, 1985: New York, N.Y., American Society of Civil Engineers, p. 2153-2158.

The Bureau of Reclamation is investigating, for planning purposes through hydrologic determination, the total allowable depletion level in the Upper Colorado River Basin. The Colorado River Simulation System (CRSS) computer model and methodology were used extensively to study the ability of the Upper Basin to meet varying depletion level demands under different reservoir delivery schedules. The state-ofthe-art CRSS computer model and methodology verifies that the existing 5.8 million acre-feet depletion level for the Upper Colorado River Basin is conservative. Without stressing the Upper Colorado River system, the model generates a depletion number that is approximately 5 percent higher for the Upper Colorado River Basin. It appears that development is possible without interfering with existing users or proposed water projects through the year 2040 .

451. Gernerd, K.A., Messer, J.J., Post, F.J., and Lamarra, V.A., 1983, Assessing the effects of coal mining and related energy development on aquatic environmental quality in the Upper Colorado Basin, in Adams, V.D., and Lamarra, V.A., eds., Aquatic resources management of the Colorado River ecosystem, proceedings of the 1981 symposium, Las Vegas, Nevada, November 16-18, 1981: Ann Arbor, Mich., Ann Arbor Science Publishers, p. 383-397.

452. Gertsch, W.D., Sathaye, J., Ritschard, R., and Parker, S., 1977, Water requirements for future energy development in the West--State perspectives: Energy Research and Development Administration, 57 p. [Available from National Technical Information Service, Springfield, VA 22161 as NTIS Report LA-6688-MS.]

This survey for the U.S. Water Resources Council presents a summary of state views on the sufficiency of western water resources for energy development in the West. Possible impacts and problems associated with the commitment of water to energy use are also identified for California, Colorado, Montana, New Mexico, North Dakota, South Dakota, Utah, and Wyoming. 
453. Gessel, G.D., 1975, Sediment storage and measurement in the Upper Colorado River Basin, proceedings, 2nd inter-agency sedimentation conference: U.S. Department of Agriculture Miscellaneous Publication 970,778 p.

454. Gifford, G.F., Humphries, William, and Jaynes, R.A., 1983, Preliminary quantification of the impacts of aspen to conifer succession on water yield within the Colorado River Basin (a process aggravating the salt pollution problem): Bureau of Reclamation Report OWRT-B-175-UTAH(1), 73 p. [Available from National Technical Information Service, Springfield, VA 22161 as NTIS Report PB-83 191 916.]

Quaking aspen cover 3.3 million hectares in the Upper Colorado River Basin, and these are gradually converting to conifer forest by the natural process of ecological succession. This change is being hastened by forest management practices that reduce fires, destroy pests, or otherwise prevent the natural processes that previously caused conifer areas to revert to the subclimax aspen. The hydrologic consequence has been forecast to cause a runoff reduction in the Colorado River as large as one million acre-feet annually, a major blow to water availability in the Lower Basin. Understanding and dealing with the problems requires quantitative comparison of the evapotranspiration rates of conifer and aspen forests under a variety of conditions for monitoring water movement in aspen (Populos tremuloides), subalpine fir (Abies lasiocarpa), and Engelmann spruce (Picea engelmannii).

455. Gilbert, R.G., Nakayama, F.S., Bucks, D.A., French, O.F., Adamson, K.C., and Johnson, R.M., 1982, Trickle irrigation; predominant bacteria in treated Colorado River water and biologically clogged emitters: Irrigation Science, v. 3, no. 2, p. 123-132.

Bacterial numbers and predominant bacterial types were determined in trickle irrigation systems receiving treated Colorado River water. Fourteen bacterial genera were isolated and identified from 86 water and sediment samples collected from trickle emitter systems receiving six water treatments. The bacteria identified were common aquatic and soil microbes and the genera in order of prevalence were Pseudomonas, Flavobacterium, Vibrio, Brevibacterium, Micrococcus, and Bacillus. A greater diversity of bacterial types was found in water that was sand filtered and received no chemical treatment. Regardless of the water treatment, Pseudomonas stutzeri was the predominant bacterium followed by Flavobacterium lutescens. The data indicated that pigmented bacteria, F. lutescens and Cytophaga hutchinsonii caused the yellow color of the slime deposits in biologically clogged emitters; and, their growth was presumably supported by $P$. stutzeri, a nonpigmented bacterium. The occurrence of Bacillus sp. was enhanced by sand and screen filtration and markedly reduced by chemical conditioning the water with either chlorine and acid or acid alone. No strictly anaerobic bacteria, such as Clostridium sp. were detected in water treated with chlorine and acid. Iron bacteria, Sphaerotilus spp., were not detected in any water or sediment samples from trickle irrigation systems.

456. Giles, T.F., 1980, Reconnaissance of ground-water resources in the vicinity of Gunnison and Crested Butte, west-central Colorado: U.S. Geological Survey Water-Resources Investigations Open-File Report 80-12, 2 sheets, scale not listed. 
457. Giles, T.F., and Brogden, R.E., 1976, Water-quality data for the Eagle River Valley in the vicinity of Eagle and Vail, west-central Colorado: U.S. Geological Survey Open-File Report 76-812, 2 sheets, scale 1:125,000.

The purpose of the investigation was to evaluate the availability and chemical quality of groundwater in the East, Taylor, and Ohio Creek basins. A review of the published geological maps and reports was made, and available data from approximately 100 existing wells were obtained. Hydraulic characteristics of the alluvial aquifers were estimated. Eighty-five water samples from wells and springs were analyzed to determine the quality of the ground water.

458. Glas, T.K., and McWhorter, D.B., 1976, Salt transport in soil profiles with application to irrigation return flows --The dissolution and transport of gypsum in soils: Fort Collins, Colo., Colorado Water Resources Research Institute Completion Report CR 71.

459. Goettl, J.P., Jr., 1969, Water pollution studies--Study of the effects of metallic ions on fish and aquatic organisms: Denver, Colo., Colorado Department of Game, Fish, and Parks, Federal Aid Project F-033-R-05, Job 6, 19 p.

460. Goettl, J.P., Jr., 1970, Water pollution studies--Study of the effects of metallic ions on fish and aquatic organisms: Denver, Colo., Colorado Department of Game, Fish, and Parks, Federal Aid Project F-033-R-06, Job 6, 80 p.

461. Goettl, J.P., Jr., 1970, Water pollution studies--Study of the effects of mineral mining and milling operations on high mountain streams: Denver, Colo., Colorado Department of Game, Fish, and Parks, Federal Aid Project F-033-R-06, Job 1, 50 p.

462. Goettl, J.P., Jr., and Davies, P.H., 1975, Water pollution studies--Study of the effects of mining and milling operations on high mountain streams: Denver, Colo., Colorado Division of Wildlife, Federal Aid Project F-33-R-10, Job 1, 5 p.

463. Goettl, J.P., Jr., and Davies, P.H., 1978, Water pollution studies--Study of the effects of mining and milling operations on high mountain streams: Fort Collins, Colo., Colorado Division of Wildlife, Federal Aid Project F-33-R-13, Job Progress Report, 1 p.

464. Goettl, J.P., Jr., and Davies, P.H., 1979, Water pollution studies--Job 1, Study of the effects of mining and milling operations on high mountain streams; Job 6, Study of the effects of metallic ions on fish and aquatic organisms: Denver, Colo., Colorado Division of Wildlife, Federal Aid Project F-33-R-14, Job Progress Report, 43 p.

465. Goettl, J.P., Jr., and Sinley, J.R., 1975, Water pollution studies--Study of the effects of metallic ions on fish and aquatic organisms: Denver, Colo., Colorado Division of Wildlife, Federal Aid Project F-33-R-5, Job Progress Report, Job 6, 39 p.

466. Goettl, J.P., Jr., Sinley, J.R., and Davies, P.H., 1971, Water pollution studies--Study of the effects of metallic ions on fish and aquatic organisms: Denver, Colo., Colorado Department of Game, Fish, and Parks, Federal Aid Project F-033-R-07, Job 6, 17 p. 
467. Goettl, J.P., Jr., Sinley, J.R., and Davies, P.H., 1972, Water pollution studies--Study of the effects of mineral mining and milling operations on high mountain streams: Denver, Colo., Colorado Division of Wildlife, Federal Aid Project F-33-R-7, Job Progress Report, Job 1, 28 p.

468. Goslin, I.V., 1976, Interstate river compacts--Impact on Colorado: Denver Journal of International Law and Policy, v. 6, p. 415-439.

469. Graf, W.L., 1984, The pattern of sediment dynamics in the Upper Colorado River Basin [abs.]: Geological Society of America Abstracts with Programs, v. 16, no. 6, p. 522.

470. Graf, W.L., 1985, The Colorado River--Instability and basin management: Washington, D.C., Association of American Geographers, $86 \mathrm{p}$.

Looks at the clash between environmental processes and human management needs in the Colorado Basin and generalizes about how societies deal with adverse environments. Considers that three major themes emerge from the spatial perspective provided; strategies based on assumed predictable averages are not useful in unstable environments; the problems created by these unstable areas are inherently spatial; and therefore a geographical perspective offering radical alternatives is required. Looks at the past evidence for human use and hydrologic instability; the nature of the riparian vegetation and its management; the processes and causes of vertical and horizontal channel instability; the creation of arroyos and floodplain management; chemical instability; the impacts of high dams; and management perspectives.

471. Graf, W.L., 1986, Cause and effect of twentieth-century erosion in the Upper Colorado River Basin [abs.]: Geological Society of America Abstracts with Programs, v. 18, no. 6, p. 619.

472. Graf, W.L., 1994, Mercury transport in stream sediments of the Colorado Plateau: Association of American Geographers Annals, v. 75, no. 4, p. 552-565.

473. Gray, S.L., 1974, Primary data on economic activity and water use in prototype oil shale development areas of Colorado: Fort Collins, Colo., Colorado Water Resources Research Institute Completion Report CR 58.

474. Gregg, D.O., Meyer, E.L., Targy, M.M., and Moulder, F.A., 1961, Public water supplies of Colorado, 1959-1960: U.S. Geological Survey, 128 p. [Also published as Colorado State University Agricultural Experiment Station Gen. Ser. 757, 128 p.]

475. Gregory, H.E., 1947, Colorado drainage basin: American Journal of Science, v. 245, no. 11, p. 694-705.

476. Grose, L.T., 1974, Summary of geology of Colorado related to geothermal energy potential, in Proceedings of a symposium on geothermal energy and Colorado: Denver, Colo., Colorado Geological Survey Bulletin 35, p. 11-29. 
477. Gunnell, R.D., 1985, Continuous salinity station monitoring in the Colorado River Basin by the Utah Bureau of Water Pollution Control, in Perspectives on nonpoint source pollution, proceedings of a national conference, Kansas City, Missouri, May 19-22, 1985: Washington, D.C., U.S. Environmental Protection Agency, p. 356-358.

The objectives of a salinity monitoring program are to characterize the Colorado River Basin waters by determining the total dissolved solids loadings entering and leaving Utah and the relative contributions from major basins. A network of nine continuous recording salinity stations collect temperature and specific conductance data. The continuous recording devices consist of Hydrolab Datasondes are programmed and standardized in Salt Lake City before they are distributed to their specific field locations. Each salinity station is visited monthly to replace the Datasondes and to collect ambient water quality information. The data from the sondes are read and edited into a computer storage file. The conductivity data, along with chemistry and flow data are then combined to determine loadings.

478. Haff, J.C., 1946, Features of geologic structure on the Blue River-South Platte transmountain diversion line (U.S.) [abs.]: Geological Society of America Bulletin, v. 57, no. 12, p. 1199.

479. Hallam, C.A., 1993, The effect of data generalization on prediction of hydrologic response: U.S. Geological Survey Open-File Report 93-354, 64 p.

480. Hampton, E.R., 1974, Preliminary evaluation of ground water in the pre-Pennsylvanian carbonate rocks, McCoy area, Colorado: U.S. Geological Survey Open-File Report, 11 p.

481. Hansen, W.R., 1965, The Black Canyon of the Gunnison--Today and yesterday: U.S. Geological Survey Bulletin 1191, 76 p.

482. Hansen, W.R., 1967, The lower Black Canyon of the Gunnison: National Parks Magazine, v. 41, no. 238 , p. $14-19$.

483. Hansen, W.R., 1971, Geologic map of the Black Canyon of the Gunnison River and vicinity, western Colorado: U.S. Geological Survey Miscellaneous Investigations Series Map I-584, 2 sheets, scale 1:31,680.

484. Hansen, W.R., 1981, Geologic and physiographic highlights of the Black Canyon of the Gunnison River and vicinity, Colorado, in Epis, R.C., and Callender, J.F., eds., Western Slope, Colorado--Western Colorado and eastern Utah, New Mexico Geological Society, thirty-second field conference, Oct. 8-10, 1981: New Mexico Geological Society Guidebook 32, p. 145-154.

485. Hansen, W.R., 1987, The Black Canyon of the Gunnison, Colorado, in Beus, S.S., ed., Centennial field guide, v. 2, Rocky Mountain Section of the Geological Society of America: Boulder, Colo., Geological Society of America, v. 2, p. 321-324.

486. Hansen, W.R., 1987, The Black Canyon of the Gunnison in depth: Tucson, Ariz., Southwest Parks and Monuments Association, $58 \mathrm{p}$.

487. Harding, B.L., Payton, E.A., and Brown, T.C., 1990, Modeling the allocation of water from the Colorado River under a warmer climate [abs.]: EOS, American Geophysical Union Transactions, v. 71, no. 20, p. 716.

68 Bibliography, Indices, and Data Sources of Water-Related Studies, Upper Colorado River Basin, Colorado and Utah, 1872-1995 
488. Harris, E.R., 1981, Colorado River enhanced snowpack test--Environmental assessment and design phase finding of no significant impact (final report): Bureau of Reclamation Report FONSI-ERC-81-1, 40 p. [Available from National Technical Information Service, Springfield, VA 22161 as NTIS Report PB-82 237 157.]

The Colorado River enhanced snowpack test environmental assessment examines a proposal to test the viability of cloud seeding in the Colorado River Basin to increase precipitation, runoff, and water yield of streamflow. The report concludes that longterm monitoring of operational cloud seeding effects will be needed to develop a reliable picture of environmental effects, and that responses of vegetation are of particular interest because of its comparative sensitivity and its key place in the food chain.

489. Harris, K.F., Rapp, J.R., and Chase, E.B., 1968, Index to water quality stations: U.S. Geological Survey Office of Water Data Coordination, Information on Water Data Catalog, $391 \mathrm{p}$.

490. Hartley, C., 1912, Placer mining in upper valley of Grand River: Min. Eng. World, v. 37, p. 851-852.

491. Hately, J.G., 1907, Copper mining on the Colorado River: Mining World, v. 26, p. 809.

492. Hawkins, J.A., and Nesler, T.P., 1991, Nonnative fishes of the Upper Colorado River Basin-An issue paper: Fort Collins, Colo., Colorado State University and Colorado Division of Wildlife, $72 \mathrm{p}$.

493. Hay, L.E., and Battaglin, W.A., 1993, Estimation of precipitation patterns in the Delaware and Gunnison River Basins, in Kelmelis, J.A., and Snow, K.M., eds., Proceedings of the U.S. Geological Survey global change research forum, Herndon, Virginia, March 18-20, 1991: U.S. Geological Survey Circular 1086, p. 88.

494. Hay, L.E., Battaglin, W.A., Parker, R.S., and Leavesley, G.H., 1993, Modeling the effects of climate change on water resources in the Gunnison River Basin, Colorado, using GIS technology, in Goodchild, M.S., Parks, B.O., and Steyaert, L.P., eds., Environmental modeling with GIS: Oxford, England, Oxford University Press, p. 173-181.

495. Hay, L.E., Branson, M.D., and Leavesley, G.H., 1992, Simulation of precipitation in the Gunnison River Basin using an orographic-precipitation model, in Herrmann, R., ed., Proceedings of the American Water Resources Association symposium on managing water resources during global change, Reno, Nevada, November 1-5, 1992: Bethesda, Md., American Water Resources Association Technical Publication Series TPS-92-4, p. 651-660.

496. Hay, L.E., and Knapp, Loey, 1993, Visualization techniques for hydrologic modeling, in Burton, J.S., comp., Proceedings of the Federal interagency workshop on hydrologic modeling demands for the 90's: U.S. Geological Survey Water-Resources Investigations Report 93-4018, p. 3.1-3.8.

497. Hayden, F.V., 1877, Ninth annual report of the United States Geological and Geographical Survey of the Territories, embracing Colorado and parts of adjacent territories, being a report of progress of the exploration for the year 1875: U.S. Geological and Geographical Survey of the Territories (Hayden) Annual Report 9, 827 p. 
498. Hayes, B.R., and Schumm, S.A., 1989, Salt storage in alluvium in the Upper Colorado River Basin [abs.]: Geological Society of America Abstracts with Programs, v. 21, no. 6, p. 187.

499. Hayes, L.D., 1982, The Colony Shale Oil Project [abs.]: American Association of Petroleum Geologists Bulletin, v. 66, no. 5, p. 580.

500. Haynes, C.M., Lytle, T.A., Wick, E.J., and Muth, R.T., 1984, Larval Colorado squaw fish Ptychocheilus lucius in the Upper Colorado River Basin, Colorado, USA, 1979-1981:

Southwestern Naturalist, v. 29, no. 1, p. 21-34.

The Colorado River drainage in Colorado was surveyed during the summer-fall of 1979-1981 for the distribution of larval Colorado squawfish ( $P$. lucius) and to relate their occurrence to the hydrological regime. Squawfish larvae were collected in the lowermost $31 \mathrm{~km}$ of the mainstem Colorado River in 1979-1981 and the lowermost $29 \mathrm{~km}$ of the Yampa River in 1980-1981. Larval squawfish were not found in collections from either the White or Gunnison rivers. Sampling effort appeared to have no effect on collection success, but collection success did appear to reflect reproductive success and/or larval survivorship. Estimates of spawning periods for the Colorado River range from as early as June 18 in 1981 to as late as Aug. 26 in 1980. In the Yampa, spawning was estimated to occur as early as June 16 in 1980 and as late as Aug. 3 in 1981. The observations and spawning period estimates support the hypothesis that reproductive success is related to both the flow and temperature regimes, but other exogenous (e.g., photoperiod, water quality, etc.) and biotic factors (e.g., competition, predation) have yet to be adequately investigated.

501. Haynes, C.M., and Muth, R.T., 1982, Identification of habitat requirements and limiting factors for Colorado squaw fish and humpback chubs: Colorado Division of Wildlife, Federal Aid Project Progress Report SE-4, 43 p.

502. Haynes, C.M., and Muth, R.T., 1984, Identification of habitat requirements and limiting factors for Colorado squawfish and humpback chubs: Colorado Division of Wildlife, Federal Aid Project Progress Report SE-3, 21 p.

503. Haynes, C.M., Muth, R.T., and Wycoff, L.C., 1982, Range extension for the redside shiner, Richardsonius balteatus (richardson), in the Upper Colorado River drainage: Southwestern Naturalist, v. 27, no. 2.

504. HDR Engineering, Inc., 1988, Phase I feasibility study for Upper Gunnison-Uncompahgre Basin; task memorandum 1, existing water uses in the Gunnison-Uncompahgre Basin [1987]; task memorandum 3, future water demands; task memorandum 5, development and calibration of basin model comparison of existing supplies with future in-basin demands; task memorandum 6, alternative plans for water development: Gunnison, Colo., HRD Engineering, Inc.

505. HDR Engineering, Inc., 1988, Phase I feasibility study for Upper Gunnison-Uncompahgre Basin; task memorandum 4, recreation and environmental enhancement opportunities; appendix F, past water quality monitoring on selected streams and reservoirs: Denver, Colo., Colorado Water Resources and Power Development Authority, 24 p. 
506. HDR Engineering, Inc., 1989, Upper Gunnison-Uncompahgre Basin; phase I feasibility study, v. I, final report; v. II, appendices: Denver, Colo., Colorado Water Resources and Power Development Authority, various pagination.

507. Headden, W.P., 1905, The Doughty Springs, a group of radium-bearing springs, Delta County, Colorado: Denver, Colo., Colorado Scientific Society Proceedings, v. 8, p. 1-30.

508. Headden, W.P., 1909, Notes on some mineral springs: Denver, Colo., Colorado Scientific Society Proceedings, v. 9, p. 259-272.

509. Hearne, G.A., Lindner-Lunsford, Jaye, Cain, Doug, Watts, K.R., Robson, S.G., Tobin, R.L., Teller, R.W., Schneider, P.A., Jr., and Gearhart, M.J., 1987, Colorado ground-water quality: U.S. Geological Survey Open-File Report 87-716, 10 p.

510. Hearne, G.A., Lindner-Lunsford, Jaye, Cain, Doug, Watts, K.R., Robson, S.G., Tobin, R.L., Teller, R.W., Schneider, P.A., Jr., and Gearhart, M.J., 1988, Colorado ground-water quality, in Moody, D.W., Carr, J.C., Chase, E.B., and Paulson, R.W., comps., National water summary 1986--Hydrologic events and ground-water quality: U.S. Geological Survey Water-Supply Paper 2325, p., 181-190.

511. Heaton, R.L., 1940, Geological aspects of the Colorado-Big Thompson Project: Mines Magazine, v. 30 , no. 5 , p. $257-264$.

512. Heaton, R.L., 1946, Engineering geology of Alva B. Adams Tunnel, Colorado-Big Thompson Project, Colorado [abs.]: Geological Society of America Bulletin, v. 57, no. 12, pt. 2, p. 1200-1201.

513. Hedlund, H.D., 1984, USDA planning process for Colorado River Basin salinity control, in French, R.H., ed., Salinity in watercourses and reservoirs, proceedings of the 1983 international symposium on state-of-the-art control of salinity, Salt Lake City, Utah, July 13-15, 1983: Stoneham, Mass., Butterworth Publishers, p. 63-77.

514. Heermann, D.F., 1967, Climatological and phenological patterns in Western U.S., progress report to regional research technical committee: Fort Collins, Colo., Colorado State University. [Annual report, also published in years 1964-1966.]

515. Heermann, D.F., 1967, Colorado precipitation patterns, in Gifford, R.O., ed., Probability of selected precipitation amounts in the western region of the United States: Nevada Agr. Exp. Sta. Bull. T8.

516. Heim, W.P., and Miller, C., 1983, Water use and reuse opportunities and costs at oil shale plants, v. 2: Bureau of Reclamation Report OWR/RU-83/11, 325 p. [Available from National Technical Information Service, Springfield, VA 22161 as NTIS Report PB-85 128 718/XAB.]

Mining and processing of oil shale into fuels will consume large amounts of water and will vary from plant to plant. Variations in types of resources and the products produced will lead to a variety of mining and processing schemes each with their own water use patterns. This report describes several of these schemes, as well as their water use and waste water production patterns, water treatment plant designs, water costs, and opportunities for internal water reuse and recycling. This diversity leads to many waste water streams and a variety of opportunities for using low grade 
waters. This project analyzed the ways that water will be used, and may be reused, in oil shale plants located in the Upper Colorado River Basin.

517. Hendricks, D.W., and Ward, J.C., 1976, Environmental analysis of an oil-shale industry in the Upper Colorado region, in Yen, T.F., and Chilingarian, G.V., eds., Oil shale: Amsterdam, The Netherlands, Elsevier, p. 215-234.

518. Hennig, R.A., and Olson, J.B., 1976, The Colorado River salinity problems, old approaches to a new issue: Land and Water Law Review, v. 11, no. 2, p. 459-480.

The Colorado River has a high salinity level which increases as the river flows south to the Gulf of California. Salt loading occurs when additional solids are added to the river while salt concentrating results when water is removed. The economic problems created by the high salinity are described. A brief survey of present and planned salinity control programs on the Colorado is described with a view to identifying whether or not past patterns of policy making and problem allocation of the river are being carried over in to the attempted management of the salinity problem. Details are given of interim and permanent international salinity agreements, salinity control above Imperial Dam and salinity and federalization of the river.

519. Herron, W.H., 1917, Profile surveys in the Colorado River Basin in Wyoming, Utah, Colorado, and New Mexico: U.S. Geological Survey Water-Supply Paper 396, 6 p.

520. Hess, M.E., 1984, Case study of a major agricultural control program--The Grand Valley experience, in French, R.H., ed., Salinity in watercourses and reservoirs, proceedings of the 1983 international symposium on state-of-the-art control of salinity, Salt Lake City, Utah, July 13-15, 1983: Stoneham, Mass., Butterworth Publishers, p. 285-294.

521. Hibbert, A.R., 1979, Managing vegetation to increase flow in the Colorado River Basin: U.S. Department of Agriculture, Forest Service Rocky Mountain Forest and Range Experiment Station General Technical Report RM-66, 34 p. [Available from National Technical Information Service, Springfield, VA 22161 as NTIS Report PB-80 125 859.]

Water yield from forest and rangelands can be augmented by managing vegetation and snow to reduce evapotranspiration. Some arbitrary goals to increase water yield were chosen to illustrate the potential for increasing water yield, and treatments were hypothesized to get these increases.

522. Hickman, D., 1986, Water quality trends for Blue Mesa Reservoir, Gunnison, Colorado-A baseline water quality survey conducted by the National Park Service, 1982-1985: Gunnison, Colo., Western State College, Master's thesis.

523. Hickman, T.J., 1983, Effects of habitat alteration by energy resource developments in the Upper Colorado River Basin on endangered fishes, in Adams, V.D., and Lamarra, V.A., eds., Aquatic resources management of the Colorado River ecosystem, proceedings of the 1981 symposium, Las Vegas, Nevada, November 16-18, 1981: Ann Arbor, Mich., Ann Arbor Science Publishers, p. 537-550. 
524. Hills, R.C., 1887, Circulation of water through the strata of the upper Cretaceous coal measure of Gunnison County, Colorado: Denver, Colo., Colorado Scientific Society Proceedings 2, p. 127-133.

525. Hinderlider, M.C., and Swendsen, G.L., 1906, Report of progress of stream measurements for the calendar year 1905, part XI, Colorado River drainage above Yuma: U.S. Geological Survey Water-Supply Paper 175, 194 p.

526. Hodgden, H.J., 1960, The geology around the junction of the Roaring Fork and Frying Pan Rivers, Eagle and Pitkin Counties, Colorado: Lawrence, Kans., University of Kansas, Master's thesis.

527. Holburt, M.B., 1982, Colorado River water allocation, in Water and energy development in an arid environment--The Colorado River Basin: Water Supply and Management, v. 6, no. 1-2, p. 63-73.

528. Holburt, M.B., 1984, The 1983 high flows on the Colorado River and their aftermath: Water International, v. 9, no. 3, p. 99.

529. Holburt, M.B., and Crawford, A.B., 1978, International problems, in Peterson, D.F., and Crawford, A.B., eds., Values and choices in the development of the Colorado River Basin: Tucson, Ariz., University of Arizona Press, p. 220-237.

In August, 1973, the United States and Mexico executed the latest in a series of agreements that have attempted to settle the international problems of the Colorado River. In January, 1974, representatives from the seven Colorado River Basin states introduced H.R. 12165, 'The Colorado River Basin Salinity Control Act', to the House of Representatives. This bill would authorize those measures considered necessary by the basin states to implement the latest agreement and also authorize a major basinwide Colorado River Basin Salinity Control Program. Also in January, the administration sent legislation to Congress which contains the measures it considers necessary to implement the 1973 agreement. Major differences between the bill submitted by the basin states and the bill submitted by the administration resulted in continuing controversy. This chapter discusses the Colorado River water quality and quantity problems between the United States and Mexico, considerations that have led to the several agreements between the two countries and possible future actions.

530. Holburt, M.B., and Valentine, V.E., 1972, Present and future salinity of Colorado River: American Society of Civil Engineers, Journal of the Hydraulic Division, v. 98, no. HY3, p. 503-520.

531. Holden, P.B., 1977, Habitat requirements of juvenile Colorado River squawfish: U.S. Fish and Wildlife Service Report FWS/OBS-77/65, 70 p.

532. Holden, P.B., and Stalnaker, C.B., 1975, Distribution and abundance of mainstream fishes of the middle and Upper Colorado River Basins, 1967-1973: American Fisheries Society Transactions, v. 104, p. 217-231.

533. Holland, W.T., and Jarvis, C.S., 1938, Inventory of unpublished hydrologic data: U.S. Geological Survey Water-Supply Paper 837, 77 p. 
534. Holmes, W.H., 1890, Formation of Gunnison and Grand Rivers: Geological Society of America Bulletin, v. 1, p. 274.

535. Holt, H.E., 1961, Geology of the lower Blue River area, Summit and Grand Counties, Colorado: Boulder, Colo., University of Colorado, Ph.D. dissertation, $107 \mathrm{p}$.

536. Hoover, R.L., 1974, Guidelines for identification, designation and administration of significant wildlife habitats and shorelands of major publically owned reservoirs: Denver, Colo., Colorado Division of Wildlife, $20 \mathrm{p}$.

537. Hopkins, J.K., 1975, Water quality management planning for the Roaring Fork River Basin in western Colorado: Los Angeles, Calif., University of California, Ph.D. dissertation, $254 \mathrm{p}$.

538. Hopper, R.M., 1968, Wetlands of Colorado: Denver, Colo., Colorado Division of Wildlife Technical Publication 22, $89 \mathrm{p}$.

539. Horn, B., 1990, Interim report on the biological assessment of the Eagle River Superfund Site, Eagle County, Colorado: Colorado Division of Wildlife, $20 \mathrm{p}$.

540. Horn, B., and Woodling, J., 1991, Final report, biological monitoring assessment, Eagle River Superfund Site, Eagle County, Colorado (for 1990 sampling, April and September): Colorado Division of Wildlife, $23 \mathrm{p}$.

541. Horn, T.G., 1877, Report on the mineral springs of Colorado, in Colorado State Board of Health, annual report: Colorado State Board of Health, p. 43.

542. Hornberger, G.M., Bencala, K.E., and McKnight, D.M., 1994, Hydrological controls on dissolved organic carbon during snowmelt in the Snake River near Montezuma, Colorado: Biogeochemistry, v. 25, no. 3, p. 147-165.

543. Hotchkiss, R.H., Israelsen, E.K., and Riley, J.P., 1980, Management of the hydrologic system in areas subject to coal mining activities: Bureau of Reclamation Report OWRT-A-046-UTAH(1), 93 p. [Available from National Technical Information Service, Springfield, VA 22161 as NTIS Report PB-81 127 383.]

The report examines the effects of present mining activities on the associated hydrologic system and identifies specific mining procedures and management techniques which not only minimize negative hydrologic impacts of mining operations but which also enhance the value of the hydrologic system in terms of existing and potential social uses. Thus, the results of the research contribute to the solution of present and future hydrologic problems (both quantity and quality) associated with coal mining in the western U.S. Emphasis is placed on sites which are representative of both existing and future coal mining areas. The study suggests not only ways of reducing negative hydrologic impacts of mining operations but also operational and management mining techniques which will enhance the social use value of the hydrologic systems, and thus, in fact, create hydrologic opportunities.

544. Hotes, F.L., and Pearson, E.A., 1977, Effects of irrigation on water quality, in Worthington, E.B., ed., Arid land irrigation in developing countries--Environmental problems and effects: Oxford, England, Pergamon Press, p. 127-158. 
545. Houk, R., 1991, Black Canyon of the Gunnison: Tucson, Ariz., Southwest Parks and Monuments Association, $14 \mathrm{p}$.

546. Howard, C.S., 1928, Suspended matter in the Colorado River and its relation to the development of the river: Washington, D.C., American University, Ph.D. dissertation.

547. Howard, C.S., 1930, Suspended matter in the Colorado River in 1925-28, chap. B. of Contributions to the hydrology of the United States, 1929: U.S. Geological Survey WaterSupply Paper 636, p 15-44.

548. Howard, C.S., 1932, Quality of water of the Colorado River in 1928-30, chap. D of Contributions to the hydrology of the United States, 1931: U.S. Geological Survey Water-Supply Paper 638, p. 145-162. [Also available is Quality of water of the Colorado River in 1926-1928, chap. A of Contributions to the hydrology of the United States, 1929, published in 1930 as Water-Supply Paper 636, p. 1-14.]

549. Howard, C.S., 1947, Suspended sediment in the Colorado River, 1925-41: U.S. Geological Survey Water-Supply Paper 998, $165 \mathrm{p}$.

550. Howard, C.S., 1955, Quality of water of the Colorado River, 1925-1940: U.S. Geological Survey Open-File Report, 103 p.

551. Howard, C.S., and Love, S.K., 1945, Quality of surface waters of the United States, 1943, with a summary of analyses of streams in Colorado River, Pecos River, and Rio Grande Basins, 1925 to 1943: U.S. Geological Survey Water-Supply Paper 970, 180 p.

552. Howe, C.W., 1987, Project benefits and costs from national and regional viewpoints-Methodological issues and case study of the Colorado-Big Thompson Project: Natural Resources Journal, v. 27, no. 1, p. 5-20.

553. Howe, C.W., and Ahrens, W.A., 1988, Water resources of the Upper Colorado River Basin-Problems and policy alternatives, in El-Ashry, M.T., and Gibbons, D.C., eds., Water and arid lands of the Western U.S.: Cambridge, England, Cambridge University Press, p. 169-232.

The Colorado River is the major surface water resource of the Southwest. In spite of John Wesley Powell's forecast that the region would never be useful or inhabited, the river basin has been fought over and romanticized more than any western river. The influence of the financial power and the concentration of political power on water issues have dominated the policy scene, and since passage of the Reclamation Act of 1902, the federal government through the Bureau of Reclamation has been the agent of project construction and water supply provision. It is a major contention of this study that the Upper Basin is not and will not be short of water if the states of the basin use their supplies in an economically reasonable way. Changing values call for greater protection of instream flows, and the high costs of developing new supplies for municipal and industrial uses indicate the desirability of transferring water from agriculture to urban areas. Only extreme shortsighted ness and a thoughtless scramble to put all their water to use quickly could lead to a future water crisis. 
554. Howe, C.W., Kreider, J.F., and Udis, Bernard, 1972, An economic analysis of the pollution problems in the Colorado River Basin--The Upper Main Stem sub-basin (interim research report): Boulder, Colo., University of Colorado Report EDA/OER-74-308, 257 p.

[Available from National Technical Information Service, Springfield, VA 22161 as NTIS Report COM-74-11311/9.]

The purpose of the study is to develop a set of compatible models relating the economic activities of the sub-basins of the Colorado River, both present and prospective, to air quality and water quantity and quality resulting from these patterns of economic activity. This model will permit the planner to test some of the environmental implications of alternative growth patterns for the region. The study describes in detail the models which have been developed and calibrated for the Upper Main Stem sub-basin, an area which contains the origins of the most pressing problems of the Basin: salinity, shale oil industry future impacts, and expanded diversions to the Rocky Mountain Eastern slope.

555. Howe, C.W., and Murphy, A.H., 1981, The utilization and impacts of climate information on the development and operations of the Colorado River system, appendix C: Rockville, Md., National Oceanic and Atmospheric Administration, 9 p. [Available from National Technical Information Service, Springfield, VA 22161 as NTIS Report PB-82 171 265.]

556. Howe, C.W., and Orr, D.V., 1974, Economic incentives for salinity reduction and water conservation in the Colorado River Basin, in Flack, J.E., and Howe, C.W., eds., Salinity in water resources, proceedings of the 15th annual Western Resources Conference, July 1973, University of Colorado: Boulder, Colo., Merriman, p. 120-138.

557. Howe, C.W., and Orr, D.V., 1974, Effects of agricultural acreage reduction on water availability and salinity in the Upper Colorado River Basin: Water Resources Research, v. 10, no. 5, p. 893-897.

558. Howe, C.W., Schurmeier, D.R., and Shaw, W.D., 1986, Innovations in water management-Lessons from the Colorado-Big Thompson Project and Northern Colorado Water Conservancy District, in Scarce water and institutional change: Washington, D.C., Resources for the Future, p. 171-200.

The Colorado-Big Thompson Project (C-BT) that transfers water from the western slopes of the Rocky Mountains to northeastern Colorado both required and inspired institutional innovation. The C-BT had to guarantee the repayment of project costs as required by the Bureau of Reclamation laws, negotiate solutions to conflicts with the basin of origin, and allocate water among users with varied water needs. These challenges led to the establishment in 1937 of the Northern Colorado Water Conservancy District (NCWCD). Much credit for the success of the C-BT must be given to the unusual system of water markets that evolved within the district and the set of legal and administrative conditions that made these markets possible. The major methods for allocating large water supplies within the market system are priority allocation rules and proportional rules. Under a priority rule, the various users are assigned certain quantities of water per time period, and each of these quantities has a priority number. A proportional rule divides available water among a group of users according to a fixed set of proportions. The total amount of C-BT water available to the district each year is determined by the quota system. In the 
C-BT-NCWCD system, return flows are owned by the district. When a buyer and a seller wish to effect an allotment transfer, they submit an application to the district. Transfers can sometimes be facilitated by brokers of NCWCD allotments. Rentals (transfers of water among users for one season only) occur not only with NCWCD water but also with appropriated and ditch company water. The water markets used by the NCWCD are more efficient than methods currently used by Federal and State water agencies and might be copied for many places in the West and elsewhere.

559. Howe, C.W., and Young, J.T., 1981, The measurement of regional economic effects of changes in irrigation water salinity within a river basin framework; the case of the Colorado River ( USA), in Yaron, D., ed., Salinity in irrigation and water resources: New York, N.Y., M. Dekker, p. 215-244.

This salinity management study of the Colorado River watershed uses existing regional economic models to evaluate water quantity and quality trade-offs between the Upper and Lower Basins. A cost schedule for salt load reduction is derived for the upstream area, which contributes most of the salt, and a schedule of marginal benefits accruing from reduced salinity is derived for downstream water users. The study concentrates on agricultural water use since agriculture is responsible for about 90 percent of consumptive water use and contributes about 37 percent of the river's salinity concentration. Crop yield responses to changing salinity conditions are examined, and a model of the regional income-generating mechanisms, which evaluates the economic impacts of salinity-reduced crop output, is discussed. The effects of agricultural acreage reduction, a major step that could reduce salinity and increase water availability in the Lower Basin, are considered. Finally, downstream benefits and upstream costs are viewed concurrently, allowing the selection of economically efficient steps for mitigating the salinity problems of the Colorado River Basin.

560. Hsiao, J.S., Sheikh-ol-Eslami, Bahman, and Botham, L.S., 1979, Ammonia investigations in the Colorado River; Grand Junction and Fruita, Colorado (final report): U.S. Environmental Protection Agency Report EPA-908/5-79-004, 215 p. [Available from National Technical Information Service, Springfield, VA 22161 as NTIS Report PB-80 130 180.]

Near the western border of Colorado, the Colorado River is the habitat of four threatened and endangered fish species as well as the receiving water course for sewage effluent from the cities of Grand Junction and Fruita. An extensive monitoring program was conducted to sample four water quality parameters which affect the concentration of un-ionized ammonia, a substance toxic to fishes at high concentrations. Temperature, $\mathrm{pH}$, total ammonia, and flow were measured for thirteen months along a $20 \mathrm{~km}$ reach of the river. Collected data and historical data were compared and analyzed to establish representative background conditions on a monthly basis. These conditions were then used to determine the monthly total ammonia loading allocations for the proposed wastewater treatment facilities at each of the two cities that would maintain a safe level of un-ionized ammonia in the river. 
561. Hughes, T.C., and Orlovsky, S., 1984, Salt gradient ponds; investment timing model: Journal of Water Resources Planning and Management, v. 110, no. 4, p. 403-417.

Salt gradient solar ponds can play an important role in management of river salinity in semiarid locations such as the Colorado River Basin. A mathematical model and solution procedure are presented for investment timing of expansion of a salt gradient pond system. An application of the model is presented for several sites in the Upper Colorado River Basin where planned fossil fuel electric generating plants are located near existing source of saline or brackish water. The concept involves use of both concentrated brine waste streams from the power plants and the existing low quality water sources for the pond system water and salt demands. The salt gradient pond can replace a power plant's customary zero discharge evaporation, produce additional energy, and remove much more salt from the river system than the conventional evaporation pond. An economic model solution procedure and application are presented for expansion of salt gradient pond systems. Such systems have important potential for salinity management applications, when used in conjunction with thermal/electric plants near sources of saline water.

562. Hundley, N., 1975, Water and the West--The Colorado River Compact and the politics of water in the American West: Berkeley, Calif., University of California Press, 416 p.

563. Hunt, C.B., 1969, Geologic history of the Colorado River, chap. C of The Colorado River region and John Wesley Powell: U.S. Geological Survey Professional Paper 669, p. 59-130.

The geologic history of each stretch of the Colorado River and its principal tributaries from their headwaters to the Gulf of California is reviewed. Neither antecedence nor superposition alone seems adequate to account for the anomalous canyons across the many structural barriers, but a combination of the processes (anteposition) resolves most seeming conflicts in the evidence. This concept of duality assumes a river course superimposed across a barrier and its canyon subsequently deepened by antecedence because of later uplift of the barrier. Stratigraphic evidence at several uplifts indicates this history; the Grand Canyon was eroded before middle Miocene time. The ancestral drainage probably discharged westward at Peach Springs; it had reached the delta before the end of Miocenc time.

564. Hunter, J.F., 1925, Pre-Cambrian rocks of Gunnison River, Colorado: U.S. Geological Survey Bulletin 777, $94 \mathrm{p}$.

565. Hurr, R.T., and Hearne, G.A., 1985, Colorado--Ground-water resources, in U.S. Geological Survey, National water summary 1984--Hydrologic events, selected water-quality trends, and ground-water resources: U.S. Geological Survey Water-Supply Paper 2275, p. 153-160.

566. Hurr, R.T., and Richards, D.B., 1974, Hydrologic investigations, chap. E of Robinson, C.S., Fitzhugh, T.L., and others, Engineering geologic, geophysical, hydrologic, and rock-mechanics investigations of the Straight Creek Tunnel site and pilot bore, Colorado: U.S. Geological Survey Professional Paper 815, p. 79-92.

567. Hurr, R.T., Wilson, W.W., Welder, F.A., and Emerson, R.L., 1969, Records of selected wells and springs in the Rulison Project area, Garfield and Mesa Counties, Colorado: U.S. Geological Survey Open-File Report, 17 p. 
568. Hutchins, W.A., Ellis, H.H., and DeBraal, J.P., 1971, Water rights laws in the nineteen western states, v. 1: U.S. Department of Agriculture Economic Research Service Miscellaneous Publication 1206, $680 \mathrm{p}$.

569. Hyatt, M.L., Riley, J.P., McKee, M.L., and Israelsen, E.K., 1970, Computer simulation of the hydrologic-salinity flow system within the Upper Colorado River Basin: Logan, Utah, Utah Water Research Laboratory Report EPA-WQO-16090-DVU-07/70, 263 p. [Available from National Technical Information Service, Springfield, VA 22161 as NTIS Report PB-203 674.]

Changes in the hydrologic equilibrium of a river basin resulting from resource development also produce changes in the quality pattern. Since the burden of quality maintenance must be shared by users (just as are quantities) predictions are needed for quality changes which might result from contemplated development at any specified location within the river system. This study reports the development of a computer simulation model of the water and salt flow systems within the Upper Colorado River Basin. Because of the close relationship between the hydrologic and salinity flow systems, an understanding of the hydrologic system is essential to successful management of the salinity system. In this study, development of a hydrologic model is based on water budgeting or accounting procedures, in which available data on historical water flows, municipal and industrial uses, and the demands of agriculture are used. The salinity dimension is then added, and the joint hydro-salinity model is verified (calibrated and tested) by comparing computed and observed output values. The utility of the model is demonstrated by applying it to a particular subbasin of the San Juan River and predicting the effects on down stream water quantity and quality of developing a large irrigation project within the area.

570. Hynes, J.L., 1983, Geology of the Glenwood Canyon along I-70, in Hynes, J.L., ed., Proceedings of the 33rd annual highway geology symposium--Engineering geology and environmental constraints, Vail, Colo., Sept. 15-17, 1982: Denver, Colo., Colorado Geological Survey Special Publication 22, p. 136-146.

571. Ince, S., 1986, The Colorado River, instability and basin management; book review: Journal of Hydrology, v. 85, no. 1-2, p. 203-204.

572. Inman, R.R., Olson, D.C., and King, D.L., 1984, Grand Valley salt pick-up calculations, in French, R.H., ed., Salinity in watercourses and reservoirs, proceedings of the 1983 international symposium on state-of-the-art control of salinity, Salt Lake City, Utah, July 13-15, 1983: Stoneham, Mass., Butterworth Publishers, p. 157-167.

573. Iorns, W.V., Hembree, C.H., and Oakland, G.L., 1965, Water resources of the Upper Colorado River Basin --Technical report: U.S. Geological Survey Professional Paper 441, 370 p.

574. Iorns, W.V., Hembree, C.H., Phoenix, D.A., and Oakland, G.L., 1964, Water resources of the Upper Colorado River Basin--Basic data: U.S. Geological Survey Professional Paper 442, 1036 p.

This basic data section of a report on the water resources of the Upper Colorado River Basin contains tables of duration of water discharge at 176 stream-gaging sites, summaries of chemical quality and sediment analyses for surface waters, and chemical quality and other characteristics of ground water, and isohyetal maps of precipitation. Also included is an inventory of surface-water records of streamflow, chemical 
quality, and suspended sediment. The isohyetal maps and maps of locations of gaging stations, sample sites, and wells and springs are given in a separate pocket.

575. Irrigation Journal, 1991, Grand Valley on-farm programs protect Colorado River from salt: Irrigation Journal, v. 41, no. 6, p. 8.

576. Isaacson, M.S., 1986, Aggregate water resources for large-scale energy development in the Upper Colorado River Basin: Energy, v. 11, no. 3, p. 281-292.

This paper addresses the question of whether or not a large (significant in national terms) energy recovery industry can be developed in the Upper Colorado River Basin (UCRB), alongside more traditional water use, without causing a problem in the aggregate quantity of water supplied to the Lower Colorado River Basin. On the demand side, aggregate water consumption in the UCRB due to water-intensive energy industry is predicted as a function of the level of energy production. Total UCRB water consumption can then be found by adding to the energy-related water use all nonenergy-related consumption. On the supply side, aggregate water availability is determined from the results of a steady-state, stochastic hydrologic model which predicts the reliability of flow to the Lower Basin as a function of total UCRB consumption.

577. Isaacson, M.S., and Fall, T.C., 1979, Conference on western water issues held at the California Institute of Technology, Pasadena, California, May 17-18, 1979: U.S. Department of Energy Report CONF-7905141-, 190 p. [Available from National Technical Information Service, Springfield, VA 22161 as NTIS Report EQL-Memo-22.]

Over the last few years several potential conflicts have emerged over the manner in which water is put to beneficial use in the western United States. These potential problems have been further heightened by the western drought of 1976-1977 and by the recent upsurge of interest in developing western coal and oil-shale resources. The conference on Western Water Issues, held at the California Institute of Technology, 17-18 May, 1979, provided a forum for representatives of industry, agriculture, government, environmental groups, research establishments and universities to exchange ideas on the subject. Most of the discussions centered on California and the Colorado River Basin. Specific items discussed included climatic fluctuations and predictability of the basic water supply; existing water law and needed changes; economics of water and the lack of real water markets, pending California state legislation (on the Peripheral Canal in the Sacramento-San Joaquin Delta area and on the limits to pumping overd rafted ground water basins); water availability for energy resources development; and competing needs by municipalities, industry, and agriculture. As a summary of the conference, this report should be regarded as a source book to clarify the issues and direct the reader to relevant individuals and references. 
578. Jackson, W.L., Bentley, R.G., and Fisher, S., 1984, Salinity status report, 19801982--Results of Bureau of Land Management studies on public lands in the Upper Colorado River Basin (technical note): Bureau of Land Management Report YA/PT-84/008/4340, 62 p. [Available from National Technical Information Service, Springfield, VA 22161 as NTIS Report PB-85 $147270 / X A B$.

In 1975, the Bureau of Land Management established a team to study salt runoff from public lands in the Colorado River Basin. The emphasis of the program shifted in 1983 from studies to the identification of opportunities to reduce salinity through watershed treatments and other land management activities. The BLM has issued two Salinity status reports (USDI, 1978; USDI, 1980). The first (1977 status report) described the salinity problem and provided a thorough review of salinity literature, including quantitative and qualitative descriptions of salt pickup and transport mechanisms occurring on public lands. The second (1978-79 status report) reviewed three specific point-source salinity control projects.

579. Jacobs Engineering Group, Inc., 1994, Baseline risk assessment of groundwater contamination at the uranium mill tailings site at Grand Junction, Colorado: U.S. Department of Energy Report DOE/AL/62350-104 REV. 1, various pagination.

580. Jacobs Engineering Group, Inc., 1994, Baseline risk assessment of groundwater contamination at the uranium mill tailings site near Gunnison, Colorado: U.S. Department of Energy Report DOE/AL/62350-57D REV. 1, various pagination.

581. Jacobs Engineering Group, Inc., 1994, UMTRA Project water sampling and analysis plan-Grand Junction, Colorado: U.S. Department of Energy Report DOE/AL/62350-133 REV. 0, various pagination.

582. Jacobs Engineering Group, Inc., 1994, UMTRA Project water sampling and analysis plan-Gunnison, Colorado: U.S. Department of Energy Report DOE/AL/62350-132 REV. 1, various pagination.

583. Jacobs Engineering Group, Inc., 1994, UMTRA Project water sampling and analysis plan-Old and New Rifle, Colorado: U.S. Department of Energy Report DOE/AL/62350-141 REV. 0, various pagination.

584. Jacobsen, B., 1983, Colorado River management to enhance aquatic resources, in Adams, V.D., and Lamarra, V.A., eds., Aquatic resources management of the Colorado River ecosystem, proceedings of the 1981 symposium, Las Vegas, Nevada, November 16-18, 1981: Ann Arbor. Mich., Ann Arbor Science Publishers, p. 13-16.

585. Jacoby, G.C., Jr., Simpson, H.J., Mathieu, G., and Torgersen, T., 1979, Analysis of groundwater and surface water supply interrelationships in the Upper Colorado River Basin using natural radon-222 as a tracer: Napa, Calif., John Muir Institute, 46 p.

586. Jacoby, G.C., Jr., and Weatherford, G.D., 1975, Impact of energy development on the law of the Colorado River: Natural Resources Journal, v. 15, no. 1, p. 171-213. 
587. Jacoby, G.C., Jr., and Weatherford, G.D., 1975, Long-term surface water supply in the Colorado River Basin and its relationship to depletion curves and the law of the river [abs.]: Geological Society of America Abstracts with Programs, v. 7, no. 7, p. 1132.

588. Jamail, M.H., McCain, J.R., and Ullery, S.J., 1978, Federal-state water use relations in the American West--An evolutionary guide to future equilibrium (information paper): Bureau of Reclamation Report OWRT-W-245(7819)(1), 164 p. [Available from National Technical Information Service, Springfield, VA 22161 as NTIS Report PB-286 309/0.]

Federal-state relations in the field of water resources development in the Colorado River Basin are examined through a review of the literature. A framework is set out in which water policy development in the states of the Colorado River Basin (Arizona, Colorado, Wyoming, California, Nevada, Utah, and New Mexico) can be explained. Distributive, redistributive, and regulatory politics are defined as the three arenas in which water policy discussions take place. After this model is explained, development of water projects and policies in the Basin is explored. The 1977 Carter administration's proposal to take water politics out of the distributive arena is examined, and the authors conclude that the administration yielded on most of its proposed reforms to avoid a repetition of the 1977 confrontation with the Congress.

589. James, L.D., 1983, Integrating aquatic resource values into Colorado River management, in Adams, V.D., and Lamarra, V.A., eds., Aquatic resources management of the Colorado River ecosystem, proceedings of the 1981 symposium, Las Vegas, Nevada, November 16-18, 1981: Ann Arbor, Mich., Ann Arbor Science Publishers, p. 659-665.

590. Jarrett, R.D., 1987, Flood hydrology of foothill and mountain streams in Colorado: Fort Collins, Colo., Colorado State University, Ph.D. dissertation, 239 p.

591. Jensen, A.R., 1976, Computer simulation of surface water hydrology and salinity with an application to studies of Colorado River management: Pasadena, Calif., California Institute of Technology Environmental Quality Laboratory Report 12.

Management of a large river basin requires information regarding the interactions of variables describing the system. A method has been developed to determine these interactions so that the resources management within a given river basin can proceed in an optimal way. The method can be used as a planning tool to display how different management alternatives affect the behavior of the river system. Direct application is made to the Colorado River Basin. A computer simulation model has been developed and used to simulate the effects of various management alternatives upon water conservation, water quality, and power production. Reservoir evaporation, discharge, discharge salinity, and power generating capacity are examined.

592. Jobin, D.A., 1953, Ground-water studies [Colorado Plateau], in Geologic investigations of radioactive deposits, semiannual progress report, June 1 to November 30, 1953: U.S. Geological Survey Trace Element Investigations Report 390, p. 35-36.

593. Johncox, D.A., 1993, Silver concentrations and selected hydrologic data in the Upper Colorado River Basin, 1991-92: U.S. Geological Survey Open-File Report 93-447, 13 p. 
594. Johnson, B., 1994, Ecological effects of reservoir operations on Blue Mesa Reservoir, annual progress report, June 1, 1993 - May 31, 1994: Fort Collins, Colo., Colorado State University.

595. Johnson, J.H., 1925, Bibliography of Colorado maps published by the State and Federal governments: Colorado School of Mines Quarterly, v. 20, no. 3.

596. Johnson, J.H., 1926, Bibliography of the geology and related subjects of northwestern Colorado--Revised to June 1, 1926: Colorado School of Mines Quarterly, v. 21, no. 3, 52 p.

597. Johnson, J.H., 1927, Bibliography of the geology of north-central Colorado: Colorado School of Mines Quarterly, v. 22, no. 4, 38 p.

598. Johnson, K.L., 1965, An analysis of State regulations of surface-ground water development and use in Colorado: Fort Collins, Colo., Colorado State University, Ph.D. dissertation, 118 p.

599. Johnson, K.R., 1939, Plant ecology of northwestern Colorado lakes and surrounding areas: Boulder, Colo., University of Colorado, Ph.D. dissertation, 134 p.

600. Johnson, K.R., 1941, Vegetation of some mountain lakes and shores in northwestern Colorado: Ecology, v. 22, no. 3, p. 306-316.

601. Johnson, R.K., and Schumm, S.A., 1982, Geomorphic and lithologic controls of diffuse-source salinity, Grand Valley, western Colorado (completion report): Bureau of Reclamation Report OWRT-B-203-COLO(1), 99 p. [Available from National Technical Information Service, Springfield, VA 22161 as NTIS Report PB-82 256 587. Also published through Colorado State University, Fort Collins, as Colorado Water Resources Research Institute Completion Report CR 110.]

Grand Valley Mancos Shale, composed of a thick sequence of interbedded shale and sandstone, is a significant contributor of dissolved solids to the Upper Colorado River. Research was carried out to describe the area geomorphology and soluble mineral content relationships of surficial materials in erosionally-unstable landforms, to relate geomorphic stability to salt release processes from the area, and to recommend land use and/or salt control measures for reducing salt load to the river. Three landforms exist in the area studies: pediments, alluvial valley floors, and badlands, with the latter having the greatest surface area. The badlands are the least stable landform, releasing more sediment and salt into runoff than the other landforms. Pediments are capped by cemented gravels and are the most stable landform, while the alluvial valley floors are generally also stable to sediment/salt production. Recommendations for understanding erosional and salinity characteristics of runoff from the badlands and for reducing erosion/salinity related to current land use included examining the effectiveness of existing sediment retention structures, comparing sediment load and salinity of runoff from the two drainage basin lithologies, and reducing gully erosion caused by road drainage ditches/culverts. 
602. Johnson, R.W., 1975, Legal and institutional problems in the management of salinity (project completion report, March 18-June 30, 1975): Bureau of Reclamation Report OWRT-A-076WASH(1), 47 p. [Available from National Technical Information Service, Springfield, VA 22161 as NTIS Report PB-244 730/8.]

The study examines the Colorado River Basin salinity management program. The optimal solution will generally be found by considering the problem on a basinwide basis. In most cases the optimal solution is one that would result in the least total cost per unit for the largest salinity reduction. This optimal solution requires extensive voluntary cooperation among all water users: it has proven quite effective in the Colorado River Basin. The recommendations for a comprehensive basinwide or regional management entity to plan and implement a salinity control program for the Colorado Basin have, to date, produced a voluntary, cooperative interstate discussion group, the 'Colorado River Basin Salinity Control Forum'. To date all irrigation efficiency and water use management programs have been voluntary and are based on education and persuasion rather than on legal regulation. Most water managers and other experts in the Colorado River Basin believe the voluntary program will, in the long run, be more effective.

603. Johnson, R.W., 1978, Our salty rivers; legal and institutional approaches to salinity management: Land and Water Law Review, v. 13, no. 2, p. 441-464.

No water law system developed in the U.S. to date adequately addresses salinity management. Legal and institutional approaches to pollution control that work elsewhere are considerably less effective in controlling nonpoint salinity sources. The Colorado River Compact, the Boulder Canyon Project Act, the Supreme Court decision in Arizona vs. California, and the 1968 Colorado River Basin Project Act all combine to apportion supplies among the Lower Basin states. The U.S. is bound by treaty to deliver to Mexico water of acceptable saline quality. A 1971 EPA study recommended the prompt setting of numerical salinity limits, the creation of a single institutional entity with basinwide jurisdiction, legislative authorization and funding of salinity control projects, a systems analysis to evaluate quality and economic aspects of the problem and alternative solutions, and additional research on control technology. Salinity control for the benefit of Mexico is a national, not regional, responsibility and fiscal obligation. Salinity control for the states is funded 75 percent by the federal government, and 25 percent by hydroelectric revenues. The augmentation of Colorado River water by importation of water from northern California and the Pacific Northwest was rejected. The 7 basin states use the Colorado River Basin Salinity Control Forum as a voluntary interstate planning entity for drawing up standards and plans of implementation. The plan recommends state action in urging industrial use of saline water, irrigation systems improvements, and studies to minimize salinity of municipal discharges. The plan does not recommend mandatory controls on irrigation or land use. National economic efficiency has been subordinated to political equity and income redistribution.

604. Johnson, V.H., 1952, Thermal metamorphism and ground water alteration of coking coal near Paonia, Colorado: Mining Engineering, v. 4, no. 4, p. 391-395. 
605. Jones, J.H., Jr., and Kunkel, Fred, 1974, Map of the Colorado River and Rio Grande Basins showing Indian reservations and pueblos and transbasin exportations of water: U.S. Geological Survey Open-File Report 74-0248, 1 sheet.

606. Jonez, A.R., 1984, Controlling salinity in the Colorado River Basin, the arid West, in French, R.H., ed., Salinity in watercourses and reservoirs, proceedings of the 1983 international symposium on state-of-the-art control of salinity, Salt Lake City, Utah, July 13-15, 1983: Stoneham, Mass., Butterworth Publishers, p. 337-347.

607. Jonez, A.R., 1986, Colorado River Water Quality Improvement Program, in Current technology the answer: National Water Supply Improvement Association Biennial Conference, 1st, Washington, D.C., June 8-12, 1986, Proceedings, p. 1-8.

608. Jonez, A.R., 1987, The hidden problem in the Colorado River; salt: Environmental Professional, v. 9, no. 1, p. 79-81.

The author gives a brief background on the problem in the basin and the progress which has been made toward controlling it.

609. Jonez, A.R., 1987, The salinity problem in the Colorado River Basin: ICID Bulletin, v. 36, no. 1, p. 33-37.

An overview is presented of the influences on salt input into the Colorado River and the consequent deterioration of water quality. Details are given of the remedial measures introduced to restore and maintain water quality and to limit pollutant discharge.

610. Jordan, D.S., 1891, Report of explorations in Colorado and Utah during the summer of 1889 with an account of the fishes found in each of the river basins examined: U.S. Fish. Comm. Bull. v.9, p. $1-40$.

611. Josberger, E.G., and Beauvillain, Edouard, 1989, Snow cover of the Upper Colorado River Basin from satellite passive microwave and visual imagery: Nordic Hydrology, v. 20, p. 73-84.

612. Josberger, E.G., Campbell, W.J., Gloersen, Per, and Chang, A.T.C., 1993, Satellite passive microwave observations of snow conditions in the Upper Colorado River Basin, in Kelmelis, J.A., and Snow, K.M., eds., Proceedings of the U.S. Geological Survey global change research forum, Herndon, Virginia, March 18-20, 1991: U.S. Geological Survey Circular 1086, p. 91.

613. Josberger, E.G., Ling, C.H., Campbell, W.J., Gloersen, Per, Chang, A.T.C., and Rango, A., 1989, Correlations of scanning multichannel microwave radiometer (SMMR) observations with snowpack properties of the Upper Colorado River Basin for water year 1986 in Remote sensing--An economic tool for the nineties: Canadian symposium on remote sensing, IGARSS '89, 12th, Vancouver, B.C., 1989, Proceedings, v. 12, no. 2, p. 1239-1242.

614. Joseph, T.W., 1977, Annotated bibliography of natural resource information, northwestern Colorado: U.S. Fish and Wildlife Service Report FWS/OBS-77/35, 184 p. 
615. Joseph, T.W., Sinning, James, Behnke, Robert, and Holden, Paul, 1977, An evaluation of the status, life history, and habitat requirements of endangered and threatened fishes of the Upper Colorado River system, part two: U.S. Fish and Wildlife Service Report FWS/OBS-77/62, $193 \mathrm{p}$. [Available from National Technical Information Service, Springfield, VA 22161 as NTIS Report PB-279 545/8.]

The focus of this report are the endangered and threatened fishes, but a full appreciation would not be possible without an adequate knowledge of the ecosystems in which they live. The six major sections of the report are: abiotic components, biological components, species description, river basin descriptions, major factors inducing environmental change, and urgent needs and recommended research priorities.

616. Joseph, T.W., Sinning, James, Behnke, Robert, and Holden, Paul, 1977, An indexed, annotated bibliography of the endangered and threatened fishes of the Upper Colorado River system, part one: U.S. Fish and Wildlife Service Report FWS/OBS-77/61, 170 p. [Available from National Technical Information Service, Springfield, VA 22161 as NTIS Report PB-279 544/1.]

The major emphasis of this bibliography lies with the threatened and endangered fishes of the Upper Colorado River system: their limiting factors, habitat alteration, and the numerous environmental factors associated with them. It includes subject, geographic, and systematic indexes.

617. Kaback, D.S., 1976, Transport of molybdenum in mountainous streams, Colorado: Geochimica et Cosmochimica Acta, v. 40, no. 6, p. 581-582.

618. Kaback, D.S., and Runnells, D.D., 1980, Geochemistry of molybdenum in some stream sediments and waters: Geochimica et Cosmochimica Acta, v. 44, no. 3, p. 447-456.

619. Kaeding, L.R., and Osmundson, D.B., 1988, Interaction of slow growth and increased early-life mortality; a hypothesis on the decline of Colorado squaw fish in the upstream regions of its historic range: Environmental Biology of Fishes, v. 22, no. 4, p. 287-298.

Ptychocheilus lucius, the principal native piscivore of the Colorado River basin, was once widespread and abundant in large rivers and their major tributaries. It occurs today only in the upstream regions of its historic range and is threatened with extinction. Growth rate there is much slower than the rate that might once have been typical in lower-basin rivers. Interaction of slow growth and increased early-life mortality is probably an important cause of the decline of Colorado squawfish in the upper basin. The unusually small size of the age-0 fish going into winter might be an important factor affecting recruitment to the adult stock. Simulations showed how the effect on increased early-life mortality can be especially significant on populations of slow-growing fishes. Predation by introduced fishes, as well as other man-induced causes of increased early-life mortality, probably contributed importantly to the decline of Colorado squaw fish in the remaining habitat. Management efforts that might help this endangered species to recover include water management to enhance temperatures for growth, and the control of important introduced fishes. 
620. Kaeding, L.R., and Osmundson, D.B., 1989, Biologically defensible flow recommendations for the maintenance and enhancement of Colorado squaw fish habitat in the '15-mile' reach of the Upper Colorado River during July, August and September: Grand Junction, Colo., U.S. Fish and Wildlife Service, $169 \mathrm{p}$.

621. Kaeding, L.R., and others, 1986, Recent capture of a bonytail (Gila elagans) and observations on this nearly extinct cyrinid from the Colorado River: Copeia, v. 4, p. 1021-1023.

622. Kahan, A.M., 1970, Weather modification potential for water supply in the Colorado River Basin: Denver, Colo., Bureau of Reclamation, 36 p.

623. Kansgen, A.C., 1930, Geography of the Gunnison region, Colorado: Boulder, Colo., University of Colorado, Master's thesis, $57 \mathrm{p}$.

624. Kapp, J.F., and Kroner, R.C., 1967, Trace elements in waters of the United States--A five-year summary of trace metals in rivers and lakes of the United States (Oct. 1, 1962-Sept. 30, 1967): Cincinnati, Ohio, U.S. Federal Water Pollution Control Administration, 32 p. plus 12 appendices.

625. Kappus, U., 1982, Water management strategies for energy development in the Western United States: Engineering Bulletin, v. 61, p. 25-30.

626. Keller, G.V., 1974, Geophysics of Colorado and geothermal energy, in Proceedings of a symposium on geothermal energy and Colorado: Denver, Colo., Colorado Geological Survey Bulletin 35, p. 31-43.

627. Kepinski, J., and Pajewski, R., 1978, Protection of Colorado (USA) waters against oversalting: Gospod. Wodna, v. 38, no. 11, p. 340-342.

628. Keys, J.W., III, 1978, The Colorado River salinity control program [abs.]: EOS, American Geophysical Union Transactions, v. 59, no. 12, p. 1064.

629. Keys, J.W., III, 1981, Grand Valley irrigation return flow case study: American Society of Civil Engineers, Joumal of the Irrigation and Drainage Division, v. 107, no. IR2, p. 221-232.

Irrigation water supply is furnished annually to about 71,500 acres (28,932 ha) of land in the Grand Valley of western Colorado. Return flows from that irrigation contribute about 780, 000 tons of salt to the Colorado River each year, causing an increase of $77 \mathrm{mg} / \mathrm{L}$ in the salinity concentration at Imperial Dam. This case study for the ASCE Task Committee on Water Quality Programs Affecting Agricultural Return Flows in Arid Areas is centered around three areas: physical and water quality data for irrigation and return flows in the valley, identification of regulations that affect this irrigation and its return flows, and the proposed program for controlling salinity contributions from the valley to the Colorado River. With water quality standards that have been established for the Colorado River and the continued development of water resources in the basin, a salinity control program for Grand Valley is needed.

630. Kidd, G.T., 1977, An investigation of endangered and threatened fish species in the Upper Colorado River as related to Bureau of Reclamation projects: Clifton, Colo., Northwest Fisheries Research, 37 p. 
631. Kimball, B.A., in press, Geochemistry of water in principal aquifers and confining units in the Upper Colorado River Basin in Arizona, Colorado, New Mexico, and Wyoming: U.S. Geological Survey Professional Paper 1411-G.

632. King, D.L., 1984, Grand Valley Stage One monitoring plan and implementation, in French, R.H., ed., Salinity in watercourses and reservoirs, proceedings of the 1983 international symposium on state-of-the-art control of salinity, Salt Lake City, Utah, July 13-15, 1983: Stoneham, Mass., Butterworth Publishers, p. 295-304.

633. Kinnear, B.S., 1967, Fishes of the Black Canyon: Fort Collins, Colo., Colorado State University, Master's thesis, $52 \mathrm{p}$.

634. Kinnear, B.S., and Vincent, R.E., 1967, Fishes of the Black Canyon of the Gunnison National Monument (completion report to U.S. National Park Service): Fort Collins, Colo., Colorado State University, $45 \mathrm{p}$.

635. Kinney, W.L., Brecheisen, A.N., and Lambou, V.W., 1979, Surface water quality parameters for monitoring oil shale development (final report): U.S. Environmental Protection Agency Report EPA/600/4-79/018, 156 p. [Available from National Technical Information Service, Springfield, VA 22161 as NTIS Report PB-297 984/7.]

This report develops and recommends prioritized listings of chemical, physical, and biological parameters which can be used to assess the environmental impact of oil shale development on surface water resources. Each of the potential water-related problems is addressed in the context of the probable cumulative regional impact of a maturing, commercial oil shale industry and in terms of local impact resulting from the prototype operation initially planned on leased public lands. The possible effects of potential pollutants on ambient water quality and the resulting impact on aquatic life, public water supplies, livestock, irrigation agriculture, and selected industries are evaluated.

636. Kircher, J.E., 1985, Dissolved solids in the Colorado River Basin, in U.S. Geological Survey, National water summary 1984--Hydrologic events, selected water-quality trends, and groundwater resources: U.S. Geological Survey Water-Supply Paper 2275, p. 74-78.

637. Kircher, J.E., Choquette, A.F., and Richter, B.D., 1985, Estimation of natural streamflow characteristics in western Colorado: U.S. Geological Survey Water-Resources Investigations Report 85-4086, 28 p.

638. Kircher, J.E., Dinicola, R.S., and Middelburg, R.M., 1984, Trend analysis of salt load and evaluation of the frequency of water-quality measurements for the Gunnison, the Colorado, and Dolores Rivers in Colorado and Utah: U.S. Geological Survey Water-Resources Investigations Report 84-4048, 74 p.

639. Kirk, C.L., Byrd, W.J., Dow, R.L., and others, 1981, Bibliography of theses and dissertations on Colorado, 1968-1980: Mountain Geologist, v. 18, no. 4, p. 96-113.

640. Kittel, G.M., Neely, B.E., Bourgeron, P., and Reid, M., 1992, Riparian wetland community types of 3 major river drainages within the Upper Colorado River Basin, Colorado [abs.]: Ecological Society of America Bulletin, v. 73, p. 231. 
641. Kittel, G.M., Rondeau, R., and Lederer, N., 1994, A classification of the riparian vegetation of the White and Colorado River Basins, Colorado: Fort Collins, Colo., The Nature Conservancy, Colorado Natural Heritage Program, 166 p.

642. Kleinman, A.P., and Brown, F.B., 1980, Colorado River salinity--Economic impacts on agricultural, municipal, and industrial users: Denver, Colo., Water and Power Resources Service, 25 p. [Available from National Technical Information Service, Springfield, VA 22161 as NTIS Report PB-81 186 900.]

Evaluation of the impacts of water quality in the Colorado River is of increasing concern to policymakers, resource planners, and the general public. As development and utilization of this resource continue, the quality of water will degrade, resulting in increased negative impacts. Until recently, evaluation of the impacts associated with changing levels of TDS (total dissolved solids) has not been included in economic analyses of future water-related projects. In 1974, Water and Power (Water and Power Resources Service of the Bureau of Reclamation) economists prepared a preliminary analysis of the economic impacts of salinity in the Colorado River Basin. Major salinity impacts were identified and evaluated. The results of these analysis are intended to enable Water and Power and other planners to better account for the impacts of salinity in the future.

643. Knight, A.W., 1965, Studies of the stoneflies (Plecoptera) of the Gunnison River drainage in Colorado: Salt Lake City, Utah, University of Utah, Ph.D. dissertation, 155 p.

644. Knight, A.W., and Argyle, D.W., 1962, Limited limnological studies of the Gunnison River, Colorado, in Pendergast, D.M., ed., Ecological studies of the flora and fauna of the Curecanti Reservoir basins, western Colorado: Salt Lake City, Utah, University of Utah Anthropological Paper 59, Upper Colorado Series 8, p. 135-149.

645. Kondrat'yeva, T.I., and Gorshkov, S.P., 1979, Basseyn Kolorado stanovitsya oblast'yu vnutrennego stoka. (The Colorado Basin becoming a region of interior drainage): Priroda, no. 10, p. $76-81$.

646. Kondrat'yeva, T.I., and Gorshkov, S.P., 1979, Transformation of the sediment and ionic runoff of the Colorado River under the effect of anthropogenic factors: Water Resour., v. 6, no. 3, p. 446-453.

647. Krieger, R.A., Hatchett, J.L., and Poole, J.L., 1957, Preliminary survey of the saline-water resources of the United States: U.S. Geological Survey Water-Supply Paper 1374, 172 p.

648. Kron, A., and Heiken, G., 1980, Geothermal gradient map of the United States, in Geothermal-Energy for the eighties, Transactions, Geothermal Resources Council annual meeting, Salt Lake City, Utah: Davis, Calif., Geothermal Resources Council, p. 69-71.

649. Krueger, R.P., 1988, Heavy metal analysis of seven Colorado squawfish from the Colorado and White Rivers: Grand Junction, Colo., U.S. Fish and Wildlife Service. 
650. Krueger, R.P., Thompson, Andrew, and Campbell-Osmundson, B. [Osmundson, B.C.], 1991, Big river fishes--Environmental contaminants in fish species used as surrogates for threatened and endangered fish of the Colorado River Basin, interim report: Grand Junction, Colo., U.S. Fish and Wildlife Service, 13 p.

651. Kruse, E.G., ed., 1977, Alleviation of salt load of irrigation water return flow of the Upper Colorado River Basin [final report]: Fort Collins, Colo., Agricultural Research Service, 136 p. plus appendix.

652. Kruse, E.G., 1978, Groundwater and salinity in the Grand Valley of Colorado, in 1978 winter meeting of the American Society of Agricultural Engineers, Chicago, December 18-20, 1978, [Proceedings?]: Chicago, Ill., American Society of Agricultural Engineers, p. 21.

653. Kruse, E.G., 1979, Surface irrigation systems for mountain meadows: Symposium for Management of Intermountain Meadows sponsored by the University of Wyoming and Colorado State University, Jackson, Wyo., June 1979, Proceedings, p. 29-52.

654. Kruse, E.G., 1980, Groundwater and salinity in the Grand Valley of Colorado: American Society of Agricultural Engineers Transactions, v. 23, no. 5, p. 1178-1188.

655. Kruse, E.G., Champion, D.F., Cuevas, D.L., Yoder, R.E., and Young, D.A., 1991, Crop water use from high, saline water tables [written for presentation at 1991 international summer meeting, American Society of Agricultural Engineers, Albuquerque, N. Mex., June 23-26, 1991]: St. Joseph, Mich., American Society of Agricultural Engineers Paper 91-2120, 29 p.

656. Kruse, E.G., Champion, D.F., Cuevas, D.L., Yoder, R.E., and Young, D.A., 1993, Crop water use from shallow, saline water tables: American Society of Civil Engineers Transactions, v. 36, no. 3, p. 697-707.

657. Kruse, E.G., Champion, D.F., and Yoder, R.E., 1991, High saline water-table effect on wheat irrigation, in Lysimeters for evapotranspiration and environmental measurements, proceedings of the international symposium on lysimetry, Honolulu, Hawaii, July 23-25, 1991: New York, N.Y., American Society of Civil Engineers, p. 335-343.

658. Kruse, E.G., Champion, D.F., Young, D.A., and Kincaid, D.C., 1984, Level-basin irrigation in the Upper Colorado River Basin, in Proceedings, XII Congress, International Commission on Irrigation and Drainage, New Delhi, India: International Commission on Irrigation and Drainage, p. 449-463.

659. Kruse, E.G., and Haise, H.R., 1974, Effectiveness of precipitation in a mountain meadow, in Proceedings of the Irrigation and Drainage Division Speciality Conference, American Society of Civil Engineers, Fort Collins, Colo., Aug. 22-24, 1973: New York, N.Y., American Society of Civil Engineers, p. 627-646.

660. Kruse, E.G., and Haise, H.R., 1974, Water use by native grasses in high altitude Colorado meadows: U.S. Department of Agriculture Report ARS-W-6, 60 p. 
661. Kruse, E.G., Kundu, S.S., Young, D.A., and Champion, D.F., 1982, Irrigation water use in western Colorado Ipaper presented at 1982 summer meeting, American Society of Agricultural Engineers, University of Wisconsin, Madison, Wis., June 27-30, 1982]: St. Joseph, Mich., American Society of Agricultural Engineers Paper 82-2045, 23 p.

662. Kruse, E.G., Young, D.A., and Champion, D.F., 1984, Effects of high, saline water tables in reducing irrigation requirements of crops, in Proceedings, XII Congress, International Commission on Irrigation and Drainage, New Delhi, India: International Commission on Irrigation and Drainage, p. 199-214.

663. Kruse, E.G., Young, D.A., and Champion, D.F., 1985, Effects of saline water tables on corn irrigation, in Proceedings of the American Society of Civil Engineers Irrigation and Drainage Division Speciality Conference [on] development and management aspects of irrigation and drainage systems, San Antonio, Tex., July, 1985: New York, N.Y. American Society of Civil Engineers, p. 444-453.

664. Kuhn, Gerhard, and Parker, R.S., 1992, Transfer of watershed-model-parameter values to noncalibrated basins in the Gunnison River Basin, Colorado, in Herrmann, R., ed., Proceedings of the American Water Resources Association Symposium on managing water resources during global change, Reno, Nevada, November 1-5, 1992: Bethesda, Md., American Water Resources Association Technical Publication Series TPS-92-4, p. 741-750.

665. Kuhn, T.H., 1982, The Gunnison city irrigation system--A study in bacteriological water quality and possible effects upon the community: Gunnison, Colo., Western State College, Master's thesis.

666. Kunkle, S., Nickerson, R., Smillie, G.M., and Andrascik, R., 1983, Metal concentrations in fish at Curecanti National Recreation Area, Gunnison, Colorado: Fort Collins, Colo., U.S. Department of the Interior National Park Service, Water Resource Field Support Laboratory Report 83-3-P, $33 \mathrm{p}$.

667. Kuo, M., and Cox, S.K., 1975, Analysis of Colorado precipitation: Fort Collins, Colo., Colorado State University Environmental Resources Center Completion Report 63, 36 p.

668. Kurey, W.J., 1985, Analysis of Colorado squawfish tissues of metal, organochlorine, and petroleum hydrocarbon residues: Grand Junction, Colo., U.S. Fish and Wildlife Service.

669. Kurey, W.J., 1985, Organochlorine contaminants in fish of the Grand Valley: Grand Junction, Colo., U.S. Fish and Wildlife Service.

670. LaBaugh, J.W., and Winter, T.C., 1984, The impact of uncertainties in hydrologic measurement on phosphorus budgets and empirical models for two Colorado reservoirs: Limnology and Oceanography, v. 29, no. 2, p. 322-339.

671. Lakes, Arthur, 1905, Geology of the hot springs of Colorado and speculations as to their origin and heat: Denver, Colo., Colorado Scientific Society Proceedings, v. 8, p. 31-37. 
672. Lane, W.L., 1991, Synthetic streamflows for global climate change, in Kirby, W.H., and Weiyan, Tan, comps., Proceedings of the United States--People's Republic of China bilateral symposium on droughts and arid-region hydrology, Tucson, Arizona, September 16-20, 1991: U.S. Geological Survey Open-File Report 91-244, p. 235-240.

673. Langbein, W.B., and Dawdy, D.R., 1964, Occurrence of dissolved solids in surface waters in the United States, in chap. D of Geological Survey research 1964: U.S. Geological Survey Professional Paper 501-D, p. D115-D117.

674. Langlois, D., Torres, J., Prewitt, C.G., Wick, E., Carlson, C., and Synder, D., 1978, Colorado squawfish and humpback chub population and habitat monitoring program: Denver, Colo., Colorado Division of Wildlife, Performance Report, Endangered Wildlife Investigations SE-3-1, $57 \mathrm{p}$.

675. Laronne, J.B., 1977, Dissolution potential of surficial Mancos Shale and alluvium: Fort Collins, Colo., Colorado State University, Ph.D. dissertation, 144 p. [Available from National Technical Information Service, Springfield, VA 22161 as NTIS Report PB-291 464/6.]

The objectives of this study were to determine the salt content of Mancos Shale and associated alluvium and the release mechanisms of salt from these deposits. When mixed with distilled water, the time necessary to approach equilibrium decreased with an increase of salt content and with a decrease of sediment concentration, and the time span required for equilibrium ranged from a few minutes to several days. The chemical quality of the aqueous mixtures was of the $\mathrm{Ca}^{2+}-\mathrm{Mg}^{2+}-\mathrm{Na}^{+}-\mathrm{SO}_{4}{ }^{2-}-\mathrm{HCO}_{3}$ type. Sodium and magnesium hydrated sulfates appeared to dissolve faster than gypsum or calcite, and the relative abundance of $\mathrm{Na}^{+}, \mathrm{Mg}^{2+}$, and $\mathrm{SO}_{4}{ }^{2-}$ decreased with increased dilution. There is a large inherent variability in the salt content of sampled sediments. Terrace and bed materials in narrow valleys where shallow alluvium overlies shale are highly saline (1.6 percent) and show an increase in salt content with depth. The results also show that major areas of diffuse sources of salts are also the major sediment contributors in the Upper Colorado River Basin.

676. Laronne, J.B., 1982, Sediment and solute yield from Mancos Shale hillslopes, Colorado and Utah, in Bryan, R.B., and Yair, A., eds., Badland geomorphology and piping: Norwich, England, Geo Books, p. 181-193.

677. Laronne, J.B., and Schumm, S.A., 1977, Evaluation of the storage of diffuse sources of salinity in the Upper Colorado River Basin: Bureau of Reclamation Report OWRT-B-121-COLO(2), 127 p. [Available from National Technical Information Service, Springfield, VA 22161 as NTIS Report PB-273 606/4. Also published through Colorado State University, Fort Collins, as Colorado Water Resources Research Institute Completion Report CR 79.]

The objectives were to determine the salt content of Mancos Shale and associated alluvium and the release mechanisms of salt from these deposits. When mixed with distilled water, the time necessary to approach equilibrium decreased with an increase of salt content and with a decrease of sediment concentration, and the time span required for equilibrium ranged from a few minutes to several days. The chemical quality of the aqueous mixtures was of the $\mathrm{Ca}^{2+}-\mathrm{Mg}^{2+}-\mathrm{Na}^{+}-\mathrm{SO}_{4}{ }^{2-}-\mathrm{HCO}_{3}$ type. There is a large inherent variability in the salt content of sampled sediments. Soluble mineral content of Mancos Shale from hillslopes (2 percent) is significantly larger than 
that of terrace alluvium (0.62-0.29 percent) and bed materials (0.93-0.81 percent) of North Miller and West Salt creeks, respectively. The most saline deposits (10 percent) are efflorescent bed crusts. Terrace and bed materials in narrow valleys where shallow alluvium overlies shale are highly saline (1.6 percent) and show an increase in salt content with depth. The results also show that major areas of diffuse sources of salts are also the major sediment contributors in the Upper Colorado River Basin.

678. Laronne, J.B., and Schumm, S.A., 1982, Soluble mineral content in surficial alluvium and associated Mancos Shale: Water Resources Bulletin, v. 18, no. 1, p. 27-35.

679. Laronne, J.B., and Shen, H.W., 1982, Temporal and spatial variations of solute pickup during runoff generation in saline hillslopes, in Singh, V.P., ed., Modeling components of hydrologic cycle: Littleton, Colo., Water Resources Publications, p. 449-462.

680. Larson, E.E., Bradley, W.C., and Ozima, M., 1975, Development of the Colorado River system in northwestern Colorado during the late Cenozoic, in Fassett, J.E., ed., Canyonlands country, a guidebook of the Four Corners Geological Society, 8th field conference, Sept. 22-25, 1975 : Durango, Colo., Four Corners Geological Society, p. 97-102.

681. Larson, E.E., Ozima, M., and Bradley, W.C., 1975, Late Cenozoic basic volcanism in northwestern Colorado and its implications concerning tectonism and the origin of the Colorado River system. in Curtis, B., ed., Cenozoic history of the Southern Rocky Mountains: Boulder, Colo., Geological Society of America Memoir 144, p. 155-178.

682. Larson, J.C., and Beetem, W.A., 1970, Chemical and radiochemical analyses of water from streams, reservoirs, wells and springs in the Rulison Project area, Garfield and Mesa Counties, Colorado: U.S. Geological Survey Open-File Report, 16 p.

683. La Rue, E.C., 1916, Colorado River and its utilization: U.S. Geological Survey Water-Supply Paper 395, 231 p.

684. Lavender, D., 1976, The role of water in the history and development of Colorado: Denver Journal of International Law and Policy, v. 6, p. 407-414.

685. Lavender, D., 1982, Colorado River country: New York, N.Y., E.P. Dutton, 238 p.

686. Law, J.P.J., and Hornsby, A.G., 1982, Colorado River salinity problem, in Water and energy development in an arid environment--The Colorado River Basin: Water Supply and Management, v. 6, no. 1-2, p. 87-104.

Much of the salt loading in the Colorado River occurs in the Upper Basin, with most of the resulting damages occurring in the Lower Basin. In the Upper Basin, only 2 percent of the salt loading is from municipal and industrial uses, 9 percent from natural point sources, 37 percent from irrigated agriculture, and 52 percent from natural diffuse sources. Natural point sources can be remedied by collecting and treatment or disposal. The most cost-effective technologies for irrigated agriculture are: better irrigation methods combined with improved on-farm water management practices in order to reduce deep percolation losses, and channel lining losses from canal laterals. 
687. Lawrence, F.F., 1953, Water-power resources of Crystal River, Colorado: U.S. Geological Survey Circular 292, 17 p.

688. Lawrence, K., 1974, The political and legal aspects of streamflows in Colorado: Boulder, Colo., prepared in cooperation with the Denver Water Board on [and?l the Western Interstate Commission for Higher Education, $76 \mathrm{p}$.

689. Leaf, C.F., 1966, Sediment yields from high mountain watersheds, central Colorado: U.S. Department of Agriculture, Forest Service Research Paper RM-23, 20 p.

A study of annual sediment yields from one carefully logged and two undisturbed watersheds in the Fraser Experimental Forest showed good correlation between peak streamflow and accumulated sediment volume. The relationships indicate that a major part of the sediment load is derived from channel erosion. The effects of logging on sediment yields are discussed, and magnitude-frequency relationships are developed for estimating long-term sediment yields.

690. Leaf, C.F., 1970, Sediment yields from the central Colorado snow zone: American Society of Civil Engineers, Journal of the Hydraulics Division, v. 96, no. HY1, p. 87-93.

To determine the effects of roads and forest-cover changes on sediment yields, measurements were made on one carefully logged and two undisturbed watersheds in the Fraser Experimental Forest, Colorado. Annual sediment yield averaged 200 pounds per acre immediately following road construction in 1950-52 and logging in 1954-56. In the period 1958-66, sediment yield averaged 43 pounds per acre, despite an estimated 25 percent increase in annual runoff caused by the harvest, compared with yields of 11 and 21 pounds per acre on the undisturbed watersheds.

691. Leaf, C.F., 1971, Areal snow cover and disposition of snowmelt runoff in central Colorado: U.S. Department of Agriculture, Forest Service Research Paper RM-66, 25 p.

Areal snow-cover depletion and resultant snowmelt and water yield were studied on three small watersheds in the Fraser Experimental Forest. High water yield efficiencies were observed on two watersheds which had (1) almost complete snow cover when seasonal snowmelt rates on all major aspects were maximum; (2) a delayed and short snow-cover depletion season; and (3) moderate recharge and evapotranspiration losses. Water yield efficiency in one watershed with low-elevation south slopes was least. In 1969, streamflow from the drainage area on this basin below 9,850 feet was less that 30 percent of that generated from above this elevation. Fourteen years of comparative streamflow indicated that water yields from the lowelevation subdrainage can vary from near zero in poor runoff years to a maximum during good years of about 50 percent of the flow generated from the high-elevation subdrainage.

692. Leaf, C.F., 1971, Sediment yields from central Colorado snow zone: American Society of Civil Engineers, Journal of the Hydraulics Division, v. 97, no. HY2, p. 350-351.

Specific weight (dry unit weight) is summarized with sediment class and particle size for sediments deposited in small debris basins on three headwater streams at the 
Fraser Experimental Forest. The effects of vegetation removal on water yields from the Fool Creek Experimental Watershed are discussed.

693. Leaf, C.F., 1975, Watershed management in the central and southern Rocky Mountains-A summary of the status of our knowledge by vegetation types: U.S. Department of Agriculture, Forest Service Research Paper RM-142, 28 p.

The report summarizes a series of comprehensive reports on watershed management in five major vegetation zones: (1) the coniferous forest subalpine zone; (2) the Front Range ponderosa pine zone; (3) the Black Hills ponderosa pine zone; (4) the alpine zone; and (5) the big sagebrush zone. The study includes what is known about the hydrology of these lands, what hydrologic principles are important for multiresource management, and what additional information is needed for each vegetation type.

694. Leaf, C.F., 1975, Watershed management in the Rocky Mountain subalpine zone--The status of our knowledge: U.S. Department of Agriculture, Forest Service Research Paper RM-137, 31 p.

695. Leaf, C.F., and Brink, G.E., 1972, Annual streamflow summaries from four subalpine watersheds in Colorado: U.S. Department of Agriculture, Forest Service General Technical Report RM-1, 24 p.

696. League of Women Voters of Colorado, 1992, Colorado water: Denver, Colo., League of Women Voters of Colorado, $37 \mathrm{p}$.

697. Leathers, K.L., and Young, R.A., 1976, Evaluating economic impacts of programs for control of saline irrigation return flows--A case study of the Grand Valley, Colorado: U.S. Environmental Protection Agency Report EPA-68-01-2660, 178 p. [Available from National Technical Information Service, Springfield, VA 22161 as NTIS Report PB-265 842.]

Economic impacts of alternative on-farm water management programs for controlling saline irrigation return flows are estimated. The study focuses on the Grand Valley in west central Colorado, an area thought to be representative of irrigation return flow problems in the Upper Colorado River Basin. Direct economic impacts, in terms of increased cost or reduced incomes, are estimated with linear programming models of representative farm situations. A regional interindustry model was developed to trace indirect economic impacts on related economic sectors in the three-county local trade area. Since the hydrologic-geologic relationships which govern salt pick-up in the study reach area not entirely understood, a correlation and regression analysis of water quality and quantity data was performed. This analysis attempted to distinguish salt contributions of natural origin from those due to irrigation, and to separate irrigation concentrations into components attributable to on-farm irrigation practices as compared to water distribution system losses.

698. Leavesley, G.H., Branson, M.D., and Hay, L.E., 1992, Using coupled atmospheric and hydrologic models to investigate the effects of climate change in mountainous regions, in Herrmann, R., ed., Proceedings of the American Water Resources Association Symposium on managing water resources during global change, Reno, Nevada, November 1-5, 1992: Bethesda, Md., American Water Resources Association Technical Publication Series TPS-92-4, p. 691-700. 
699. Lee, D.J., Howitt, R.E., and Marino, M.A., 1993, A stochastic model of river water quality-Application to salinity in the Colorado River: Water Resources Research, v. 29, no. 12, p. 3917-3923.

This research combines mass transport theory with stochastic methods to derive a stochastic, variable flow, surface water quality model for water quality policy analysis. Steady-state flow assumptions and a series of differential equations reduce the information and number of equations required to completely specify the model. The newly developed hydrology model is applied to river salinity in the Colorado Basin to evaluate the effectiveness of alternative salt load reduction strategies in water quality management. Model results are used to illustrate the influence of salt load reduction, stochastic river flows, and water conservation on river water quality.

700. Leeds, H., 1953, Report on depletion of surface water supplies of Colorado west of the Continental Divide: Colorado Water Conservation Board Bulletin 1, Surface Water Series, $61 \mathrm{p}$.

701. LeGendre, G.R., 1973, Removal of molybdenum by ferric oxyhydroxide in Clear Creek and Tenmile Creek, Colorado: Boulder, Colo., University of Colorado.

702. Lemons, D.G., 1954, A field survey of western Colorado streams and lakes: Denver, Colo., Colorado Department of Game and Fish, $29 \mathrm{p}$.

703. Lester, O.C., 1918, The radioactive properties of the mineral springs of Colorado: American Journal of Science, 4th Series, v. 46, no. 275, p. 621-637.

704. Lewis, E.L., 1966, The thermal springs of Colorado--A resource appraisal: Boulder, Colo., University of Colorado, Master's thesis, $91 \mathrm{p}$.

705. Lewis, W.M., 1984, Eutrophication and land use, Lake Dillon, Colorado: Ecological Studies Series, v. 46, p., 193-198.

706. Lewis, W.M., Saunders, J.F., Crumpacker, D.W., and Brendecke, C., 1983, Dillion Clean Lakes Project: Denver, Colo., Denver Water Department[?].

707. Liebermann, T.D., Mueller, D.K., Kircher, J.E., and Choquette, A.F., 1989, Characteristics and trends of streamflow and dissolved solids in the Upper Colorado River Basin, Arizona, Colorado, New Mexico, Utah, and Wyoming: U.S. Geological Survey Water-Supply Paper 2358, $64 \mathrm{p}$.

708. Lindner-Lunsford, J.B., Kimball, B.A., Chafin, D.T., and Bryant, C.G., 1989, Hydrogeology of aquifers of Paleozoic age, Upper Colorado River Basin--excluding the San Juan Basin--in Colorado, Utah, Wyoming, and Arizona: U.S. Geological Survey Hydrologic Investigations Atlas HA-702, 2 sheets, scale 1:2,500,000 and 1:5,000,000.

709. Linstedt, K.D., 1968, Occurrence of vanadium in the Colorado River and its behavior in water treatment coagulation: Palo Alto, Calif., Stanford University, Ph.D. dissertation, 199 p.

710. Linstedt, K.D., and Kruger, P., 1969, Vanadium concentrations in Colorado River Basin waters: American Water Works Association Journal, v. 61, no. 2, p. 85-88. 
711. Litke, D.W., and Appel, C.L., 1989, Estimated use of water in Colorado, 1985: U.S. Geological Survey Water-Resources Investigations Report 88-4101, 157 p.

712. Litke, D.W., and Evans, N.A., 1990, Colorado water supply and use, in Carr, J.E., Chase, E.B., Paulson, R.W., and Moody, D.W., comps., National water summary 1987--Hydrologic events and water supply and use: U.S. Geological Survey Water-Supply Paper 2350, p. 183-192.

713. Livingston, R.K., 1970, Evaluation of the streamflow data program in Colorado: U.S. Geological Survey Open-File Report, $72 \mathrm{p}$.

714. Lohman, L.C., 1979, A preliminary analysis of the political tensions affecting planned reuse in the Colorado River Basin, in Water reuse--From research to application, proceedings, Water Reuse Symposium, March 25-30, 1979, Washington, D.C.: Denver, Colo., American Water Works Association Research Foundation, p. 1190-1202.

This paper draws from several years of study of the management strategies for the Colorado River and of the policy aspects of planned water reuse in the Colorado River Basin. One study, sponsored by the U.S. Environmental Protection Agency, Region VIII, focused on an analysis of state and local management actions which might be taken to reduce salinity in the Colorado River. The Office of Water Research and Technology sponsored another study which examined the system of control, planning and management of water resources in the semi-arid Colorado River region as it applies to planned reuse of that scarce resource. Unplanned reuse is a regular occurrence as the Colorado River flows over 1,400 miles of weathering soils and rocks before it enters Mexico. Increasing salinity, both from natural and man-created causes, as well as inadequate supplies to meet the demands of a developing region, are also factors in managing the Colorado River. Given these conditions it is likely that planned reuse of water in the Colorado River Basin might not only increase beneficial utilization of existing supplies, but might also improve water quality if known supplies of low quality water are tapped for consumptive reuse. The technological and economic problems of reuse of low quality water are the subject of much research and are fairly well identified. Legal barriers are identifiable, and are also the subject of specific research. It is the institutional barriers to planned reuse, as affected by the political processes supporting them, which have been scarcely examined. Management of the Colorado River's resources is in the hands of a number of federal and state agencies which have frequently incompatible goals and policies applicable to satisfying demands for water use and for water quality. Setting aside statutory obligations, the administrative policies and regulatory interpretations of these agencies which can encourage or impede planned reuse are supported by agency or individuals.

715. Lohman, L.C., and Milliken, J.G., 1981, Financial incentives for electric utilities to reuse low quality waters in the Colorado River Basin: Denver, Colo., Denver Research Institute, $17 \mathrm{p}$. [Available from National Technical Information Service, Springfield, VA 22161 as NTIS Report PB-82 222 340.] 
716. Lohman, L.C., Milliken, J.G., Dorn, W.S., and Tuccy, K.E., 1988, Estimating economic impacts of salinity of the Colorado River (final report): Littleton, Colo., Milliken Chapman Research Group, Inc., 96 p. [Available from National Technical Information Service, Springfield, VA 22161 as NTIS Report PB-88 211 594/XAB.]

The research is from a study designed to develop a method of forecasting economic impacts of salinity of the Colorado River upon various users of Colorado River water in the southwestern United States. One objective was to update, revise, clarify, and refine the estimates of economic damages from salinity in the Colorado River that had been described in earlier studies. Another objective was to provide a better means of estimating present and future salinity damages, basically through the development of a comprehensive and user-friendly personal computer program. A final objective addressed unresolved questions and issues about Colorado River salinity, including areas of damage not previously included in the estimates.

717. Lohman, S.W., 1961, Abandonment of the Unaweep Canyon, Mesa County, Colorado, by capture of the Colorado and Gunnison Rivers, in Short papers in the geologic and hydrologic sciences, chap. B of Geological Survey research 1961: U.S. Geological Survey Professional Paper 424-B, p. B144-B146.

718. Lohman, S.W., 1965, Geology and artesian water supply of the Grand Junction area, Colorado: U.S. Geological Survey Professional Paper 451, 149 p.

719. Lohman, S.W., 1981, Ancient drainage changes in and south of Unaweep Canyon, southwestem Colorado, in Epis, R.C., and Callender, J.F., eds., Western Slope, Colorado--Western Colorado and eastern Utah, New Mexico Geological Society, thirty-second field conference, Oct. 8-10, 1981: New Mexico Geological Society Guidebook 32, p. 137-143.

720. Longwell, C.R., 1946, How old is the Colorado River? American Journal of Science, v. 244, no. 12 , p. 817-835.

721. Lord, W.B., 1980, Institutional aspects of water allocation in the Upper Colorado River Basin-Implications for fish and wildlife, in Spofford, W.O., Jr., Parker, A.L., and Kneese, A.V., eds., Energy development in the Southwest, problems of water, fish and wildlife in the Upper Colorado River Basin, volume 2: Washington, D.C., Resources for the Future, Research Paper R-18, p. 487-514.

722. Lovejoy, E.M.P., 1964, Age of the Colorado River in the Colorado Plateau [abs.]: Geological Society of America Special Papers 76, p. 281.

723. Lovejoy, E.M.P., 1976, Pre-Pliocene river system development, Colorado Plateau and southern Rocky Mountains; a theory [abs.]: Geological Society of America Abstracts with Programs, v. 8, no. 5 , p. 603.

724. Lovejoy, E.M.P., 1977, Neogene Colorado River development in Colorado Plateau; a theory [abs.]: Geological Society of America Abstracts with Programs, v. 9, no. 4, p. 457.

725. Low, J.W., 1939, Plan and profile of Crystal River, Colorado, from Carbondale to Marble, dam site: U.S. Geological Survey, 2 sheets, scale 1:31,680. 
726. Lowardy, L.D., 1911, Unwatering the silver mines of Aspen: Mining and Scientific Press, v. 63, p. 388-390.

727. Lusby, G.C., 1965, Causes of variation in runoff and sediment load from small drainage basins in western Colorado, in Proceedings of the Federal interagency sedimentation conference, 1963:

U.S. Department of Agriculture, Agricultural Research Service Miscellaneous Publication 970, p. 94-98.

728. Lusby, G.C., 1970, Hydrologic and biotic effects of grazing versus nongrazing near Grand Junction, Colorado, in chap. B of Geological Survey research 1970: U.S. Geological Survey Professional Paper 700-B, p. B232-B236. [Also published in Journal of Range Management, v. 23, no. 4, p. 256-260.]

729. Lusby, G.C., 1979, Effects of converting sagebrush cover to grass on the hydrology of small watersheds at Boco Mountain, Colorado: U.S. Geological Survey Water-Supply Paper 1532-J, $36 \mathrm{p}$.

730. Lusby, G.C., 1979, Effects of grazing on runoff and sediment yield from desert rangeland at Badger Wash in western Colorado, 1953-73: U.S. Geological Survey Water-Supply Paper 1532I, 34 p.

731. Lusby, G.C., Reid, V.H., and Knipe, O.D., 1971, Effects of grazing on the hydrology and biology of the Badger Wash Basin in western Colorado, 1953-66: U.S. Geological Survey Water-Supply Paper 1532-D, 90 p.

732. Lusby, G.C., Turner, G.T., Thompson, J.R., and Reid, V.H., 1963, Hydrologic and biotic characteristics of grazed and ungrazed watersheds of the Badger Wash Basin in western Colorado, 1953-58: U.S. Geological Survey Water-Supply Paper 1532-B, 73 p.

733. Lynch, T.M., 1957, A theorem for warm water classification: Denver, Colo., Colorado Department of Game and Fish, Project 7A, Progress Report, 9 p.

734. Maarouf, Abdelrahman, 1983, Relationship between basement faults and Colorado Plateau drainage, in Averett, W.R., ed., Northern Paradox Basin-Uncompahgre Uplift: Grand Junction, Colo., Grand Junction Geological Society, p. 59-62.

735. Macalady, D.L., Ranville, J.F., Smith, K.S., and Daniel, S.R., 1991, Adsorption of copper, cadmium, and zinc on suspended sediments in a stream contaminated by acid mine drainage-The effect of seasonal changes in dissolved organic carbon: Fort Collins, Colo., Colorado Water Resources Research Institute Completion Report CR 159.

736. Macalady, D.L., Smith, K.S., and Ranville, J.F., 1990, Acid mine drainage--Streambed sorption of copper, cadmium and zinc: Fort Collins, Colo., Colorado Water Resources Research Institute Completion Report CR 154.

737. MacDonnell, L.J., 1989, Water quality and water rights in Colorado: Fort Collins, Colo., Colorado Water Resources Research Institute Completion Report CR 151. 
738. Macko, C.A., 1984, Glenwood-Dotsero Springs salinity control project, in French, R.H., ed., Salinity in watercourses and reservoirs, proceedings of the 1983 international symposium on state-of-the-art control of salinity, Salt Lake City, Utah, July 13-15, 1983: Stoneham, Mass., Butterworth Publishers, p. 295-304.

739. MacLachlan, M.E., and Welder, F.A., 1987, Paleozoic and Mesozoic formations and their potential as ground-water reservoirs, in Taylor, O.J., comp., Oil shale, water resources, and valuable minerals of the Piceance Basin, Colorado--The challenge and choices of development: U.S. Geological Survey Professional Paper 1310, p. 95-106.

740. Maddux, H.R., Fitzpatrick, L.A., and Noonan, W.R., 1993, Colorado River endangered fishes critical habitat, draft biological support document: Salt Lake City, Utah, U.S. Fish and Wildlife Service, $225 \mathrm{p}$.

741. Major, T.J., Kerbs, Lynda, and Penley, R.D., 1975, Water-level records for Colorado, 1971-75: Colorado Water Resources Basic-Data Release 37, 356 p.

742. Maletic, J.T., 1974, Current approaches and alternatives to salinity management in Colorado River Basin, in Flack, J.E., and Howe, C.W., eds., Salinity in water resources, proceedings of the 15th annual Western Resources Conference, July 1973, University of Colorado: Boulder, Colo., Merriman, p. 11-29.

743. Maletic, J.T., 1974, Salinity control planning in the Colorado River system, in Hydrology and water resources, 1974 meeting, Arizona Section: Flagstaff, Ariz., American Water Resources Association and the Hydrology Section, Arizona Academy of Science, p. 108-126.

744. Mallory, E.C., Jr., and Barrett, P.R., 1973, Chemistry and spectrochemical analysis of selected groundwaters in Colorado: U.S. Geological Survey Open-File Report, 47 p.

745. Malone, R.F., Bowles, D.S., Grenney, W.J., and Windham, M.P., 1979, Stochastic analysis for water quality: Bureau of Reclamation Report OWRT-A-039-UTAH(2), 79 p. [Available from National Technical Information Service, Springfield, VA 22161 as NTIS Report PB-295 392/5.]

This report demonstrates the feasibility of applying stochastic techniques to linear water quality models. The Monte Carlo, First Order, and Generation of Moment Equation techniques are applied to a long term phosphorus model of Lake Washington. The effect of uncertainty of the phosphorus loading term on simulated phosphorus levels is analyzed. All three stochastic techniques produced the same results. The simulated concentrations of phosphorus in the water column are very responsive to uncertainty of annual phosphorus loading, the sediment concentrations relatively insensitive. The Monte Carlo technique requires the most computation time of the three stochastic techniques applied. The Generation of Moment Equation technique is also applied to a steady state salinity model of the Colorado River system. The major source of uncertainty in all simulations is the estimation of the steady state salinity loading with the agricultural loading term becoming important in some simulated management alternatives. 
746. Malone, R.F., Grenney, W.J., and Bowles, D.S., 1981, Reliability of salinity predictions for the Colorado River, in Jenkins, S.H., ed., The environmental impact of man's use of water, I, proceedings of a specialised conference of the International Association Water Pollution Research, Brighton, United Kingdom, Nov. 3-7, 1980: Water Science and Technology, v. 13, no. 6, p. 223-232.

The Colorado River is approximately $2,250 \mathrm{~km}$ long and drains an area of over $626,000 \mathrm{~km}^{2}$ in Utah, Wyoming, Colorado, Nevada, Arizona, and California. The combined effects of increased consumptive use and salt erosion from decomposed saline shale deposits have raised the salinity of the mainstream to a level which threatens downstream agricultural uses. $\Lambda$ stochastic model of the salinity distributions in the Colorado River was developed in order to predict the effects of proposed salinity control alternatives. The sources of system uncertainty were identified and the major source was found to be associated with estimating baseline salinity loadings from natural sources. Model results indicated that proposed changes in irrigation practices would significantly reduce salinity loading. The coefficients of variation on model predictions ranged from 5.7 to 10.3 percent. The results of the stochastic model were compared with those from a previously applied deterministic model.

747. Mann, D.E., 1975, Conflict and coalition--Political variables underlying water resource development in the Upper Colorado River Basin: Natural Resources Journal, v. 15, no. 1, p. 141-169.

748. Mann, D.E., 1975, Politics of basin-wide management in the Colorado River Basin [abs.]: Geological Society of America Abstracts with Programs, v. 7, no. 7, p. 1187-1188.

749. Mann, D.E., 1976, Water policy and decision-making in the Colorado River Basin: National Science Foundation Report NSF/RA-761128, 62 p. [Available from National Technical Information Service, Springfield, VA 22161 as NTIS Report PB-273 025/7.]

Traditional water policy in the Colorado River Basin has been under stress as new issues of water quality and energy development have arisen. Increasing salinity, demands from Mexico for improvements in the quality of water it receives from the basin, and 1972 water quality legislation have imposed new burdens on the decisionmaking system. The national demand for energy has led to competition for scarce water supplies and has threatened the existing pattern of resource use and style of living. The western state public and their leaders appear to accept energy development but fear the consequences both for the environment and for their communities. The traditional politics of water development projects remains a strong feature of present decision-making, but there are significant weaknesses in the orientation and focus. There exists numerous organizations in the Rocky Mountain states and the Colorado River Basin that provide leadership and mobilize interests, but these organizations must be strengthened in order to meet the present political, environmental, and social challenges.

750. Mann, D.E., Weatherford, G.D., and Nichols, Phillip, 1974, Legal-political history of water resource development in the Upper Colorado River Basin: University of California Lake Powell Research Project Bulletin 4, 53 p. 
751. Mara, S.J., 1974, Quantification of land disturbance from oil shale development and resulting impacts on the Upper Colorado River Basin [abs.]: Geological Society of America Abstracts with Programs, v. 6, no. 7, p. 856.

752. Markoff, D.R., 1966, History of the Gunnison Waterworks since 1906: Gunnison, Colo., Western State College, Master's thesis, $98 \mathrm{p}$.

753. Marlatt, William, and Riehl, Herbert, 1963, Precipitation regimes over the Upper Colorado River: Fort Collins, Colo., Colorado State University 4 PT. 1, 7 p. [Available from National Technical Information Service, Springfield, VA 22161 as NTIS Report AD-442 136/8.]

To study certain aspects of the climatology of precipitation integrated over the Colorado River Basin, daily precipitation values recorded at weather stations in the basin were summed with an area weighting method to yield daily mean basin value. Several checks were performed to test the reliability of the procedure with in the limits needed for this analysis. A good correlation was obtained between computed annual precipitation and annual river discharge. It was found that $50 \%$ of annual precipitation is produced by 16 per cent of the number of days having precipitation per year (about 260). A correlation exists between daily precipitation and fraction of area receiving precipitation, so that large amounts of basin integrated precipitation were derived from widespread precipitation over the whole basin. This relation holds for both summer and winter, even though the type of clouds producing precipitation changes from altostratus in winter to cumulus in summer. The variance of annual precipitation is caused by passing synoptic-scale weather disturbances. The numerous days with precipitation less than 0.10 inch do not contribute to the variance and may be reckoned as noise.

754. Marlatt, William, and Riehl, Herbert, 1963, Precipitation regimes over the Upper Colorado River: Journal of Geophysical Research, v. 68, no. 24, p. 6447-6458.

755. Mars, J.P., 1979, Water quality investigations of Gore Creek, August 1977 through January 1978 : Denver, Colo., Colorado Department of Health, $20 \mathrm{p}$.

756. Mars, J.P., 1979, Water quality investigations of the Fraser River, September 1977 through January 1978: Denver, Colo., Colorado Department of Health, 27 p.

757. Mars, J.P., 1980, Heavy metals problems on the Snake River drainage, June through September, 1978: Denver, Colo., Colorado Department of Health, 17 p.

758. Marsh, B.W., 1905, The Uncompahgre Valley and the Gunnison Tunnel--A description of scenery, natural resources, products, industries, exploration, adventure: Gunnison, Colo., Marsh and Torrence, $13 \mathrm{p}$.

759. Marsh, W.R., and Queen, R.W., 1974, Map showing localities and amounts of metallic mineral production in Colorado: U.S. Geological Survey Mineral Investigations Resource Map MR-58, scale 1:500,000.

760. Marston, Ed, 1986, Reworking the Colorado River Basin: High Country News, v. 18, no. 21, p. 18. 
761. Martin, L., and Prestel, M., 1991, Annual report on the biological assessment of the Eagle River Superfund Site, Eagle County, Colorado: Colorado Division of Wildlife, $40 \mathrm{p}$.

762. Martin, R.O.R., and Hanson, R.L., 1966, Reservoirs in the United States: U.S. Geological Survey Water-Supply Paper 1838, 115 p.

763. Mason, D., 1993, Salinity--Colorado River water quality crisis, in Magoon, O.T., ed., Coastal zone '93, proceedings of the eighth symposium on coastal and ocean management, New Orleans, Louisiana, July 19-23, 1993: New York, N.Y., American Society of Civil Engineers.

The major concern cited is excessive salt concentrations caused by salt loading of return flows to the Colorado River. Salinity levels measured as milligrams per liter $(\mathrm{mg} / \mathrm{L})$ are monitored closely to ascertain if the United States is maintaining water quality standards established by the seven Basin states and approved by the Environmental Protection Agency (EPA). Title II of the Colorado River Basin Salinity Control Act is concerned specifically with implementing measures upstream from Imperial Dam to comply with the salinity standards. USDI, USDA and EPA are directed by Title II of this Act to coordinate their activities to carry out the objectives of this Title.

764. Maughan, W.D., 1978, Physical setting, in Peterson, D.F., and Crawford, A.B., eds., Values and choices in the development of the Colorado River Basin: Tucson, Ariz., University of Arizona Press, p. 9-17.

765. May, B.E., 1970, Oil shale development: Colorado Outdoors, v. 19, no. 4, p. 29-30.

766. Maynard, D.P., and Caputo, Richard, 1982, Assessment of saline water use in coal transport and multipurpose systems: Bureau of Reclamation Report JPL-D-425, 156 p. [Available from National Technical Information Service, Springfield, VA 22161 as NTIS Report PB-83 187633.$]$

This report describes an appraisal-level systems analysis of saline water transport methods. The analysis was performed to identify major technical/design/operational options, issues, and problem areas, and to investigate the economic feasibility of joint venture transport and use systems. This analysis is intended to assist in formulating a study to evaluate the use of saline water transport systems and effects on salinity control in the Colorado River Basin.

767. McAda, C.W., 1978, A catalog of water development in the Upper Colorado River Basin: Salt Lake City, Utah, U.S. Fish and Wildlife Service, 226 p. plus 38 maps.

768. McAda, C.W., Bates, J.W., Cranney, J.S., Chart, T.E., Elmblad, W.R., and Nesler, T.P., 1994, Interagency standardized monitoring program, summary of results, 1986-1992: Denver, Colo., U.S. Fish and Wildlife Service Recovery Implementation Program for the endangered fishes of the Upper Colorado River Basin, 73 p. and appendices.

769. McAda, C.W., and Kaeding, L.R., 1989, Relations between maximum-annual river discharge and the relative abundance of age- 0 Colorado squawfish in the Upper Colorado River, final report: Grand Junction, Colo., U.S. Fish and Wildlife Service. 
770. McAda, C.W., and Kaeding, L.R., 1991, Physical changes in the Gunnison and Colorado Rivers resulting from construction of the Aspinall Unit and related projects, with hypotheses to assess the effects on the endangered fishes, final report: Grand Junction, Colo., U.S. Fish and Wildlife Service, $60 \mathrm{p}$.

The purpose of this document is to: 1) describe changes in the Gunnison and Upper Colorado Rivers as a result of the Aspinall Unit and the two recent projects, and 2) to hypothesize how these changes have affected the native fish community. This information will be used to design studies to test these hypotheses and to assess the benefits for endangered fishes that could be achieved by reoperating the Aspinall Unit.

771. McCabe, G.J., Jr., 1994, Relationships between atmospheric circulation and snowpack in the Gunnison River Basin, Colorado: Journal of Hydrology, v. 157, no. 1-4, p. 157-175.

772. McCabe, G.J., Jr., and Hay, L.E., 1994, Hydrologic effects of hypothetical climate change in the East River Basin, Colorado, in Marston, R.A., and Hasfurther, V.R., eds., Proceedings, annual summer symposium of the American Water Resources Association, effects of human-induced changes on hydrologic systems, Jackson Hole, Wyoming, June 26-29, 1994: Bethesda, Md., American Water Resources Association Technical Publication Series TPS-94-3, p. 163-172.

773. McCain, J.F., and Jarrett, R.D., 1976, Manual for estimating flood characteristics of natural-flow streams in Colorado: Denver, Colo., Colorado Water Conservation Board Technical Manual 1, $68 \mathrm{p}$.

774. McCarthy, K.P., 1982, Geothermal implications of warm mine water drainage at Lake City and Cripple Creek, Colorado: Denver, Colo., Colorado Geological Survey Open-File Report 82-5, $15 \mathrm{p}$.

775. McCaull, J., 1974, Wringing out the West: Environment, v. 16, no. 7, p. 10-17.

776. McConaghy, J.A., 1966, A hydrogeologist looks at the 1965 Colorado ground-water law: Ground Water, v. 4, no. 2, p. 28-31.

777. McConaghy, J.A., and Colburn, G.W., 1964, Records of wells in Colorado: Denver, Colo., Colorado Water Conservation Board Basic-Data Report 17, $384 \mathrm{p}$

779. McDonald, J.W., 1980, Availability of water for oil shale development in the Upper Colorado River Basin, in Proceedings, 55th annual fall technical conference and exhibition: Dallas, Tex., Society of Petroleum Engineers of American Institute of Mining, Metallurgical, and Petroleum Engineers.

It is estimated that the water demands of an oil shale industry of about 1.5 million $\mathrm{bbl/day,} \mathrm{as} \mathrm{well} \mathrm{as} \mathrm{the} \mathrm{water} \mathrm{demands} \mathrm{of} \mathrm{the} \mathrm{associated} \mathrm{growth,} \mathrm{could} \mathrm{be} \mathrm{satisfied}$ from surface supplies without having to reduce significantly other existing or projected consumptive uses in the Upper Colorado River Basin. This conclusion is premised, however, on four major qualifiers which are examined in detail. Factors such as the availability of ground water and the impact of developing water supplies are outlined. 
780. McDowell-Smith \& Associates and McCall-Ellington \& Morrill, Inc., 1974, Waste load allocation for the Eagle River and Gore Creek: Denver, Colo., Colorado Department of Health, 34 p. plus appendices.

781. McGuiness, C.L., 1963, The role of ground water in the national water situation, with State summaries based on reports by district offices of the Ground-Water Branch: U.S. Geological Survey Water-Supply Paper 1800, 1121 p.

782. McGuiness, C.L., 1964, Generalized map showing annual runoff and productive aquifers in the conterminous United States: U.S. Geological Survey Hydrologic Investigations Atlas HA-194, scale 1:5,000,000.

783. McIntosh, W., 1977, An individualized approach to the development of a major river system; the Colorado River as an example: State College, Pa., Pennsylvania State University, Master's thesis, $79 \mathrm{p}$.

784. McKnight, D.M., and Bencala, K.E., 1988, Diel variations in iron chemistry in an acidic stream in the Colorado Rocky Mountains, USA: Arctic and Alpine Research, v. 20, no. 4, p. 492-500.

785. McKnight, D.M., and Bencala, K.E., 1989, Reactive iron transport in an acidic mountain stream in Summit County, Colorado--A hydrologic perspective: Geochimica et Cosmochimica Acta, v. 53 , no. 9 , p. $2225-2234$.

786. McKnight, D.M., and Bencala, K.E., 1990, The chemistry of iron, aluminum, and dissolved organic material in three acidic, metal-enriched, mountain streams, as controlled by watershed and in-stream processes: Water Resources Research, v. 26, no. 12, p. 3087-3100.

787. McKnight, D.M., Bencala, K.E., Zellweger, G.W., Alken, G.R., Feder, G.L., and Thorn, K.A., 1992, Sorption of dissolved organic carbon by hydrous aluminum and iron oxides occurring at the confluence of Deer Creek with the Snake River, Summit County, Colorado: Environmental Science and Technology, v. 26, no. 7, p. 1388-1396.

788. McKnight, D.M., and Feder, G.L., 1984, The ecological effect of acid conditions and precipitation of hydrous metal oxides in a Rocky Mountain stream: Hydrobiologia, v. 119, no. 2, p. 129-138.

789. McKnight, D.M., Smith, R.L., Harnish, R.A., Miller, C.L., and Bencala, K.E., 1993, Seasonal relationship between planktonic microorganisms and dissolved organic carbon in an alpine stream: Biogeochemistry, v. 21, no. 1, p. 39-59.

790. McKnight, D.M., Wershaw, R.L., Bencala, K.E., Zellweger, G.W., and Feder, G.L., 1992, Humic substances and trace metals associated with $\mathrm{Fe}$ and $\mathrm{Al}$ oxides deposited in an acidic mountain stream: Science of the Total Environment, 117/118, p. 485-498.

791. McNeal, J.M., Feder, G.L., Ringrose, C.D., and Klusman, R.W., 1976, Stream sediment chemistry in the oil-shale region, in Geochemical survey of the western energy regions (formerly Geochemical survey of the western coal regions), 3d annual progress report, July 1976: U.S. Geological Survey Open-File Report 76-729, p. 121-130. 
792. McWhorter, D.B., Skogerboe, R.K., and Skogerboe, G.V., 1975, Water quality control in mine spoils, Upper Colorado River Basin (environmental protection technology series):

U.S. Environmental Protection Agency Report EPA/670/2-75-048, 110 p. [Available from

National Technical Information Service, Springfield, VA 22161 as NTIS Report PB-242 908/2.]

The purpose of the study was to identify potential water quality problems associated with runoff and percolation through mine spoils at selected sites in the Upper Colorado River Basin. The results show that the production of soluble salts from mine spoils into receiving waters is probably the most significant water quality problem that can be expected. No significant release of heavy metal concentrations were observed in the stream below the tailings disposal area from a copper-lead-zinc mill. A portion of these metals are contributed by the tailings, but a variety of old mines and mine dumps also make a contribution. The quality and runoff from spoils was found to correspond to the constituents of extracts prepared from saturated pastes of the spoil material. A method of estimating salt production into receiving waters was derived and found to agree very well with measured salt pickup at one coal site. The minimum quantities of salts that will eventually be released from the spoils are estimated.

793. Mears, A.I., 1978, Flooding and sediment transport in a small alpine drainage basin in Colorado: Geology, v. 7, no. 1, p. 53-57.

794. Medine, A.J., 1983, Potential impacts of energy development upon water quality of Lake Powell and the Upper Colorado River, in Adams, V.D., and Lamarra, V.A., eds., Aquatic resources management of the Colorado River ecosystem, proceedings of the 1981 symposium, Las Vegas, Nevada, November 16-18, 1981: Ann Arbor, Mich., Ann Arbor Science Publishers, p. 399-424.

795. Meeker, R.I., and Reed, H.S., 1908, Surface water supply of Colorado River drainage above Yuma: U.S. Geological Survey Water-Supply Paper 211, 149 p.

796. Meeks, T.O., 1950, Reconnaissance of ground-water conditions in the Uncompahgre Valley, Colorado: Soil Conservation Service Regional Bulletin 112, Geologic Series 3, 27 p.

797. Mehls, S.F., 1982, Valley of opportunity--A history of west-central Colorado (cultural resources series): Bureau of Land Management Report BLM-CO-PT-83-0004-8100, 362 p. [Available from National Technical Information Service, Springfield, VA 22161 as NTIS Report PB-83 252 817.]

This document represents the latest history to be written for the western slope of Colorado. The three districts in this region of Colorado now have histories specifically for them. Oil and gas, coal, oil shale and other energy minerals, not to mention rights-of-ways, grazing programs, recreation projects and land-use planning, are all supported by histories such as this. 
798. Meister, A.D., and Nicol, K.J., 1975, A documentation of the National Water Assessment Model of regional agricultural production, land and water use, and environmental interaction (miscellaneous report): National Science Foundation Report NSF/RA/E-75/322, 236 p. [Available from National Technical Information Service, Springfield, VA 22161 as NTIS Report PB-292 797/8.]

This report documents agricultural programming models developed to meet the needs of the Water Resources Council in making the National Water Assessment. The models are the result of an attempt to simplify large-scale models for economy and cost considerations. Objectives to be accomplished by the models and the structure of the base model are described. The report also illustrates the required determinations used, summarizes the mathematical structure of the base model, details the source and nature of the data that go into the base model and its variants, and explains the nature and construction of each major sector. Sectors analyzed include land, water, soil loss, demand, crop, livestock, and transportation. A large amount of data used in the base model is included. Appendices present a Soils Conservation Service data questionnaire and streamflow data.

799. Mejia, N.M., Wohl, E.E., and Oaks, S.D., 1994, Geological hazards, vulnerability, and risk assessment using GIS model for Glenwood Springs, Colorado: Geomorphology, v. 10, no. 1-4, p. 331-354.

800. Melby, C.E., 1961, Resistivity method in groundwater exploration, city of Gunnison, Colorado: American Institute of Mining, Metallurgical, and Petroleum Engineers Transactions, v. 217, p. 328-332.

801. Messer, J.J., and Post, F.J., 1982, Impacts of Western coal, oil shale, and tar sands development on aquatic environmental quality--A technical information matrix [volume 1, introduction and instructions; volume 2, coal; volume 3, oil shale and tar sands]: Logan, Utah, Utah Water Research Laboratory Water Resources Planning Series 82-04, various pagination.

802. Meyers, C.J., 1966, Colorado River: Stanford Law Review, v. 19, p. 1-75.

803. Meyers, J.S., 1962, Evaporation from the 17 Western States: U.S. Geological Survey Professional Paper 272-D, $71 \mathrm{p}$.

804. Michaels, G.B., Flynn, T., Hill, J.J., and Schneck, D.J., 1982, Use of bacterial populations in assessing the effects of thermal effluents on water quality of streams: Gunnison, Colo., Western State College.

805. Middelburg, R.F., 1993, Colorado stream water quality, in Paulson, R.W., Chase, E.B., Williams, J.S., and Moody, D.W., comps., U.S. Geological Survey, National water summary 1990-91-Hydrologic events and stream water quality: U.S. Geological Survey Water-Supply Paper 2400, p. 197-206.

806. Miertschin, J.D., 1986, Alternative methods for estimation of phosphorus loadings: Journal of Environmental Engineering, v. 112, no. 6, p. 1153-1158.

Annual phosphorus loads for the Colorado River were estimated for the period 1968-1982, using several methods. The alternative methods displayed substantial 
variability in calculated loadings. The absence of a detailed test data base prevented an unequivocal selection of the most appropriate method. The load-flow relationship developed from the historical sampling data set was selected for use, because the method is based upon the complete set of observed phosphorus loadings, and it maximizes the use of the historic streamflow data.

807. Miller, C.A., 1971, Economics of water quality - salinity pollution - abridged bibliography: Fort Collins, Colo., Colorado Water Resources Research Institute Information Series IS 2.

808. Miller, J.B., Wegner, D.L., and Bruemmer, D.R., 1983, Salinity and phosphorus routing through the Colorado River/reservoir system, in Adams, V.D., and Lamarra, V.A., eds., Aquatic resources management of the Colorado River ecosystem, proceedings of the 1981 symposium, Las Vegas, Nevada, November 16-18, 1981: Ann Arbor, Mich., Ann Arbor Science Publishers, p., $19-41$.

809. Miller, J.F., Frederick, R.H., and Tracey, R.J., 1973, Precipitation-frequency atlas of the Western United States, v. 3-Colorado, v. 6-Utah: U.S. Department of Commerce National Oceanic and Atmospheric Administration Atlas 2.

810. Miller, P.H., and Coale, B.V., 1969, Colorado National Monument, a fantastic landscape sculptured by erosion: Fruita, Colo., Colorado and Black Canyon of the Gunnison Nature Association, $73 \mathrm{p}$.

811. Miller, T., 1966, A history of the Gunnison Waterworks--1880-1906: Gunnison Colo., Western State College, Master's thesis, $68 \mathrm{p}$.

812. Miller, T.O., Weatherford, G.D., and Thorson, J.E., 1986, The salty Colorado: Washington, D.C. and Napa, Calif., Conservation Foundation and John Muir Institute, $102 \mathrm{p}$.

813. Miller, W.H., Tyus, H.M., and Carlson, C.A., eds., 1982, Fishes of the Upper Colorado system-Present and future: Bethesda, Md., Western Division of the American Fisheries Society, $131 \mathrm{p}$.

814. Milliken, J.G., Lohman, L.C., and Howe, C.W., 1981, Feasibility of financial incentives to reuse low quality waters in the Colorado River Basin: Bureau of Reclamation Report OWRT-C-80228R(8820) (1), $94 \mathrm{p}$. [Available from National Technical Information Service, Springfield, VA 22161 as NTIS Report PB-82 256694.1

The cost-effectiveness of selected financial incentives for encouraging reuse of low quality/saline water collected by the Bureau of Reclamation for electric power plant cooling is analyzed. Penalty costs to water users presently using saline waters for agricultural/domestic purposes and the potential economic benefits in salinity reduction are identified. Non-quantifiable salinity control benefits were identified as well in terms of existing/potential beneficial water uses in the 7 Colorado River Basin states and general amenity benefits. Reuse of saline water by an electric power utility could be a viable and cost-effective method of salinity control. 
815. Milliken, J.G., Lohman, L.C., Lyon, S.A., and Sherk, G.W., Jr., 1977, State and local management actions to reduce Colorado River salinity (final report): U.S. Environmental Protection Agency Report EPA/908/3-77/002, 371 p. [Available from National Technical Information Service, Springfield, VA 22161 as NTIS Report PB-283 134/5.]

This report identifies and provides analysis of state and local management actions which may be taken state-by-state to reduce salinity in the Colorado River. The analysis and evaluation procedures focus on management actions to reduce salinity and only on actions which may be taken within the scope of existing legislation. The management actions were discussed and amended on the basis of technical feasibility, cost, legality, effectiveness in salinity control, scope of applicability, and political and social implications. Of over thirty possible state and local management actions considered, twelve have been proposed for implementation in the Colorado River Basin.

816. Milliken, J.G., Lohman, L.C., Trumbly, A.S., and Roll, Lynne, 1979, Overcoming legal and institutional barriers to planned reuse of water in the Colorado River Basin: Bureau of Reclamation Report OWRT-R-0050(7816)(1), 215 p. [Available from National Technical Information Service, Springfield, VA 22161 as NTIS Report PB-297 270/1.]

Research was undertaken to identify and analyze the severity of the legal, institutional, political, and economic obstacles to planned water reuse in the Colorado River Basin, to analyze and assess methods or strategies that aid in overcoming these obstacles, and to develop conclusions on them for the promotion of greater planned reuse within the Basin. Nonagricultural reuse and consumptive reuse of low quality water are emphasized. Barriers to reuse found in interstate and state-specific water allocation law and in federal and state environmental laws were identified through legal research; comprehensive interviews with water management officials in the Basin and a document review identified the institutional and political obstacles; available literature was used to document societal positions on different types of water reuse; and the concerns of water reusers were obtained from interviews and documentation. Five case studies of various attempts to reuse water in the Basin were conducted to establish the interaction between reuse barriers and incentives.

817. Milliken, J.G., and Meev, H.E., 1969, Economic and social impact of recreation at reclamation reservoirs--An exploratory study of selected Colorado reservoir sites: Denver, Colo., Bureau of Reclamation, 214 p.

818. Min. Sci. Press, 1911, Colorado River discharges: Min. Sci. Press, v. 103, p. 799.

819. Min. Sci. Press, 1912, Drainage and flow of Colorado River: Min. Sci. Press, v. 105, p. 598.

820. Molles, M., 1980, The impacts of habitat alterations and introduced species on the native fishes of the Upper Colorado River Basin, in Spofford, W.O., Jr., Parker, A.L., and Kneese, A.V., eds., Energy development in the Southwest, problems of water, fish and wildlife in the Upper Colorado River Basin, volume 2: Washington, D.C., Resources for the Future, Research Paper R-18, p. 163-181. 
821. Moody, C.D., and Mueller, D.K., 1984, Water quality of the Colorado River system-Historical trends in concentration, load, and mass fraction of inorganic solutes: Bureau of Reclamation Report REC-ERC 84-9, 60 p.

822. Moore, C.V., Synder, J.H., and Sun, P., 1974, Effects of Colorado River water quality and supply on irrigated agriculture: Water Resources Research, v. 10, no. 2, p. 137-144.

823. Moran, R.E., and Wentz, D.A., 1974, Effects of metal-mine drainage on water quality in selected areas of Colorado, 1972-73: Denver, Colo., Colorado Water Conservation Board Colorado Water Resources Circular 25, 250 p.

824. Morel-Seytoux, H.J., 1972, Selection of test variable for minimal time detection of basin response to natural or induced changes (completion report July 1, 1969-June 30, 1972): Fort Collins, Colo., Colorado State University OWRR-A-022-COLO(2), 21 p. [Available from National Technical Information Service, Springfield, VA 22161 as NTIS Report PB-214 114/1.]

Classical statistical tests have been used to assess whether an apparent change in basin response is the result of nature's caprice or of man's deliberate action. Often the physical information about the variable tested has been neglected. As a result the tests used are not optimal. Detection tests which use both the physical and statistical information can be designed, and they will have a superior power to the standard tests. The test variable to be used is a linear combination of several physical and random variables with weight factors determined by a minimization procedure. The minimization is restricted by several equality constraints of a physical origin. When applied to the Colorado River Basin Pilot Project area, the power of the test, expressed in years needed for detection, is increased by a factor of two.

825. Morel-Seytoux, H.J., and Saheli, F., 1973, Test of runoff increase due to precipitation management for the Colorado River Basin Pilot Project: Journal of Applied Meteorology, v. 12, no. 2, p. 322-337.

826. Morris, D.P., and Lewis, W.M., Jr., 1992, Nutrient limitation of bacterioplankton growth in Lake Dillon, Colorado: Limnology and Oceanography, v. 37, no. 6, p. 1179-1192.

827. Morrison-Knudsen Engineers, Inc., 1985, Gunnison River icing study, summary report: Gunnison, Colo., Upper Gunnison River Water Conservancy District, 59 p.

828. Morrison-Knudsen Engineers, Inc., 1990, Determination of an upper limit design rainstorm for the Colorado River Basin above Hoover Dam: Denver, Colo., Morrison-Knudsen Engineers, Inc., 142 p. [Available from National Technical Information Service, Springfield, VA 22161 as NTIS Report PB-91 104 562/XAB.]

Storms over the Southern Intermountain Region were reviewed to determine the cause of large rainfall amounts for the May through October season. Rainfall amounts from the largest storms were analyzed using a Bureau of Reclamation mini-storm computer program to determine DAD (depth-area-duration) values. These DAD data formed the basis for the development of the magnitude of the ULRDS (Upper Limit Design Rain Storm) for the Colorado River Basin above Hoover Dam. For this Basin, rainfall magnitude is influenced by topography, and the ULDRS magnitude is required for each storm centering. Review of the data from storms indicated that one storm 
centered on the San Juan Mountains was characteristic for the basin above Glen Canyon Dam. A storm centering on the Pine and Cedar Mountains was characteristic of the basin between Hoover and Glen Canyon dams. The ULDRS magnitude was determined for these two locations with individual storm spatial and temporal distributions provided.

829. Mortensen, A.R., ed., 1960, The Colorado...River of the West: Utah Historical Quarterly, v. 28, no. 3, p. 194-324.

830. Morton, R.C.B., and Armstrong, E.L., 1972, Colorado River Water Quality Improvement Program: Washington, D.C., Bureau of Reclamation, 109 p. [Available from National Technical Information Service, Springfield, VA 22161 as NTIS Report PB-229 800/8.]

The report sets forth a plan of attack in the form of a comprehensive ten-year Water Quality Improvement Program. It identifies potential solutions, both short and long range. Investigations are scheduled for control of salinity at point sources, diffuse sources, and irrigation sources. These investigations have been structured and integrated with programs involving desalting, weather modification, geothermal resources, and basin-wide water resources management. The objective of the program is to maintain salinity concentrations at or below levels presently found on the main stem of the Colorado River.

831. Morton, R.C.B., and Stamm, G.G., 1975, Critical water problems facing the eleven Western States, Westside Study: Denver, Colo., Bureau of Reclamation, 457 p.

832. Mosier, E.L., Ludington, S.D., and Yeoman, R.A., 1980, Analyses of rocks and stream sediments from the Hunter-Fryingpan Wilderness Area and the Porphyry Mountain Wilderness Study Area, Pitkin County, Colorado: U.S. Geological Survey Open-File Report 80-880, 118 p.

833. Moss, M., 1981, Briney Colorado River still defies salty solutions: High Country News, v. 13, no. 20, p. 1.

834. Mueller, D.K., 1990, Analysis of water-quality data and sampling programs at selected sites in north-central Colorado: U.S. Geological Survey Water-Resources Investigations Report 90-4005, 79 p.

835. Mueller, D.K., and Liebermann, T.D., 1988, Extension of streamflow and dissolved-solids records at selected sites in the Colorado River Basin, Arizona, California, Colorado, Nevada, New Mexico, Utah, and Wyoming, 1940-83: U.S. Geological Survey Water-Resources Investigations Report 87-4203, $74 \mathrm{p}$.

836. Mueller, D.K., and Moody, C.D., 1984, Historical trends in concentration and load of major ions in the Colorado River system, in French, R.H., ed., Salinity in watercourses and reservoirs, proceedings of the 1983 international symposium on state-of-the-art control of salinity, Salt Lake City, Utah, July 13-15, 1983: Stoneham, Mass., Butterworth Publishers, p. 181-192.

837. Mueller, D.K., and Osen, L.L., 1988, Estimation of natural dissolved-solids discharge in the Upper Colorado River Basin, Western United States: U.S. Geological Survey Water-Resources Investigations Report 87-4069, $62 \mathrm{p}$. 
838. Muffler, J.P., ed., 1978, Assessment of geothermal resources of the United States--1978: U.S. Geological Survey Circular 790, 163 p.

839. Murphy, E.C., 1905, Spring floods in the Colorado River Basin, in Destructive floods in the United States in 1905: U.S. Geological Survey Water-Supply Paper 162, p. 38-51.

840. Murray, D.K., Chronic, J., DeVoto, R.F., and Madole, R.F., 1968, Index of graduate theses and dissertations on Colorado geology by in-State institutions, 1905 through 1967: The Mountain Geologist, v. 5, no. 2, p. 45-67.

841. Mustard, E.W., and Rector, C.D., 1979, Wetlands, irrigation and salinity control--Lower Gunnison River Basin, Colorado, in Swanson, G.A., ed., The mitigation symposium--A national workshop in mitigating losses of fish and wildlife habitats: U.S. Department of Agriculture, Forest Service General Technical Report RM-65, p. 310-317.

842. Nakamichi, H., and Morel-Seytoux, H.J., 1969, Suitability of the Upper Colorado River Basin for precipitation management: Fort Collins, Colo., Colorado State University Hydrol. Paper 36, $62 \mathrm{p}$.

843. Nannen, L.W., Keith, F., and West, R.E., 1975, An investigation of the technical and economic feasibility of using low temperature geothermal sources in Colorado: Boulder, Colo., University of Colorado.

844. Narayanan, Rangesan, and Franklin, D.P., 1982, Evaluation of water conservation techniques in the Upper Colorado River Basin (water resources planning series report): Bureau of Reclamation Report OWRT-B-185-UT(1), 50 p. [Available from National Technical Information Service, Springfield, VA 22161 as NTIS Report PB-83 175315.$]$

The Upper Colorado River Basin contains large deposits of oil shale, tar sands, crude oil, coal, and natural gas. Agriculture still accounts for 90 percent of the water depletions, but future development of these energy resources is expected to take increasing amounts of water. A mixed-integer programming model was used to maximize returns to land, water, and mineral resources. The results were used to assess the need for government-sponsored water conservation measures to supplement water saving techniques employed by the private sectors in response to increased water prices. The feasibilities of various water conservation measures were examined within a benefit-cost analysis framework.

845. Narayanan, Rangesan, Padungchai, Sumol, and Bishop, A.B., 1979, An economic evaluation of the salinity impacts from energy development--The case of the Upper Colorado River Basin: Bureau of Reclamation Report OWRT-B-141-Utah(1), 79 p. [Available from National Technical Information Service, Springfield, VA 22161 as N'TIS Report PB-80 159 932.]

To analyze the effect of potential energy development on water allocation and water quality in the Upper Colorado River Basin, a linear programming model is formulated. Using the model, changes in salinity are predicted. Further, least-cost strategies to maintain the established numeric salinity criteria through both structural and nonstructural alternatives are developed. The effectiveness of alternative control measures are examined within given institutional constraints. Based on cost-benefit analysis, optimal salinity levels over time are proposed. The economic feasibility of 
presently planned structural measures to reduce salinity is investigated and contrasted with nonstructural alternatives.

846. Nash, Linda, 1991, Implications of climatic change for streamflow and water supply in the Colorado Basin, in Managing water resources in the West under conditions of climate uncertainty, proceedings of a colloquium, Scottsdale, Arizona, November 14-16, 1990: Washington, D.C., National Academy Press, p. 158-176.

847. Nash, L.L., and Gleick, P.H., 1991, Sensitivity of streamflow in the Colorado Basin to climatic changes: Journal of Hydrology, v. 125, no. 3-4, p. 221-241.

Changes in regional temperature and precipitation expected to occur as a result of the accumulation of greenhouse gases may have significant impacts on water resources. We use a conceptual hydrologic model, developed and operated by the National Weather Service, to study the sensitivity of surface runoff in several sub-basins of the Colorado River to these changes. Increases in temperature of 2 degree $C$ decrease mean annual runoff by $4-12 \%$. A temperature increase of 4 degree $C$ decreases mean annual runoff by $9-21 \%$. Increases or decreases in annual precipitation of $10-20 \%$ result in corresponding changes in mean annual runoff of approximately 10-20\%. For the range of scenarios studied, these results suggest that runoff in the basin is somewhat more sensitive to changes in precipitation than to changes in temperature. Seasonal changes were also observed, with peak runoff shifting from June to April or May. Fall and winter flows generally increase, whereas spring and summer flows decrease in most of the scenarios studied. These changes are attributed to an increase of the ratio of rain to snow and to a higher snowline. Although these results suggest that streamflow in the Colorado Basin is less sensitive to climatic changes than previous statistical studies have indicated, the magnitude of possible changes is nonetheless sufficiently great to have significant environmental, economic, and political implications.

848. Nash, L.L., and Gleick, P.H., 1993, Colorado River Basin and climatic change--The sensitivity of streamflow and water supply to variations in temperature and precipitation:

U.S. Environmental Protection Agency Report EPA/230/R-93/009, 129 p. [Available from National Technical Information Service, Springfield, VA 22161 as NTIS Report PB-94 128 527.]

Growing international concern about the greenhouse effect has led to increased interest in the regional implications of changes in temperature and precipitation patterns for a wide range of societal and natural systems, including agriculture, sea level, biodiversity, and water resources. The accumulation of greenhouse gases in the atmosphere due to human activities are likely to have significant, though still poorly understood, impacts on water quality and availability. One method developed over the last several years for determining how regional water resources might be affected by climatic change is to develop scenarios of changes in temperature and precipitation and to use hydrologic simulation models to study the impacts of these scenarios on runoff and water supply. In the paper the authors present the results of a multi-year study of the sensitivity of the hydrology and water resources systems in the Colorado River Basin to plausible climatic changes. 
849. National Commission on Water Quality, 1976, Public Law 92-500 assessment regional impacts, technical volume: Washington, D.C., National Commission on Water Quality NCWQ-75/99, 725 p. [Available from National Technical Information Service, Springfield, VA 22161 as NTIS Report PB-252 099/7.]

Authors review economic, institutional and environmental impacts of the Federal Water Pollution Control Act Amendments of 1972 (PL 92-500) on eleven regions: Delaware River Basin, Merrimack/Nashua rivers, the Kanawha River, Lake Erie, the Ohio River Basin, The Yellowstone River Basin, Puget Sound/Lake Washington, San Francisco Bay/Central Valley, the Colorado River, Houston Ship Channel/Galveston Bay, and the Chattahoochie-Flint-Apalachicola River system. This document attempts to summarize the information gathered from eleven regional assessment studies, also available through the National Technical Information Service, which were prepared for the Commission by independent contractors.

850. National Park Service, 1979, Gunnison wild and scenic river study--Draft environmental statement: Washington, D.C., U.S. Department of the Interior National Park Service, 147 p.

851. National Park Service, 1983, Curecanti National Recreation Area summary of Gunnison Basin water quality: Gunnison, Colo., U.S. Department of the Interior National Park Service.

852. National Park Service, 1986, Curecanti National Recreation Area water quality report, 19831984: Fort Collins, Colo., U.S. Department of the Interior National Park Service and Colorado State University, $138 \mathrm{p}$.

853. National Park Service, 1986, Curecanti National Recreation Area water quality data report: Fort Collins, Colo., U.S. Department of the Interior National Park Service, Water Resources Division.

854. National Park Service and Colorado Water Conservation Board, 1979, Gunnison wild and scenic river study-Final environmental statement: Denver, Colo., U.S. Department of the Interior National Park Service, 116 p.

855. National Weather Service, 1994, Upper Colorado report--1994 water year in review: Salt Lake City, Utah, National Weather Service, 13 p. [Annual report.]

856. National Weather Service, 1995, Water supply outlook, Upper Colorado report, February 1995: Salt Lake City, Utah, National Weather Service, 16 p. [Issued monthly January through May.]

857. Natural Energy Resources Company, 1987, Rocky Point Pumped Storage Project, FERC hydropower license application, exhibit E--Environmental report--Report on water use and quality, report on fish, wildlife, and botanical resources: Natural Energy Resources Company, $113 \mathrm{p}$.

858. Nehring, R.B., 1979, Evaluation of instream flow methods and determination of water quantity needs for streams in the State of Colorado: Fort Collins, Colo., Colorado Division of Wildlife, $144 \mathrm{p}$.

859. Nehring, R.B., 1979, Stream fishery investigations--Job 1, Taylor River flow investigations: Montrose, Colo., Colorado Division of Wildlife, Federal Aid Project F-51-R, Res. Proposal, 23 p.

114 Bibliography, Indices, and Data Sources of Water-Related Studies, Upper Colorado River Basin, Colorado and Utah, 1872-1995 
860. Nehring, R.B., 1980, Stream fishery investigations--Job 1, Fish flow investigations; Job 3, Special regulations evaluation: Colorado Division of Wildlife, Federal Aid F-51-R-5, Job Progress Report, $161 \mathrm{p}$.

861. Nehring, R.B., 1986, Stream fisheries investigations--Job 1, Fish flow investigations; Job 6 , Colorado River aquatic invertebrates investigations: Fort Collins, Colo., Colorado Division of Wildlife, Federal Aid Project F-51-R, Job Progress Report, Job 1, p. 1-15, Job 6, p. 41-48.

862. Nehring, R.B., 1987, Stream fisheries investigations--Job 3, Special regulations evaluation: Fort Collins, Colo., Colorado Division of Wildlife, Federal Aid Project F-51-R, Job Final Report, $118 \mathrm{p}$.

863. Nehring, R.B., 1993, Stream fisheries investigations-Job 1, Fish flow investigations: Fort Collins, Colo., Colorado Division of Wildlife, Federal Aid Project F-51, Job Final Report, 1 p.

864. Nehring, R.B., [n.d.], Analysis of brown trout population dynamics in the Taylor River from 1974 through 1980 in relation to winter flow conditions: Montrose, Colo., Colorado Division of Wildlife.

865. Nehring, R.B., and Anderson, R.M., 1981, Stream fisheries investigations--Job 1, Taylor River flow investigations; Job 2, Special regulations evaluations: Fort Collins, Colo., Colorado Division of Wildlife, Federal Aid Project F-51-R-6, Job Progress Report, 160 p.

866. Nehring, R.B., and Anderson, R.M., 1982, Stream fishery investigations--Job 1, Taylor River flow investigations; Job 3, Special regulations evaluation: Colorado Division of Wildlife, Federal Aid Project F-51-R-7, Job Progress Report, 185 p.

867. Nehring, R.B., and Anderson, R.M., 1983, Stream fisheries investigations: Fort Collins, Colo., Colorado Division of Wildlife.

868. Nehring, R.B., and Anderson, R.M., 1993, Determination of population-limiting critical salmonid habitats in Colorado streams using the Physical Habitat Simulation System: Rivers, v. 4 , no. 1, p. 1-19.

869. Nehring, R.B., and Miller, D.D., 1987, The influence of spring discharge levels on rainbow and brown trout recruitment and survival, Black Canyon of the Gunnison River, Colorado, as determined by IFIM/PHABSIM models: Western Association of Fish and Wildlife Agencies and Western Division of the American Fisheries Society, Proceedings, v. 67, p. 388-397.

870. Nehring, R.B., and Thompson, K.G., 1994, Stream fisheries investigations--Job 2, Special regulations evaluation; Job 3, Native salmonid stream fisheries investigations: Fort Collins, Colo., Colorado Division of Wildlife, Federal Aid Project F-51, Job Progress Report, Job 2, p. 9-25, Job 3, p. 26-32.

871. Nelson, S.M., and Flickinger, S.A., 1992, Salinity tolerance of Colorado squawfish, Ptychocheilus lucius (Pisces: Cyprinidae): Hydrobiologia, v. 246, no. 2, p. 165. 
872. Nelson, W., Horak, G., Hale, A., Parkhurst, Z., Lewis, M., Wagaman, D., Hoban, E., and Colt, J., 1976, Assessment of effects of altered stream flow characteristics on fish and wildlife, part A, Rocky Mountains and Pacific Northwest, Rocky Mountain case studies: U.S. Fish and Wildlife Service Report FWS/OBS-76-30.

873. Nelson, W.C., 1955, Green Mountain Reservoir studies: Denver, Colo., Colorado Department of Game and Fish, 214 p.

874. Nelson, W.C., 1972, Comparative limnology of Colorado Big Thompson Project reservoirs and lakes: Colorado Department of Game, Fish, and Parks Res. Rev. v. 7, p. 1-2.

875. Nelson, W.C., Horak, G., Lewis, M., and Colt, J., 1976, Assessment of effects of altered stream flow characteristics on fish and wildlife, part A, Rocky Mountains and Pacific Northwest, final report: U.S. Fish and Wildlife Service Report FWS/OBS-76-29, 119 p.

876. Nelson, W.C., Horak, M.L., and Colt, J., 1976, Assessment of altered stream flow characteristics on fish and wildlife, part A, Rocky Mountains and Pacific Northwest, executive summary: U.S. Fish and Wildlife Service Report FWS/OBS-76-28, 14 p.

877. Newell, F.H., 1903, Colorado reclamation: U.S. Reclamation Service Annual Report 1, p. 129-160.

878. Newlin, J.T., and Ward, R.C., 1974, An analysis of non-point source pollution in the Rocky Mountain-Praire Region, preliminary draft, part 1: U.S. Environmental Protection Agency Report CSU-CES-31-4040-2050, 433 p. [Available from National Technical Information Service, Springfield, VA 22161 as NTIS Report PB-255 273.]

The purpose of this report is to provide a description of the identified non-point sources of pollution within the six-state area of Colorado, Utah, Wyoming, Montana, North Dakota, and South Dakota which comprises Region VIII under the jurisdiction of the Environmental Protection Agency's Denver office. The areas of concern which have been investigated and reported upon include: irrigation return flows, range and watershed management, logging and forestry, rural-domestic wastes, livestock and waste disposal, pesticides and fertilizers, land disposal, and surface and groundwater problems.

879. Newton, W.A., 1964, A geologic evaluation of the proposed Ruedi Dam and Reservoir, Eagle County, Colorado: Mountain Geologist, v. 1, no. 2, p. 73-77.

880. Nichols, S.R., Skogerboe, G.V., and Ward, R.C., 1972, Water quality management decisions in Colorado: Fort Collins, Colo., Colorado Water Resources Research Institute Completion Report CR 38.

881. Nimmo, D.W.R., Link, D., Parrish, L.P., Rodriguez, G.J., Wuerthele, W., and Davies, P.H., 1989, Comparison of on-site and laboratory toxicity tests; derivation of site-specific criteria for unionized ammonia in a Colorado transitional stream: Environmental Toxicology and Chemistry, v. 8 , no. 12 , p. 1177-1189. 
882. Nordlund, B.D., and Liebermann, T.D., 1990, Estimates of dissolved solids and major dissolved constituents for 70 streamflow-gaging stations in the Upper Colorado River Basin, Arizona, Colorado, New Mexico, Utah, and Wyoming: U.S. Geological Survey Open-File Report 87-547, $441 \mathrm{p}$.

883. Norris, J.M., 1986, Application of the Precipitation-Runoff Modeling System to small basins in the Parachute Creek Basin, Colorado: U.S. Geological Survey Water-Resources Investigations Report 86-4155, 38 p.

884. Norris, J.M., 1987, Surface water-quality characteristics in the upper North Fork Gunnison River Basin, Colorado: U.S. Geological Survey Water-Resources Investigations Report 86-4152, 42 p.

885. Norris, J.M., and Maura, W.S., 1985, Water-quality data for streams in the upper North Fork of the Gunnison River, Colorado: U.S. Geological Survey Open-File Report 85-190, 122 p.

886. Northwest Colorado Council of Governments, 1989, Northwest Colorado Council of Governments' areawide water quality management plan for Eagle, Grand, Jackson, Pitkin, Routt, and Summit counties, Colorado [1988 plan update]; volume I, water quality program development; volume II, policy plan: Frisco, Colo., Northwest Colorado Council of Governments,

887. Norton, S.A., Hess, C.T., Blake, G.M., Morrison, M.L., and Baron, J., 1985, Excess unsupported $210 \mathrm{~Pb}$ in lake sediment from Rocky Mountain lakes--A groundwater effect: Canadian Journal of Fisheries and Aquatic Sciences, v. 42, p. 1249-1254.

888. NUS Corporation, 1981, Biological/water quality evaluation related to Colorado's stream classification: Denver, Colo., NUS Corporation Report 3925, 19 p.

889. Nygren, W.E., 1935, An outline of the general geology and physiography of the Grand Valley district (Mesa County), Colorado: Boulder, Colo., University of Colorado, Master's thesis.

890. Odell, J.W., Coffin, D.L., and Langford, R.H., 1964, Water resources, in Mineral and water resources of Colorado [Report for the use of U.S. Senate Committee on Interior and Insular Affairs, U.S. Congress, 88th, 2d session]: U.S. Geological Survey Communication Print, p. 233-283.

891. Office of the State Engineer, 1995, Stream flow data for Colorado: Denver, Colo., Colorado Division of Water Resources. [Published annually.]

892. Office of the State Engineer, 1995, Water diversion records and reservoir storage summaries: Denver, Colo., Colorado Division of Water Resources. [Published annually from approximately 1900 through the present.]

893. Ohmart, R.D., Deason, W.O., and Burke, C., 1977, A riparian case history; the Colorado River: U.S. Department of Agriculture, Forest Service General Technical Report Rm-43, p. 35-47.

894. Olive, J.R., 1953, A bibliography of the limnology and fishery biology of Colorado: Denver, Colo., Colorado Department of Game and Fish, 37 p.

895. Olson, R.L., 1962, The Colorado River Compact: Cambridge, Mass., Harvard University, Ph.D. dissertation, $527 \mathrm{p}$. 
896. Osmundson, B.C., 1992, Inorganic elements detected in sediments and aquatic biota from the Uncompahgre River and Ridgway Reservoir, Colorado: U.S. Fish and Wildlife Service Contaminant Report R6/303J/92, 42 p.

897. Osmundson, D.B., and Kaeding, L.R., 1989, Studies of Colorado squaw fish and razorback sucker use of the '15-mile reach' of the Upper Colorado River as part of conservation measures for the Green Mountain and Ruedi Reservoir water sales, final report: Grand Junction, Colo., U.S. Fish and Wildlife Service, 85 p.

898. Osmundson, D.B., and Kaeding, L.R., 1991, Recommendations for flows in the '15-mile reach' during October-June for maintenance and enhancement of endangered fish populations in the Upper Colorado River, final report: Grand Junction, Colo., U.S. Fish and Wildlife Service, 94 p. [Available from National Technical Information Service, Springfield, VA 22161 as NTIS Report PB-92 106 061/XAB.]

This is the second of two reports that collectively provide recommendations for yearround flows in the 15-mile reach of the Upper Colorado River. The conclusions and recommendations presented in the report are based on the best available biological information. A study is currently being conducted that will help refine these recommendations. The study will relate habitat quality, quantity, and diversity to incremental river discharge levels. A third report will be prepared in 1992 that will include the results of the new study, summarize recommendations made in the two preceding reports, and include appropriate modifications to the flow recommendations based on the new information. Future studies in the Upper Colorado subbasin will no doubt provide additional information and improve our understanding of the relationships between flow and the well-being of endangered fish populations. As a result, there will be a continuing effort to refine the recommendations for flows needed to recover these species.

899. Pahren, H.R., and Town, W.W., 1960, Waste disposal aspects of potential pulp mills in western Colorado: Cincinnati, Ohio, Robert A. Taft Sanitary Engineering Center SEC-TR-W60-5, 23 p. [Available from National Technical Information Service, Springfield, VA 22161 as NTIS Report PB-216 383.1

The Rocky Mountain Forest and Range Experiment Station of the U.S. Forest Service requested the U.S. Public Health Service to evaluate the water pollution aspects of several potential pulp mill sites as a part of a comprehensive study which the Forest Service is making of the opportunity for pulp mill development in western Colorado. This report presents an appraisal of the situation based on present available data.

900. Parker, R.S., 1991, Developing an index of hydrologic drought for the Gunnison River Basin, Colorado, in Kirby, W.H., and Weiyan, Tan, comps., Proceedings of the United States--People's Republic of China bilateral symposium on droughts and arid-region hydrology, Tucson, Arizona, September 16-20, 1991: U.S. Geological Survey Open-File Report 91-244, p. 175-182.

901. Parker, R.S., and Battaglin, W.A., 1993, Assessment of effects of potential climate change on the hydrology of the Gunnison River Basin, in Kelmelis, J.A., and Snow, K.M., eds., Proceedings of the U.S. Geological Survey global change research forum, Herndon, Virginia, March 18-20,1991: U.S. Geological Survey Circular 1086, p. 104. 
902. Parker, R.S., Kuhn, Gerhard, Hay, L., and Elliott, J.G., 1992, Effects of potential climate change on the hydrology and the maintenance of channel morphology in the Gunnison River Basin, Colorado: Workshop on the effects of global climate change on the hydrology and water resources at a catchment scale, Tsukuba-shi, Japan, February 3-6, 1992, Proceedings, p. 399-410.

903. Patt, R.O., Adams, D.B., and Collins, D.L., 1982, Hydrologic data from Naval Oil Shale Reserves, Parachute Creek Basin, northwestern Colorado, 1975-79: U.S. Geological Survey Open-File Report 82-696, 134 p.

904. Patterson, J.L., and Somers, W.P., 1966, Magnitude and frequency of floods in the United States, part 9, Colorado River Basin: U.S. Geological Survey Water-Supply Paper 1683, 475 p.

905. Paulson, L.J., 1983, Scientific perspectives on integrated aquatic resources management of the Colorado River, in Adams, V.D., and Lamarra, V.A., eds., Aquatic resources management of the Colorado River ecosystem, proceedings of the 1981 symposium, Las Vegas, Nevada, November 16-18, 1981: Ann Arbor, Mich., Ann Arbor Science Publishers, p. 685-688.

906. Peale, A.C., 1886, Lists and analyses of the mineral springs of the United States (a preliminary study): U.S. Geological Survey Bulletin 32, 188 p.

907. Pearce, F., 1987, Banishing the salt of the Earth: New Scientist, v. 114, no. 1564, p. 53-56.

908. Pearl, R.H., 1971, Bibliography of hydrogeologic reports in Colorado: Denver, Colo., Colorado Geological Survey Bulletin 33, 39 p.

909. Pearl, R.H., 1972, Geothermal resources of Colorado: Denver, Colo., Colorado Geological Survey Special Publication 2, 54 p.

910. Pearl, R.H., 1974, Geology of ground water resources in Colorado--An introduction: Denver, Colo., Colorado Geological Survey Special Publication 4, 47 p.

911. Pearl, R.H., ed., 1974, Proceedings of a symposium on geothermal energy and Colorado: Denver, Colo., Colorado Geological Survey Bulletin 35, 102 p.

912. Pearl, R.H., 1979, Colorado's hydrothermal resource base--An assessment: Denver, Colo., Colorado Geological Survey Resource Series 6, 144 p.

913. Pearl, R.H., 1980, Geothermal resources of Colorado: Denver, Colo., Colorado Geological Survey Map Series 14, 1 sheet, scale 1:500,000.

914. Pearl, R.H., 1980, Ground-water resources of Colorado, in Kent, H.C., and Porter, K.W., eds., Colorado geology: Denver, Colo., Rocky Mountain Association of Geologists, p. 243-245.

915. Pearl, R.H., 1981, Hydrothermal resources of western Colorado, in Epis, R.C., and Callender, J.F., eds., Western Slope, Colorado--Western Colorado and eastern Utah, New Mexico Geological Society, thirty-second field conference, Oct. 8-10, 1981: New Mexico Geological Society Guidebook 32, p. 333-335. 
916. Pearl, R.H., and Coe, B.A., 1979, Geothermal energy development in Colorado, appendix 7 of regional operations research program for development of geothermal energy in the Southwest United States, final technical report, June 1977 to August, 1978: Idaho Falls, Idaho, U.S. Department of Energy.

917. Pearl, R.H., and Coe, B.A., 1980, Potential for geothermal energy development in Colorado, in Kent, H.C., and Porter, K.W., eds., Colorado geology: Denver, Colo., Rocky Mountain Association of Geologists, p. 247-249.

918. Pearl, R.H., Zacharakis, T.G., Repplier, F.N., and McCarthy, K.P., 1981, Bibliography of geothermal reports in Colorado: Denver, Colo., Colorado Geological Survey Bulletin 44, 24 p.

919. Pearl, R.H., Zacharakis, T.G., and Ringrose, C.D., 1982, Geothermal resource assessment of Hot Sulphur Springs, Colorado: Denver, Colo., Colorado Geological Survey Resource Series 23, 23 p.

920. Peckarsky, B., 1983, Report to the Sierra Club--Water quality of the upper East River and Cooper Creek, Gunnison County, Colorado: Ithaca, N.Y., Cornell University, 6 p.

921. Peckarsky, B.L., and Penton, M.A., 1990, Effects of enclosures on stream microhabitat and invertebrate community structure: Journal North American Benthological Society, v. 9, p. $249-261$.

922. Pennak, R.W., 1950, A limnological reconnaissance of Grand Mesa, Colorado: University of Colorado Biol. Serv., v. 1, p. 15-23.

923. Pennak, R.W., 1969, Colorado semidrainage mountain lakes: Limnology and Oceanography, v. 14, no. 5 , p. $720-725$.

924. Pennak, R.W., and Van Gerpen, E.D., 1947, Bottom fauna production and physical nature of the substrate in a Colorado trout stream: Ecology, v. 28, no. 1, p. 42-48.

925. Perry, T.W., 1989, Tectonic inference and computer simulation in stream longitudinal profile evolution, Unaweep Canyon and vicinity, Colorado and Utah [abs.]: Geological Society of America Abstracts with Programs, v. 21, no. 6, p. 269.

926. Peterson, D.F., and Crawford, A.B., eds., 1978, Values and choices in the development of the Colorado River Basin: Tucson, Ariz., University of Arizona Press, 337 p.

927. Petsch, H.E., Jr., 1979, Streamflow statistical summaries for Colorado streams through September 30, 1975, volume 2, Colorado River Basin above Gunnison River: U.S. Geological Survey Open-File Report 79-1060, 354 p.

928. Petsch, H.E., Jr., 1983, Streamflow statistical summaries for Colorado streams through September 30, 1975, volume 3, Colorado River Basin from Gunnison River to San Juan River: U.S. Geological Survey Open-File Report 83-693, 439 p.

929. Petsch, H.E., Jr., 1986, Colorado surface-water resources, in Moody, D.W., Chase, E.B., and Aronson, D.A., comps., U.S. Geological Survey, National water summary 1985--Hydrologic events and surface-water resources: U.S. Geological Survey Water-Supply Paper 2300, p. 167-174.

120 Bibliography, Indices, and Data Sources of Water-Related Studies, Upper Colorado River Basin, Colorado and Utah, 1872-1995 
930. Pettus, D., 1974, Inventory and impact analysis of fishes, Piceance Creek Basin, Rio Blanco and Garfield Counties, Colorado: Boulder, Colo., Thorne Ecological Institute Ross-25, 13 p.

931. Pfeffer, F.M., 1974, Pollutional problems and research needs for the oil shale industry: Ada, Okla., Robert S. Kerr Environmental Research Laboratory EPA-600/2-74-067, 44 p.

[Available from National Technical Information Service, Springfield, VA 22161 as NTIS Report PB-236 608/6SL.]

The oil shale resources and surface stream drainage within the Green River Formation of Colorado, Utah, and Wyoming are presented briefly. Oil shale retorting in place is summarized. The subject of major concern, stabilization of spent shale residue, is covered in detail. Other subjects of environmental concern discussed are retort waste water, process water from shale-oil upgrading, dewatering, mineral recovery, and contamination of groundwater by radioactivity.

932. Phoenix, D.A., 1961, Proposed classification of ground-water provinces, hydrologic units, and chemical types of ground water in the Upper Colorado River Basin, in Short papers in the geologic and hydrologic sciences: U.S. Geological Survey Professional Paper 424-C, p. C125-C127.

933. Pimentel, R., and Bulkley, R.V., 1983, Concentrations of total dissolved solids preferred or avoided by endangered Colorado River fishes: American Fisheries Society Transactions, v. 112, no. 5, p. 595-600.

Juveniles (age 0-1) of three endangered Colorado River fishes were subjected to a gradient of total dissolved solids (TDS) to determine the concentrations that they preferred or avoided. Preferred and avoided TDS concentrations, respectively, for juveniles of each species were: Colorado squawfish, Ptychocheilus lucius, 560-1, $1,150 \mathrm{mg} /$ liter and greater than $4,400 \mathrm{mg}$ /liter humpback chub, Gila cypha, $1,000-2,500 \mathrm{mg} /$ liter and greater than $5,100 \mathrm{mg} /$ liter and bonytail, Gila elegans, $4,100-4,700 \mathrm{mg} /$ liter and less than $560 \mathrm{mg} / \mathrm{liter}$ or greater than $6,600 \mathrm{mg} /$ liter. Colorado squawfish and humpback chub selected TDS concentrations that were similar to those in waters they now inhabit, but bonytail selected concentrations four times higher.

934. Pings, W.B., 1967, Water pollution in Colorado--Part I: Mineral Ind. Bull., v. 10, no. 6, p. 1-13.

935. Pings, W.B., 1968, Water pollution in Colorado--Part II: Mineral Ind. Bull., v. 11, no. 1, p. 1-20.

936. Pitlick, J., 1994, Coarse sediment transport and the maintenance of fish habitat in the Upper Colorado River, in Shen, H.W., Su, S.T., and Wen, F., eds., Hydraulic Engineering '94, Proceedings of the 1994 conference, Buffalo, N.Y., August 1-5, 1994: New York, N.Y., American Society of Civil Engineers, p. 855-859.

937. Pitlick, J., 1994, Relation between peak flows, precipitation, and physiography for five mountainous regions in the Western USA: Journal of Hydrology, v. 158, no. 3-4, p. 219-240. 
938. Pitney, K.A., 1990, USDA Colorado River Salinity Control Program, in Riggins, R.E., ed., Watershed planning and analysis in action, proceedings of the symposium sponsored by the Committee on Watershed Management of the Irrigation and Drainage Division of the American Society of Civil Engineers in conjunction with the ASCE Irrigation and Drainage Conference in Durango, Colorado, July 9-11, 1990: New York, N.Y., American Society of Civil Engineers, p. $265-272$.

Approximately 37 percent of the salt contribution in the Colorado River can be attributed to irrigation activities in the river basin. The United States Department of Agriculture (USDA), in cooperation with farmers, has initiated an extensive salinity control program to reduce salt loading to the Colorado River. Early efforts were directed to a successful onfarm irrigation water management program in the WelltonMohawk area. Also, the Soil Conservation Service (SCS) completed salinity control studies and prepared reports for various irrigated areas. The USDA salinity control program is being implemented in four areas, other areas are awaiting implementation funds, and planning is underway in two additional areas. A variety of salinity control practices are being applied by farmers with assistance from USDA.

940. Plumlee, G.S., Smith, K.S., and Ficklin, W.H., 1994, Geoenvironmental models of mineral deposits, and geology-based mineral-environmental assessments of public lands: U.S. Geological Survey Open-File Report 94-203, 7 p.

941. Plumlee, G.S., Smith, K.S., Ficklin, W.H., and Briggs, P.H., 1992, Geological and geochemical controls on the composition of mine drainages and natural drainages in mineralized areas, in Kharaka, Y.K., and Maest, A.S., eds., Water-rock interaction, proceedings of the 7th international symposium on water-rock interaction-WRI-7, Park City, Utah, July 13-18, 1992: Rotterdam, The Netherlands, Balkema, p. 419-422.

942. Plumlee, G.S., Smith, K.S., Ficklin, W.H., Briggs, P.H., and McHugh, J.B., 1993, Empirical studies of diverse mine drainages in Colorado--Implications for the prediction of mine-drainage chemistry: Mined land reclamation symposium, Billings, Montana, 1993, Proceedings, v. 1, p. 176-186.

943. Ponce, S.L., and Hawkins, R.H., 1976, Prediction of salt pickup by overland flow in the Upper Colorado River Basin [abs.]: EOS, American Geophysical Union Transactions, v. 57, no. 12, p. 913.

944. Powell, G.C., 1958, Evaluation of the effects of a power dam water release pattern upon the downstream fishery: Fort Collins, Colo., Colorado State University, Master's thesis, 149 p.

945. Pratt, H.P., 1938, Ecology of the trout of the Gunnison River: Boulder, Colo., University of Colorado, Ph.D. dissertation, 197 p.

946. PRC Engineering, 1986, Grand Mesa water supply study: PRC Engineering [?]. [Prepared for Colorado Water Conservation Board, Grand Mesa Water Conservancy District and the Colorado River Water Conservation Board.]

947. Presser, T.S., Evans, W.C., White, L.D., and Barnes, Ivan, 1981, Chemical and isotopic compositions of selected soda and hot spring waters and gases, Colorado: U.S. Geological Survey Open-File Report 81-684, 9 p.

122 Bibllography, Indices, and Data Sources of Water-Related Studies, Upper Colorado River Basin, Colorado and Utah, 1872-1995 
948. Prestel, M., 1992, Annual report on the biological assessment of the Eagle River Superfund Site, Eagle County, Colorado: Colorado Division of Wildlife, 27 p.

949. Price, D., and Arnow, T., 1974, Summary appraisals of the Nation's ground-water resources, Upper Colorado region: U.S. Geological Survey Professional Paper 813-C, 40 p.

950. Price, D., and Waddell, K.M., 1973, Selected hydrologic data in the Upper Colorado River Basin: U.S. Geological Survey Hydrologic Investigations Atlas HA-477, 2 sheets, scale 1:2,500,000.

951. Price, J.B., 1986, Application of a mixing cell model to describe contaminant transport--An example of appropriate technology, in Abt, S.R., Nelson, J.D., Shepherd, T.A., Wardell, R.E., and Van Zyl, D., eds., proceedings of the 8th annual symposium on geotechnical and geohydrological aspects of waste management, Fort Collins, Colorado, February 5-7, 1986: Rotterdam, The Netherlands, Balkema, p. 197-203.

952. Pucherelli, M.J., Clark, R.C., and Williams, R.D., 1990, 1989 Upper Basin interagency standardized monitoring program--Green and Colorado rivers habitat mapping using airborne video: U.S. Fish and Wildlife Service, Colorado River Recovery Implementation Program Reports.

953. Pugsley, E.B., Cheng, C.Y., Updergraff, D.M., and Ross, L.W., 1971, Removal of heavy metals from mine drainage in Colorado by precipitation: Chemical Engineering Progress, Symposium Series, v. 67 , no. 107 , p. $75-89$.

954. Quartarone, F., 1993, Historical accounts of Upper [Colorado] Basin endangered fish: Denver, Colo., Colorado Division of Wildlife.

955. Radosevich, G.E., Skogerboe, G.V., McWhorter, D.B., and Walker, W.R., 1977, Salinity management alternatives for oil shale water supplies: Natural Resources Journal, v. 17, no. 3, p. $461-475$.

956. Rapp, J.R., Doyle, W.W., and Chase, E.B., 1968, Index to ground water stations: U.S. Geological Survey Office of Water Data Coordination, Information on Water Data Catalog, $104 \mathrm{p}$.

957. Rasmussen, J.L., 1970, Atmospheric water balance and hydrology of the Upper Colorado River Basin: Water Resources Research, v. 6, no. 1, p. 62-76.

958. Rasmussen, J.L., 1972, Cloud seeding interpreted through atmospheric water balance: American Society of Civil Engineers, Journal of the Irrigation and Drainage Division, v. 98, no. IR4, p. 585-592.

959. Reagents of the University of Colorado, 1992, Effects of climate change in the Colorado alpine--Ecosystem response to altered snowpack and rainfall regimes, a proposal to the National Science Foundation: Boulder, Colo., University of Colorado, 94 p.

960. Reclamation Era, 1974, Colorado River salinity, new solutions to an old problem: Reclamation Era, v. 60, no. 4, p. 1.

961. Rector, C.D., 1979, Lower Gunnison River Basin wetland inventory and evaluation: Boulder, Colo., University of Colorado, Master's thesis, $71 \mathrm{p}$. 
962. Rector, C.D., 1979, Lower Gunnison River Basin wetland inventory and evaluation: Denver, Colo., U.S. Department of Agriculture, Soil Conservation Service, 90 p.

963. Rector, C.D., Mustard, E.W., and Windell, J.T., 1978, Preliminary report, lower Gunnison River Basin wetland inventory and evaluation: Denver, Colo., U.S. Department of Agriculture, Soil Conservation Service, $65 \mathrm{p}$.

964. Reed, P.B., 1988, Wetlands plants in Colorado: U.S. Fish and Wildlife Service.

965. Reiser, D.W., Vitter, M.W., and Todd, J., 1982, Reclamation of Colorado streams impacted by acid mine drainage, proceedings: Colorado-Wyoming American Fishery Society, v. 17, p. $120-132$.

966. Reisner, M., 1986, Cadillac Desert--The American West and its disappearing water: New York, N.Y., Viking, 582 p.

967. Repplier, F.N., and Fargo, R.L., 1981, Geothermal gradient map of Colorado: Denver, Colo., Colorado Geological Survey Map Series 20, scale 1:1,000,000.

968. Repplier, F.N., Healy, F.C., Collins, D.B., and Longmire, P.A., 1981, Atlas of ground water quality in Colorado: Denver, Colo., Colorado Geological Survey Map Series 16, 7 sheets, scale 1:50,000.

969. Repplier, F.N., Relf, M.M., and Columbia, R.K., 1981, Groundwater temperature map of Colorado: Denver, Colo., Colorado Geological Survey Map Series 21, scale 1:1,000,000.

970. Reynolds, S.E., 1972, The water quality problem on the Colorado River: Natural Resources Journal, v. 12 , no. 4 , p. 480-486.

971. Rhinehart, C.G., 1975, Minimum streamflows and lake levels in Colorado: Fort Collins, Colo., Colorado Water Resources Research Institute Information Series 18, 54 p. plus appendices A-H.

972. Rhodes, J.B., Smith, H.L., Jr., and Ogg, J.E., 1986, Isolation of non-O1 Vibrio cholerae serovars from surface waters in western Colorado: Applied and Environmental Microbiology, v. 51, no. 6, p. 1216-1219.

973. Richards, R., and Ferchau, H.A., 1978, Buttes Gas and Oil Iron Hill-Powderhorn study, 1977, v. 2: Gunnison, Colo., Western State College.

974. Richter, B.D., Kircher, J.E., Remmers, M.A., and Forst, B.A., 1974, Summary of basin and streamflow characteristics for selected basins in western Colorado and adjacent States: U.S. Geological Survey Open-File Report 84-137, 266 p.

975. Riehl, H., and Elsberry, R.L., 1964, Precipitation episodes in the Upper Colorado River Basin: Pure and Applied Geophysics, v. 57, p. 213-220.

976. Riggle, F.R., and Kysar, L.N., 1985, Salinity control in the Grand Valley of Colorado, in Perspectives on nonpoint source pollution, proceedings of a national conference, Kansas City, Missouri, May 19-22, 1985: Washington, D.C., U.S. Environmental Protection Agency, p. 359-361. 
977. Riley, P.E., 1950, Geology of an area along the Colorado River, T. 3 S., R. 85 W., Eagle County, Colorado: Boulder, Colo., University of Colorado, Master's thesis.

978. Riley, R.G., Garland, T.R., Shiosaki, K., Mann, D.C., and Wildung, R.E., 1981, Alkylpyridines in surface water, groundwater, and subsoils of a drainage located adjacent to an oil shale facility: Environmental Science and Technology, v. 15, no. 6, p. 697-701.

979. Ringe, A.C., 1973, Oil shale--A bibliography with abstracts: Springfield, Va., National Technical Information Service, $59 \mathrm{p}$.

980. Rittmaster, R.L., and Mueller, D.K., 1984, Solute loading mechanisms in the Colorado River Basin [abs.]: EOS, American Geophysical Union Transactions, v. 65, no. 16, p. 212.

981. Ritzman, H.R., and Oriel, S.S., 1955, Guidebook to the geology of northwest Colorado: Denver, Colo., Intermountain Association of Petroleum Geologists and Rocky Mountain Association of Geologists, $185 \mathrm{p}$.

982. Riverside Technology, Inc., 1985, Reservoir monitoring report for the Denver Water Department systemwide/site-specific EIS: Fort Collins, Colo., Riverside Technology, Inc.

983. Riverside Technology, Inc., 1985, Special water quality monitoring report for the Denver Water Department systemwide/site-specific EIS: Fort Collins, Colo., Riverside Technology, Inc.

984. Riverside Technology, Inc., 1986, Thermal analysis report in support of the systemwide environmental impact statement, Denver Water Department: Denver, Colo., Denver Water Department.

985. Rizvi, S.S.A., 1967, Investigation of water supply depletion in the Upper Colorado River Basin: Boulder, Colo., University of Colorado, Ph.D. dissertation, 177 p.

986. Rizvi, S.S.A., 1968, Investigation of water supply depletion in the Upper Colorado River Basin [abs.]: Dissertation Abstracts, v. 28, no. 9, p. 3701B, 196.

987. Robbins, D.W., 1976, Quantification of instream flow needs by law in Colorado, in Orsborn, J.F., and Allman, C.H., eds., Proceedings of a symposium and speciality conference on instream flow needs, volume 1: Washington, D.C., American Fisheries Society, p. 184-203.

988. Robbins, W.W., 1910, Climatology and vegetation in Colorado: Botanical Gazette, v. 49, p. 256-280.

989. Roberts, Jennifer, ed., 1993, Showdown on the Colorado River, Colorado water workshop, proceedings: Fort Collins, Colo., Colorado Water Resources Research Institute Information Series IS 75.

990. Rocky Mountain Oil and Gas Association, 1975, Summary of industry oil shale environmental studies and selected bibliography of oil shale environmental references: Rocky Mountain Oil and Gas Association, $31 \mathrm{p}$.

991. Rold, J.W., 1974, Geothermal energy and Colorado--An introduction, in Proceedings of a symposium on geothermal energy and Colorado: Denver, Colo., Colorado Geological Survey Bulletin 35, p. 1-9. 
992. Romberger, S.B., 1980, Metallic mineral resources of Colorado, in Colorado geology: Denver, Colo., Rocky Mountain Association of Geologists, p. 225-236.

993. Rosenlund, B.D., and Stevens, D.R., 1990, Fisheries and aquatic management, Rocky Mountain National Park, 1989-1990 [annual report]: Golden, Colo., U.S. Fish and Wildlife Service and National Park Service, 188 p. [Also available is the annual report for 1987 published in 1988.]

994. Ross, L.W., 1973, Removal of heavy metals from mine drainage by precipitation: Denver, Colo., University of Denver EPA-14040-FZC, 71 p. [Available from National Technical Information Service, Springfield, VA 22161 as NTIS Report PB-228 584.]

Heavy metals in mine drainage waters of the Rocky Mountains can be removed by a two-stage process consisting of (1) neutralization followed by (2) sulfide treatment. The first stage removes ferric and aluminum hydroxides, and the second (sulfide) stage precipitates the heavy metals that are most objectionable as pollutants, and that are of possible interest for economic recovery. The two-stage process has been demonstrated in the laboratory and in a field experiment.

995. Rothfield, L.B., 1975, Water and energy requirements for an oil shale industry, in Conference on water requirements for Lower Colorado River Basin energy needs, May 8-9, 1975, University of Arizona, Tucson: Tucson, Ariz., University of Arizona, p. 81-105.

996. Rought, B.G., 1984, Southwestern salinity situation--The Rockies to the Mississippi, in French, R.H., ed., Salinity in watercourses and reservoirs, proceedings of the 1983 international symposium on the state-of-the-art control of salinity, Salt Lake City, Utah, July 13-15, 1983: Stoneham, Mass., Butterworth Publishers, p. 115-124.

997. Royer, L.E., Hunt, J.D., and Crawford, A.B., 1978, Recreation (Colorado Basin), in Peterson, D.F., and Crawford, A.B., eds., Values and choices in the development of the Colorado River Basin: Tucson, Ariz., University of Arizona Press, p. 173-194.

The Colorado Basin provides an amenities region with unique physiographic and climatic diversity. Because of its diversity, it cannot serve as a case study for other areas, but a study of the conditions affecting recreation do show that it is very space costly and that recreational activities are largely determined by present-day choice of recreational pleasures.

998. Ruddy, B.C., 1987, Sediment discharge in Muddy Creek and the effect of sedimentation rate on the proposed Wolford Mountain Reservoir near Kremmling, Colorado: U.S. Geological Survey Water-Resources Investigations 87-4011, $22 \mathrm{p}$.

999. Ruddy, B.C., 1989, Use of a hydraulic potentiomanometer to determine ground-water gradients in a wetland, Colorado, in Fisk, D.W., ed., Proceedings of the symposium on wetlands-Concerns and successes, Tampa, Florida, September 17-22, 1989: Bethesda, Md., American Water Resources Association Technical Publication Series TPS-89-3, p. 175-183. [Also published in 1989 in Proceedings of the symposium on headwaters hydrology, American Water Resources Association, Bethesda, Md., p. 675-683.] 
1000. Ruddy, B.C., and Williams, R.S., Jr., 1991, Hydrologic relations between streamflow and subalpine wetlands in Grand County, Colorado: U.S. Geological Survey Water-Resources Investigations Report 90-4129, 53 p.

1001. Ruiter, D.E., and Bishop, M.B., 1984, Surface water hydrology, water quality, and aquatic life of the Colorado-Utah oil shale region--A data summary (final report): U.S. Environmental Protection Agency Report 908/3-84/002, 891 p. [Available from National Technical Information Service, Springfield, VA 22161 as NTIS Report PB-85 169 225.]

This document provides a summary of the available surface water hydrology, water quality, and aquatic life data for the oil shale region of Colorado and Utah. The report is intended to provide a reference document for regulators, developers, and others who may be involved in the study of aquatic ecosystems within the region. More than 160 documents were reviewed during the compilation of this report, and those that contained data are summarized. Two sections of the report are concerned with data deficiencies and reference stream recommendations. These sections should be useful in the design and implementation of future studies within the region.

1002. Rumberg, C.B., Gery, B.H., and Butcher, K., 1978, Gunnison County stream water quality study: U.S. Environmental Protection Agency Report EPA-908/3-78-001, 85 p. [Available from National Technical Information Service, Springfield, VA 22161 as NTIS Report PB-295 429.]

This research was done to determine the water quality of all major streams in Gunnison County during Calendar Year 1977. A large number of biological, chemical, and physical water quality parameters were assessed. Also included in the study was review of existing literature and other pertinent water quality data, integrating that information with the conclusions from other 1977 research.

1003. Runnells, D.D., Brown, D., and Lindberg, R., 1974, Investigation of enrichment of molybdenum in the environment through comparative study of stream drainages, central Colorado, in Proceedings of the 1st annual NSF trace contaminants conference, August 8-10, 1973: Oak Ridge, Tenn., U.S. Atomic Energy Commission Technical Information Center, p. 599-614.

1004. Rushing, D.E., 1963, The analysis of effluents and environmental samples from uranium mills and of biological samples for uranium, radium, and polonium (supplementary materials): U.S Public Health Service Report SM-41-44, 74 p. [Available from National Technical Information Service, Springfield, VA 22161 as NTIS Report PB-260 010/4.]

Five supplementary papers are presented: (1) determination of uranium, a fluorimetric method; (2) the determination of radium-225, a simplified emanation technique; (3) the determination of radium-226 in silicates, a rapid isolation method; (4) determination of radium-226, preparation and analysis of special types of samples; and (5) determination of polonium-210. Tables are included with each report. 
1005. Ryan, T.P., and Sieh, D., 1993, Integrating hydrologic models, geographic information systems, and multiple databases; a data centered approach, in Burton, J.S., comp., Proceedings of the Federal Interagency workshop on hydrologic modeling demands for the 90's: U.S. Geological Survey Water-Resources Investigations 93-4018, p. 3.26-3.34.

Data centered architecture offers a framework for the development of a decision support system for water resource management. Hydrologic models, geographic information systems (GIS), databases, and analysis software can be effectively integrated using a data centered approach. Such a data centered system has been implemented by the Bureau of Reclamation for water system operation, planning, and management in the Upper Colorado River Basin. The GIS interface is an effective tool for monitoring the current conditions of the system. The GIS display provides an easy method to view current telemetry at gage sites in a selected subbasin. The integration of the Colorado River database with the River Simulation System (RSS) and the Modular Hydrologic Modeling System (MHMS) applications simplifies the preparation of model input data for simulations. The integrated plotting programs and statistical functionality in MHMS and the connection to S Plus (a tool for statistical data analysis, time series plotting and visualization of data) in RSS simplify post processing and analysis of model output as well.

1006. Sawyer, J.W., Jr., Brown, F.L., and Abbey, D., 1980, Energy development scenarios for the Four Corners states and the Upper Colorado River Basin, in Spofford, W.O., Jr., Parker, A.L., and Kneese, A.V., eds., Energy development in the Southwest, problems of water, fish and wildlife in the Upper Colorado River Basin, volume 1: Washington, D.C., Resources for the Future, Research Paper R-18, p. 79-152.

1007. Schleusener, R.A., and Crow, L.W., 1961, Analysis of precipitation data in the Upper Colorado River Basin (technical paper): Fort Collins, Colo., Colorado State University CER61-52, 68 p. [Available from National Technical Information Service, Springfield, VA 22161 as NTIS Report PB-213 999/6.]

A sample of daily precipitation and temperature data from 30 weather observing locations in or near the Upper Colorado River Basin have been placed on cards and partially analyzed by computer techniques. The sample represents a total of 1660 station years, and analytical conclusions give a good representation of the climatic ranges for this area. Frequency of precipitation at multiple time intervals for each location are presented. Major storms having a recurrence less than once per year have been found to contribute significantly to runoff in the Upper Colorado River. Preliminary techniques for adjusting actual precipitation to more closely relate to runoff are presented and further refinements are anticipated. Variations in moisture sources have been studied.

1008. Schmidt, K.H., 1985, Regional variation of mechanical and chemical denudation, Upper Colorado River Basin, USA: Earth Surfaces Processes and Landforms, v. 10, no. 5, p. 497-508.

The variation of mechanical and chemical denudation is investigated using discharge and sediment yield data from the Upper Colorado River System. Annual precipitation ranges from approximately $150 \mathrm{~mm}$ to $1500 \mathrm{~mm}$. Mean specific yield ranges from $0.21 / \mathrm{s} \mathrm{km}^{2}$ (6 $\mathrm{mm} \mathrm{p}$ a) to $151 / \mathrm{s} \mathrm{km}^{2}$ ( $475 \mathrm{~mm} \mathrm{p} \mathrm{a).} \mathrm{The} \mathrm{hydrological-geomorphological}$ system adjusts itself to these varying climatic conditions; in some areas, however, the 
effects of lithology or land use seem to override the climatic controls. It is demonstrated that the increase in the absolute and particularly the relative amount of suspended sediment is closely related to a decrease in annual runoff and to an increase in the importance of high magnitude/low frequency events. Events of moderate magnitude and frequency, which in more humid areas transport most of the dissolved load, seldom occur. Mechanical and chemical denudation are of equal importance at a runoff of about $300 \mathrm{~mm}$ per year.

1009. Schneider, E.J., 1975, Surficial geology of the Grand Junction-Fruita area, Mesa County, Colorado: Fort Collins, Colo., Colorado State University, Master's thesis, $141 \mathrm{p}$.

1010. Schulman, E., 1945, History of precipitation and runoff in the Colorado Basin as indicated by tree-rings: Cambridge, Mass., Harvard University, Ph.D. dissertation.

1011. Schumm, S.A., 1975, Evaluation of the storage mechanisms of diffuse sources of salinity in the Upper Colorado River Basin: Sci. Technol. Aerosp. Rep., v. 13, no. 3, p. 38.

1012. Schumm, S.A., Gellis, A., and Watson, C.C., 1987, Variability of sediment and salt loads in the Upper Colorado River Basin--Significance for conservation and management, phase 1:

National Science Foundation ISI-87096, 112 p. [Available from National Technical Information Service, Springfield, VA 22161 as NTIS Report PB90-220740.]

The objective of the research was to investigate both sediment and salt loads in the Upper Colorado River Basin and to determine the reason for any change. Analysis of sediment and salt load data shows that, although affected by hydrologic variability, both sediment ( 6 stations) and salt (14 stations) loads have decreased since about 1935. Aerial reconnaissance and field surveys show that the incised channels (arroyos) that once supplied large quantities of sediment to the Colorado River during the period starting about 1880 have widened. In addition, new flood plains have formed. Decreased sediment production from upstream tributaries and from channel side walls and sediment storage in the flood plains all appear to be the reason for the significant regional reduction of sediment loads. Reduced erosion and sediment may account for the reduced salt loads.

1013. Schumm, S.A., and Lusby, G.C., 1963, Seasonal variation of infiltration capacity and runoff on hillslopes in western Colorado: Journal of Geophysical Research, v. 68, no. 11, p. 3655-3666.

1014. Schuster, R.J., 1989, Colorado River Simulation System, in Ports, M.A., ed., Hydraulic engineering: National conference on hydraulic engineering, New Orleans, Louisiana, 1989, Proceedings, p. 473-478.

The Colorado River Simulation System (CRSS) is a comprehensive computer tool designed to assist water resource managers in long-range planning and management of the Colorado River Basin. The CRSS is used to address the many 'what if' questions that arise from proposed basin development or proposed changes in the methods of operating the river. The CRSS simulates riverflows, water deliveries, water shortages, reservoir operations, water quality, and hydroelectric power production.

1015. Schwochow, S.D., 1975, Selected references on Colorado mineral resources: Colorado Geological Survey Open-File Report 75-2, 59 p. 
1016. Schwochow, S.D., 1981, Inventory of nonmetallic mining and processing operations in Colorado: Denver, Colo., Colorado Geological Survey Map Series 17, 39 p. plus 17 maps, scale $1: 250,000$.

1017. Scott, R.C., and Voegeli, P.T., Sr., 1961, Radiochemical analyses of ground and surface water in Colorado, 1954-1961: Denver, Colo., Colorado Water Conservation Board Basic-Data Report 7, $27 \mathrm{p}$.

1018. Seethaler, K., 1978, Life history and ecology of the Colorado squawfish (Ptychocheilus lucius) in the Upper Colorado River Basin: Logan, Utah, Utah State University, Master's thesis, 155 p.

1019. Sersland, H.N., 1977, Fish and wildlife mitigation on U.S. Bureau of Reclamation projects, Upper Colorado region--Past and future: Annual conference Western Association Game, Fish Comm., v. 57, Proceedings, p. 257-262.

1020. Shafer, B.A., Jensen, D.T., and Jones, K.C., 1984, Analysis of 1983 snowmelt runoff production in the Upper Colorado River Basin: Western Snow Conference, Sun Valley, Idaho, 1984, Proceedings, $11 \mathrm{p}$.

1021. Shen, H.W., Laronne, J.B., Enck, E.D., Sunday, G., and Tanji, K.K., 1981, Role of sediment in nonpoint source salt loading within the Upper Colorado River Basin: Bureau of Reclamation Report OWRT-B-137-COLO(1), 234 p. [Available from National Technical Information Service, Springfield, VA 22161 as NTIS Report PB-82 236 654. Also published through Colorado State University as Colorado Water Resources Research Institute Completion Report CR 107, 213 p.]

The role of sediment in diffuse-source salt loading in the Upper Colorado River Basin was investigated. The results proved that entrainment and transport of sediment by overland and channelized flow are crucial factors affecting the salinity of runoff from diffuse source areas. Increased concentration of transported sediment increases the availability of soluble minerals; further transported sediment may continue dissolving due to kinetic disequilibrium and/or when mixed with Colorado River water.

1022. Sheridan, D., 1983, The Colorado; an engineering wonder without enough water: Smithsonian, v. 13 , no. 11 , p. $44-55$.

1023. Showen, C.R., and Williams, O.O., 1973, Index to water-quality data available from the U.S. Geological Survey in machine-readable form to December 31, 1972, Central Region: U.S. Geological Survey Water-Resources Investigations 73-22, 954 p.

This report lists water-quality stations operated by the Geological Survey in the central U.S. for which data are available in machine-readable form. The data are the results of analyses of water samples and indicate the chemical and physical characteristics of surface water and groundwater. The stations are listed according to station number within each state. The water-quality data are identified by 5-digit parameter codes and are grouped into 21 parameter categories. The analytical results for all samples in any one year are then grouped within the parameter categories. The report lists the available retrieval options, the machine-readable output options, user charges, and how to obtain the data.

130 Bibliography, Indices, and Data Sources of Water-Related Studies, Upper Colorado River Basin, Colorado and Utah, 1872-1995 
1024. Shown, L.M., 1970, Evaluation of a method for estimating sediment yield, in Geological Survey Research 1970: U.S. Geological Survey Professional Paper 700-B, p. 245-249.

1025. Siemer, E.G., and Heermann, D.F., 1970, Climatological data for Gunnison, Colorado and the Mountain Meadow Research Ranch: Fort Collins, Colo., Colorado State University Experiment Station General Series Bulletin 908, 16 p.

1026. Sievers, G.D., 1949, The bacteriology and relative hardness of certain waters of the Gunnison watershed, Gunnison, Colorado: Gunnison, Colo., Western State College, Master's thesis.

1027. Simons, D.B., I.i, R.M., Schall, J.D., Kimzey, J.R., and Anzia, T.L., 1982, Development of smallplot rainfall simulation devices to study effects of livestock grazing on infiltration rates, runoff, sediment yields and salinity of surface runoff from Mancos Shale-derived soil (final report): Fort Collins, Colo., Simons, Li and Associates, 322 p. [Available from National Technical Information Service, Springfield, VA 22161 as NTIS Report PB-85 238 442/XAB.]

The salinity problem is the most serious water quality problem in the Colorado River system. The average salt load of the Colorado River at Hoover Dam has been estimated to be more than 10 million tons annually, based on data for the period 1942-1961 (Bureau of Land Management, 1978). Further downstream at Imperial Dam the salinity level in terms of concentration averaged $865 \mathrm{mg} / \mathrm{L}$ in 1971, with a projected increase to $1340 \mathrm{mg} / \mathrm{L}$ by the year 2000. In the text of Public Law 96-375, annual economic damages resulting from salinity are estimated in 1979 dollars to be $\$ 343,000$ per $\mathrm{mg} / \mathrm{L}$ increase at Imperial Dam. Clearly economic considerations, as well as water quality standards and international concerns over salinity of the water flowing into Mexico, require consideration of all possible methods to reduce salt loading in the Colorado River system.

1028. Skinner, J.W., 1994, The history, evolution, and practical aspects of instream flows in Colorado --A prior appropriation State, in Marston, R.A., and Hasfurther, V.R., eds., Proceedings, annual summer symposium of the American Water Resources Association, effects of human-induced changes on hydrologic systems, Jackson Hole, Wyoming, June 26-29, 1994: Bethesda, Md., American Water Resources Association Technical Publication Series TPS-94-3, p. 395-402.

1029. Skinner, M.M., 1963, Colorado ground-water levels, spring 1963: Fort Collins, Colo., Colorado State University Experiment Station CER63MMS21, 11 p.

1030. Skinner, M.M., and Thomas, J.L., 1964, Colorado ground-water levels, spring 1964: Fort Collins, Colo., Colorado State University Experiment Station CER64MMS9, 74 p.

1031. Skogerboe, G.V., 1982, Colorado River development, in Water and energy development in an arid environment--The Colorado River Basin: Water Supply and Management, v. 6, no.1-2, p. 29-61.

1032. Skogerboe; G.V., 1982, Development issues in the Colorado River Basin, in Water and energy development in an arid environment--The Colorado River Basin: Water Supply and Management, v. 6, no. 1-2, p. 3-10. 
1033. Skogerboe, G.V., 1982, The physical environment of the Colorado River Basin, in Water and energy development in an arid environment--The Colorado River Basin: Water Supply and Management, v. 6, no.1-2, p. 11-27.

1035. Skogerboe, G.V., Barrett, J.W.H., Treat, B.J., and McWhorter, D.B., 1979, Potential effects of irrigation practices on crop yields in Grand Valley: U.S. Environmental Protection Agency Report EPA/-S-800687, 208 p. [Available from National Technical Information Service, Springfield, VA 22161 as NTIS Report PB-80 101 553.]

An analysis has been undertaken to determine the economically optimal seasonal depth of irrigation water to apply under conditions of both limited and plentiful water supply. The objective was to determine if general guidelines having practical utility could be postulated for all water supply situations. An extensive range of literature pertaining to the relationship between crop yield and the amount of water applied has been reviewed and differences suggested by various authors have been resolved. In addition, 32 plots of corn and 10 plots of wheat were grown under different irrigation regimes in the Grand Valley of Colorado to supplement the results of other researchers and to provide further insight into effects of stress at different stages of plant growth.

1036. Skogerboe, G.V., Huszar, P.C., Radosevich, G.E., Trock, W.L., and Vlachos, E.C., 1978, Socioeconomic and institutional factors in irrigation return flow quality control, volume IV, Grand Valley case study (final report): U.S. Environmental Protection Agency Report EPA/600/2-78174D, 151 p. [Available from National Technical Information Service, Springfield, VA 22161 as NTIS Report PB-287 448/5.]

The Grand Valley was used as a case study area for developing an effective process for implementing technical and institutional solutions to the problem of pollution from irrigation return flows. This area is the most significant agricultural salt source in the Upper Colorado River Basin. The primary source of salinity is from the extremely saline aquifers overlying the marine deposited Mancos Shale formation. Subsurface irrigation return flows resulting from conveyance seepage losses and over irrigation of croplands dissolve salts from this formation before returning to the Colorado River. The most cost-effective technologies for reducing the salt load are a combination of lateral lining and on-farm improvements. Farmer participation in such a program is very important. Implementation will result in excess water being available for selling, renting, or leasing to water users upstream from Grand Valley.

1037. Skogerboe, G.V., and McWhorter, D.B., 1979, Irrigation practices and return flow salinity in Grand Valley (final report): U.S. Environmental Protection Agency Report EPA/600/2-79/148, 220 p. [Available from National Technical Information Service, Springfield, VA 22161 as NTIS Report PB-80 103 609.]

This study was undertaken to evaluate the relationships between leachate volume and chemical quality. A numerical model of soil moisture and salt transport was used. Field data were collected on 63 research plots located in the Grand Valley, Colorado. From the calibration of the moisture flow model using infiltration data, water content profiles and storage change data, it was concluded that soil moisture flow could be adequately modeled for the Grand Valley. From comparisons of field and simulated data used in evaluating the soil chemistry model, it was concluded that total dissolved solid concentrations were adequately modeled but that individual ionic species 
concentrations were not. The TDS profile calculated at the beginning and end of the growing season show the salt concentration in the profile below the root zone to be relatively constant.

1038. Skogerboe, G.V., and Radosevich, G.E., 1982, Future water development policies, in Water and energy development in an arid environment--The Colorado River Basin: Water Supply and Management, v. 6, no. 1-2, p. 221-232.

1039. Skogerboe, G.V., and Walker, W.R., 1971, Preconstruction evaluation of the Grand Valley Salinity Control Demonstration Project: Fort Collins, Colo., Colorado State University AER 70-71 GVS-WRW5.

1040. Skogerboe, G.V., and Walker, W.R., 1972, Evaluation of canal lining for salinity control in Grand Valley (environmental protection technology series): Ada, Okla., Robert S. Kerr Water Research Center EPA-R2-72-047, 214 p. [Available from National Technical Information Service, Springfield, VA 22161 as NTIS Report PB-214 113/3.]

The report discusses a project to evaluate the salinity control effectiveness of canal and lateral linings for reduction of seepage losses in to the ground water. Grand Valley in the Upper Colorado River Basin was used as a model. A detailed evaluation of the necessary hydrologic and salinity parameters in the principal demonstration area was made. A hydro-salinity model has been prepared, which has allowed the itemizing of the various segments of the dual flow system into water and salt budgets for the periods prior to and immediately after the construction of the linings. In addition, the results were employed to derive some generalized valley-wide water and salt budgets. The salinity control benefits exceeded the costs of the canal lining program.

1041. Skogerboe, G.V., and Walker, W.R., 1973, Salt pickup from agricultural lands in the Grand Valley of Colorado: Journal of Environmental Quality, v. 2, no. 3, p. 377-382.

1042. Skogerboe, G.V., and Walker, W.R., 1975, Salinity policy for Colorado River Basin: American Society of Civil Engineers, Journal of the Hydraulics Division, v. 101, no. HY8, p. 1067-1075.

1043. Skogerboe, G.V., and Walker, W.R., 1977, Research and demonstration approach to development of appropriate salinity control technologies for Grand Valley, in Proceedings of national conference on irrigation return flow quality management, Fort Collins, Colorado, May 16-19, 1977: Fort Collins, Colo., Colorado State University, p. 353-359.

1044. Skogerboe, G.V., Walker, W.R., Bennett, R.S., Ayars, J.E., and Taylor, J.H., 1974, Evaluation of drainage for salinity control in Grand Valley (environmental protection technology series): U.S. Environmental Protection Agency Report EPA-660/2-74-084, 111 p. [ $\Lambda$ vailable from National Technical Information Service, Springfield, VA 22161 as NTIS Report PB-240 213/9.]

Irrigation return flows in the Grand Valley of Western Colorado contribute to the serious salinity problems in the Colorado River Basin by carrying large salt loads resulting from contact with local saline soils and aquifers. Since the valley is one of the more significant salt sources, it is therefore a logical area for evaluation of the effectiveness of various salinity control measures. The study has emphasized two on-farm control alternatives, namely, irrigation scheduling and field drainage. The 
contents of the report consider the latter measure. Three farms were extensively studied during the 1972 and 1973 irrigation seasons to identify drainage needs and the effect field relief drainage would have on reducing salinity in the return flows.

1045. Skogerboe, G.V., Walker, W.R., and Evans, R.G., 1982, Salinity control measures for Grand Valley, in Water and energy development in an arid environment--The Colorado River Basin: Water Supply and Management, v. 6, no. 1-2, p. 129-167.

1046. Skogerboe, G.V., Walker, W.R., Evans, R.G., and Smith, S.W., 1976, Evaluating improved irrigation water management technologies for reducing salt pickup from Grand Valley: International Salinity Conference, Texas Tech University, Lubbock, Texas, August 16-20, 1976, Proceedings, p. 506-536.

1047. Skogerboe, G.V., Walker, W.R., Taylor, J.H., and Bennett, R.S., 1974, Evaluation of irrigation scheduling for salinity control in Grand Valley (environmental protection technology series): U.S. Environmental Protection Agency Report EPA-600/2-74-052, 96 p. [Available from National Technical Information Service, Springfield, VA 22161 as NTIS Report PB-235 633/5.]

Although the results of the study indicate that existing programs for irrigation scheduling in the Grand Valley to control salinity are having only a marginal effect, the potential for 'scientific' irrigation scheduling has been well established. Also, irrigation scheduling should not be taken individually as a salinity control measure because its effectiveness is not exclusive of the operation of the total irrigation system. Thus, irrigation scheduling is a necessary, but not sufficient, tool for achieving irrigation efficiencies.

1048. Smith, Z.A., 1989, Groundwater in the West: San Diego, Calif., Academic Press, Inc., 308 p.

In large sections of the West, groundwater is the only dependable source of water available. For the 19 western States (AK, AZ, CA, CO, HA, ID, KS, MT, NB, NV, NM, ND, OK, OR, SD, TX, Ut, WA, WY), 38\% of the water consumed comes from the ground. This book examines the use, management, laws, and politics of groundwater in the West. The introductory chapter provides an overview of important groundwater management and policy issues that regularly present themselves. Each of the subsequent chapters is devoted to one of the 19 States, and the chapters are, for the most part, similarly organized. After a brief description of the water environment in the State, and the presentation of a map showing the major groundwater regions in the State, the chapters provide a summary of groundwater problems in the State, and a summary of groundwater law, administration, and regulations. The chapters conclude with a section summarizing groundwater politics (where appropriate) and an evaluation of future potential groundwater management problems. A glossary and an extensive bibliography follow the concluding chapter.

1049. Smuin, D.R., 1990, Geology and hydrology of the shallow alluvial aquifer, West Sharrard Gulch, Colorado: The Mountain Geologist, v. 27, no. 4, p. 107-118. 
1050. Snyder, W.D., and Miller, G.C., 1992, Changes in riparian vegetation along the Colorado River and Rio Grande, Colorado: Great Basin Naturalist, v. 52, no. 4, p. 357-363.

Changes in vegetation including area occupied, canopy cover, and maturity class of cottonwoods (Populus spp.) within lower-elevation zones of the Colorado River and Rio Grande in Colorado were monitored over 25- and 37-year intervals, respectively, using photo-interpretative methods. Estimated loss of cottonwoods along the Colorado River was $2 \mathrm{ha} / \mathrm{km}(-17.5 \%)$, and remaining stands had become more open and older. Cottonwoods along the Rio Grande increased $1.6 \mathrm{ha} / \mathrm{km}(9.3 \%)$ with minor canopy cover and maturity class changes. Area occupied by shrubs and river channel changed little along the Colorado River and farmland increased along the Rio Grande. Wildlife habitats along the Colorado deteriorated much more rapidly than those along the Rio Grande during monitored intervals.

1051. Soil Conservation Service, 1975, Erosion, sediment, and related salt problems and treatment opportunities: Golden, Colo., U.S. Department of Agriculture, Soil Conservation Service, 152 p.

This report is intended as a regional and state assessment of erosion, sediment, and related salt problems showing (1) sediment yield rates which are occurring, (2) data related to erosion, sediment, and salt loading, (3) critical source areas affecting water quality, (4) types, cost, and location of treatment potential, (5) impacts of erosion control and sediment and salt reductions on land and water quality, water development and management. State evaluations include Arizona, Colorado, Idaho, Montana, Nevada, New Mexico, Oregon, Utah, Washington, and Wyoming. This report was written for the Western United States Water Plan (Westside Study).

1052. Soil Conservation Service, 1975, General soil map of Colorado: U.S. Department of Agriculture, Soil Conservation Service.

1053. Soil Conservation Service, 1975, On-farm salinity control investigations for the Grand Valley area, State of Colorado: Denver, Colo., U.S. Department of Agriculture, Soil Conservation Service, 19 p. plus 3 attachments.

1054. Soil Conservation Service, 1977, On-farm program for salinity control--Final report of the Grand Valley Salinity Study: U.S. Department of Agriculture, Soil Conservation Service.

1055. Soil Conservation Service, 1985, Flood plain management study--Parachute Creek in the vicinity of Parachute, Colorado, and Roan Creek in the vicinity of De Beque, Colorado: Denver, Colo., U.S. Department of Agriculture, Soil Conservation Service, 28 p.

1056. Soil Conservation Service, [various dates], General soil map: U.S. Department of Agriculture, Soil Conservation Service. [General soil map produced by the Soil Conservation Service for each county in Colorado.]

1057. Soil Conservation Service, [various dates], Soil survey by county and state: U.S. Department of Agriculture, Soil Conservation Service, various pagination. 
1058. Sotiros, R., 1970, Salinity Control Project proposal for Dotsero and Glenwood Springs, Eagle and Garfield Counties, Colorado: Boulder, Colo., U.S. Federal Water Pollution Control Administration, 96 p. [Available from National Technical Information Service, Springfield, VA 22161 as NTIS Report PB-257 326/9.]

The report discusses the stratigraphy, flow discharge, water quality, and project proposal.

1059. Spahr, N.E., and Ruddy, B.C., 1983, Reservoir evaporation in central Colorado: U.S. Geological Survey Water-Resources Investigations Report 83-4103, 232 p.

1060. Spofford, W.O., Jr., 1980, Potential impacts of energy development on streamflows in the Upper Colorado River Basin, in Spofford, W.O., Jr., Parker, A.L., and Kneese, A.V., eds., Energy development in the Southwest, problems of water, fish and wildlife in the Upper Colorado River Basin, volume 1: Washington, D.C., Resources for the Future, Research Paper R-18, p. 351-429.

1061. Spofford, W.O., Jr., Parker, A.L., and Kneese, A.V., 1980, Energy development in the Southwest, problems of water, fish and wildlife in the Upper Colorado River Basin, volumes 1 and 2: Washington, D.C., Resources for the Future, Research Paper R-18, 523 p. and 551 p.

1062. Stamm, G.G., and Bessler, M.B., 1977, Future role of desalting for water-quality improvement; Colorado River Basin, United States of America: Desalination, v. 20, no. 1-3, p. 1-18.

1063. Stanford, J.A., 1989, Flow alteration and ecosystem stability in the Gunnison River, Colorado-A perspective: Polson, Mont., University of Montana, $8 \mathrm{p}$.

1064. Stanford, J.A., 1993, Instream flows to assist the recovery of endangered fishes of the Upper Colorado River Basin--Review and synthesis of ecological information, issues, methods and rationale; final report to U.S. Fish and Wildlife Service, Denver, Colorado: Polson, Mont., Flathead Lake Biological Station Report 130-93.

1065. Stanford, J.A., and Ward, J.V., 1983, The effects of mainstream dams on physiochemistry of the Gunnison River, Colorado, in Adams, V.D., and Lamarra, V.A., eds., Aquatic resources management of the Colorado River ecosystem, proceedings of the 1981 symposium, Las Vegas, Nevada, November 16-18, 1981: Ann Arbor, Mich., Ann Arbor Science Publishers, p. 43-56.

1066. Stanford, J.A., and Ward, J.V., 1985, The effects of regulation on the limnology of the Gunnison River--A North American case history, in Lillehammer, A., and Saltveit, S., eds., Regulated rivers: Oslo, Norway, Universitetsforlaget As., p. 467-480.

1067. Stanford, J.A., and Ward, J.V., 1986, Fish of the Colorado system, in Davies, B.R., and Walker, K.F., eds., The ecology of river systems: Dordrecht, The Netherlands, Dr W. Junk Publishers, p. 385-402.

1068. Stanford, J.A., and Ward, J.V., 1986, Reservoirs of the Colorado system, in Davies, B.R., and Walker, K.F., eds., The ecology of river systems: Dordrecht, The Netherlands, Dr W. Junk Publishers, p. 375-383. 
1069. Staub, M.W., 1992, Passive mine drainage treatment in a bioreactor; the significance of flow, area, and residence time: Golden, Colo., Colorado School of Mines, Master's thesis, 133 p.

1070. Stearns, N.D., Stearns, H.T., and Waring, G.A., 1937, Thermal springs in the United States: U.S. Geological Survey Water-Supply Paper 679-B, 131 p.

1071. Steele, T.D., 1985, Harmonic analyses of stream temperatures in the Upper Colorado River Basin: U.S. Geological Survey Water-Resources Investigations 84-4290, 51 p.

1072. Steele, T.D., and Kunkel, J.R., 1986, A comparison of individual project-related water-quality impacts of processed-shale disposal, northwestern Colorado, in Gary, J.H., ed.: Nineteenth oil shale symposium, Golden, Colorado, April 21-22, 1986, Proceedings, p. 217-228.

1073. Steele, T.D., Weaver, R.M., and Mott, D.E., 1991, Temporal and spatial patterns in trace-metal concentrations of a mountain stream in west-central Colorado, USA, in Peters, N.E., and Walling, D.E., eds., Sediment and stream water quality in a changing environment; trends and explanation, Proceedings of symposium, International Union of Geodesy and Geophysics, Vienna, Austria, August 11-24, 1991: International Association of Hydrological Sciences Publication 203, p. 293-302.

1074. Stein, M., 1972, Conference on the matter of pollution of the interstate waters of the Colorado River and its tributaries, seventh session: U.S. Environmental Protection Agency, 2 v., 1142 p. plus appendices, with proceedings of reconvened 7 th session, $178 \mathrm{p}$.

1075. Stevens, B.K., Vaux, H.J., Jr., Young, R.A., Gardner, R.L., and Sparling, E.W., 1990, Discussion and reply on Assessing strategies for control of irrigation-induced salinity in the Upper Colorado River Basin, by R.L. Gardner and R.A. Young, 1988 (in American Journal of Agricultural Economics, v. 70, no. 1, p. 37-49): American Journal of Agricultural Economics, v. 72 , no. 2 , p. $493-496,497-4$.

The comment by Stevens and Vaux (SV) argues that in their analysis of the cost effectiveness and relative cost shares of alternative salinity control strategies in the Grand Valley, Gardner and Young (GY) inadequately address two issues. First, it has been shown that cost-effective input incentives require both a water tax and an irrigation system subsidy, irrespective of the consequences for cost shares. Second, by neglecting the income effect associated with the assignment of water quality entitlements to irrigators, GY may underestimate the resultant salt loads. The comment addresses these two issues in turn. In reply, Young, Gardner and Sparling concede that in a first-best neoclassical world modeled with continuously differentiable functions, SV's results would hold but that GY's results indicate practical implications of plausible policies in an imperfect world. Whilst agreeing with the second point, it is argued that whilst theoretically accurate, including income effects has little practical significance in the study area.

1076. Stevens, M.A., 1988, AB Lateral hydropower project, changes in river morphology: Grand Junction, Colo., HDR Engineering, Inc., and Bureau of Reclamation, $16 \mathrm{p}$.

1077. Stewart, K.C., Crock, J.G., and Severson, R.C., 1993, Chemical results and variability assessment of selected water-extractable constituents from soils of the Uncompahgre Project area, westcentral Colorado: U.S. Geological Survey Open-File Report 93-507, 27 p. 
1078. Stillwater, L.C., 1993, Upper Colorado River simulation/optimization model, in Burton, J.S., comp., Proceedings of the Federal interagency workshop on hydrologic modeling demands for the 90's: U.S. Geological Survey Water-Resources Investigations Report 93-4018, p. 7.7-7.13.

A monthly simulation/optimization model of the Upper Colorado River system provides decision support to an operator who is required to schedule monthly releases based on inflow forecasts when limited competing water-use objectives exist. The model simulates real-time monthly release decisions for the five major reservoirs (Fontenelle, Blue Mesa, Flaming Gorge, Navajo, and Lake Powell) and four major powerplants of the Upper Colorado River Basin. Model input includes weighting factors which define priorities for each water-use objective, historic forecasting inflows, historic actual inflows, target end-of-month storage contents for July and December, and preferred release hydrographs for each reservoir. Model output includes the total monthly releases, power releases, spills, and end-of-month storage volumes for the period of record, as each would have occurred under the operating priorities specified by the user. At each month of simulation a dynamic programming (DP) algorithm is called to determine the monthly release volumes for the current month through the next target month. The DP algorithm optimally distributes the excess water according to the penalty value accumulated due to violations of the weighted objectives. The accuracy of monthly forecasted inflows determines the degree to which a preferred hydrograph can be matched. The user exercises the most control over the general shape and total volume of the release hydrographs through priorities assigned to the redistribution of water in excess of the preferred hydrographs.

1079. Stockton, C.W., and Jacoby, G.C., Jr., 1976, Long-term surface-water supply and streamflow trends in the Upper Colorado River Basin based on tree-ring analyses: National Science Foundation Report NSF/RA-760410, 80 p. [Available from National Technical Information Service, Springfield, VA 22161 as NTIS Report PB-264 533/1.]

The long-term annual runoff was reconstructed for 12 selected streamgage stations within the Upper Colorado River Basin. These gaged records were analyzed to determine homogeneity, streamflow trends, and periodicities, and were compared to other records within the Basin. Three long-term reconstructed hydrographs for the total annual flow at the Colorado River Compact Point were calculated and compared. Records show that the early part of the twentieth century was one of anomalously persistent high runoff from the Colorado River Basin, and that it apparently was the greatest and longest high-flow period within the last 450 years. When the results of the analysis are viewed in the context of future demand for water usage in the Upper Colorado River Basin, it is apparent that projected demand could soon outstrip the natural annual supply of surface water. This situation probably would necessitate shifts in water-use priorities, with current agricultural and recreational allotments being diverted to those needed to meet energy, municipal, and industrial demands.

1080. Stottlemyer, R., and Troendle, C.A., 1988, Factors responsible for long-term trends in stream water chemistry, Fraser Experimental Forest, Colorado, in Poppoff, I.G., Goldman, C.R., Loeb, S.L., and Leopold, L.B., eds., International mountain watershed symposium--Subalpine processes and water quality, Lake Tahoe, California, June 8-10, 1988: South Lake Tahoe, Calif., Tahoe Resource Conservation District, p. 116-136.

138 Bibliography, Indices, and Data Sources of Water-Related Studies, Upper Colorado River Basin, Colorado and Utah, 1872-1995 
1081. Strand, R.I., Boesch, B.E., and Kruse, E.G., 1981, Salinity control--The Colorado River experience, in Proceedings of the speciality conference Water Forum '81--Host, San Francisco Section, ASCE [American Society of Civil Engineers], Sheraton Palace Hotel, San Francisco, California, August 10-14, 1981: New York, N.Y., American Society of Civil Engineers, p. 543-550.

This paper outlines a salinity control program to reduce the salt loading from several natural and manmade sources. The control program is necessary to maintain salinity standards that have been adopted for the river and to meet international obligations to Mexico by offsetting the increases in salinity that can be expected from additional water resource development. Completion of all identified salinity control projects would reduce salt loading by about 2 million tons. Two irrigation source improvement projects in the Grand Valley of Colorado and the Wellton-Mohawk Irrigation and Drainage District in Arizona are described in detail.

1082. Strand, R.I., Prichett, H.R., Boesch, B.E., Keys, J.W., Kruse, E.G., and Swenson, R.S., 1981, Irrigation in the Colorado River Basin, USA--Solving the salinity problem to save a giant: Eleventh Congress on Irrigation and Drainage, ICID, Grenoble, France, Vol. III, Question 36, Pt. II, Transactions, p. 807-823.

1083. Suffern, J.S., West, D.C., Kemp, H.T., and Burgess, R.L., 1976, Biological monitoring and selected trends in environmental quality: Oak Ridge, Tenn., Oak Ridge National Laboratory, $34 \mathrm{p}$. [Available from National Technical Information Service, Springfield, VA 22161 as NTIS Report ORNL/TM-5606.]

Under a contract with the President's Council on Environmental Quality, the National Inventory of Selected Biological Monitoring Programs at Oak Ridge National Laboratory was used to identify documented environmental trends. Fish population trends were described for the Great Lakes and the Colorado River system. Trends in amphibian populations in the northeast were examined and correlated with acid precipitation. Increases in breeding success among large birds of prey were correlated with reductions in ambient levels of DDT and its residues. Geographic variation in PCB contamination was examined along with differences between aquatic and terrestrial contamination levels. Changes in air quality were documented, and their effects on plant viability were outlined. Trends in the biological effects of environmental deposition of lead were documented. Long-term changes in forest structure in the southeast were presented, and a general reduction in wildlife habitat, associated with land use practices, was documented for several areas in the U.S.

1084. Sunday, G., 1979, Role of rill development in salt loading from hillslopes: Fort Collins, Colo., Colorado State University, Master's thesis. [Available from National Technical Information Service, Springfield, VA 22161 as NTIS Report PB-80 199 540, 120 p.; NTIS Report PB-80 152 044, 107 p.]

A field study, a computer simulation, and flow velocity experiments were used to identify the major contributing factors in salt loading of the Colorado River from hillslopes above the river. The field study of artificially induced runoff over Mancos Shale was conducted on sites with little vegetation located north of the Grand Junction, Colorado, airport and in the West Salt Creek Basin near Mack, Colorado. The longitudinal slopes ranged from 7 to 41 degrees with lengths of from 40 to 225 feet. 
1085. Sundeen, K.D., 1983, Analysis of wetland conditions, Fall and Cross Creeks: U.S. Department of Agriculture, Forest Service, White River National Forest, 36 p.

1086. Sundeen, K.D., Leaf, C.F., and Bostrom, G.M., 1989, Hydrologic functions of sub-alpine wetlands in Colorado, in Fisk, D.W., ed., Proceedings of the symposium on wetlands-Concerns and successes, Tampa, Florida, September 17-22, 1989: Bethesda, Md., American Water Resources Association Technical Publication Series TPS-89-3, p. 401-413.

1087. Tarlock, A.D., 1985, Lessons from the rest of the west--A survey of groundwater management in California, Colorado, New Mexico, and Nebraska, in Smerdon, E.T., and Jordan, W.R., eds., Issues in groundwater management, proceedings of a symposium on groundwater--Crisis or opportunity, San Antonio, Texas, October 29-31, 1984: Austin, Tex., University of Texas Center for Research in Water Resources, p. 165-173.

Groundwater has characteristics that make State intervention in its use necessary. These are: (1) relative scarcity, (2) absolute scarcity, and (3) contamination. This paper focuses on the first two characteristics. Relative scarcity occurs when pumpers in a basin cannot obtain required amounts at pre-existing pumping levels. Unlike surface streams, groundwater basins may not be sucked dry in any given year. Rather, any shortage that occurs is not to an absolute amount but to an amount of water at a given pressure head. Economists advise that in order to promote the efficient allocation of resources, property rights must be well defined, enforced, and transferable. Well-defined rights are basically rights that make clear, exclusive assignments to one entity. The other two attributes, enforceability and transferability, follow from an exclusive assignment. Once an individual sphere of control is delineated, it is possible to determine what is an interference and to protect the right holder against it. Clear and enforceable rights are obviously saleable items, if the resource has value, and thus the right is transferable. With respect to groundwater, the sticky point is the first characteristic of property right. It is difficult to assign exclusive rights to a resource when, for physical reasons, one claimant's consumption inevitably interferes with another claimant's legitimate consumption. A survey of groundwater law and administration in California, Colorado, New Mexico, and Nebraska shows that no State has developed a solution to the twin problems of pressure declines and mining. Groundwater control is rooted in the needs of each State, and as a result, one State's institutions are not readily transferable to another State; but taken together, the experience of the States surveyed here illustrate some realistic approaches to groundwater conservation.

1088. Taylor, G., 1978, Wastewater treatment facilities, Three Lakes, Colorado (final environmental impact statement): U.S. Environmental Protection Agency Report EPA 908/5-78-002. [Available from National Technical Information Service, Springfield, VA 22161 as NTIS Report PB-283 354.]

This EIS describes and analyzes the environmental impacts of a proposed regional sewage collection and treatment system for the Three Lakes Water and Sanitation District, Colorado. The proposed sewerage system will serve presently unsewered developed areas, eliminate present sub-standard septic tank and treatment plant discharge to the lakes, and discharge a properly treated effluent to a stream nontributary to the lakes. Growth and non-point issues are being addressed by Grand 
County. The project is expected to result in water quality and land use improvement for the Three Lake area.

1089. Taylor, O.J., 1982, Hydrologic-information needs for oil-shale development, northwestern Colorado: U.S. Geological Survey Water-Resources Investigations Report 82-4076, 92 p.

1090. Taylor, O.J., 1982, Three-dimensional mathematical model for simulating the hydrologic system in the Piceance Basin, Colorado: U.S. Geological Survey Water-Resources Investigations Open-File Report 82-637, 35 p.

1091. Taylor, O.J., 1986, Simulation of mine drainage for a preliminary development of oil shale and associated minerals, Piceance Basin, northwestern Colorado: U.S. Geological Survey WaterResources Investigations Report 86-4011, 25 p.

1092. Taylor, O.J., 1987, Hydrologic system of Piceance Basin, in Taylor, O.J., comp., Oil shale, water resources, and valuable minerals of the Piceance Basin, Colorado--The challenge and choices of development: U.S. Geological Survey Professional Paper 1310, p. 63-76.

1093. Taylor, O.J., comp., 1987, Oil shale, water resources, and valuable minerals of the Piceance Basin, Colorado--The challenge and choices of development: U.S. Geological Survey Professional Paper 1310, 143 p.

1094. Taylor, O.J., Freethey, G.W., and Glover, K.C., 1986, Upper Colorado River Basin regional aquifer-system study, in Sun, R.J., ed., Regional-Aquifer System Analysis Program of the U.S. Geological Survey--Summary of projects, 1978-84: U.S. Geological Survey Circular 1002, p. $223-233$.

1095. Taylor, O.J., Hood, J.W., and Zimmerman, E.A., 1983, Plan of study for the Regional Aquifer Systems Analysis of the Upper Colorado River Basin in Colorado, Utah, Wyoming, and Arizona: U.S. Geological Survey Water-Resources Investigations Report 83-4184, 23 p.

1096. Taylor, O.J., Hood, J.W., and Zimmerman, E.A., 1986, Hydrogeologic framework of the Upper Colorado River Basin--excluding the San Juan Basin--Colorado, Utah, Wyoming, and Arizona: U.S. Geological Survey Hydrologic Investigations Atlas HA-687, 2 sheets, scale 1:3,000,000.

1097. Teller, R.W., and Chafin, D.T., 1986, Selected drill-stem test data for the Upper Colorado River Basin: U.S. Geological Survey Water-Resources Investigations 84-4146, 112 p.

1098. Teller, R.W., and Welder, F.A., 1983, Ground-water potential of the Leadville Limestone on the White River Uplift in Garfield and Rio Blanco Counties, Colorado: U.S. Geological Survey Water-Resources Investigations Report 83-4036, 28 p.

1099. Theobald, P.K., Lakin, H.W., and Hawkins, D.B., 1963, The precipitation of aluminum, iron, and manganese at the junction of Deer Creek with the Snake River in Summit County, Colorado: Geochimica et Cosmochimica Acta, v. 27, no. 2, p. 121-132.

1100. THK Associates, Inc., 1974, Impact analysis and development patterns related to an oil shale industry--Regional development and land use study: Colorado West Area Council of Governments and Oil Shale Regional Planning Commission, 137 p. 
1101. Thomas, G.W., and Crawford, A.B., 1978, The role of agriculture, in Peterson, D.F., and Crawford, A.B., eds., Values and choices in the development of the Colorado River Basin: Tucson, Ariz., University of Arizona Press, p. 156-172.

Increasingly, values and choices in determining proper land and water use should be based on ecological considerations. Despite the needs of energy and recreation users such considerations should remain paramount in all planning developments. If this is done then the economy and potential development of the Colorado River Basin will remain competitive so far as agriculture and grazing is concerned.

1102. Thomas, N.O., and Harbeck, G.E., Jr., 1956, Reservoirs in the United States: U.S. Geological Survey Water-Supply Paper 1360-A, 99 p.

1103. Thompson, J.R., 1968, Effect of grazing on infiltration in a western watershed: Journal of Soil and Water Conservation, v. 23, no. 2, p. 63-65.

1104. Thompson, J.R., 1986, Cloud seeding, data collection and analysis associated with the Colorado River Augmentation Demonstration Program, 1985-86 season: Salt Lake City, Utah, North American Weather Consultants, 109 p. [Available from National Technical Information Service, Springfield, VA 22161 as NAWC Report WM 86-7.]

Limited experimental cloud seeding was conducted for the first time as a part of the Colorado River Augmentation Demonstration Program (CRADP) during the 1985-86 winter season. The cloud seeding occurred over the Grand Mesa region of western Colorado. Seeding activities, which included aerial and ground releases of silveriodide-ammonium iodide-acetone, were associated with three research studies, i.e., microphysical experiments, transport and dispersion of seeded plumes, and systems reliability testing of a new prototype cloud seeding generator. Results obtained from the climatological studies from one winter season (about two months) of cloud seeding have clearly demonstrated that not only is the Grand Mesa an ideal place to conduct weather modification research, but also appears to be a very suitable laboratory that contains an atmosphere which is amenable to cloud seeding effects. More data needs to be acquired from a larger sample of meteorological conditions to provide the sort of information needed to improve cloud seeding technology in the Colorado River Basin. Several transport and dispersion ( $T$ and $D$ ) studies were made during the 1985-86 field season which have provided valuable information about the action of seeding plumes released from the ground or an aircraft. Ground released plumes were frequently observed to reach an altitude two thousand feet above the Mesa top, suggesting that ground seeding would be an effective delivery system. Measurements of liquid water, made with a microwave radiometer, have documented the frequent occurrence of liquid water in association with $700 \mathrm{mb}$ wind flow from the south or southwest. Data from the icing rate meters at Rapid Creek and the WAPA tower substantiate that liquid water is most frequently observed with 'southerly' flow but not to the extent the radiometer data suggests. The icing rate meter data clearly indicates the highest per hour average (in $\mathrm{g} / \mathrm{cu} \mathrm{m}$ ) occurs with 'northerly' flow. There is some question as to the validity of the radiometer data with northerly flow since air passing over the radiometer is in a descending mode and is losing liquid water. A specific recommendation would be to locate the radiometer on top of the Mesa to acquire the most representative liquid water measurements possible. 
1105. Thompson, K.R., 1985, Annual suspended-sediment loads in the Colorado River near Cisco, Utah, 1930-82: U.S. Geological Survey Water-Resources Investigations Report 85-4011, 19 p.

1106. Thorne Ecological Institute, 1973, Environmental setting of the Parachute Creek Valley-An ecological inventory: Denver, Colo., Atlantic Richfield Company, 173 p.

1107. Thorne Ecological Institute, 1973, The Colony environmental study--Parachute Creek, Garfield County, Colorado, part III: Denver, Colo., Atlantic Richfield Company.

1108. Thorne, D.W., 1974, The development and environmental protection of the Colorado River Basin, in Crawford, A.B., and Peterson, D.F., eds., Environmental management in the Colorado River Basin: Logan, Utah, Utah State University Press, p. 298-313.

1109. Thornton, L.M., 1975, Applications of geomorphology to land-use planning and recreation at Blue Mesa Reservoir, Gunnison County, Colorado: Lawrence, Kans., University of Kansas, Master's thesis, $99 \mathrm{p}$.

1110. Tipton and Kalmbach, Inc., 1965, Water supplies of the Colorado River available for use by the States of the Upper Division and for use from the main stem by the States of Arizona, California, and Nevada in the Lower Basin [prepared for the Upper Colorado River Commission]: 24 p. plus tables and appendix.

1111. Torres, J., Bissell, S., Craig, G., Graul, W., and Langlois, D., 1978, Essential habitat for threatened or endangered wildlife in Colorado: Denver, Colo., Colorado Division of Wildlife, 87 p.

1112. Troendle, C.A., 1987, The effect of partial and clearcutting on streamflow at Deadhorse Creek, Colorado: Journal of Hydrology, v. 90. no. 1-2, p. 145-157.

1113. TRW, Inc., 1982, Hydrologic characterization of NOSR 1 [Naval Oil Shale Reserve No. 1]: U.S. Department of Energy Report DOE/RA/32012-T23, 169 p. [Available from National Technical Information Service, Springfield, VA 22161 as NTIS Report DE-84 006 947.]

The hydrologic characterization report for Naval Oil Shale Reserve No. 1 (NOSR 1) summarizes and analyzes the information obtained during the multi-year predevelopment program conducted for the U.S. Department of Energy. The compilation and analyses of this data define the baseline hydrologic conditions and provide important hydrologic information for input into development planning. Surface water discharge leaving NOSR 1 has been monitored by the U.S. Geological Survey since water year 1976. Total annual discharge has ranged from a low of 529.9 acre-feet in water year 1977 , to a high of 18,296 acre-feet in water year 1979 . For water years 1979 and 1980, total annual surface water discharge in area-inches was 7.37 (18,296 acre-feet) and 6.96 (17,269 acre-feet), respectively. A comparison of these figures to the estimated total annual precipitation of the same years shows between $25 \%$ and $30 \%$ of total annual precipitation leaves NOSR 1 as surface water runoff. Overall quality of surface water on NOSR 1 is good and meets the EPA's standards for drinking water. Evapotranspiration is estimated to range up to approximately 19 inches. This estimate was based on a study of an adjacent property, and adjusting values from that study for the vegetation distribution on NOSR 1 . The groundwater system on NOSR 1 consists of four principal water-bearing zones. Zone 1 is found in the upper part of the Parachute Creek Member above the Big Three rich zone. This 
water-bearing zone, with an average thickness of about 170 feet, is generally unconfined, in contrast to the lower zones. Calculated transmissivities range from a high of $449 \mathrm{sq} \mathrm{ft} /$ day in well 22, to a low of $1.2 \mathrm{sq} \mathrm{ft} /$ day in Well 15/16. Zone 2, located in the vicinity of the 'A' Groove, has an average thickness of 20 feet. Calculated transmissivities for this zone range from 0.9 to $105.9 \mathrm{sq} \mathrm{ft} / \mathrm{day}$. Zone 3 is located in the vicinity of the B-Groove. This zone has an average thickness of 70 feet and has somewhat higher calculated transmissivities and hydraulic conductivities than those for the other three zones. Calculated transmissivities range from 10.9 to $529 \mathrm{sq} f t / d a y$. Zone 4 is found below the base of the R-6 zone. On NOSR 1, this zone has an average thickness of 170 feet. Generally, the calculated values of transmissivity and hydraulic conductivity are low and variable depending on geographic location. Calculated transmissivity ranges from a low of $0.8 \mathrm{sq} \mathrm{ft} / \mathrm{day}$ at Well 15/16, to a high of $48.5 \mathrm{sq} \mathrm{ft} / \mathrm{day}$ at Well 17.

1114. Turk, J.T., 1982, Thermodynamic controls on quality of water from underground coal mines in Colorado: Water Resources Bulletin, v. 18, no. 1, p. 75-80.

1115. Turner, G.T., 1971, Soil and grazing influences on a salt-desert shrub range in western Colorado: Journal of Range Management, v. 21, no. 1, p. 31-37.

1116. Turner, G.T., and Dortignac, E.J., 1954, Infiltration, erosion, and herbage production of some mountain grasslands in western Colorado: Journal of Forestry, v. 52, p. 858-860.

1117. Tweto, O., 1979, Geologic map of Colorado: U.S. Geological Survey, scale 1:500,000.

1118. Twiss, R.H., 1974, Strategies for environmental planning in the Upper Colorado River region, in Crawford, A.B., and Peterson, D.F., eds., Environmental management in the Colorado River Basin: Logan, Utah, Utah State University Press, p. 102-118.

1119. Tyus, H.M., 1984, Loss of stream passage as a factor in the decline of the endangered Colorado squawfish, in Issues and technology in the management of impacted western wildlife, proceedings of a national symposium: Boulder, Colo., Thorne Ecological Institute Technical Publication 14, p. 138-144.

1120. Tyus, H.M., 1986, Life strategies in the evolution of the Colorado squawfish (Ptychocheilus lucius): Great Basin Naturalist, v. 46, no. 4, p. 656-661.

1121. Tyus, H.M., 1991, Ecology and management of Colorado squawfish, in Minckley, W.L., and Deacon, J.E., eds., Battle against extinction--Native fish management in the American west: Tucson, Ariz., University of Arizona Press, p. 379-402.

1122. Tyus, H.M., 1992, An instream flow philosophy for recovering endangered Colorado River fishes: Rivers, v. 3, no. 1, p. 27-36.

1123. Tyus, H.M., 1992, Instream flow philosophy for recovering endangered Colorado River fishes: U.S. Fish and Wildlife Service, Colorado River Recovery Implementation Program Reports. 
1124. Tyus, H.M., Burdick, B.D., Valdez, R.A., Haynes, C.M., Lytle, T.A., and Berry, C.R., 1982, Fishes of the Upper Colorado River Basin--Distribution, abundance, and status, in Miller, W.H., Tyus, H.M., and Carlson, C.A., eds., Fishes of the Upper Colorado River system--Present and future: Western Division of the American Fisheries Society, p. 12-18, 64-70.

1125. U.S. Army Corps of Engineers, 1963, Benefits from flood control - Dallas Creek Project, Uncompahgre River, Colorado: Los Angeles, Calif., U.S. Army Corps of Engineers.

1126. U.S. Army Corps of Engineers, 1973, Flood plain information--Colorado and Gunnison River, Grand Junction, Colorado: Sacramento, Calif., U.S. Army Corps of Engineers, 24 p.

1127. U.S. Army Corps of Engineers, 1973, Flood plain information--Roaring Fork River and Castle and Hunter Creeks, Aspen, Colorado: Sacramento, Calif., U.S. Army Corps of Engineers, 30 p.

1128. U.S. Army Corps of Engineers, 1975, Colorado water resources development: Omaha, Nebr., U.S. Army Corps of Engineers, 54 p.

1129. U.S. Army Corps of Engineers, 1976, Flood hazard information--Colorado River and tributaries, Grand Junction, Colorado: Sacramento, Calif., U.S. Army Corps of Engineers, 11 p:

1130. U.S. Army Corps of Engineers, 1976, Flood hazard information--Colorado River, Palisade, Colorado: Sacramento, Calif., U.S. Army Corps of Engineers, 5 p.

1131. U.S. Army Corps of Engineers, 1976, Flood hazard information--Gunnison River and tributaries, Fruita, Colorado: Sacramento, Calif., U.S. Army Corps of Engineers, 9 p.

1132. U.S. Army Corps of Engineers, 1980, Flood hazard information, North Fork Gunnison River, Hotchkiss to Somerset, Delta and Gunnison Counties, Colorado (Gunnison and Uncompahgre Rivers): Sacramento, Calif., U.S. Army Corps of Engineers, 11 p.

1133. U.S. Congress Senate Subcommittee on Energy Research and Development, 1979, Amending Title I of the Colorado River Basin Salinity Control Act: U.S. Government Printing Office Pub. 96-18, U.S. Congress, 96th, 1st session, 127 p.

1134. U.S. Department of Agriculture, 1957, Paonia Project, Colorado, Colorado River Storage Project-A report on reappraisal of direct agricultural benefits and project impacts: Salt Lake City, Utah, U.S. Department of Agriculture, $68 \mathrm{p}$.

1135. U.S. Department of Agriculture, 1983, 1983 annual report, Colorado River Basin Salinity Control Program: U.S. Department of Agriculture, 24 p.

1136. U.S. Department of Energy, 1986, Remedial actions at the former Climax Uranium Company uranium mill site, Grand Junction, Mesa County, Colorado, draft environmental impact statement, volume 1, text: U.S. Department of Energy Report DOE/EIS-0126-D-V.1, 259 p. [Available from National Technical Information Service, Springfield, VA 22161 as NTIS Report DE-86 009 138/XAB.]

This statement evaluates and compares the environmental impacts associated with the remedial actions of the residual radioactive materials remaining at the inactive uranium processing site and associated vicinity properties at Grand Junction, Mesa County, Colorado. The site is a 114-acre tract of private and state owned land which 
contains approximately 3.1 million cubic yards of tailings and associated contaminated soils. The vicinity properties are homes, businesses, public buildings, and vacant lots which may have been contaminated during construction by the use of tailings as building material. An estimated 3465 vicinity properties would be cleaned up during remedial action of the tailings pile. This statement evaluates six alternatives for stabilization and disposal of the tailings and other contaminated materials: no action, stabilization at the Grand Junction site, disposal at the Cheney Reservoir site with truck transport, disposal at the Cheney Reservoir site with train and truck transport, disposal at the Two Road site with truck transport, and disposal at the Two Road site with train and truck transport. All of the alternatives except [document illegiblel include remedial action at an estimated 3465 vicinity properties. Alternative 3 is DOE's preferred alternative.

1137. U.S. Department of Energy, 1986, Remedial actions at the former Climax Uranium Company uranium mill site, Grand Junction, Mesa County, Colorado, final environmental impact statement, volume 1, text, volume 2, appendices: U.S. Department of Energy Report DOE/EIS-0126-F, various pagination.

1138. U.S. Department of Energy, 1987, Remedial actions at the former Union Carbide Corporation uranium mill sites, Rifle, Garfield County, Colorado, draft environmental impact statement: U.S. Department of Energy Report DOE/EIS-0132-D, 2 volumes.

1139. U.S. Department of Energy, 1991, Remedial action plan and site design for stabilization of the inactive uranium mill tailings site at Grand Junction, Colorado, attachment 3, groundwater hydrology report, final: U.S. Department of Energy Report DOE/AL/050505.0000, 557 p.

1140. U.S. Department of Energy, 1992, Remedial action plan and site design for stabilization of the inactive uranium mill tailings site at Gunnison, Colorado, attachment 3, groundwater hydrology report, final: U.S. Department of Energy Report DOE/AL/-050508.0000, 64 p.

1141. U.S. Department of Energy, 1992, Site-specific analysis of the cobbly soils at the Grand Junction processing site: Albuquerque, N. Mex., U.S. Department of Energy, 162 p. [Available from National Technical Information Service, Springfield, VA 22161 as NTIS Report DE-93 010392 / XAB.]

This report describes a recent site-specific analysis to evaluate the necessity of a recommendation to install a slurry trench around the Grand Junction processing site. The following analysis addresses the cobbly nature of the site's radiologically contaminated foundation soil, reassesses the excavation depths based on bulk radionuclide concentrations, and presents data-based arguments that support the elimination of the initially proposed slurry trench. The slurry trench around the processing site was proposed by the Remedial Action Contractor (RAC) to minimize the amount of water encountered during excavation. The initial depths of excavation developed during conceptual design, which indicated the need for a slurry wall, were reexamined as part of this analysis. This reanalysis, based on bulk concentrations of a cobbly soil, supports decreasing the original excavation depth, limiting the dewatering quantities to those which can be dissipated by normal construction activities. This eliminates the need for a slurry trench and separate water treatment prior to permitted discharge. 
1142. U.S. Department of Energy, 1994, UMTRA Project water sampling and analysis plan, Gunnison, CO: U.S. Department of Energy Report DOE/AL/62350-139, REV. 1, various pagination.

1143. U.S. Department of Energy, 1994, Work plan for ground water elevation data recorder/monitor well installation at Gunnison, CO: U.S. Department of Energy Report DOE/AL/62350-139, REV. 2, various pagination.

1144. U.S. Department of Housing and Urban Development, 1977, Flood hazard boundary maps, Gunnison County, Colorado, unincorporated areas: Federal Insurance Administration.

1145. U.S. Department of the Interior, 1973, Final environmental statement for the prototype oil shale leasing program; volume I, regional impacts of oil shale development; volume II, energy alternatives; volume III, specific impacts of prototype oil shale development; volume IV, consultation and coordination with others; volume $V$, letters received during review process; volume VI, public hearings held during the review process: Washington, D.C., U.S. Department of the Interior, various pagination.

1146. U.S. Department of the Interior, 1980, Upper Colorado resource study, Colorado and Utah; concluding report: U.S. Department of the Interior, $156 \mathrm{p}$.

1147. U.S. Environmental Protection Agency, 1970, Water quality conditions in Grand Lake, Shadow Mountain Lake, and Lake Granby: San Francisco, Calif., U.S. Environmental Protection Agency, 62 p.

1148. U.S. Environmental Protection Agency, 1971, The mineral quality problem in the Colorado River Basin, appendix A, natural and man-made conditions affecting mineral quality: Denver, Colo., U.S. Environmental Protection Agency, 189 p. [Available from National Technical Information Service, Springfield, VA 22161 as NTIS Report PB-230 716/3.]

The study includes a thorough review of factors which affect mineral quality of streams; review of previous investigations of the mineral quality problems in the Colorado River Basin and other similar basins; a rigorous statistical analysis of existing mineral quality data; and extensive field studies to determine the location and magnitude of salinity sources throughout the Colorado River Basin.

1149. U.S. Environmental Protection Agency, 1971, The mineral quality problem in the Colorado River Basin, appendix B, physical and economic impacts: Denver, Colo., U.S. Environmental Protection Agency, 178 p. [Available from National Technical Information Service, Springfield, VA 22161 as NTIS Report PB-230 391/5.]

Salinity is one of the most serious water quality problems in the Colorado River Basin. As a part of its overall study of the salinity problem, the Colorado River Basin Water Quality Control Project (Project) carried out detailed studies to evaluate the physical and economic impacts associated with anticipated degradation in the mineral quality of Colorado River water. The methods of investigation and the results of these studies are presented in this appendix. 
1150. U.S. Environmental Protection Agency, 1971, The mineral quality problem in the Colorado River Basin, appendix C, salinity control and management aspects: Denver, Colo., U.S. Environmental Protection Agency, 143 p. [Available from National Technical Information Service, Springfield, VA 22161 as NTIS Report PB-230 392/3.]

Salinity is one of the most serious water quality problems in the Colorado River Basin. As a part of its investigation of interstate pollution problems, the Colorado River Basin Water Quality Control Project (Project) has carried out activities since 1963 directed toward the salinity problem. The objectives of this appendix are to evaluate the net basinwide economic benefits associated with various degrees of control, and to investigate and evaluate feasible methods of controlling and minimizing salinity concentrations and loads in the river.

1151. U.S. Environmental Protection Agency, 1971, The mineral quality problem in the Colorado River Basin, appendix D, comments on draft report: Denver, Colo., U.S. Environmental Protection Agency, 72 p. [Available from National Technical Information Service, Springfield, VA 22161 as NTIS Report PB-230 173/7.]

The more significant findings and data from the salinity studies and related pertinent information are summarized in the report entitled 'The Mineral Quality Problem in the Colorado River Basin'. Detailed information pertaining to the methodology and findings of the Project's salinity studies are presented in three appendices to that report. Copies of the draft report, including the three appendices, were distributed to state and Federal government agencies. Comments received in response to that distribution are included in this appendix. The comments are organized alphabetically by state.

1152. U.S. Environmental Protection Agency, 1971, The mineral quality problem in the Colorado River Basin, summary report: Denver, Colo., U.S. Environmental Protection Agency, 73 p. [Available from National Technical Information Service, Springfield, VA 22161 as NTIS Report PB-230 389/9.]

The Colorado River system carries a large salt burden (dissolved solids) contributed by a variety of natural and man-made sources. Salinity investigations are summarized in this report. A broad range of studies was carried out which included intensive, short-term water quality field investigations, long-term water quality monitoring, mathematical simulation of water quality relationships, reconnaissance level evaluation of specific salinity control measures, and detailed economic studies.

1153. U.S. Environmental Protection Agency, 1971, Water quality evaluation of the Grand Mesa Project, Colorado: Denver, Colo., U.S. Environmental Protection Agency, 21 p. [Available from National Technical Information Service, Springfield, VA 22161 as NTIS Report PB-245 803/2.]

An evaluation of the Bureau of Reclamation's proposed Grand Mesa Project indicates that with adequate treatment, municipal, industrial and other domestic waste. loadings should not significantly affect water quality for present and projected water uses in the project area. Therefore, no storage in Electric Mountain and Cactus Park reservoirs is needed to provide flow regulation for maintaining satisfactory water quality in the Gunnison River. Control measures are recommended for incorporation 
into construction and operation of the project to mitigate the adverse effects of increased salinity.

1154. U.S. Environmental Protection Agency, 1972, Pollution of the interstate waters of the Colorado River and its tributaries; Colorado, New Mexico, Arizona, California, Nevada, Wyoming and Utah, proceedings of conference session (7th), Las Vegas, Nevada, February 15-17, 1972: Washington, D.C., U.S. Environmental Protection Agency, 724 p. [Available from National Technical Information Service, Springfield, VA 22161 as NTIS Report PB-230 750/2.]

The report is the seventh session of the conference on pollution of the interstate waters of the Colorado River and its tributaries - Colorado, New Mexico, Arizona, California, Nevada, Wyoming and Utah for 1972. It includes statements, discussions, and recommendations on: comparison of salinity projections, changes in water quality above Hoover Dam, and related information.

1155. U.S. Environmental Protection Agency, 1972, Proceedings of reconvened session of the conference in the matter of pollution of the interstate waters of the States of California, Colorado, Utah, Arizona, Nevada, New Mexico, and Wyoming (7th), Denver, Colorado, April 26-27, 1972: Washington, D.C., U.S. Environmental Protection Agency, 183 p. [Available from National Technical Information Service, Springfield, VA 22161 as NTIS Report PB-255 581/1.]

The report is on the seventh session of the conference in the matter of pollution of the interstate waters of the Colorado River and its tributaries in the states of California, Colorado, Utah, Arizona, Nevada, New Mexico, and Wyoming for 1972. It includes statements, discussions, and recommendations on: water quality improvement programs; concentrations of total dissolved solids; water quality data; and related information.

1156. U.S. Environmental Protection Agency, 1972, Report of steering committee on salinity control of irrigation return flows: Denver, Colo., U.S. Environmental Protection Agency, 33 p. [Available from National Technical Information Service, Springfield, VA 22161 as NTIS Report PB-255 566/2.]

The paper has as its purpose a definition of the salinity problem, the enunciation of a proposed Environmental Protection Agency policy for control of salinity from irrigated agriculture, and a recommended course of action to implement those portions of the Federal Water Pollution Control Act (PL 92-500) pertinent to this problem. The water quality problems associated with irrigation return flows are of special concern because irrigated agriculture is the largest consumer of water resources.

1157. U.S. Environmental Protection Agency, 1972, Water quality management analysis of Summit County, Colorado: Denver, Colo., U.S. Environmental Protection Agency, 138 p. [Available from National Technical Information Service, Springfield, VA 22161 as NTIS Report PB-256 463.]

Summit County, Colorado, and the Blue River hydrologic basin are experiencing a period of dramatic growth in the demand for water and sewer services, generated primarily by the growth of several recreation oriented communities and developments. This development has a significant impact on water quality. 
Projections indicate that construction of vastly expanded wastewater treatment facilities will be required, resulting in a dramatic rise in the concentration of nutrients within local reservoirs. Non-point sources of pollution from construction and leaching landfills also add to the nutrient levels. Projected inorganic nitrogen levels will result in a possible eutrophic condition in the reservoirs. Land use controls were investigated as an alternative to wastewater treatment and the EPA found this possibility inadequate. The report indicates the most desirable alternative is the exportation of wastes from the river basin. The final recommendations included maintenance of current nutrient levels and additional monitoring of pollutant discharges and their resultant effects on water quality.

1158. U.S. Environmental Protection Agency, 1973, Radium-226, uranium, and other radiological data collected from water quality surveillance stations located in the Colorado River Basin of Colorado, Utah, New Mexico, and Arizona, January, 1961 through June, 1972:

U.S. Environmental Protection Agency Report 8SA/TIB-24, 272 p. [Available from National Technical Information Service, Springfield, VA 22161 as NTIS Report PB-244 920/5.]

The RMN ('Radiological' or 'Radium Monitoring Network') System was established in 1961 at the direction of the 'Conference on the Matter of Interstate Pollution of the Colorado River and its Tributaries' and has continued to produce measurements of radium-226, total uranium, and other surface water parameters affected by the occurrence, extraction, and refining of uranium ore in the Colorado River Basin. The report presents all of the available data supplied by the RMN System to date. The report also examines certain of these data in terms of their long- and short-term trends. In excess of 3000 measurements of radium-226 and uranium in the dissolved state are presented as are many measurements of other radioactivity parameters.

1159. U.S. Environmental Protection Agency, 1973, Technical assistance project, Upper Eagle Valley Sanitation District wastewater treatment facility-Avon, Colorado, March-April, 1973: Denver, Colo., U.S. Environmental Protection Agency, 17 p. [Available from National Technical Information Service, Springfield, VA 22161 as NTIS Report S\&A-TSB-23.]

Findings of the Environmental Protection Agency (EPA) technical assistance project involving the Upper Eagle treatment plant near Vail, Colorado, are presented. Treatment at the Upper Eagle plant includes pretreatment with bar screening, aeration, clarification, aerobic digestion, chlorination, sludge drying, and discharge of effluents to the Eagle River. EPA control testing at the facility included measurements of dissolved oxygen, centrifuge turbidity, settleability, and sludge blanket depth. Results indicated that plant performance was hindered by inadequate control over the return sludge flow rate caused by insufficient manpower at the facility and inadequate physical control. Other limitations were posed by the size of the aeration basin, the aerobic digester capabilities, and leaky seals in the final clarifier. Biological activity and adequate sludge digestion were limited by cold temperature, inadequate detention times, and excessive solids loading to the digester. Also, no provisions existed for the removal of floating material. Suggestions by the EPA for modifications and additions to the Upper Eagle plant included monitoring of effluent quality and inflow rate, regular repair of clarifier seals, cooperative treatment by the Vail and Upper Eagle plants, enlargement of the aeration basin, covering and/or heating of the digester, removal of floatable material during final clarification, and an increase in plant staffing. 
1160. U.S. Environmental Protection Agency, 1974, Dillon Reservoir-Blue River study, Colorado, June, July, August 1973: Denver, Colo., U.S. Environmental Protection Agency, 35 p. [Available from National Technical Information Service, Springfield, VA 22161 as NTIS Report EPA-908/2-74-002.]

A study of existing nutrient levels in Dillon Reservoir (Colorado), and organic and nutrient contributions from major tributaries and wastewater treatment plants during summer 1973, showed that nitrogen concentrations were significant but not excessive and phosphorus levels were not less than $0.05 \mathrm{mg} / 1$ except at the outlets of the Blue River Arm and Dillon Bay. Phytoplankton growth indicated the reservoir is gradually changing from oligotrophy to a more enriched state; diatom bloom was observed in July. Algal assays on water from three reservoir locations indicated phosphorus limitation. High molybdenum levels, resulting from mining in the Ten Mile Creek watershed, were found at all cross-sections of the reservoir (mean -351 micrograms), especially at the outlet of Ten Mile Creek Arm. Highest concentrations were found near the bottom. Irrigation of forage crops with water from Ten Mile Creek of Dillon Reservoir could have toxic effects on livestock. Molybdenum algal assay showed existing concentrations in the reservoir have no effect on algal growth, however. Greatest tributary organic and phosphorus loading to the reservoir was in June from the Blue River $-2368 \mathrm{~kg}$ BOD5/day and $45 \mathrm{~kg} \mathrm{P} /$ day. Three sewage treatment plants discharge effluents directly to the reservoir (Frisco, East Dillon, and Summit County No. 1), Breckenridge STP discharges to the Blue River, and Copper Mountain STP discharges to Ten Mile Creek. Dillon Reservoir provides part of Denver's water supply.

1161. U.S. Environmental Protection Agency, 1974, Evaluation of the Colorado water supply program: Denver, Colo., U.S. Environmental Protection Agency, 144 p.

1162. U.S. Environmental Protection Agency, 1976, Preliminary report on Blue Mesa Reservoir, Gunnison County, Colorado, Colorado National Eutrophication Survey: Corvallis, Oreg., Las Vegas, Nev., Corvallis Environmental Research Laboratory, Environmental Monitoring and Support Laboratory, $44 \mathrm{p}$.

1163. U.S. Environmental Protection Agency, 1976, Proposed water quality management plan, Blue River Basin, Summit County, Colorado (draft environmental impact statement): Denver, Colo., U.S. Environmental Protection Agency, 179 p. [Available from National Technical Information Service, Springfield, VA 22161 as NTIS Report PB-257 042.]

The Federal Water Pollution Control Act requires the states to submit basin-wide plans to EPA for managing water quality. Under Section 3 (c) of the 1965 version of the Act, the State of Colorado has submitted a water quality management plan for the Blue River basin in Colorado. EPA's approval of the plan is subject of this environmental impact statement (EIS). 
1164. U.S. Environmental Protection Agency, 1977, Blue Mesa Reservoir, Gunnison County, Colorado: Corvallis, Oreg., National Eutrophication Survey Working Paper-767, 52 p. [Available from National Technical Information Service, Springfield, VA 22161 as NTIS Report PB-271 658.]

Annual total phosphorus and total nitrogen loadings to the lake were estimated and subdivided according to either point or non-point source origin. An assessment of the lake's trophic condition and limiting nutrient is also provided. All data collected by the U.S.E.P.A. National Eutrophication Survey during the one year study of the lake and its tributaries are included.

1165. U.S. Environmental Protection Agency, 1977, Dillon Reservoir, Summit County, Colorado: Corvallis, Oreg., National Eutrophication Survey Working Paper-769, 60 p. [Available from National Technical Information Service, Springfield, VA 22161 as NTIS Report PB-278 484.]

Annual total phosphorus and total nitrogen loadings to the lake were estimated and subdivided according to either point or non-point source origin. An assessment of the lake's trophic condition and limiting nutrient is also provided. All data collected by the U.S.E.P.A. National Eutrophication Survey during the one year study of the lake and its tributaries are included.

1166. U.S. Environmental Protection Agency, 1977, Grand Lake and Shadow Mountain Lake, Grand County, Colorado: Corvallis, Oreg., National Eutrophication Survey Working Paper-770, 52 p. [Available from National Technical Information Service, Springfield, VA 22161 as NTIS Report PB-272 233.]

Annual total phosphorus and total nitrogen loadings to the lake were estimated and subdivided according to either point or non-point source origin. An assessment of the lake's trophic condition and limiting nutrient is also provided. All data collected by the U.S.E.P.A. National Eutrophication Survey during the one year study of the lake and its tributaries are included.

1167. U.S. Environmental Protection Agency, 1977, Green Mountain Reservoir, Summit County, Colorado: Corvallis, Oreg., National Eutrophication Survey Working Paper-771, 43 p. [Available from National Technical Information Service, Springfield, VA 22161 as NTIS Report PB-272 235.]

Annual total phosphorus and total nitrogen loadings to the lake were estimated and subdivided according to either point or non-point source origin. An assessment of the lake's trophic condition and limiting nutrient is also provided. All data collected by the U.S.E.P.A. National Eutrophication Survey during the one year study of the lake and its tributaries are included.

1168. U.S. Environmental Protection Agency, 1977, Upper Eagle Valley and Vail wastewater facilities plan (attachment to final environmental impact statement): U.S. Environmental Protection Agency Report EPA-908/5-77-003B, 285 p. [Available from National Technical Information Service, Springfield, VA 22161 as NTIS Report PB-80 162 712.]

The purpose of the report is to present the possible environmental impacts of a wastewater treatment facility plan for eastern Eagle County, 120 miles (193 
kilometers) west of Denver, Colorado. The proposed federal action is the award of an EPA grant for partial funding of wastewater treatment works in Eagle County. This option is weighed against a no action alternative, as well as compared to other possible alternatives.

1169. U.S. Environmental Protection Agency, 1977, Upper Eagle Valley and Vail wastewater facilities plan (final environmental impact statement): U.S. Environmental Protection Agency Report EPA-908/5-77/003A, 105 p. [Available from National Technical Information Service, Springfield, VA 22161 as NTIS Report PB-80 162 704.]

The Upper Eagle Valley Sanitation District and Vail Water Sanitation District have proposed the expansion and improvement of their respective wastewater facilities located at Avon and Vail, Colorado. The treatment capacities proposed by the two Districts are based on a per capita water use rate of 150 gallons per day. EPA believes that this figure is excessive for this area and will fund capacity to treat wastewater from the projected population at a rate of 135 gallons per day. EPA will provide Step II design funds for the proposed treatment facilities at these reduced capacities. The availability of Step III funds for construction of the improvements and expansions (at reduced size) of these wastewater treatment facilities will depend on whether two other conditions are met.

1170. U.S. Environmental Protection Agency, 1977, Water quality study, Grand Lake, Shadow Mountain Lake, Lake Granby, Colorado, 1974: U.S. Environmental Protection Agency Report EPA-908/2-77-002, 225 p. [Available from National Technical Information Service, Springfield, VA 22161 as NTIS Report PB-80 156 144.]

To develop additional information on the effect of point and non-point sources of wastes and on the trophic condition of three lakes, EPA conducted an investigation of Grand, Shadow Mountain, and Granby lakes. The study, conducted in June and repeated again in September, 1974, concentrated on (1) the determination of the existing nutrient level in each of the lakes; (2) the determination of the existing organic and nutrient loadings from point and non-point sources; and (3) the determination of the probable consequences of increased nutrient levels in the three lakes as regards nuisance algal growth. Sampling was conducted at 71 locations throughout the study area.

1171. U.S. Environmental Protection Agency, 1986, Superfund Enforcement Decision document (EPA Region 2) --Smuggler Mountain, Pitkin County, Colorado, September 1986: U.S. Environmental Protection Agency Report EPA/ROD/R02-86/037, 53 p. [Available from National Technical Information Service, Springfield, VA 22161 as NTIS Report PB-87 189 908.]

The Smuggler Mountain site is located immediately northeast of the City of Aspen in Pitkin County, Colorado. It comprises 110 acres of waste rock, tailings, and slag containing high levels of lead and cadmium. The mining wastes which characterize the site are the result of years of extensive mining, milling, and smelting operations. As a result, wastes are highly dispersed, and little is known about their disposition. Soil is the primary contaminated medium; however, contaminants have been detected in some ground and surface waters. The selected remedial action for the site is broken into distinct operable units. Operable Unit 1 - excavation and permanent onsite disposal of soils with lead above 5,000 ppm, including a RCRA multi-layer cap; soil 
capping of all areas with lead between 1,000 and 5,000 ppm lead; five-year ground water monitoring; and provision of a permanent alternate water supply for

5-7 residences. Operable Unit 2 -supplemental RI/FS, with possible ground water remediation and mine reclamation activities.

1172. U.S. Environmental Protection Agency, 1993, Superfund Record of Decision (EPA Region 8)-Eagle Mine Site, Operable Unit 1, Eagle County, Colorado, March 1993: U.S. Environmental Protection Agency Report EPA/ROD/R08-93/068, 91 p. [Available from National Technical Information Service, Springfield, VA 22161 as NTIS Report PB-94 964 416.]

This decision document presents the selected remedial action for the Eagle Mine Site, Operable Unit 1 (OU-1) (Site), located in Eagle County, Colorado. This Operable Unit, one of two designated for the Site, addresses the principal sources of mine waste pollution that are impacting the Eagle River and certain ground water resources. The purpose of this Operable Unit (OU-1) is to control the transport of toxic metals originating from various sources to the Eagle River and to Site ground waters. The identified sources include the Eagle Mine, the Roaster Pile area, the Waste Rock Piles, Rex Flats, the Old Tailings Pile (OTP), the Consolidated Tailings Pile (CTP), and the Maloit Park wetlands.

1173. U.S. Federal Highway Administration, 1979, Final environmental impact statement--Hotchkiss to Paonia Dam, Delta and Gunnison Counties, Colorado: Denver, Colo., U.S. Federal Highway Administration Report RS-133(5), 299 p.

1174. U.S. Federal Water Pollution Control Administration, 1950, Survey of sanitary facilities and pollution contributed to reservoirs and lakes of the Colorado-Big Thompson Project South Platte River District: Kansas City, Mo., Bureau of Reclamation, 35 p.

Results are presented of a survey made in August 1950 of sanitary facilities of Bureau of Reclamation installations and pollution contributed to reservoirs and lakes involved in the development of the Colorado-Big Thompson Project in order to observe sanitary defects and to make recommendations for their correction. Three general areas are considered: Lake Estes-Mary Lake, Shadow Mountain Lake-Granby Reservoir, and Green Mountain Lake.

1175. U.S. Federal Water Pollution Control Administration, 1966, Colorado River Basin Water Quality Control Project, program review, Denver, Colorado, April 25, 1966: Denver, Colo., U.S. Federal Water Pollution Control Administration, $146 \mathrm{p}$. [Available from National Technical Information Service, Springfield, VA 22161 as NTIS Report PB-260 047/6.]

The Colorado River Basin Water Quality Control Project is reviewed. The bulk of this report deals with activities and accomplishments for FY 1966, including: radiological pollution; mineral pollution; municipal, industrial and related water pollution problems; laboratory activities; and STORET activities. Departures from FY 1966 plans are reviewed along with plans and schedules for work proposed for FY 1967. Details are also offered on the budget justification, technical backup requirements, and organization and management. 
1176. U.S. Federal Water Pollution Control Administration, 1966, Disposition and control of uranium mill tailings piles in the Colorado River Basin: Denver, Colo., U.S. Federal Water Pollution Control Administration, 71 p. [Available from National Technical Information Service, Springfield, VA 22161 as NTIS Report PB-228 363/8.]

In addition to the more usual organic and inorganic liquid waste disposal problems encountered at many industrial installations, the uranium milling industry produces large quantities of solid wastes in the form of radioactivity laden sand tailings pile material. This report evaluates the radioactivity content of uranium mill tailings piles in the Colorado River Basin, evaluates their radioactivity water pollution potential insofar as this is possible, and on a case-by-case basis, indicates feasible and desirable remedial measures for controlling and limiting the spread of radioactivity from the piles.

1177. U.S. Federal Water Pollution Control Administration, 1966, Frequency analysis of specific water quality parameters for the Colorado River Basin: San Francisco, Calif., U.S. Federal Water Pollution Control Administration, 48 p. plus 514 p. appendix.

1178. U.S. Federal Water Pollution Control Administration, 1967, Briefing document on uranium mill tailings: San Francisco, Calif., U.S. Federal Water Pollution Control Administration, various pagination.

1179. U.S. Federal Water Pollution Control Administration, 1967, Conference in the matter of pollution of the interstate waters of the Colorado River and its tributaries (6th) session, Denver Law Center auditorium, Denver, Colorado, July 26, 1967, transcript of proceedings:

Washington, D.C., U.S. Federal Water Pollution Control Administration, 217 p. [Available from National Technical Information Service, Springfield, VA 22161 as NTIS Report PB-215 927.]

The purpose of the conference was to bring together the state water pollution control agencies, representatives of the United States Department of the Interior, and other interested parties to review the existing situation, the progress which has been made, to lay a basis for future action by all parties concerned, and to give the states, localities, and industries an opportunity to take any indicated remedial action under state and local law.

1180. U.S. Federal Water Pollution Control Administration, 1967, Immediate water pollution control needs for the interstate waters in the Colorado River Basin--Wyoming, Colorado, Utah, New Mexico, Nevada, Arizona, and California: San Francisco, Calif., U.S. Federal Water Pollution Control Administration, $59 \mathrm{p}$.

1181. U.S. Federal Water Pollution Control Administration, 1968, Biological studies of selected reaches and tributaries of the Colorado River: Cincinnati, Ohio, U.S. Federal Water Pollution Control Administration PR-15, 177 p. [Available from National Technical Information Service, Springfield, VA 22161 as NTIS Report PB-228 209/3.]

Biological studies were conducted in 1966 on 921 miles of the Colorado River system, including parts of the main stream and those tributaries that are interstate waters. These studies showed that wastes from municipalities, mining activities, and gravel operations seriously degraded the aquatic life inhabiting 83 miles of the interstate 
waters. Also studied were 581 miles of intrastate streams in the Colorado River system, of which 97 miles were seriously degraded for aquatic life by man's activities.

1182. U.S. Federal Water Pollution Control Administration, 1969, A report on pollution of the Upper Colorado River Basin: Cincinnati, Ohio, U.S. Federal Water Pollution Control Administration PR-16, 82 p. [Available from National Technical Information Service, Springfield, VA 22161 as NTIS Report PB-216 945.]

Water quality information is presented here for four geographical areas: the Upper Colorado River Main Stem, Price River system, Gunnison-Uncompahgre River systems, and the San Juan River system. Water quality characteristics examined were dissolved oxygen, coliform bacteria, Salmonella bacteria, specific conductance, and metals. Water uses considered were public water supply, water contact recreation, fish and aquatic life, and agricultural and industrial water supply.

1183. U.S. Federal Water Pollution Control Administration, 1969, A report on pollution of the Upper Colorado River Basin, technical appendix: Cincinnati, Ohio, U.S. Federal Water Pollution Control Administration PR-17, 98 p. [Available from National Technical Information Service, Springfield, VA 22161 as NTIS Report PB-216 218.]

The report includes all of the physical, chemical, and bacteriological data determined from analyses on samples collected during the Technical Advisory and Investigations Branch of the Federal Water Pollution Control Administration study of the Upper Colorado River during July and August, 1966 (see also PB-216 945).

1184. U.S. Federal Water Pollution Control Administration, 1969, Water quality evaluation of the Bluestone Project, Colorado: San Francisco, Calif., U.S. Federal Water Pollution Control Administration, 23 p. [Available from National Technical Information Service, Springfield, VA 22161 as NTIS Report PB-216 228.]

The water quality evaluation has been prepared for the Bureau of Reclamation, Region 4, U.S. Department of the Interior, Salt Lake City, Utah, for inclusion in their feasibility report for the Bluestone Reservoir Project, Colorado. The primary purposes of this evaluation are: to determine the need for and value of separable reservoir storage for streamflow regulation to control water quality; to assess the overall impact of the proposed development on water quality, both in and outside the project area; and to recommend, where applicable, water quality control measures for the project.

1185. U.S. Federal Water Pollution Control Administration, 1970, Cooperative salinity control reconnaissance study, Upper Colorado River Basin (final review draft): San Francisco, Calif., U.S. Federal Water Pollution Control Administration, 128 p. [Available from National Technical Information Service, Springfield, VA 22161 as NTIS Report PB-255 279/2.]

Contents: causes of salinity; effects of salinity on uses of water; technical possibilities for salinity control; status of salinity control activities in the Upper Colorado Basin; legal, institutional, and financial considerations. 
1186. U.S. Federal Water Pollution Control Administration and Bureau of Reclamation, 1970, Cooperative salinity control reconnaissance study--Upper Colorado River Basin: San Francisco, Calif., Salt Lake City, Utah, U.S. Federal Water Pollution Control Administration and Bureau of Reclamation, $119 \mathrm{p}$.

1187. U.S. Fish and Wildlife Service, 1950, Substantiating report for a special report on recreational use and water requirements of the Colorado River fishery below Granby Dam in relation to the Colorado-Big Thompson diversion project: Albuquerque, N. Mex., U.S. Fish and Wildlife Service, $150 \mathrm{p}$.

1188. U.S. Fish and Wildlife Service, 1987, Final environmental assessment--Recovery implementation program for endangered fish species in the Upper Colorado River Basin: Denver, Colo., U.S. Fish and Wildlife Service, various pagination.

1190. U.S. Fish and Wildlife Service, 1990, Bonytail chub recovery plan: Denver, Colo., U.S. Fish and Wildlife Service, $35 \mathrm{p}$.

1191. U.S. Fish and Wildlife Service, 1990, Humpback chub recovery plan: Denver, Colo., U.S. Fish and Wildlife Service, $43 \mathrm{p}$.

1192. U.S. Fish and Wildlife Service, 1991, Colorado squawfish recovery plan: Denver, Colo., U.S. Fish and Wildlife Service, $56 \mathrm{p}$.

1193. U.S. Fish and Wildlife Service, 1993, Critical habitat designations proposed for four Colorado River fishes: Endangered Species Technical Bulletin, v. 18, no. 2, p. 7-11.

1194. U.S. Fish and Wildlife Service, 1993, Overview of the proposed critical habitat designation for the four Colorado River endangered fishes, draft [part one of three-part series], economic overview: Salt Lake City, Utah, U.S. Fish and Wildlife Service, 65 p.

1195. U.S.Forest Service, 1982, Mount Emmons mining project, environmental impact statement, final: Washington, D.C., U.S. Department of Agriculture, Forest Service, 240 p.

1196. U.S. Geological Survey, 1907-1973, Surface water supply of the United States, 1907-1970, part 9, Colorado River Basin: U.S. Geological Survey Water-Supply Papers. [Published on a yearly basis except for 1907-1908, 1921-1922, 1961-1965, 1966-1970.]

1197. U.S. Geological Survey, 1917, Profile surveys in the Colorado River Basin in Wyoming, Utah, Colorado, and New Mexico: U.S. Geological Survey Water-Supply Paper 396, 6 p. plus 43 maps.

1199. U.S. Geological Survey, 1949, 1951, 1971, Index of surface-water records to September 30, 1970, part 9, Colorado River Basin: U.S. Geological Survey Circular 659, 55 p. [Also published in 1951 for surface-water records to September 30, 1950, Circular 140, 24 p.; 1949, surface-water records to Sept. 30, 1948, Circular 45, 20 p.]

1200. U.S. Geological Survey, 1954, 1964, Compilation of records of surface waters of the United States, October 1950 to September 1960, part 9, Colorado River Basin: U.S. Geological Survey Water-Supply Paper 1733, 586 p. [Also published in 1954 for records through September 1950, Water-Supply Paper 1313, 749 p.] 
1201. U.S. Geological Survey, 1954-1966, Quality of surface waters of the United States, 1950-1963, parts 9-14, Colorado River Basin to Pacific slope basins in Oregon and lower Columbia River Basin. Annual reports as follows: 1950, Water-Supply Paper 1189; 1951, Water-Supply Paper 1200; 1952, Water-Supply Paper 1253; 1953, Water-Supply Paper 1293; 1954, WaterSupply Paper 1353; 1955, Water-Supply Paper 1403; 1956, Water-Supply Paper 1453; 1957, Water-Supply Paper 1523; 1958, Water-Supply Paper 1574; 1959, Water-Supply Paper 1645; 1960, Water-Supply Paper 1745; 1961, Water-Supply Paper 1885; 1962, Water-Supply Paper 1945; 1963, Water-Supply Paper 1951.

1202. U.S. Geological Survey, 1962-1965, Surface-water records of Colorado, 1961-1964:

U.S. Geological Survey, various pagination (published annually).

1204. U.S. Geological Survey, 1965, Water quality records in Colorado, 1964: U.S. Geological Survey, $84 \mathrm{p}$.

1205. U.S. Geological Survey, 1966-1975, Water resources data for Colorado, 1965-1974--pt. 1, Surface-water records; pt. 2, Water-quality records: U.S. Geological Survey, variously paged. [Published annually on a water-year basis (October to September).]

1206. U.S. Geological Survey, 1968, Mineral and water resources of Colorado: Denver, Colo., Colorado Geological Survey Miscellaneous Information 7, 302 p.

1207. U.S. Geological Survey, 1969-1972, Quality of surface waters of the United States, 1964-1967, parts 9-11, Colorado River Basin to Pacific slope basins in California. Annual reports as follows: 1964, Water-Supply Paper 1958; 1965, Water-Supply Paper 1965; 1966, Water-Supply Paper 1995; 1967, Water-Supply Paper 2015.

1208. U.S. Geological Survey, 1971, Reported occurrences of selected minerals in Colorado: U.S. Geological Survey Mineral Investigations Resource Maps, Map MR-57, scale 1:500,000.

1209. U.S. Geological Survey, 1973, 1974, 1976, Quality of surface waters of the United States, 1970, parts 9 and 10, Colorado River Basin and the Great Basin: U.S. Geological Survey Water-Supply Paper 2158, 371 p. [Also published in 1974 for water year 1969, Water-Supply Paper 2148, 348 p.; 1973, for water year 1968, Water-Supply Paper 2098, 296 p.]

1210. U.S. Geological Survey, 1975, River basins of the United States--The Colorado: U.S. Geological Survey Information Leaflet INF-72-8 (R 2), 7 p.

1211. U.S. Geological Survey, 1977-1983, Water resources data, Colorado, water years 1975-1982, volume 2, Colorado River Basin: U.S. Geological Survey Water-Data Report, variously paged. [Published annually on a water-year basis (October to September). For water years 1975-1981, published as Water resources data for Colorado; for water year 1982, volume 2, Colorado River Basin above Dolores River.]

1212. U.S. Geological Survey, 1981, Catalog of information on water data--Index to water-data acquisition, Region 14, Upper Colorado, 1980: Reston, Va., U.S. Geological Survey, Office of Water Data Coordination, $157 \mathrm{p}$. 
1213. U.S. Geological Survey, 1984, Colorado water issues, in U.S. Geological Survey, National water summary 1983--Hydrologic events and issues: U.S. Geological Survey Water-Supply Paper 2250, p. 96-99.

1214. U.S. Geological Survey, 1992, Hydrologic unit map-1974, State of Colorado: U.S. Geological Survey, 1 sheet, scale 1:500,000.

1216. U.S. Geological Survey and Colorado Mining Industrial Development Board, 1968, Mineral and water resources of Colorado: Denver, Colo., U.S. Geological Survey, 802 p.

1217. U.S. Public Health Service, 1951, Colorado River drainage basin--A cooperative State-Federal report on water pollution: U.S. Public Health Service Water Pollut. Ser. 9, 46 p.

1218. U.S. Public Health Service, 1961, Review of action taken under the enforcement provisions of the Federal Water Pollution Control Act: Washington, D.C., U.S. Public Health Service, 26 p. [Available from National Technical Information Service, Springfield, VA 22161 as NTIS Report PB-260 199/5.]

Action under the enforcement provisions of the Federal Water Pollution Control Act is reviewed for the following areas: Animas River (Colorado-New Mexico), Bear River (Idaho, Utah, Wyoming), Big Blue River (Nebraska-Kansas), Colorado River and all tributaries, Lower Columbia River (Washington-Oregon), Corney Drainage System (Arkansas-Louisana), North Fork of Holston River (Virginia-Tennessee), Mississippi River (St. Louis metropolitan area), Missouri River (Kansas City, Omaha, St. Joseph, and Sioux City metropolitan areas), North Platte River (Nebraska-Wyoming). Potomac River (Washington, D.C. metropolitan area), and Raritan Bay (New JerseyNew York).

1219. U.S. Public Health Service, 1961, Stream surveys in vicinity of uranium mills, I, area of Grand Junction, Colorado, August 1960: Denver, Colo., U.S. Public Health Service, 23 p. [Available from National Technical Information Service, Springfield, VA 22161 as NTIS Report PB-260 276/1.]

The results of one of three short-term field studies conducted in the vicinity of uranium processing mills in western Colorado and eastern Utah are presented. The surveys were conducted to determine the pollutional constituents contained in uranium mill discharges and the effect of these discharges on receiving waters in areas of the Colorado River Basin.

1220. U.S. Public Health Service, 1962, River mileage tabulations for the Colorado River Basin-Communities and major tributaries: Denver, Colo., U.S. Public Health Service, 24 p. [Available from National Technical Information Service, Springfield, VA 22161 as NTIS Report PB-229 834/7.]

Summary of river mileage for major tributaries of the Colorado River Basin. 
1221. U.S. Public Health Service, 1962, Salinity investigations of Grand Valley and Gunnison River, 1962: Denver, Colo., U.S. Public Health Service, 41 p. [Available from National Technical Information Service, Springfield, VA 22161 as NTIS Report PB-260 255/5.]

The results of a two-phase survey of the water of the Colorado River in the Grand Valley area and of the water of the Gunnison River are presented. The first phase of the Grand Valley survey was conducted during the nonirrigation season and included the area from Cameo, Colorado, to below Moab, Utah; the second phase from Cameo downstream to Westwater, Utah. Flow data is reported, detailed information on total dissolved solids in the waters is given, and the relative significance of the sources causing the increase in total dissolved solids in these waters is evaluated.

1222. U.S. Public Health Service, 1962, State and county area tabulations for the Colorado River Basin: Denver, Colo., U.S. Public Health Service, 22 p. [Available from National Technical Information Service, Springfield, VA 22161 as NTIS Report PB-245 734/9.]

The report provides drainage area determinations which have been adopted as standard basic data for use in the Colorado River Basin Water Quality Control Project. A check of available data of this type prepared by various public and private agencies revealed slight variations among the various sources. The data contained in this report were developed, therefore, to avoid confusion that might arise if a standard set of these data were not specified for use in this project.

1223. U.S. Public Health Service, 1963, Annotated bibliography on the effects of irrigation practices on stream water quality with emphasis on salinity and pesticides: Denver, Colo., U.S. Public Health Service, $37 \mathrm{p}$.

Bibliography with annotations concerning the effects of irrigation practices on water quality downstream. Contains information on salinity in the Colorado River Basin.

1224. U.S. Public Health Service, 1963, Colorado River Basin Water Quality Control Project, program review, Washington, D.C., February 6-7, 1963: Denver, Colo., U.S. Public Health Service, 132 p. [Available from National Technical Information Service, Springfield, VA 22161 as NTIS Report PB-260 048/4.]

This is an interim program review of the Colorado River Basin Water Quality Control Project in progress. Organization and management of the project are presented. Accomplishments to date and work anticipated for the balance of the fiscal year with respect to each of the items are detailed in activity reports. Initially the principal emphasis of this project was placed on investigations related to pollution caused by uranium milling operations. Considerable engineering field work was devoted to this problem, and field activities were expanded to fill the requirements of the water quality management program and to examine existing nonradiological problem areas. These activities are described in detail. Salinity then became the most significant problem with respect to water quality of the Basin. At this point the project is estimated to be 35 percent completed. A bibliography of project reports and publications is included.

160 Bibliography, Indices, and Data Sources of Water-Related Studies, Upper Colorado River Basin, Colorado and Utah, 1872-1995 
1225. U.S. Public Health Service, 1963, Interstate conference on pollution of the Colorado River, technical discussion on accomplishments and future activities, held at Santa Fe, New Mexico on February 13-15, 1963: Denver, Colo., U.S. Public Health Service, 146 p. [Available from National Technical Information Service, Springfield, VA 22161 as NTIS Report PB-260 068/2.]

Topics covered at the third conference on pollution of the Colorado River include: radiological crop surveys; Lake Mead study; uranium mill effluents; Yuma situation; radiological dike construction criteria; alerting system; Monticello situation; Uravan surveys; Dolores-San Miguel Rivers Water Quality Study; radium monitoring network; and basinwide sediments. Emphasis is placed on the Water Quality Management Program development, including details on the economic base survey, hydrologic studies, historical USGS water quality data, and waste discharges.

1226. U.S. Public Health Service, 1963, Land ownership in the Colorado River Basin: Denver, Colo., U.S. Public Health Service, 21 p. [Available from National Technical Information Service, Springfield, VA 22161 as NTIS Report PB-229 689/5.]

In the early stages of the Colorado River Basin Water Quality Control Project, it was deemed necessary to classify all lands in the Colorado River Basin as to ownership and/or control. The information in the report provides an essential component in the analysis of the basin's water quantity and quality management problems. It will contribute to the development of the economic base study and the engineering studies which, of course, form the basis for development of the overall water quality management program underway for the Colorado River Basin.

1227. U.S. Public Health Service, 1963, Physical and chemical stratification in two high altitude reservoirs of the Colorado River Basin: Denver, Colo., U.S. Public Health Service PR-13, 48 p. [Available from National Technical Information Service, Springfield, VA 22161 as NTIS Report PB-260 160/7.]

The field investigations of August 1962 for Lake Granby and Taylor Park Reservoir were intended to provide general information on stratification phenomena in reservoirs of the Colorado River Basin, to aid in project evaluation of low-flow augmentation by proposed reservoirs in the Basin, and promote an understanding of methods of improving water quality downstream from these reservoirs. Data were collected for temperature, dissolved oxygen, 5-day BOD, conductivity, alkalinity, pH, Secchi Disk readings, and plankton enumeration of the main lake, and inflow and outflow waters. Radiological content of bottom lake muds was also determined. Statistical data and a bibliography are included.

1228. U.S. Public Health Service, 1963, Pollution of the interstate waters of the Colorado River and its tributaries, Proceedings of conference held at San Diego, California on May 27, 1963: Washington, D.C., U.S. Public Health Service, 94 p. [Available from National Technical Information Service, Springfield, VA 22161 as NTIS Report PB-229 734/9.]

The conference includes data on: water quality; sampling; warning systems and surveys on the matter of pollution of the interstate waters of the Colorado River and its tributaries for 1963. 
1229. U.S. Public Health Service, 1963, Radiological content of Colorado River Basin bottom sediments, August 1960-August 1961: U.S. Public Health Service Report PR-10, 62 p. [Available from National Technical Information Service, Springfield, VA 22161 as NTIS Report PB-260 216/7.]

Data on the radium content of bottom sediment material collected in 1960 and 1961 throughout the Colorado River Basin is provided. For the sediment surveys reported, 254 samples representing 121 different sampling stations were collected in locations where the sediment was not influenced by uranium mining and milling activity (background locations). Detailed tables of the results of radium-226, gross alpha, and gross beta determinations on the sediments collected are included.

1230. U.S. Public Health Service, 1963, The purpose and plan of an economic base survey of the Colorado River Basin: U.S. Public Health Service Report ER-2, 21 p. [Available from National Technical Information Service, Springfield, VA 22161 as NTIS Report PB-229 693/7.]

The economic base survey report of the Colorado River Basin provides an analysis of the economic characteristics, developments, and trends of the past, and a projection of future economic growth in view of the area's basic available resources. The economic base survey in turn provides the basis for development of a water quality management program for the study area.

1231. U.S. Public Health Service, 1963, Water resources study and public health aspects of the Dallas Creek Project, Colorado--Study of potential needs and value of storage of water for quality control purposes and the public health aspects of the project: Denver, Colo., U.S. Public Health Service, 71 p. [Available from National Technical Information Service, Springfield, VA 22161 as NTIS Report PB-217 450.]

General objectives of the study are to assess the probable effects the proposed project will have on water quality in local streams and reservoirs; to ascertain the benefits or harm resulting from changes in water quality; to assess the suitability of the water for proposed water uses, and to examine the need for regulation of streamflow for the purpose of water quality control. Need for streamflow regulation was studied not only in light of present conditions, but also under anticipated economic development in the Uncompahgre River Basin of the years 1985, 2010, and 2060. The report includes the results of insect vector control of the project. A preliminary evaluation of the insect vector problems that may be associated with the project is presented.

1232. U.S. Public Health Service, 1964, Colorado River Basin Water Quality Control Project, program review, Washington, D.C., January 20-21, 1964: Denver, Colo., U.S. Public Health Service, 175 p. [Available from National Technical Information Service, Springfield, VA 22161 as NTIS Report PB-260 049/2.]

Significant changes have been made in the long range goals and objectives of the Colorado River Basin Project on water quality control. The scope has been changed from the development of a comprehensive program to investigation of the critical and pressing interstate pollution problems which may exist now or in the future in the Basin. Salinity continues to be the major pollution problem. A surveillance program with respect to radiological pollution is being carried forward. These programs are detailed in activities reports. A pesticide investigation has been undertaken to gather

162 Bibliography, Indices, and Data Sources of Water-Related Studies, Upper Colorado Rlver Basin, Colorado and Utah, 1872-1995 
information on existing concentrations and loading of selected pesticides in the lower main stream. The significance of the findings are to be assessed with respect to municipal water use and effects on aquatic life. A limited number of herbicide analyses is included in the investigation. Future plans and organization are set forth.

1233. U.S. Public Health Service, 1964, Pollution of the interstate waters of the Colorado River and its tributaries, Proceedings of conference, session (5th) held at Las Vegas, Nevada, on May 26, 1964: Washington, D.C., U.S. Public Health Service, 271 p. [Available from National Technical Information Service, Springfield, VA 22161 as NTIS Report PB-229 718/2.]

The conference report includes data on: pollution sources; statements; projects and policies; interindustry transactions; costs of water and related information on the matter of pollution of the interstate waters of the Colorado River and its tributaries, between the states of Arizona, California, Colorado, Nevada, New Mexico, Utah, Wyoming, and the Department of Health, Education, and Welfare for 1964.

1234. U.S. Public Health Service, 1964, Water quality control study and public health aspects of the West Divide Project, Colorado--The study of potential needs and value of water for the purpose of water quality control and the public health aspects of the West Divide Project, Colorado: Denver, Colo., U.S. Public Health Service, 44 p. [Available from National Technical Information Service, Springfield, VA 22161 as NTIS Report PB-217 858.]

General objectives of the water quality control study are to assess the probable effects the proposed project will have on water quality in local streams and reservoirs; to ascertain the benefits or harm resulting from changes in water quality; to assess the suitability of the water for proposed water uses; and to examine the need for regulation of streamflow for the purpose of water quality control. The need for streamflow regulation was studied not only for the present conditions, but also for anticipated future conditions in the West Divide Project area for the years 1970, 1985, 2010 , and 2060. The report includes the results of a study of general public health aspects and insect vector control of the project. A preliminary evaluation of the insect vector problems that may be associated with the project is presented.

1235. U.S. Public Health Service, 1964, Water resources study and public health aspects of the West Divide Project: Denver, Colo., U.S. Public Health Service, 29 p. plus appendix.

1236. U.S. Public Health Service, 1965, A study of municipal, rural, domestic and livestock water requirements in the Colorado River Basin: Denver, Colo., U.S. Public Health Service, 40 p.

1237. U.S. Public Health Service, 1965, Colorado River Basin Project, program review, Denver, Colorado, April 7-8, 1965: Denver, Colo., U.S. Public Health Service, 136 p. [Available from National Technical Information Service, Springfield, VA 22161 as NTIS Report PB-260 045/0.]

The Colorado River Basin Water Quality Control Project is a pollution study concerned with (1) identification of pollution sources, (2) estimation of effects of pollution on legitimate water uses, and (3) development of feasible pollution controls. The project's engineering activities are directed toward the identification of pollution sources, assessment of damages due to pollution from salinity, and development of feasible control measures for all sources of salinity pollution, whether they be agricultural, municipal, industrial, or natural. The economic study projects the level 
and pattern of economic activity for the years 1965, 1980, and 2010 by means of interindustry input-output tables. This report covers the program content as well as its organization and management.

1238. U.S. Public Health Service, 1965, Colorado River Basin Project, technical session, Denver, Colorado, April 14-15, 1965: Denver, Colo., U.S. Public Health Service, 95 p. [Available from National Technical Information Service, Springfield, VA 22161 as NTIS Report PB-260 046/8.]

The fifth session of the conference on pollution of the interstate waters of the Colorado River and its tributaries (Colorado, Utah, Arizona, Nevada, California, New Mexico, Wyoming) is presented. This report reviews the content of the Colorado River Basin Project, including the long-range goals, stream measurement studies, special techniques, economic studies, pesticide usage, Lake Mead effects, legislation, and the work programs of field and pollution stations. Maps and charts are included.

1239. U.S. Public Health Service, 1965, Preliminary water pollution control study, Colorado River Basin above Hoover Dam; appendix A, review of developments, methods, costs and controls; A-1, evaporation; A-2, phreatophytes; A-3, desalination: Denver, Colo., U.S. Public Health Service, 47 p. [Available from National Technical Information Service, Springfield, VA 22161 as NTIS Report PB-260 153/2.]

The three appendices review the developments, methods, costs, and controls related to evaporation, phreatophytes, and desalination. Each of these areas is explored separately with their own bibliographies included. Evaporation is discussed in terms of the importance of evaporation losses, types of control, area reduction, mechanical covers, surface films, the history of films, and U.S. evaporation control studies. Past and present interest in phreatophytes and their use of water is discussed in some detail. It is concluded that the future of saline water conversion in providing high quality will be limited to the area of water treatment and is not likely to be used as a salinity control procedure for maintaining in-stream water quality.

1240. U.S. Public Health Service, 1965, Water quality control study and public health aspects of the Battlement Mesa Project: Denver, Colo., U.S. Public Health Service, 40 p. [Available from National Technical Information Service, Springfield, VA 22161 as NTIS Report PB-230 503.]

General objectives of the study were to assess the probable effects of the proposed project on water quality in local streams and reservoirs; to ascertain the benefits of harm resulting from changes in water quality; to assess the suitability of the water for proposed water uses; and to determine the need for and value of storage for regulation of stream flow for the purpose of water quality control. The study covers Mesa County in west central Colorado. The need for streamflow regulation was studied not only for the existing conditions, but also for anticipated future conditions in the years $1980,2000,2030$, and 2060.

1241. U.S. Public Health Service, 1969, Evaluation of radon 222 near uranium tailing pilings: U.S. Public Health Service Report DER 69-1, 67 p. 
1242. U.S. Public Health Service, 1970, Radium Monitoring Network, data release number 16: Denver Colo., U.S. Public Health Service, 32 p. [Available from National Technical Information Service, Springfield, VA 22161 as NTIS Report PB-260 231/6. Reports for data release numbers 1-15, 1962-1969, are also available from the National Technical Information Service.]

This sixteenth data release report provides radium-226 and uranium sampling results that supplement data from 15 previous reports dated October 1962 through July 1969. The tabular data indicated evidence of radium and uranium below recommended concentration levels from analysis of composite water samples at stations of the Radium Monitoring Network of the Colorado River Basin Water Quality Control Project. The network is a surveillance system consisting of continuous surface water sampling at 27 locations throughout the basin. It assays the radiological content of river water over the entire basin.

1243. U.S. Water Resources Council, 1977, Nationwide Analysis, Federal implications workshop reports, Region 14, Upper Colorado region: Washington, D.C., U.S. Water Resources Council, 34 p. [Available from National Technical Information Service, Springfield, VA 22161 as NTIS Report PB-80 110 588.]

The Nationwide Analysis was conducted by the Water Resources Council's member agencies and reflects their viewpoints about the existing and future water and related land requirements. This report summarizes the findings of a WRC sponsored workshop for the Upper Colorado region in late 1975.

1244. U.S. Water Resources Council, 1978, The Nation's water resources; the Second National Water Assessment, 14, Upper Colorado region: Washington, D.C., U.S. Water Resources Council, 81 p.

A summary of water use in the Upper Colorado region (comprised of portions of Arizona, New Mexico, Utah, Wyoming, Colorado, and Idaho) is provided, with a projection of water availability, quality, and use through the year 2000 . The primary source of water for the region is the Colorado River and its tributaries, which provide water for agriculture, energy, mining interests, and recreation. Consumption of water is projected to increase by 32 percent by 2000 . To solve the problems associated with increased demand, comprehensive Federal water projects should be instituted in the near future.

1245. U.S. Water Resources Council, 1981, Synthetic fuels development in the Upper Colorado region--Section 13(a), water assessment report (technical report): Washington, D.C., U.S. Water Resources Council, 138 p. [Available from National Technical Information Service, Springfield, VA 22161 as NTIS Report PB-82 156 761.]

The following general conclusions and major specific findings were reached during the course of the water assessment for the Upper Colorado region. The production of synthetic fuels in the Upper Colorado River region by the extraction and processing of oil shale and/or coal will require significant quantities of water. The overall supply of ground and surface water resources in the region is sufficient to accommodate a synfuels production level of nearly 3 million barrels oil equivalent per day. While the gross water supplies in the region are sufficient for accelerated synfuels development, water supply problems are apparent in some areas. 
1246. Udis, Bernard, ed., 1967, An analysis of the economy of the Upper Main Stem subbasin of the Colorado River drainage basin in 1960 with emphasis on the heavy water-using industries: Boulder, Colo., University of Colorado, 220 p. [Report to U.S. Federal Water Pollution Control Administration.]

1247. Udis, Bernard, ed., 1968, An interindustry analysis of the Colorado River Basin in 1960, with projections to 1980 and 2010: Boulder, Colo., University of Colorado, 249 p. plus two appendices. [Final report to U.S. Federal Water Pollution Control Administration.]

1248. Udis, Bernard, Howe, C.W., and Kreider, J.F., 1973, The interrelationship of economic development and environmental quality in the Upper Colorado River Basin--An interindustry analysis (research report): Boulder, Colo., University of Colorado EDA/OER-73-122, 651 p. [Available from National Technical Information Service, Springfield, VA 22161 as NTIS Report COM-73 $11970 / 3$.

A set of compatible models relating the economic activities of the sub-basins of the Upper Colorado River, both present and prospective, to air quality and water quantity and quality resulting from those patterns of economic activity is developed. The purpose of such a set of models is to enable the planner to test some of the environmental implications of alternative growth patterns for the region. The report describes in detail the models which have been developed and calibrated for the three upper sub-basins (the Upper Main Stem, the Green, and the San Juan), an area which contains the origins of the most pressing problems of the basin; salinity, shale oil industry, and the expanding diversions of water of the Rocky Mountain Eastern Slope.

1249. Udis, Bernard, Howe, C.W., Kreider, J.F., and Auger, Camilla, 1976, Socio-economic and environmental interactions in the Upper Main Stem sub-basin of the Colorado River BasinThree alternative energy development futures: Washington, D.C., Economic Development Administration EDA/OER-77/008, 213 p. [Available from National Technical Information Service, Springfield, VA 22161 as NTIS Report PB-266 082/7.]

In July 1973 the Bureau of Economic Research at the University of Colorado submitted a report to the Economic Development Administration entitled "The Interrelationship of Economic Development and Environmental Quality in the Upper Colorado River Basin: An Interindustry Analysis' (NTIS: COM-73-11970,642 pp.). That study presented a series of economic and environmental models applicable to the three upper regions or sub-basins of the Colorado River Basin: the Upper Main Stem, the Green River, and the San Juan. The work was inter-disciplinary in nature involving the joint efforts of economists and engineers. Since late 1973 the same research team (expanded to include sociologists) has been engaged in an effort to apply those models to a specific case of energy-related development in an effort to determine the direct and indirect economic and environmental consequences. Underground coal development in western Colorado was the case selected for the study with particular emphasis upon a region along the North Fork of the Gunnison River in Delta and Gunnison counties in western Colorado. This is the report from that study and includes the aspects of employment analysis, and socio-economic, hydrologic, and air quality assessments of the impact region under alternative development scenarios. 
1250. Ugland, R.C., Cochran, B.J., Hiner, M.M., Kretschman, R.G., Wilson, E.A., and Bennett, J.D., 1991, Water resources data, Colorado, water year 1990--v. 2, Colorado River Basin:

U.S. Geological Survey Water-Data Report CO-90-2, 394 p.

1251. Ugland, R.C., Cochran, B.J., Hiner, M.M., and Wilson, E.A., 1994, Water resources data, Colorado, water year 1993--v. 2, Colorado River Basin: U.S. Geological Survey Water-Data Report CO-93-2, 394 p.

1252. Ugland, R.C., Cochran, B.J., Hiner, M.M., Wilson, E.A., Bennett, J.D., and Jenkins, R.A., 1992-1993, Water resources data, Colorado, water years 1991-92--v. 2, Colorado River Basin: U.S. Geological Survey Water-Data Report CO-91-2, 416 p.; CO-92-2, 406 p.

1253. Ugland, R.C., Cochran, B.J., Kretschman, R.G., Wilson, E.A., and Bennett, J.D., 1989-1990, Water resources data, Colorado, water years 1988-89--v. 2, Colorado River Basin: U.S. Geological Survey Water-Data Report CO-88-2, 370 p.; CO-89-2, 402 p.

1254. Ugland, R.C., Duncan, A.C., Kretschman, R.G., and Ebling, J.L., 1985, Water resources data, Colorado, water year 1985--v. 2, Colorado River Basin: U.S. Geological Survey Water-Data Report CO-85-2, $239 \mathrm{p}$.

1255. Ugland, R.C., Kretschman, R.G., Wilson, E.A., and Bennett, J.D., 1988, Water resources data, Colorado, water year 1987--v. 2, Colorado River Basin: U.S. Geological Survey Water-Data Report CO-87-2, 394 p.

1256. Ugland, R.C., Steinheimer, J.T., Blattner, J.L., and Kretschman, R.G., 1984, Water resources data, Colorado, water year 1983--v. 2, Colorado River Basin above Dolores River: U.S. Geological Survey Water-Data Report CO-83-2, 287 p.

1257. Ugland, R.C., Steinheimer, J.T., Kretschman, R.G., and Wilson, E.A., 1987, Water resources data, Colorado, water year 1986--v. 2, Colorado River Basin: U.S. Geological Survey Water-Data Report CO-86-2, 434 p.

1258. University of Arizona, 1978, EPRI Water Supply Data Base System, final report, December 1978: Tucson, Ariz., University of Arizona, 121 p. [Available from National Technical Information Service, Springfield, VA 22161 as NTIS Report EPRI-EA-790.]

This is the final report for RP762, Water Supply Data Base for R and D Planning. The result of this study is the EPRI water data system - a data base or data dictionary, that describes water data collection efforts. The system has two components: (1) a macro data base that contains overview information about regions, organizations, and data sets and their interrelationships, and (2) a micro data base that contains the detailed structure of each data set, information about each set, and method of accessibility. This EPRI research effort is focused on national and regional data sets that provide information about the Colorado River Basin. These data bases are now installed on a commercial computer that is accessible through a national communication network. 
1259. University of Colorado, 1973, Salinity in water resources: Bureau of Reclamation Report OWRT-X-137(9081), 178 p. [Available from National Technical Information Service, Springfield, VA 22161 as NTIS Report PB-244 856/1.]

Current approaches to salinity control in the Colorado River are reviewed. New concepts regarding greatly increased irrigation efficiencies approaching one hundred percent are given. A model is described capable of evaluating water quantity and quality resulting from management strategies of an integrated stream-aquifer system. An optimizing model for timing, quantity, and quality of irrigation applications is described. A review of methods for measuring agricultural damages from salinity is presented, emphasizing farm management techniques to deal with increasing salinity. Damage to urban water systems is studied. The importance and types of economic incentives needed to induce water conservation and salinity reducing measures are studied, with recommendations for a water rights purchase program to reduce salinity and facilitate water transfers. The importance of cost-sharing arrangements to the selection of least-cost abatement programs is reviewed. The importance of spotting bottleneck gaps in knowledge and directing research to those issues is emphasized.

1260. Upper Colorado Region State-Federal Inter-Agency Group, 1971, Upper Colorado region comprehensive framework study, appendix IX, flood control: Upper Colorado Region StateFederal Inter-Agency Group, 110 p. [Available from National Technical Information Service, Springfield, VA 22161 as NTIS Report AD-A043 991/9.]

The Flood Control Work Group finds that flood problems exist in the Upper Colorado region and that substantial damage can be expected in the future unless adequate damage reduction programs are implemented. It is estimated that the total average annual flood damage in 1965 was $\$ 2.8$ million, and in the absence of additional damage reduction measures the flood damage will increase to $\$ 4.2$ million by 1980 , $\$ 6.8$ million by 2000 , and $\$ 10.6$ million by 2020 . The future flood damage reduction program consists of non-structural flood plain management measures, utilization of proposed multiple-purpose reservoirs for flood control storage, and construction of other structural flood control works where required. Flood control storage in multiple-purpose reservoirs and small flood retarding structures would amount to $2,300,000$ acre-feet. It is estimated the program presented would reduce the projected average annual flood damage to $\$ 3.3$ million by $1980, \$ 3.4$ million by 2000 , and $\$ 3.8$ million by 2020 . The damage projections are based on a modification of the OBERS baseline projections referred to as the Regional Interpretation of OBERS (RI-OBERS).

1261. Upper Colorado Region State-Federal Inter-Agency Group, 1971, Upper Colorado region comprehensive framework study, appendix XVIII, general program and alternatives: Upper Colorado Region State-Federal Inter-Agency Group, 203 p. [Available from National Technical Information Service, Springfield, VA 22161 as NTIS Report AD-A043 992/7.]

This document presents the results of comprehensive investigations for formulation of framework plans to provide a broad guide to the best use, or combination of uses, of water and related land resources to meet foreseeable needs. It provides appraisals of natural resources and their geographic distribution, projections of future requirements, associated problems and needs, and presents a framework program and alternatives to serve as a general guide for resource development and conservation to 
the year 2020, with intermediate objectives to the years 1980 and 2000 . The proposed levels of development meet the requirements of OBERS projections and use the available resources of the region in varying degrees. Water in the region, as in all semiarid areas, is the limiting criterion. However, it appears that the commitments of the Colorado River Compact can be met and, except for some water deficiency for fish and wildlife uses in Arizona and New Mexico and local shortage during low stream flows, on-site demands can be met for the 6.5 MAF development level. At higher levels, augmentation will be required. Costs have been estimated only for the framework plan. Installation and annual operation, maintenance, and replacement (OM and R) costs for water related and associated development for the 1966-80, 1981-2000, and 2001-2020 time frames are shown.

1262. Upper Colorado Region State-Federal Inter-Agency Group, 1971, Upper Colorado region comprehensive framework study: Upper Colorado Region State-Federal Inter-Agency Group, 136 p. [Available from National Technical Information Service, Springfield, VA 22161 as NTIS Report AD-A043 990/1.]

This report summarizes the results of comprehensive investigations for the formulation of proposed plans to provide a broad guide to the best use, or combination of uses, of water and related land resources to meet foreseeable needs. It provides appraisals of natural resources and their geographic distribution, makes projections of future requirements, defines problems and needs, and presents a framework program and alternatives thereto to serve as a general guide for resource development and conservation for the years 1980, 2000, and 2020. The 1965 level of water and related land utilization, management, and development was used as the base year for planning. The total water supply, which assumes no depletions by man's activities, averages 14.87 million acre-feet annually based upon the period 1914-1965. On-site depletions plus the evaporation from reservoirs on the main stem of the Colorado River for 1965 normalized conditions accounted for 62 percent of the 1965 use, main-stem reservoir evaporation 19 percent, export to adjacent regions 15 percent, and the remaining 4 percent was used for all other purposes.

1263. Upper Colorado River Basin Compact Commission, 1948, Upper Colorado River Basin Compact: Santa Fe, N. Mex., Upper Colorado River Basin Compact Commission, 28 p.

1264. Upper Colorado River Commission, 1993, Forty-fifth annual report of the Upper Colorado River Commission: Salt Lake City, Utah, Upper Colorado River Commission, 99 p. [Also published are annual reports volumes 1 through 44, 1947-1992.]

The Upper Colorado River Commission includes representatives from Colorado, New Mexico, Utah, Wyoming, and the federal government. The annual transcripts report on water use and delivery, water storage, flood control, agricultural and industrial development.

1265. Upper Gunnison River Water Conservancy District, 1994, Upper East River Basin winter water quality monitoring program: Gunnison, Colo., Upper Colorado River Water Conservancy District.

1266. URS Corporation, 1981, Problem identification and quantification, salinity investigation of Glenwood Springs-Dotsero unit: Denver, Colo., URS Corporation, 98 p. 
1267. Utah Environmental and Agricultural Consultants, 1973, Environmental setting, impact, mitigation and recommendations for a proposed oil products line between Lisbon Valley, Utah, and Parachute Creek, Colorado, part 1: Denver, Colo., Atlantic Richfield Company.

1268. Utah Water Research Laboratory, 1975, Colorado River regional assessment study; part 1, executive summary, basin profile, and report digest; part 2, detailed analyses; narrative description, data, methodology, and documentation; part 3, area-specific water quality analysis and environmental assessment; part 4, bibliography and appendices: Logan, Utah, Utah Water Research Laboratory.

1269. Utah Water Research Laboratory, 1975, Water Pollution Control Act of 1972, regional impacts, Colorado River Basin (final report): Washington, D.C., National Commission on Water Quality NCWQ-75/33, 1412 p. [Available from National Technical Information Service, Springfield, VA 22161 as NTIS Report PB-249 660/2.]

Environmental, economic, social, and institutional impacts of the Federal Water Pollution Control Act Amendments of 1972 (PL 92-500) on the Colorado River Basin are reviewed. Salinity, the most critical water quality problem in the basin, will be only slightly reduced by the NPDES permit program set up by the Act. A basin-wide program of irrigation efficiency will reduce the 9.0 million tons of salt carried by the river annually by 2.2 million tons. Total capital costs (in 1973 dollars) will be $\$ 160$ million to achieve the Act's 1977 requirement of best practicable treatment technology, with an additional $\$ 35$ million to achieve best available technology by 1983.

1270. Valdez, R., Mangan, P., Smith, R., and Nilson, B., 1982, Upper Colorado River investigation (Rifle, Colorado to Lake Powell, Utah, in Miller, W.H., and others, eds., Colorado River Fishery Project, final report, part two, field studies: Salt Lake City, Utah, U.S. Fish and Wildlife Service and Bureau of Reclamation, p. 101-279.

1271. Valdez, R.A., and Clemmer, G.H., 1982, Life history and prospects for recovery of the humpback chub and bonytail chub, in Miller, W.H., Tyus, H.M., and Carlson, C.A., eds., Fishes of the Upper Colorado River system--Present and future: Bethesda, Md., Western Division of the American Fisheries Society, p. 109-119.

1272. Valdez, R.A., Holden, P.B., and Hardy, T.B., 1990, Habitat suitability index curves for humpback chub of the Upper Colorado River Basin: Rivers, v. 1, p. 31-42.

1273. Valdez, R.A., and Wick, E.J., 1983, Natural vs. manmade backwaters as native fish habitat, in Adams, V.D., and Lamarra, V.A., eds., Aquatic resources management of the Colorado River ecosystem, proceedings of the 1981 symposium, Las Vegas, Nevada, November 16-18, 1981: Ann Arbor, Mich., Ann Arbor Science Publishers, p. 519-536.

1274. Vanderwilt, J.W., 1947, Mineral resources of Colorado: Denver, Colo., State of Colorado Mineral Resources Board, 547 p. 
1275. Vandivere, W.B., and Vorster, P., 1984, Hydrology analysis of the Colorado River floods of 1983 : GeoJournal, v. 9, no. 4, p. 343-350.

Despite an extensive system of river regulation works, the mainstream of the Colorado River in 1983 experienced the highest flows on record, resulting in severe flood damage. The efficacy of runoff and inflow prediction methodologies utilized to formulate reservoir operational responses during the winter and spring of 1983 is evaluated. Given the restrictions inherent in the forecasting network, the reservoir release schedule followed during the period by the US Bureau of Reclamation (USBR) is then reviewed. Two alternative reservoir release schedules are presented, and their hypothetical impacts on flooding assessed. In light of the 1983 flooding, recommendations are made to increase the reliability of flood predictions for Colorado River reservoirs and to reduce the extent of future damage to and destabilization of the biological and physical resources of Grand Canyon National Park. A brief epilogue provides an update on new policies which helped to attenuate 1984 peak reservoir discharges.

1277. Verdin, J.P., Hall, L., Halls, J., and Davidson, P., 1988, Application of remote sensing and GIS to estimate irrigation water use in the Upper Gunnison River Basin in Colorado, in Waterstone, M., and Burt, R.J., eds., Proceedings of the symposium on water-use data for water resources management: Bethesda, Md., American Water Resources Association Technical Publication Series TPS-88-2, p. 681-689.

1278. Vincent, J.R., and Russell, J.D., 1971, Alternatives for salinity management in the Colorado River Basin: Water Resources Research, v. 7, no. 4, p. 856-866.

Five basic alternatives for coping with the problem are presented and evaluated. Total costs associated with any given alternative, or the given salinity resulting, are the sum of salinity detriments plus the cost of constructing salt discharge control works. The impacts upon basin economy and Colorado River water quality for each alternative are presented and related to questions of equity.

1279. Voegeli, P.T., Sr., 1963, Water for the proposed west side (Harbison Meadow) campground site, Rocky Mountain National Park, Colorado: U.S. Geological Survey Open-File Report, 22 p.

1280. Voegeli, P.T., Sr., comp., 1964, Colorado ground-water reports: U.S. Geological Survey OpenFile Report, 28 p.

1281. Voegeli, P.T., Sr., 1965, Ground-water resources of North Park and Middle Park, Colorado-A reconnaissance: U.S. Geological Survey Water-Supply Paper 1809-G, 54 p.

1282. Voegeli, P.T., Sr., 1969, Geology and hydrology of the Project Rulison exploratory hole, Garfield County, Colorado: U.S. Geological Survey Open-File Report, 17 p. (Rulison-1.)

1283. Voegeli, P.T., Sr., and Claassen, H.C., 1971, Radiochemical analyses of water from selected streams, wells, springs and precipitation collected prior to reentry drilling, Project Rulison: U.S. Geological Survey Open-File Report 71-312, 15 p.

1284. Voegeli, P.T., Sr., and King, R.U., 1969, Occurrence and distribution of molybdenum in the surface water of Colorado: U.S. Geological Survey Water-Supply Paper 1535-N, 32 p. 
1285. Voegeli, P.T., Sr., West, S.W., and Cordes, E.H., 1970, Geohydrology-Project Rulison, Garfield County, Colorado: U.S. Geological Survey Open-File Report, 52 p. (Rulison-5.)

1286. Vranesh, G., and Cope, J.A., 1977, Water for oil shale development in western Colorado, a legal update, 1977: Oil shale symposium, tenth, Golden, Colo., April 21-22, 1977, Proceedings, p. 34-44.

1287. Wahl, K.L., 1993, Variation of Froude number with discharge for large-gradient streams, in Shen, H.W., Su, S.T., and Wen, F., eds., Hydraulic engineering '93, Proceedings of the 1993 conference, San Francisco, California, July 25-30, 1993: New York, N.Y., American Society of Civil Engineers, p. 1517-1522.

1288. Wahl, K.L., Collins, D.L., and Aldridge, B.N., 1987, Runoff in the Upper Colorado River Basin, water years 1983-85, and comparisons with forecasts of runoff to Lake Powell, Proceedings of the Western Snow Conference, 55th annual meeting, Vancouver, British Columbia, Canada, April 14-16, 1987: Portland, Oreg., Western Snow Conference, p. 31-40.

1289. Walker, W.R., 1970, Hydro-salinity model of the Grand Valley: Fort Collins, Colo., Colorado State University, Master's thesis, $94 \mathrm{p}$.

The contribution to the salt load of the Colorado River as it passes through the Grand Valley in Colorado is the most significant increase in the upper basin. Seepage and deep percolation losses enter shallow saline aquifers, resulting from interaction with salt deposits in the underlying Mancos Shale formation. This study produced a model of the groundwater, hydrology, and salinity in the Grand Valley.

1290. Walker, W.R., 1976, Integrating desalination and agricultural salinity control technologies: International Salinity Conference, Texas Tech University, Lubbock, Texas, August 16-20, 1976, Proceedings, p. 71-94.

1291. Walker, W.R., 1978, Integrating desalination and agricultural salinity control alternatives: Ada, Okla., Robert S. Kerr Environmental Research Laboratory EPA/600/2-78/074, 194 p. [Available from National Technical Information Service, Springfield, VA 22161 as NTIS Report PB-281 381.]

The cost-effectiveness relationships for various agricultural and desalination alternatives for controlling salinity in irrigation return flows are developed. Selection of optimal salinity management strategies on a river basin scale is described as a problem of integrating optimal strategies with individual subbasins and irrigated valleys. Desalination systems include seven processes: (1) multi-stage distillation; (2) vertical tube evaporation in conjunction with (1); (3) a vapor compression form of (2); (4) electrodialysis; (5) reverse osmosis; (6) vacuum freezing-vapor-compression; and (7) ion exchange. Agricultural salinity control alternatives include conveyance linings, irrigation scheduling, automation, sprinkler irrigation systems, and trickle irrigation systems. A case study of the Grand Valley in western Colorado is presented to demonstrate the analysis developed. 
1292. Walker, W.R., and Kroeker, B.E., 1982, Nitrates in groundwater resulting from manure applications to irrigated croplands: Ada, Okla., Robert S. Kerr Environmental Research Laboratory EPA-600/2-82-079, 94 p. [Available from National Technical Information Service, Springfield, VA 22161 as NTIS Report PB-82 255 415.]

Field data were collected from experimental plots located near Grand Junction, Colorado. Data collections were designed to provide a sufficiently broad range of conditions such that a simulation model could be verified. The experimental plots were planted to corn and were furrow irrigated. The basic management practices investigated were irrigation frequency, irrigation efficiency, and manure loading rate. Climatological conditions, soil moisture, potential evapotranspiration, and irrigation system performance were measured in the field. Soil samples and percolation water collected immediately beneath the crop root zone were analyzed for various nitrogen species, total organic carbon, and salinity cations and anions. Model simulations were run for a wide range of typical Grand Junction conditions to evaluate the effect of irrigation and animal manure utilization practices on nitrate movement to groundwater.

1293. Walker, W.R., and Skogerboe, G.V., 1971, Agricultural land use in the Grand Valley: Fort Collins, Colo., Colorado State University AER 71-72 WRW-GVS1.

1294. Walker, W.R., Skogerboe, G.V., and Evans, R.G., 1977, Development of best management practices for salinity control in Grand Valley, in Proceedings of national conference on irrigation return flow quality management, Fort Collins, Colorado, May 16-19, 1977: Fort Collins, Colo., Colorado State University, p. 385-393.

1295. Walker, W.R., Skogerboe, G.V., and Evans, R.G., 1978, 'Best Management Practices' for salinity control in Grand Valley: Ada, Okla., Robert S. Kerr Environmental Research Laboratory EPA600/2-78-162, 128 p. [Available from National Technical Information Service, Springfield, VA 22161 as NTIS Report PB-286 512.]

A nontechnical summary of several research activities in the Grand Valley is given. Analyses of alternative measures of reducing the salt load originating from the Valley as a result of irrigation return flows are presented. These alternatives include conveyance channel linings, field relief drainage, on-farm improvements (such as irrigation scheduling, head ditch linings, sprinkler and trickle irrigation), economic control measures such as taxation and land retirement, modified legal constraints, and collection and treatment of return flows with desalting systems. The best management practices for salinity control in the Grand Valley should be primarily the structural rehabilitation and operational modification of the local irrigation canal systems. Canal linings appear in the optimal strategies at higher levels of valley-wide salinity control emphasis but only so far as lining the Government Highline Canal is concerned. Desalting would become a cost-effective alternative after major irrigation system improvements are implemented.

1296. Walker, W.R., Skogerboe, G.V., and Evans, R.G., 1979, Developing best management practices for salinity control in Grand Valley, Colorado: Water Resources Research, v. 15, no. 5, p. 1073-1080. 
1297. Walker, W.R., Skogerboe, G.V., Evans, R.G., and Smith, S.W., 1977, The hydro-salinity system in the Grand Valley, in Proceedings of national conference on irrigation return flow quality management, Fort Collins, Colorado, May 16-19, 1977: Fort Collins, Colo., Colorado State University, p. 361-367.

1298. Wallis, J.R., 1982, Hydrologic problems associated with oil shale development, in Rinaldi, S., ed., Environmental systems analysis and management: Amsterdam, The Netherlands, NorthHolland Publishing Company, p. 85-102.

1299. Walton, G.E., 1883, Mineral springs of the United States and Canada: Philadelphia, Pa., D. Appleton and Company, 305 p.

1300. Wang, D.C., and Salas, J.C., 1991, Forecasting streamflow for Colorado River systems: U.S. Geological Survey G-1551-01, 228 p. [Available from National Technical Information Service, Springfield, VA 22161 as NTIS Report PB-93 190 775/XAB]

Forecasting water supply is critical for meeting growing demands for in state use of Colorado's water resources. The intensifying out of state demands for water originating in the State of Colorado underscore the necessity for maximizing beneficial use of water within the state. The State of Colorado has 16 compacts related to water use with other states; thus, Colorado's problem in this regard is on how to make the maximum use of our water resources while complying with compacts with other states. In this study, single input-single output and multiple input-single output periodic transfer models have been developed for forecasting monthly streamflow. First, the monthly streamflow is deseasonalized and filtered by a periodic autoregressive (PAR) model. Then, a transfer function model, in which the deseasonalized snow water equivalent is the input, and the streamflow residual from the PAR model is the output, was formulated. The building of the transfer function model has been carried out by using spectral analysis and the nonlinear least squares method was used for parameter estimation. The models have been applied to forecast monthly flows of the Rio Grande watershed system in Southern Colorado. Tests and comparisons of the proposed forecast method were made versus multiple regression approaches currently used by agencies responsible for managing Colorado water resources. It was shown that the single input-single output periodic transfer function model gives better monthly streamflow forecasts than the multiple regression approach. Likewise, the addition of more inputs in the transfer function model improves the forecasts. It is concluded that the forecasting approaches developed in this research may be useful for forecasting monthly flows in the Rio Grande system. It is expected that similar results would be obtained for other river systems in the state.

1301. Ward, J.C., Margheim, G.A., and Lof, G.O., 1971, Water pollution potential of spent oil shale residues: U.S. Environmental Protection Agency Water Pollution Control Research Series 14030 EDB $12 / 71,116 \mathrm{p}$.

1302. Ward, J.C., and Reinecke, S.E., 1972, Water pollution potential of snowfall on spent oil shale residues: Fort Collins, Colo., Colorado State University, 68 p. [Available from National Technical Information Service, Springfield, VA 22161 as NTIS Report PB-210 930. Also published through U.S. Bureau of Mines, Laramie, Wyo., 53 p.]

174 Bibllography, Indices, and Data Sources of Water-Related Studies, Upper Colorado River Basin, Colorado and Utah, 1872-1995 
1303. Ward, J.V., 1984, Stream regulation of the Upper Colorado River, channel configuration and thermal heterogeneity, in Congress of the International Association of Limnology, 22d, Lyon, France, Aug. 21, 1983: Proceedings International Association of Theoretical and Applied Limnology, p. 1862-1866.

A deep-release dam and transmountain diversion scheme altered downstream hydrological and thermal conditions and the biotic communities in a rhithron reach of the Upper Colorado River. Regulated discharge averaged only $11 \%$ of the historical flow, and natural thermal fluctuations were reduced. In summer epilithic algae and mosses covered virtually all rock surfaces. Macroinvertebrate density and biomass values were high compared to unregulated rhithron reaches at this elevation. Although community structure was altered and Shannon-Weaver diversity was somewhat depressed, it is postulated that shallow side channels are thermal refugia for species that require a wider range of temperatures to complete development than the temperatures prevailing in the main channel.

1304. Ward, J.V., 1987, Trichoptera of regulated Rocky Mountain streams: Series Entomologica, v. 39, p. $375-380$.

1305. Ward, J.V., and Holsinger, J.R., 1981, Distribution and habitat diversity of subterranean amphipods in the Rocky Mountains of Colorado: International Journal of Speleology, v. 11, p. 63-70.

1306. Ward, J.V., and Kondratieff, B.C., 1992, An illustrated guide to mountain stream insects of Colorado: Niwot, Colo., University Press of Colorado, $191 \mathrm{p}$.

1307. Ward, J.V., and Stanford, J.A., 1990, Ephemeroptera of the Gunnison River, Colorado, USA, in Campbell, J.C., ed., Mayflies and stoneflies--Life histories and biology, Proceedings of the 5th international Ephemeroptera conference and the 9th international Plecoptera conference, 1987, Marysville, Vic.: Boston, Mass., Kluwer Academic Publishers, p. 215-220.

1308. Ward, J.V., Zimmerman, H.J., and Cline, L.D., 1986, Lotic zoobenthos of the Colorado system, in Davies, B.R., and Walker, K.F., eds., The ecology of river systems: Dordrecht, The Netherlands, Dr W. Junk Publishers, p. 403-422.

1309. Ward, T.J., and Eckhardt, J., 1981, Analysis of potential sediment transport impacts below the Windy Gap Reservoir, Colorado River, in Adams, V.D., and Lamarra, V.A., eds., Aquatic resources management of the Colorado River ecosystem, proceedings of the 1981 symposium, Las Vegas, Nevada, November 16-18, 1981: Ann Arbor, Mich., Ann Arbor Science Publishers, p. 91-104.

1310. Waring, G.A., 1965, Thermal springs of the United States and other countries of the world-A summary, revised by R.R. Blankenship and Ray Bentall: U.S. Geological Survey Professional Paper 492, 383 p.

1311. Warner, J.W., Heimes, F.J., and Middleburg, R.F., 1985, Ground-water contribution to the salinity of the Upper Colorado River Basin: U.S. Geological Survey Water-Resources Investigations Report 84-4198, 113 p. 
1312. Washburne, H.D., 1872, Data on hot springs, in Statistics of mines and mining in the States and territories west of the Rocky Mountains, for the year 1870: U.S. Government Printing Office, p. 213-216.

1313. Washichek, J.N., Moreland, R.E., and Teilborg, J.R., 1972, Summary of snow measurements for Colorado and New Mexico, 1936-1972: U.S. Department of Agriculture, Soil Conservation Service, $208 \mathrm{p}$.

1314. Washichek, J.N., Shafer, B.A., and Teilborg, J.R., 1978, Summary of snow survey measurements for Colorado and New Mexico, 1971-1977: U.S. Department of Agriculture, Soil Conservation Service, $128 \mathrm{p}$.

1315. Water Education Foundation, 1990, Colorado River water map: Sacramento, Calif., Water Education Foundation, 1 sheet, scale 1:3,168,000, text included.

1316. Weatherford, G.D., 1974, Basin-wide planning and the problem of multiple jurisdictions, in Crawford, A.B., and Peterson, D.F., eds., Environmental management in the Colorado River Basin: Logan, Utah, Utah State University Press, p. 1-16.

1317. Weatherford, G.D., and Brown, F.L., eds., 1986, New courses for the Colorado River--Major issues for the next century: Albuquerque, N. Mex., University of New Mexico Press, 253 p.

1318. Weatherford, G.D., Nichols, Phillip, and Mann, D.E., 1974, Legal-political history of water resource development in the Upper Colorado River Basin; part I, summary of the legislative history of the Colorado River Storage Project; part II, the politics of water resource development in the Upper Colorado River Basin: National Science Foundation Report NSF/RA/E-74-384, 62 p. [Available from National Technical Information Service, Springfield, VA 22161 as NTIS Report PB-261 674/6.]

This study is in two parts. Part I chronicles the dominant events of the legislative history of the Colorado River Storage Project Act of 1956. The major political and legal decisions emanating from the Colorado River Compact of 1922 and resulting in the 1956 Act are identified. Part II approaches these historical events analytically from the perspective of political science. The persistence of distributive politics, in the face of increasing pressure of a more 'regulator' mode of decision making, is discussed in the context of some current problems such as water quality in the river. Also, several unresolved issues of public policy concerning Colorado River management are proposed.

1319. Weaver, G.D., 1974, Possible impacts of oil shale development on land resources: Journal of Soil and Water Conservation, v. 29, no. 2, p. 73-76.

1320. Weaver, G.D., 1983, Effects of wilderness legislation on water project development in Colorado: Fort Collins, Colo., Colorado Water Resources Research Institute Completion Report CR 124, $156 \mathrm{p}$.

Environmental policies embodied in the Wilderness Act, Wild and Scenic Rivers Act, and Endangered Species Act impose certain restrictions on the development of Colorado's water resources. Planning costs must be invested in complying with procedural requirements of the laws. Capital or operating costs may be increased

176 BIbliography, Indices, and Data Sources of Water-Related Studies, Upper Colorado River Basin, Colorado and Utah, 1872-1995 
because of construction delays, required engineering design changes, or spatial relocation of project facilities. In some cases, development opportunities will be completely foregone. The most pervasive conflicts identified in this study involve the endangered whooping crane and Colorado River fishes. New streamflow depletions in the Platte River system will adversely affect the whooping crane habitat in central Nebraska if such depletions occur between February 1-May 10 or September 16-November 15. Accordingly, new development will be given nonjeopardy biological opinions only if they can meet the required flow regime, either by providing storage releases or replacement water, or if they can offset the effects of small depletions by funding habitat improvement programs. Approval of projects affecting the Colorado River fishes have already been made contingent upon project operators adopting or funding various conservation measures, including the bypassing of minimum flows during critical months of the year.

1321. Weaver, R., 1968, Meteorology of major storms in western Colorado and eastem Utah: Washington, D.C., National Oceanographic and Atmospheric Administration Tech. Memo. HYDRO-7, 75 p.

1322. Weber, D.T., 1959, Effects of reduced stream flows on the trout fishery below Granby Dam, Colorado: Fort Collins, Colo., Colorado State University, Master's thesis, 149 p.

1323. Weber, E.M., 1979, Water quality control in the Colorado River Basin [abs.]: Geological Society of America Abstracts with Programs, v. 11, no. 7, p. 536.

1324. Weeks, H.J., 1924, Oil and water possibilities of parts of Delta and Mesa Counties, Colorado: Denver, Colo., Colorado Geological Survey Bulletin 28, $46 \mathrm{p}$.

1325. Wegner, D.L., 1985, Dividing the water; basic precepts of Colorado River water law, in Riparian ecosystems and their management, reconciling conflicting issues, Tucson, Arizona, 1985, Proceedings: Tucson, Ariz., p. 453-455.

The extent of riparian vegetation development along the rivers and streams which comprise the Colorado River System is a function of a myriad of legal and operational factors. The utilization of Colorado River water can be identified with several key issues, federal acts, and treaties. This paper will outline the major arguments and perceptions which devine the present day levels of water and hence the extent of riparian vegetation along the river corridors of the Colorado River system.

1326. Wegner, D.L., 1989, Colorado River law--Its development and impact on the operations of Glen Canyon Dam (final report): Bureau of Reclamation Report GCES-33/87, 21 p. [Available from National Technical Information Service, Springfield, VA 22161 as NTIS Report PB-89 143 523/XAB.1

The report describes the legal framework for the development of the Colorado River Basin, and the subsequent relationship to the operation of Glen Canyon Dam. Early development, history of the Colorado River Basin from 1870 to present, laws, compacts, and negotiations which define the allocation of Colorado River water between the seven Colorado River Basin states are presented. Future constraints to the management of available Colorado River water are discussed. 
1327. Weigel, J.F., 1987, Selected hydrologic and physical properties of Mesozoic formations in the Upper Colorado River Basin in Arizona, Colorado, Utah, and Wyoming--Excluding the San Juan Basin: U.S. Geological Survey Water Resources Investigations Report 86-4170, 68 p.

1328. Weigel, J.F., 1987, Selected water-level data for Mesozoic formations in the Upper Colorado River Basin, Arizona, Colorado, Utah, and Wyoming--Excluding the San Juan Basin: U.S. Geological Survey Open-File Report 87-397, 73 p.

1329. Weigel, J.F., 1988, Sources of hydrologic data on Mesozoic formations in the Upper Colorado River Basin and comparison of data analysis methods, in McLean, J.S., and Johnson, A.I., eds., Regional aquifer systems of the United States--Aquifers of the western mountain area, American Water Resources Association 23rd annual conference and symposium, Salt Lake City, Utah, November 1-6, 1987: Bethesda, Md., American Water Resources Association Monograph Series 14, p. 71-80.

1330. Weiner and Associates, 1976, Draft environmental impact statement, Aspen Metro Sanitation District, Snowmass Water and Sanitation District--201 wastewater facilities plans: Denver, Colo., U.S. Environmental Protection Agency, 119 p. [Available from National Technical Information Service, Springfield, VA 22161 as NTIS Report PB-257 589.]

The proposed action will provide for regional wastewater treatment in the combined Aspen and Snowmass resort study areas in Colorado. The study areas' principal river drainage is the Roaring Fork River which is in good condition but is threatened by increased future discharges from point and nonpoint sources. Additionally, present point sources do not have the facilities to meet effluent standards for ammonia, residual chlorine and suspended solids. Specified alternatives have only been proposed for domestic sewage treatment. Nonpoint source control remains an unresolved issue of this draft EIS. Existing facilities are recommended for expanded secondary treatment. Tertiary alternatives are also reviewed. Summertime land treatment was also proposed for both study areas. The proposed facilities will protect the Roaring Fork and Brush Creek. In the Snowmass area, this will be achieved by alleviation of pollution from point source discharges; in the Aspen area the older of the two existing plants will be closed, conforming to citizen preference and costbenefit analysis. The other plant will be correspondingly upgraded and since the net increase in capacity will be minimal, it is not expected that this expansion will be a growth stimulant. The Snowmass facility will also be expanded and this too is not expected to be an inducement for ill-advised growth. Unsolved issues for which remedial measures will be developed prior to the issuance of the final EIS include: development of structural and non-structural policy plans for the control of nonpoint sources; negotiation with land owners for summertime land treatment on designated sites; and an acceptable treatment approach for residual chlorine.

1331. Weisbecker, L.W., 1972, Technology assessment of winter orographic snowpack augmentation in the Upper Colorado River Basin--The impacts of snow enhancement, volume I, summary report: Menlo Park, Calif., Stanford Research Institute NSF-RA/E-72-010, 50 p. [Available from National Technical Information Service, Springfield, VA 22161 as NTIS Report PB-222 873/2.]

The report covers an assessment of the economic, legal, social, and ecological impact of a proposed project to increase the flow of the Colorado River by increasing the spring runoff of winter snowpack on the mountain tops of the Upper Colorado River

178 Bibliography, Indices, and Data Sources of Water-Related Studies, Upper Colorado River Basin, Colorado and Utah, 1872-1995 
Basin by cloud seeding of winter orographic storms. A summary is given of the specific findings of the study and the conclusions and recommendations.

1332. Weisbecker, L.W., 1972, Technology assessment of winter orographic snowpack augmentation in the Upper Colorado River Basin--The impacts of snow enhancement, volume II, technical report: Menlo Park, Calif., Stanford Research Institute NSF-RA/E-72-011, 629 p. [Available from National Technical Information Service, Springfield, VA 22161 as NTIS Report PB-222 $874 / 0$.

The report covers an assessment of the economic, legal, social, and ecological impact of a proposed project to increase the flow of the Colorado River by increasing the spring runoff of winter snow pack on the mountain tops of the Upper Colorado River Basin by cloud seeding of winter orographic storms. This volume presents the detailed information and data base used in arriving at the conclusions and recommendations provided in volume I (PB-222 873).

1333. Weisbecker, L.W., 1974, Snowpack, cloud-seeding, and the Colorado River--A technology assessment of weather modification: Norman, Okla., University of Oklahoma Press, 86 p.

1334. Welder, F.A., 1971, Ground-water reconnaissance of selected sites in Rocky Mountain National Park and Shadow Mountain National Recreation Area, Colorado: U.S. Geological Survey Open-File Report 71-320, 16 p.

1335. Welder, F.A., 1987, Unconsolidated deposits of the Piceance Basin, in Taylor, O.J., comp., Oil shale, water resources, and valuable minerals of the Piceance Basin-The challenge and choices of development: U.S. Geological Survey Professional Paper 1310, p. 57-62.

1336. Welles, B.C., 1981, Headwaters view of cloudseeding in the Colorado River Basin, in Adams, V.D., and Lamarra, V.A., eds., Aquatic resources management of the Colorado River ecosystem, proceedings of the 1981 symposium, Las Vegas, Nevada, November 16-18, 1981: Ann Arbor, Mich., Ann Arbor Science Publishers, p. 195-209.

1337. Wendel, H., and Dudek, D., 1989, Design and legality of an innovative approach to nonpoint source control, in Davis, F.E., Contributed papers and abstracts for the conference on water, laws, and management, Tampa, Florida, September, 17-22, 1989: Bethesda, Md., American Water Resources Association Special Publication 89-4, p. 8A-23--28.

1338. Wengert, N., [n.d.], Oil shale country fact book--Garfield, Mesa, Moffat and Rio Blanco Counties, Colorado: Atlantic Richfield Company.

1339. Wentz, D.A., 1974, Effect of mine drainage on the quality of streams in Colorado, 1971-72: Denver, Colo., Colorado Water Resources Circular 21, 117 p.

1340. Wesche, T.A., 1980, The WRRI Trout Cover Rating Method--Development and application (completion report): Bureau of Reclamation Report OWRT-B-032-WYO, 53 p. [Available from National Technical Information Service, Springfield, VA 22161 as NTIS Report PB-81 198 368.]

Trout cover can generally be described as object-oriented, having a water depth of at least 0.5 feet, a point water velocity of less than 0.5 feet per second, and a mean water velocity of less than 1.0 feet per second, and a mean water velocity of less than 
0.5 per second. Brown trout were found to be more cover-oriented than are brook or Colorado River cutthroat trout. A significant positive relationship was found to exist between the amount of cover available and the standing crops of brown trout.

1341. Westesen, G.L., 1975, Salinity control for western Colorado: Fort Collins, Colo., Colorado State University, Ph.D. dissertation, 251 p.

1342. Wetherbee, G.A., and Van Liew, W.P., 1988, Geophysically determined porosity of Paleozoic rocks in the Upper Colorado River Basin, in McLean, J.S., and Johnson, A.I., eds., Regional aquifer systems of the United States--Aquifers of the western mountain area, American Water Resources Association 23rd annual conference and symposium, Salt Lake City, Utah, November 1-6, 1987: Bethesda, Md., American Water Resources Association Monograph Series 14, p. 161-169.

1343. Wetherbee, G.A., and Van Liew, W.P., 1991, Geophysically estimated porosity of selected Paleozoic rocks in the Upper Colorado River Basin, Colorado, Utah, Wyoming, and Arizona: U.S. Geological Survey Water Resources Investigations Report 90-4049, $30 \mathrm{p}$.

1344. White, D.E., and Williams, D.L., eds., 1975, Assessment of geothermal resources of the United States--1975: U.S. Geological Survey Circular 726, 155 p.

1345. Whittig, L.D., Deyo, A.E., and Tanji, K.K., 1982, Evaporite mineral species in Mancos Shale and salt efflorescence, Upper Colorado River Basin: Soil Science Society of America Journal, v. 46, no. 3, p. 645-651.

1346. Whittig, L.D., Deyo, A.E., Tanii, K.K., and Higgins, C.G., 1986, Delineation and correlation of salinity to landforms and geologic formations, Upper Colorado River Basin: Davis, Calif., University of California Land, Air, and Water Resources Papers 100012, 143 p. [Available from National Technical Information Service, Springfield, VA 22161 as NTIS Report PB-87 176 244/XAB.]

The investigation was aimed at assessment of the potential contribution of dissolved mineral salts by natural lands in the Grand and Gunnison River valleys in the Upper Colorado River Basin. The Mancos, Sego, and Mount Garfield formations are important contributors of soluble salts. Springs and seeps within the study area are highly localized but result in significant differences in water quality and discharge between nearly identical adjoining watersheds. The majority of salts leave some local watersheds by groundwater flow through buried stream channels. The close correspondence between salinity and landforms provided the basis for construction of landform-salinity maps covering approximately $1070 \mathrm{~km} 2$ within the Grand Valley and Gunnison River Valley.

1347. Whittig, L.D., Tanji, K.K., Biggar, J.W., Evangelou, V.P., and Deyo, A.E., 1983, Salinity investigation in the West Salt Creek watershed, Colorado: Bureau of Reclamation Report OWRT-B-201-CAL(2), 177 p. [Available from National Technical Information Service, Springfield, VA 22161 as NTIS Report PB-83 203 406.]

This investigation was aimed at assessment of the potential for contribution of dissolved mineral salts to the Colorado River by natural forces acting within a small, representative watershed in the Upper Colorado River Basin. The $440 \mathrm{sq} \mathrm{km}$ West Salt 
Creek watershed in west central Colorado was chosen for the study. Certain geologic strata and geomorphic landforms were identified as major contributors of dissolved mineral salts, whereas others within the watershed contribute little to the salt load of streams of the area. The Late Cretaceous marine Mancos Shale, in particular, is a principal contributor of soluble salts.

1348. Wick, E.J., Hawkins, J.A., and Carlson, C.A., 1986, Colorado squawfish population and habitat monitoring, 1985: Fort Collins, Colo., Colorado Division of Wildlife and Colorado State University, Final Report SE-3-8, 80 p. [Also available is Final Report SE-3-7 for 1983-1984, published in 1985.]

1349. Wick, E.J., Lytle, T.A., and Haynes, C.M., 1981, Colorado squawfish and humpback chub population and habitat monitoring, 1979-1980: Denver, Colo., Colorado Division of Wildlife, Federal Aid to Endangered Wildlife, Job Progress Report SE-3-3, 156 p.

1350. Wick, E.J., Synder, D.E., Langlois, D., and Lytle, T.A., 1979, Colorado squawfish and humpback chub population and habitat monitoring: Denver, Colo., Colorado Division of Wildlife, Federal Aid to Endangered Wildlife, Job Progress Report SE-3-2.

1351. Willardson, L.S., Hanks, R.J., and Jurinak, J.J., 1979, Impacts of water and soils having sourcesink potentials on water and salinity management under irrigation in the Upper Colorado River Basin: Logan, Utah, Utah Water Research Laboratory.

1352. Williams, H.J., 1951, The operation of Taylor Reservoir and its effect on Gunnison River fishing: Denver, Colo., Colorado Department of Game and Fish, 28 p.

1353. Williams, J.S., 1975, The natural salinity of the Colorado River: Logan, Utah, Utah State University Water Research Laboratory Occasional Paper 7, $18 \mathrm{p}$.

1354. Williams, K.T., and Byers, H.G., 1935, Occurrence of selenium in the Colorado River and some of its tributaries: Industrial and Engineering Chemistry (Analytical Edition), v. 7, no. 6, p. $431-432$.

1355. Williams, M., 1980, Energy development scenarios for the Four Corners States and the Upper Colorado River Basin, a discussion, in Spofford, W.O., Jr., Parker, A.L., and Kneese, A.V., eds., Energy development in the Southwest, problems of water, fish and wildlife in the Upper Colorado River Basin, volume 1: Washington, D.C., Resources for the Future, Research Paper R-18, p. 153-178.

1356. Williams, R.E., 1982, Statistical identification of hydraulic connections between the surface of a mountain and internal mineralized sources: Ground Water, v. 20, no. 4, p. 466-478.

1357. Wiltzius, W.J., 1964-1967, Pre-impoundment investigations of the Curecanti Unit, Upper Colorado River Storage Project--Determination of the chemical and physical characteristics of the upper Gunnison drainage, job completion reports: Montrose, Colo., Colorado Division of Wildlife. 
1358. Wiltzius, W.J., 1971 and 1974, Post-impoundment investigations, Curecanti Unit, Upper Colorado River Storage Project--Determination of chemical and physical characteristics of the upper Gunnison drainage, job completion reports: Montrose, Colo., Colorado Division of Wildlife.

1359. Wiltzius, W.J., 1976, Some historic influences of reservoirs and irrigation diversions on flows, temperatures, and fish distribution in the Gunnison River: Fort Collins, Colo., Colorado Division of Wildlife, $100 \mathrm{p}$.

1360. Wiltzius, W.J., 1978, Some factors historically affecting the distribution and abundance of fishes in the Gunnison River, final report to Bureau of Reclamation, Upper Colorado region, Salt Lake City, Utah: Fort Collins, Colo., Colorado Division of Wildlife, 194 p. plus appendices.

1361. Windell, J.T., Willard, B.E., Cooper, D.J., Foster, S.Q., Knud-Hansen, C.F., Rink, L.P., and Kiladis, G.N., 1986, An ecological characterization of Rocky Mountain montane and subalpine wetlands: U.S. Fish and Wildlife Service Biological Report 86(11), 298 p.

1362. Wood, B.D., 1916, Stream-gaging stations and publications relating to water resources, 1885-1913; part IX, Colorado River Basin: U.S. Geological Survey Water-Supply Paper 340, p. 105-116.

1363. Woodling, J., 1985, Colorado's little fish--A guide to minnows and lesser known fishes in the State of Colorado: Denver, Colo., Colorado Division of Wildlife, $77 \mathrm{p}$.

1364. Woodling, J., 1993, Annual report on the biological assessment of the Eagle River Superfund Site, Eagle County, Colorado: Colorado Division of Wildlife, $21 \mathrm{p}$.

1365. Woodling, J.D., 1975, The Upper Gunnison River drainage: Denver, Colo., Colorado Department of Health, $70 \mathrm{p}$.

1366. Woodling, J.D., 1976, Pollution of the Slate River via a mine discharge and sewage treatment plant effluents: Denver, Colo., Colorado Department of Health, 20 p.

1367. Woodling, J.D., 1976, Water quality investigations, North Fork of the Gunnison River, Delta and Gunnison Counties, Colorado: Denver, Colo., Colorado Department of Health, 11 p.

1368. Woodling, J.D., 1977, Chemical and physical aspects of the Roan Creek ecosystem, 1975-1976: Denver, Colo., Colorado Department of Health, $54 \mathrm{p}$.

1369. Workman, J.P., and Keith, J.E., 1974, Economic aspects of erosion control practices in the Upper Colorado River Basin: Proceedings Utah Academy of Sciences, Arts, and Letters, v. 51, no. 1, p. 102-108.

1370. Wright Water Engineers, Inc., 1981, Evaluation of the potential for a groundwater supply for the town of Crested Butte, Gunnison County, Colorado: Denver, Colo., Wright Water Engineers, Inc., $16 \mathrm{p}$. 
1371. Wright, C.T., 1958, Water quality in the Upper Colorado River Basin and its relation to Reclamation projects: Salt Lake City, Utah, U.S. Public Health Service, 72 p. [Available from National Technical Information Service, Springfield, VA 22161 as NTIS Report PB-228 939/5.]

The study was made primarily for the purpose of assisting the Bureau of Reclamation in solving water quality problems being encountered in connection with the planning and operation of Reclamation projects. These problems include (1) the application of water quality requirements, (2) the effects of Reclamation projects on subsequent water use, and (3) the evaluation of chemical water quality data from sampling stations in the Upper Colorado River Basin.

1372. Wright, W.G., and Butler, D.L., 1993, Distribution and mobilization of dissolved selenium in ground water of the irrigated Grand and Uncompahgre Valleys, western Colorado, in Management of irrigation and drainage systems [meeting, American Society of Civil Engineers, Irrigation and Drainage Division, Park City, Utah, July 21-23, 1993]: New York, N.Y., American Society of Civil Engineers, p. 770-777.

1373. Wuerthele, M., 1976, Water quality survey of the Eagle River Basin, 1975: Denver, Colo., Colorado Department of Health, $101 \mathrm{p}$.

1374. Wydoski, R.S., 1980, Potential impacts of alterations in streamflow and water quality on fish and macroinvertebrates in the Upper Colorado River Basin, in Spofford, W.O., Jr., Parker, A.L., and Kneese, A.V., eds., Energy development in the Southwest, problems of water, fish and wildlife in the Upper Colorado River Basin, volume 2: Washington, D.C., Resources for the Future, Research Paper R-18, p. 77-147.

1375. Wydoski, R.S., Gilbert, K., Seethaler, K., McAda, C.W., and Wydoski, J.A., 1980, Annotated bibliography for aquatic resource management of the Upper Colorado River ecosystem:

U.S. Fish and Wildlife Service Resource Publication 135, 186 p.

1376. Wymore, I.F., 1974, Water requirements for stabilization of spent shale: Fort Collins, Colo., Colorado State University, Ph.D. dissertation, 137 p.

1377. Young, R.A., Franklin, W.T., and Nobe, K.C., 1973, Assessing economic effects of salinity on irrigated agriculture in the Colorado River Basin--Agronomic and economic considerations (final report): Fort Collins, Colo., Colorado State University NRE-15, 226 p. [Available from National Technical Information Service, Springfield, VA 22161 as NTIS Report PB-226 025/5.]

The purpose of this study was to derive the most appropriate procedure for evaluating the economic effects of salinity on users of irrigation water from the Colorado River. Literature and existing data relating to measuring adverse effects of salinity of irrigation water were reviewed. Scientific, technical, and professional literature bearing on the economic impact of salinity on irrigation uses also were studied. Results are given of a survey of the public economics of water pollution control. Soils and agronomic considerations, including predicting soil salinity levels, predicting crop yields in relation to soil salinity, and estimating effects of alternative on-farm management practices on crop response to salinity are discussed. The direct economic damages caused by increased salinity in irrigation water are assessed. Issues relating to assessment of indirect economic effects are provided. Findings and recommendations are given. 
1378. Young, R.A., Franklin, W.T., and Nobe, K.C., 1974, Evaluating agricultural effects of salinity abatement projects in the Colorado River Basin--Agronomic and economic considerations, in Flack, J.E., and Howe, C.W., eds., Salinity in water resources, Proceedings of the 15th annual Western Resources Conference, July, 1973, University of Colorado: Boulder, Colo., Merriman, p. 86-107.

1379. Young, R.A., and Leathers, K.L., 1981, Economic impacts of regional saline irrigation return flow management programs, in Yaron, D., ed., Salinity in irrigation and water resources:

New York, N.Y., M. Dekker, p. 201-214.

Examines the economic impacts of alternative on-farm water management policies for controlling saline irrigation return flows in part of the Upper Colorado River Basin, the Grand Valley of west-central Colorado. The annual salt contribution from the region's 56,000 irrigated acres is estimated to average over eight tons per irrigated acre. This high level results from seepage of irrigation water into extremely saline aquifers. Various policies for controlling saline return flows range from lining water conveyance channels through improving on-farm irrigation efficiency to the complete abandonment of some irrigated lands. The analysis is based on linear programming models of representative farm size categories. The models are derived from data collected in a detailed field interview survey of commercial farmers. Functions reflecting the direct costs of various non-structural control alternatives for the Grand Valley result. Also, indirect impacts on related economic sectors are traced. It is concluded that the adjustment of on-farm irrigation management practices are a relatively inexpensive method of dealing with the problem, and possible downstream benefits are probably not large enough to warrant more extensive measures.

I lowever, Lower Basin water users should bear a part of the cost of water quality improvement.

1380. Young, R.A., Radosevich, G.E., Gray, S.L., and Leathers, K.L., 1975, Economic and institutional analysis of Colorado water quality management: Fort Collins, Colo., Colorado Water Resources Research Institute Completion Report CR 61.

1381. Zacharakis, T.G., ed., 1981, Geothermal resource assessment of Waunita Hot Springs, Colorado: Colorado Geological Survey Special Publication 16,69 p.

1382. Zacharakis, T.G., Ringrose, C.D., and Pearl, R.H., 1981, Geothermal resource assessment of Ouray, Colorado: Denver, Colo., Colorado Geological Survey Resource Series 15, 70 p.

1383. Zimmerman, A.L., 1972, Air temperature observations and forecasts--Their relationship to the prediction of spring snowmelt in the Eagle River basin, Colorado, in Proceedings of the 40th annual meeting of the Western Snow Conference, Phoenix, Arizona, April 18-20, 1972: Fort Collins, Colo., Colorado State University, p. 30-36.

1384. Zimmerman, D., 1977, Solving Colorado's water problems: Fort Collins, Colo., Colorado Water Resources Research Institute PB-279 172, 36 p.

Several projects conducted by the Colorado Water Resources Research Institute are outlined. The report includes descriptive photographs and simplified procedural explanations designed for use by the general public. Sections of the report include: (1) High country irrigation reservoirs - Colorado's untapped recreation resource,

184 Bibliography, Indices, and Data Sources of Water-Related Studies, Upper Colorado River Basin, Colorado and Utah, 1872-1995 
(2) Colorado's economy - the role of water, (3) Answering the flood control benefit question, (4) Solving high country water and sewer problems - a planner's handbook, (5) Improving irrigation, (6) Heavy metals in groundwater - a mineral belt problem,

(7) Urban runoff - a water pollution problem, (8) From cells to plants - a breakthrough in salt-tolerant varieties, (9) Stabilizing river channels, (10) Water conservation a handbook for utility managers, (11) Water reuse - potential in the South Platte River Basin, and (12) Trapping the sun - to solve mountain sewage problems.

1385. Zimmerman, H.J., and Ward, J.V., 1984, A survey of regulated streams in the Rocky Mountains of Colorado, in Lillehammer, A., and Salveit, S.J., eds., Regulated rivers: Oslo, Norway, University of Oslo, p. 251-262.

1386. Glover, K.C., Naftz, D.L., and Martin, L.J., in press, Geohydrology of Tertiary rocks in parts of the Upper Colorado River Basin in Colorado, Utah, and Wyoming, excluding the San Juan Basin: U.S. Geological Survey Professional Paper 1411-B, 248 p.

1387. Holm, J.D., and Jones, Scott, 1985, Passive mine drainage treatment--An effective lowcost alternative, in Graves, D.H., and DeVore, R.W., Proceedings, 1985 symposium on surface mining, hydrology, sedimentology, and reclamation, Lexington, Kentucky, December 9-13, 1985: Lexington, Ky., University of Kentucky, p. 115-120.

1388. Holm, J.D., Sullivan, Timothy, and Stenulson, B.K., 1979, The restoration of Peru Creek: Denver, Colo., Colorado Department of Public Health, 63 p.

1389. Hurlbut, S.C., 1990, Effects of heavy metals on benthic macroinvertebrate communities in two high elevation streams, Colorado Front Range: Golden, Colo., Colorado School of Mines, Master's thesis, $80 \mathrm{p}$.

1390. Naftz, D.L., in press, Basin geochemistry of aquifer systems in Tertiary rocks of the Upper Colorado River Basin in Wyoming, Colorado, and Utah: U.S. Geological Survey WaterResources Investigations Report 95-4065, 103 p.

1391. Pitlick, John, and Van Steeter, Mark, 1994, Changes in morphology and endangered fish habitat of the Colorado River: Fort Collins, Colo., Colorado Water Resources Research Institute Completion Report CR 188, 24 p.

1392. Plumlee, G.S., Streufert, R.K., Smith, S.M., Wallace, A.R., Toth, M.I., Nash, J.T., Robinson, R., Ficklin, W.H., and Lee, G.K., 1995, Map showing potential metal-mine drainage hazards in Colorado, based on mineral-deposit geology: U.S. Geological Survey Open-File Report 95-26, scale 1:750,000.

1393. Robson, S.G., and Banta, E.R., in press, Ground water atlas of the United States, segment 2, Arizona, Colorado, New Mexico, and Utah: U.S. Geological Survey Hydrologic Investigations Atlas HA-730-C.

1394. Schenderlein, William, Hatami, Bahman, and Kraus, Julie, 1993, Ground water quality monitoring program, Colorado Western Slope: Denver, Colo., Colorado Department of Natural Resources, 30 p. 
1395. Schenderlein, William, Schupbach, Stephani, and Hatami, Bahman, 1993, Available ground water quality data in the Colorado and Gunnison River drainages, Colorado Western Slope: Denver, Colo., Colorado Department of Natural Resources, 23 p.

1396. Weiss, Emanual, in press, Summaries of simulations of ground-water flow in the Upper Colorado River Basin in Arizona, Colorado, New Mexico, Utah, and Wyoming, excluding the San Juan Basin: U.S. Geological Survey Professional Paper 1411-F, 455 p.

1397. Weiss, Emanuel, in press, Summary of the regional geohydrology of the Upper Colorado River Basin in Arizona, Colorado, New Mexico, Utah, and Wyoming, excluding the San Juan Basin: U.S. Geological Survey Professional Paper 1411-A, 153 p. 


\section{COAUTHOR INDEX}

Abbey, D. 1006

Abt, S.R. 951

Ackerman, D.J. 108

Adams, D.B. $\quad 390,427,903$

Adams, V.D. $\quad 326,451,523,584,589,794,808,905,1065,1273,1309,1336$

Adamson, K.C. 455

Addiego, J.C. 282

Ahrens, W.A. 553

Aldridge, B.N. 1288

Alken, G.R. $\quad 787$

Allman, C.H. 987

Anderson, B.M. 327

Anderson, C.L. $\quad 70$

Anderson, R.M. $\quad 865,866,867,868$

Andrascik, R. 666

Anzia, T.L. 1027

Appel, C.L. 711

Argyle, D.W. 644

Armstrong, E.L. 830

Arnow, T. 949

Aronson, D.A. 929

Auger, Camilla 1249

Averett, R.C. $\quad 58$

Averett, W.R. 734

Ayars, J.E. 1044

Azimi, A. 317

Banta, E.R. 1393

Bargsten, G. 71

Barnes, Ivan 378,947

Baron, J. 887

Barrett, J.W.H. 1035 
Barrett, P.R. 744

Barton, H.N. 117

Bates, J.W. 768

Battaglin, W.A. $\quad 493,494,901$

Bauer, D.P. 13

Beauvillain, Edouard 611

Becker, Edith 325

Bedunah, D. 204

Beeson, K.C. 20

Beetem, W.A. 682

Behnke, Robert $\quad 615,616$

Bencala, K.E. $\quad 542,784,785,786,787,789,790$

Bennett, G.L. 394

Bennett, J.D. $\quad 1250,1252,1253,1255$

Bennett, R.S. $\quad 1044,1047$

Benson, D.E. $\quad 54,55$

Bentall, Ray 1310

Bentley, R.G. 578

Berry, C.A. 311

Berry, C.R. 1124

Bertle, F.A. 436

Bessler, M.B. 99,1062

Beus, S.S. 485

Biggar, J.W. 1347

Binder, C.W. 376

Birch, Francis 295

Bishop, A.B. 845

Bishop, M.B. 1001

Bishop, W.E. 220

Bissell, S. 1111

Bissell, S.J. 168

Blake, G.M. 887

Blaney, H.F. 409 
Blankenship, R.R. 1310

Blattner, J.L. $\quad 324,1256$

Boerngen, J.G. 327

Boesch, B.E. 1081,1082

Boland 80

Bostrom, G.M. 1086

Botham, L.S. 560

Bourgeron, P. 640

Bowles, D.S. $\quad 745,746$

Boyd, E.L. 14,15

Bradley, W.C. $\quad 680,681$

Brandau, W.F. 398

Branson, M.D. $\quad 495,698$

Brecheisen, A.N. 635

Bredehoeft, J.D. 216

Brendecke, C. 706

Brennan, R. 13

Briggs, P.H. $\quad 117,941,942$

Brink, G.E. 695

Britton, L.J. $\quad 14,15,70$

Brogden, R.E. $\quad 457$

Brooks, Tom 6,196

Brown, D. 1003

Brown, F.B. $\quad 19,642$

Brown, F.L. $\quad 1006,1317$

Brown, H.E. 414

Brown, P.J. 415

Brown, T.C. $\quad 487$

Bruemmer, D.R. 808

Bryan, R.B. 676

Bryant, C.G. 708

Bucks, D.A. 455

Bulkley, R.V. 933 
Burdick, B.D. $\quad 27,1124$

Burdick, H.E. 170

Bureau of Reclamation 1186

Burgess, R.L. 1083

Burke, C. 893

Burt, R.J. $\quad 330,1277$

Burton, J.S. $\quad 496,1005,1078$

Butcher, K. 1002

Butler, D.L. $\quad 26,1372$

Byers, H.G. 1354

Byrd, W.J. 639

Cain, Doug $\quad 509,510$

Callender, J.F. $\quad 484,719,915$

Campbell, J.C. 1307

Campbell, W.J. $\quad 612,613$

Campbell-Osmundson, B. 650

Cannon, J.R. 19

Caputo, Richard 766

Carlson, C. 674

Carlson, C.A. $\quad 813,1124,1271,1348$

Carr, J.C. 510

Carr, J.E. 712

Chafin, D.T. $\quad 708,1097$

Champion, D.F. $\quad 320,655,656,657,658,661,662,663$

Chang, A.T.C. $\quad 185,612,613$

Chart, T.E. 768

Chase, E.B. $\quad 223,489,510,712,805,929,956$

Cheney, R.W. 282

Cheng, C.Y. 953

Chilingarian, G.V. 517

Choquette, A.F. $\quad 637,707$

Chronic, J. 840

Claassen, H.C. 1283 
Clapp, F.G. $\quad 425$

Clark, R.C. 952

Clemmer, G.H. 1271

Cline, L.D. $\quad 314,1308$

Coale, B.V. 810

Cochran, B.J. $\quad 1250,1251,1252,1253$

Coe, B.A. $\quad 916,917$

Coffin, D.L. 890

Colburn, G.W. 777

Collins, D.B. 968

Collins, D.L. $\quad 427,428,903,1288$

Colorado Mining Industrial Development Board 1216

Colorado Water Conservation Board 854

Colt, J. $\quad 872,875,876$

Columbia, R.K. 969

Connor, J.J. 327

Cooper, D.J. 1361

Cope, J.A. 1286

Cordes, E.H. 1285

Cordy, G.E. $\quad 420$

Corey, P. 316

Court, Arnold 349

Cowan, M. 424

Cox, S.K. 667

Craig, G. 1111

Craig, J.F. 314

Cranney, J.S. 768

Crawford, A.B. $\quad 32,89,172,284,415,432,529,764,926,997,1101,1108,1118,1316$

Crock, J.G. 1077

Crook, J.S. 449

Crow, L.W. 100, 1007

Crumpacker, D.W. 706

Cuevas, D.L. $\quad 655,656$ 
Curtis, B. 681

Curtis, H.A. 449

d'Arge, R.C. 19

Daniel, S.R. 735

Danielson, T.W. 390

Davidson, P. 1277

Davies, B.R. $\quad 1067,1068,1308$

Davies, P.H. $\quad 462,463,464,466,467,881$

Davis, F.E. 1337

Dawdy, D.R. 673

Deacon, J.E. 1121

Dean, W.E. 327

Deason, W.O. 893

DeBraal, J.P. 568

DeFeyter, K.L. 344

Deimel, M.A. 311

DeVore, R.W. 1387

DeVoto, R.F. 840

Deyo, A.E. $\quad 1345,1346,1347$

Dickerman, A.R. 64

Dinicola, R.S. 638

Dodge, D.P. 186

Doesken, N.J. 223

Doherty, T.J. 408

Dorn, W.S. 716

Dortignac, E.J. 1116

Dow, R.L. 639

Downing, D. 352

Doyle, W.W. 956

Dudek, D. 1337

Duffy, C.J. $\quad 31$

Duncan, A.C. 1254

Dunford, E.G. $\quad 110$ 
Dutton, X.W. 218

Ebling, J.L. 345,1254

Eckhardt, J. 1309

Ecology Consultants, Inc. 49

Eggleston, K.O. 64

El-Ashry, M.T. 553

Elliott, J.G. 902

Ellis, H.H. 568

Elmblad, W.R. $\quad 768$

Elsberry, R.L. 975

Emerson, R.L. 567

Enck, E.D. 1021

Epis, R.C. $\quad 484,719,915$

Erdman, J.A. 327

Evangelou, V.P. 1347

Evans, N.A. 712

Evans, R.G. $\quad 71,1045,1046,1294,1295,1296,1297$

Evans, W.C. 947

Falkenborg, D.H. 206

Fall, T.C. 577

Fargo, R.L. 967

Fassett, J.E. 680

Feder, G.L. $\quad 327,787,788,790,791$

Felmlee, J.K. 181

Ferchau, H.A. 973

Ficklin, W.H. $\quad 940,941,942,1392$

Fisher, S. 578

Fisk, D.W. $\quad 309,426,999,1086$

Fitzhugh, T.L. 566

Fitzpatrick, L.A. $\quad 740$

Flack, J.E. $\quad 556,742,1378$

Flinckinger, S.A. 871

Flynn, T. 804 
Fontane, D.G. $\quad 424$

Forst, B.A. 974

Foster, R.G. 220

Foster, S.Q. 1361

Fox, R.L. 333

Frandsen, E.R. $\quad 64$

Franklin, D.P. 844

Franklin, W.T. $\quad 1377,1378$

Frederick, R.H. 809

Freethey, G.W. 1094

French, O.F. 455

French, R.D. 291

French, R.H. $\quad 315,513,520,572,606,632,738,836,996$

Fullerton, H.H. 32

Galyean, K.C. 7

Gardner, R.L. 1075

Garland, T.R. $\quad 978$

Garnsey, M.E. 100

Gary, J.H. 292, 1072

Gaufin, A.R. 48

Gearhart, M.J. $\quad 509,510$

Gellis, A. 1012

Gery, B.H. 1002

Gibbons, D.C. 553

Gifford, R.O. 515

Gilbert, K. 1375

Giles, T.F. 103

Glanzman, R.K. $\quad 217,218$

Gleick, P.H. 847,848

Gloersen, Per $185,612,613$

Glover, K.C. 1094

Goad, Julie 61

Goddard, K.E. 7 
Goldman, C.R. $\quad 1080$

Golus, H.M. 408

Goodchild, M.S. 494

Goodell, B.C. 436

Goolsby, D.A. $\quad 70$

Gorshkov, S.P. $\quad 645,646$

Gough, L.P. 327

Graul, W. 1111

Graul, W.D. $\quad 168$

Graves, D.H. 1387

Gray, S.L. 1380

Gregg, R. 394

Grenney, W.J. 279, 745, 746

Griest, J. 394

Grim, P.J. 65

Grozier, R.U. 95, 96

Hahn, D.A. 180

Hailu, T. 368

Haise, H.R. $\quad$ 659, 660

Hale, A. 872

Hall, L. 1277

Halls, J. 1277

Hanks, R.J. 1351

Hannaford, J.F. $\quad 348,349$

Hanson, R.L. 762

Harbeck, G.E., Jr. 1102

Harding, B.L. 112

Hardy, T.B. 1272

Harlin, J.M. 47

Harnish, R.A. 789

Hasfurther, V.R. $\quad 22,346,772,1028$

Hatami, Bahman $\quad 1394,1395$

Hatchett, J.L. 647 
Hawkins, D.B. 1099

Hawkins, J.A. 1348

Hawkins, R.H. 943

Hay, L. 902

Hay, L.E. $\quad 47,698,772$

Hayden, F.V. 429

Hayes, B.R. 446

Haynes, C.M. $\quad 1124,1349$

Healy, F.C. 968

Hearne, G.A. 565

Heermann, D.F. 1025

Heiken, G. 648

Heimes, F.J. 1311

Hembree, C.H. $\quad 573,574$

Hendricks, D.M. 326

Hereford, Richard $\quad 445,446$

Herring, J.R. 327

Herrmann, R. $347,495,664,698$

Hess, C.T. $\quad 887$

Hickman, D. 291

Higgins, C.G. 1346

Hill, J.J. 804

Hillen, H.H. 365

Hiner, M.M. $\quad$ 1250, 1251, 1252

Hinkley, T.K. 327

Hoban, E. 872

Hodges, H.E. 208

Holden, Paul 615,616

Holden, P.B. 1272

Holsinger, J.R. 1305

Hood, J.W. 421, 422, 1095, 1096

Horak, G. 872, 875

Horak, M.L. 876 
Hornsby, A.G. 686

Hotchkiss, R.H. 279

Hovey, G.L. 35

Howard, C.S. 224

Howe, C.W. $\quad 396,556,742,814,1248,1249,1378$

Howitt, R.E. 699

Humphries, William 454

Hunt, J.D. 997

Huszar, P.C. 1036

Hynes, J.L. $\quad 570$

Ikelman, J.A. 65

Ingvalson, R.D. 203

Israelsen, E.K. $\quad 543,569$

Jacoboni, J.M. 29

Jacoby, G.C., Jr. 1079

Jakasch, J. 352

Jarrett, R.D. $\quad 208,209,280,345,773$

Jarvis, C.S. 533

Jaynes, R.A. $\quad 454$

Jenkins, R.A. $\quad 428,1252$

Jenkins, S.H. $\quad 205,746$

Jensen, D.T. 1020

Jeton, A.E. 29

Johnson, A.I. $\quad 418,419,440,441,1329,1342$

Johnson, B.L. 425

Johnson, E.B. 201

Johnson, R.M. 455

Johnston, C.E. 22

Jones, K.C. 1020

Jones, Scott 1387

Jordan, W.R. 1087

Josberger, E.G. 185

Julian, P.R. $\quad 100$ 
Jurinak, J.J. $\quad 316,317,1351$

Kaeding, L.R. $\quad$ 27, 769, 770, 897, 898

Keith, F. 843

Keith, J.E. 1369

Keith, J.R. 327

Kelmelis, J.A. $\quad 493,612,901$

Kemp, H.T. 1083

Kemper, J.B. 314

Kendall, P.A. 408

Kent, H.C. $\quad 914,917$

Kerbs, Lynda 741

Keys, J.W. 1082

Kharaka, Y.K. 941

Kiladis, G.N. 1361

Kilburn, P.D. 288

Kimball, B.A. $\quad 421,422,708$

Kimzey, J.R. 1027

Kincaid, D.C. $\quad 195,320,658$

King, D.L. $\quad 572$

King, R.U. 1284

Kirby, W.H. $\quad 356,672,900$

Kircher, J.E. $\quad 707,974$

Kleinman, A.P. 19

Klemetson, S.L. $\quad 74$

Klusman, R.W. $\quad 327,791$

Knapp, Loey 496

Kneese, A.V. $\quad 33,51,76,190,341,721,820,1006,1060,1061,1355,1374$

Knipe, O.D. 731

Knud-Hansen, C.F. 1361

Kondratieff, B.C. 1306

Korom, S. 316

Kraus, Julie 1394

Kreider, J.F. $\quad 554,1248,1249$ 
Kretschman, R.G. $\quad 324,1250,1253,1254,1255,1256,1257$

Kroeker, B.E. 1292

Kroner, R.C. 624

Krueger, R.P. 179,180

Kruger, P. 710

Kruse, E.G. $\quad 195,320,1081,1082$

Kuhn, Gerhard $\quad 196,902$

Kundu, S.S. 661

Kunkel, Fred 605

Kunkel, J.R. 1072

Kysar, L.N. 976

Lakin, H.W. 20, 1099

Lamarra, V.A. $\quad 8,326,451,523,584,589,794,808,905,1065,1273,1309,1336$

Lambou, V.W. 635

Lane, T.J. 36

Lane, W.L. 424

Lanfear, K.J. $\quad 47$

Langford, R.H. 890

Langlois, D. 1111,1350

Laronne, J.B. 1021

Leaf, C. 353

Leaf, C.F. 1086

Leathers, K.L. $\quad 1379,1380$

Leavesley, G.H. 47, 494, 495

Lederer, N. 641

Lee, G.K. 1392

Lee, L.C. $\quad 277,311$

Leopold, L.B. 1080

Lester, O.C. 449

Lewis, M. $\quad 872,875$

Lewis, W.M., Jr. 826

Li, R.M. 1027

Liebermann, T.D. $\quad 835,882$ 
Lillehammer, A. 1066, 1385

Lindberg, R. 1003

Lindner-Lunsford, Jaye 509,510

Ling, C.H. 613

Link, D. 881

Litke, D.W. 330

Livingston, R.K. 208

Loeb, S.L. 1080

Lof, G.O. 1301

Lohman, L.C. $\quad 814,815,816$

Long, S.G. 426

Longmire, P.A. 968

Love, L.D. 436

Love, S.K. 551

Ludington, S.D. 832

Lusby, G.C. 1013

Lyon, S.A. 815

Lytle, T.A. $169,170,500,1124,1349,1350$

Madole, R.F. 840

Maest, A.S. 941

Magoon, O.T. 763

Maletic, J.T. 68

Mancuso, B.F. 71

Mangan, P. 1270

Mann, D.C. 978

Mann, D.E. 1318

Margheim, G.A. 1301

Marino, M.A. 699

Marston, R.A. $\quad 22,346,772,1028$

Martin, L.J. 1386

Mathieu, G. 585

Maura, W.S. 885

McAda, C.W. $\quad 27,1375$ 
McArthur, E.D. 204

McCain, J.R. 588

McCall, S.K. 179

McCall-Ellington \& Morrill, Inc. $\quad 780$

McCalpin, J. 316

McCarthy, K.P. 918

McHugh, J.B. 942

McKee, M. 74, 75

McKee, M.L. 569

McKee, T.B. $\quad 63,307$

McKnight, D.M. $\quad 58,59,60,61,542$

McLean, J.S. $\quad 418,419,440,441,1329,1342$

McNeal, J.M. 327

McWhorter, D.B. $\quad 458,955,1035,1037$

Meev, H.E. 817

Messer, J.J. 451

Meyer, E.L. $\quad 474$

Middelburg, R.M. 638

Middleburg, R.F. 1311

Miller, C. 516

Miller, C.L. 789

Miller, D.D. 869

Miller, G.C. 1050

Miller, W.H. $\quad 1124,1270,1271$

Milliken, J.G. $\quad 715,716$

Minckley, W.L. 1121

Minges, D.R. 209

Moody, C.D. 836

Moody, D.W. $\quad 223,510,712,805,929$

Moore, C.V. 200

Morel-Seytoux, H.J. $\quad 323,842$

Moreland, J.A. 368

Moreland, R.E. 1313 
Morrison, M.L. 887

Motooka, J.M. 391

Mott, D.E. 1073

Moulder, F.A. 474

Mueller, D.K. $\quad 707,821,980$

Munroe, R.J. 295

Murphy, A.H. 555

Murphy, D.M. 346

Murray, D.K. 199

Mustard, E.W. 963

Muth, R.T. $\quad 186,500,501,502,503$

Mutz, K.M. 311

Naftz, D.L. 1386

Nakayama, F.S. 455

Narayanan, R. 75

Nash, J.T. 1392

National Park Service 18

Neely, B.E. 640

Nelson, J.D. 951

Nesler, T.P. $\quad 492,768$

Neuhold, J. 32

Neuman, S.P. 318

Nichols, Phillip 750, 1318

Nickerson, R. 666

Nicol, K.J. 798

Nilson, B. 1270

Nobe, K.C. $\quad 1377,1378$

Noonan, W.R. 740

Norton, V.C. 398

Nussbaum, M.T. 75

Oakland, G.L. $\quad 573,574$

Oaks, S.D. 799

Ogg, J.E. $\quad 972$ 
Olinger, C. 5

Olsen, S.R. 195,320

Olson, D.C. 572

Olson, J.B. 518

Oriel, S.S. $\quad 981$

Orlovsky, S. 561

Orr, D.V. $\quad 556,557$

Orsborn, J.F. 987

Osen, L.L. 837

Osmundson, B.C. $179,180,650$

Osmundson, D.B. $\quad 619,620$

Oster, J.D. 203

Owen, J.B. 90

Ozima, M. 680,681

Padungchai, Sumol 845

Pajewski, R. 627

Parker, A.L. $\quad 33,51,76,190,341,721,820,1006,1060,1061,1355,1374$

Parker, R.S. $\quad 29,47,347,494,664$

Parker, S. 452

Parkhurst, Z. 872

Parks, B.O. 494

Parrish, L.P. 881

Patt, R.O. 7

Paulson, R.W. $\quad 223,510,712,805$

Payton, E.A. $\quad 112,487$

Pearl, R.H. $\quad 40,41,42,43,1382$

Pearson, E.A. 544

Pearson, J.G. 220

Pendergast, D.M. 644

Penley, R.D. 741

Pennington, A.J. 43

Penton, M.A. 921

Perry, H.A. 292 
Peters, N.E. 1073

Peterson, D.F. $\quad 32,89,172,284,285,415,432,529,764,997,1101,1108,1118,1316$

Phoenix, D.A. 574

Plantz, G.G. 201

Poole, J.L. 647

Poppoff, I.G. 1080

Porcella, D.B. 76

Porter, K.W. $\quad 914,917$

Ports, M.A. 1014

Post, F.J. $\quad 451,801$

Presser, T.S. 378

Prestel, M. 761

Prewitt, C.G. 674

Price, D. 64

Prichett, H.R. 1082

Pupacko, Alex 29

Queen, R.W. 759

Radosevich, G.E. $\quad 1036,1038,1380$

Rahel, F.J. 88

Rango, A. 613

Ranville, J.F. $\quad 735,736$

Rapp, J.R. 489

Rector, C.D. 841

Redmond, K.T. 29

Reed, H.S. 795

Reid, M. 640

Reid, V.H. $\quad 731,732$

Reinecke, S.E. 1302

Relf, M.M. 969

Remington, J.D. 69

Remmers, M.A. 974

Repplier, F.N. 918

Rhoades, J.D. 203 
Richards, D.B. 566

Richter, D.B. $\quad 307,637$

Riehl, Herbert $\quad 753,754$

Riggins, R.E. 938

Riley, J.P. 206, 279, 543, 569

Rinaldi, S. 1298

Ringrose, C.D. $\quad 327,791,919,1382$

Rink, L.P. 1361

Ritschard, R. 452

Roberts, R.S. $\quad 223$

Robinson, C.S. 566

Robinson, R. 1392

Robson, S.G. $\quad 509,510$

Rodriguez, G.J. 881

Roemer, T.A. 117

Roll, Lynne 816

Roluti, M.J. 450

Rondeau, R. 641

Rosholt, J.N. 181

Ross, L.W. 953

Rouse, J.V. 78

Ruddy, B.C. 29, 1059

Runnells, D.D. 618

Russell, J.D. 1278

Rutherford, W.H. 69

Saheli, F. $\quad 825$

Salas, J.C. 1300

Salveit, S. 1066

Salveit, S.J. 1385

Sangani, S. 317,318

Sass, J.H. 295

Sathaye, J. 452

Saunders, J.F. 706 
Schall, J.D. 1027

Schillinger, G.R. $\quad 78$

Schleusener, R.A. 100

Schneck, D.J. 804

Schneider, P.A., Jr. $\quad 509,510$

Schumm, S.A. $\quad 445,446,447,498,601,677,678$

Schupbach, Stephani 1395

Schurmeier, D.R. 558

Schuster, R.J. $\quad 424$

Seaman, W.R. 379

Seethaler, K. 1375

Severson, R.C. $\quad 327,1077$

Shacklette, H.T. $\quad 327$

Shafer, B.A. 1314

Shafer, W.H., Jr. 78

Shaffer, R.W. $\quad 348,349$

Shaw, W.D. 558

Sheikh-ol-Eslami, Bahman 560

Shen, H.W. $\quad 679,936,1287$

Shepherd, T.A. 951

Sherer, C.R. 364

Sherk, G.W., Jr. 815

Shiosaki, K. 978

Sieh, D. 1005

Simpson, E.S. 318

Simpson, H.J. 585

Singh, V.P. 679

Sinley, J.R. $\quad 465,466,467$

Sinning, James $\quad 615,616$

Skaggs, R.L. 329

Skinner, M.M. 321

Skogerboe, G.V. $37,71,373,374,375,376,377,402,403,404,405,792,880,955,1293,1294,1295$, 1296,1297 
Skogerboe, R.K. 792

Smerdon, E.T. 1087

Smillie, G.M. 666

Smith, C.L. 391

Smith, F.F. 20

Smith, H.L., Jr. 972

Smith, J.L. 29

Smith, K.S. $\quad 735,736,940,941,942$

Smith, N.F. 170

Smith, R. 1270

Smith, R.L. $\quad 789$

Smith, S.D. 171

Smith, S.M. 1392

Smith, S.W. $\quad 377,405,1046,1297$

Snow, K.M. $\quad 493,612,901$

Soil Conservation Service 164

Somers, W.P. 904

Sparling, E.W. 1075

Spofford, W.O., Jr. $\quad 33,51,76,190,341,721,820,1006,1060,1355,1374$

Stack, M.W. 408

Stalnaker, C.B. 532

Stamm, G.G. 831

Stanford, J. 22

Stanford, J.A. 1307

Stanton, W.P. 223

Stearns, H.T. 1070

Steinheimer, J.T. 1256,1257

Stenulson, B.K. 1388

Stevens, D.R. 993

Stewart, C.E. $\quad 431,432$

Steyaert, L.P. 494

Streufert, R.K. 1392

Su, S.T. $\quad 936,1287$ 
Subitzky, Seymour $\quad 61,378$

Sullivan, Timothy 1388

Sun, P. 822

Sun, R.J. 1094

Sundaram, A.V. 322

Sunday, G. 1021

Surdick, R.F. 48

Sutley, S.J. 363

Swanson, G.A. 841

Swendsen, G.L. 525

Swenson, R.S. 1082

Swope, H.M. 69

Sylvester, M.A. 357

Synder, D. 674

Synder, D.E. 1350

Synder, J.H. $\quad 200,822$

Tanji, K.K. $\quad 367,1021,1345,1346,1347$

Targy, M.M. 474

Taylor, J.H. $\quad$ 1044, 1047

Taylor, O.J. $\quad 739,1092,1335$

Teilborg, J.R. 1313, 1314

Teller, R.W. $\quad 509,510$

Thacker, E. $\quad 20$

Theobald, P.K. 363

Thomas, J.L. 1030

Thompson, A.L. 179

Thompson, Andrew 650

Thompson, J.R. $\quad 111,414,732$

Thompson, K.G. 870

Thorn, K.A. $\quad 787$

Thorson, J.E. 812

Tidball, R.R. $\quad 327$

Tobin, R.L. $\quad 281,509,510$ 
Todd, J. 965

Torgersen, T. 585

Torpy, M.F. $\quad 74$

Torres, J. 674

Toth, M.I. 1392

Town, W.W. 899

Tracey, R.J. 809

Treat, B.J. 1035

Trock, W.L. 1036

Troendle, C.A. 1080

Trumbly, A.S. 816

Tuccy, K.E. 716

Tucker, J.M. 203

Tucker, K.S. 346

Turner, G.T. 732

Turner, R.L. $\quad 46$

Tyus, H.M. $\quad 813,1124,1271$

U.S. Department of Agriculture 257, 258

U.S. Salinity Laboratory 11

Udis, Bernard 554

Ugland, R.C. $\quad 324$

Ullery, S.J. $\quad 588$

Updergraff, D.M. 953

Valdez, R.A. 1124

Valentine, V.E. 530

Van Gerpen, E.D. 924

Van Haveren, B.P. 70

Van Liew, W.P. $\quad 1342,1343$

Van Steeter, Mark 1391

Van Voast, W.A. 368

Van Zyl, D. 951

Vaux, H.J., Jr. 1075

Veenhuis, J.E. 13, 209 
Vincent, R.E. 634

Vitter, M.W. 965

Vlachos, E.C. 1036

Voegeli, P.T., Sr. 1017

Vorster, P. 1275

Vudhivanich, V. 424

Waddell, K.M. 950

Wagaman, D. 872

Walker, K.F. $\quad 1067,1068,1308$

Walker, W.R. $\quad 37,71,373,374,375,376,377,402,403,404,405,955,1039,1040,1041,1042,1043$, 1044, 1045, 1046, 1047

Wallace, A.R. 1392

Walling, D.E. 1073

Walters, W.H. 329

Wambolt, C.L. 204

Ward, J.C. 517

Ward, J.R. 354

Ward, J.V. $\quad 314,1065,1066,1067,1068,1385$

Ward, R.C. $\quad 878,880$

Wardell, R.E. 951

Waring, G.A. 1070

Waterstone, M. 330, 1277

Watson, C.C. 1012

Watts, K.R. $\quad 509,510$

Weatherford, G.D. $\quad 586,587,750,812$

Weaver, R.M. 1073

Wegner, D.L. 808

Weiyan, Tan $356,672,900$

Welder, F.A. $\quad 217,218,567,739,1098$

Wen, F. 936,1287

Wentz, D.A. 102,823

Wershaw, R.L. 790

West, D.C. 1083 
West, R.E. 843

West, S.W. 1285

White, L.D. 947

Whittig, L.D. 367

Wick, E. 674

Wick, E.J. $\quad 500,1273$

Wilberg, D.E. $\quad 421,422$

Wildung, R.E. $\quad 434,435,978$

Willard, B.E. 1361

Williams, D.L. 1344

Williams, J.S. 805

Williams, O.O. 1023

Williams, R.D. 952

Williams, R.S., Jr. 1000

Williamson, C.E. 408

Wilson, E.A. $\quad 1250,1251,1252,1253,1255,1257$

Wilson, W.W. 567

Windell, J.T. 963

Windham, M.P. 745

Winter, T.C. 670

Wohl, E.E. 799

Woodling, J. 540

Worthington, E.B. 544

Wright, W.G. 180

Wuerthele, W. 881

Wycoff, L.C. 503

Wydoski, J.A. 1375

Yair, A. 676

Yaron, D. $\quad 559,1379$

Yen, T.F. 517

Yeo, J.B. 449

Yeodjevish, V.M. 100

Yeoman, R.A. 832 
Yoder, R.E. $\quad 655,656,657$

Young, D.A. $\quad 655,656,658,661,662,663$

Young, J.T. 559

Young, R.A. $\quad 85,433,697,1075$

Zachara, J.M. $\quad 434,435$

Zacharakis, T.G. $\quad 187,918,919$

Zellweger, G.W. $\quad 59,60,61,62,787,790$

Zimmerman, E.A. $\quad$ 1095, 1096

Zimmerman, H.J. $\quad 314,1308$ 


\section{SUBJECT INDEX}

AB Lateral hydropower project, Gunnison River 1076

Abies lasiocarpa, evapotranspiration $\quad 454$

Acid-mine drainage (see also mine drainage)

Cadmium 299, 735, 736

Copper 298, 299, 735, 736

Deer Creek 788

Dissolved organic carbon 735

Heavy metal capture 298, 299

Lead 298

Metal-mine drainage

Hazards map 1392

Water quality 823

Metals precipitation 953

Sediment adsorption 735

Snake River 788

Stream reclamation 965

Streambed sorption 736

Water quality 823,1339

Zinc 298, 735, 736

Acid precipitation 305

Adobe Creek, dissolved solids 882

Agriculture 1101, 1264

Acreage reduction

Salinity 557

Water supply 557

Land use, Grand Valley 1293

Programming models, National Water Assessment Model 798

Salinity $\quad 432$

Agronomics 1377

Economics 1377

Salinity control $\quad 253,431$

Agronomics 1378

Economics 1378

Salt load 315

Grand Valley $\quad 376,520,1290,1291$

Selenium 20,408

Water quality 822

Water supply 822

Agronomics

Salinity 1377

Salinity control 1378

Algae

Green Mountain Reservoir 333

Stream regulation 314

Alkali Creek

Sedimentology 380

Water quality 182,1373

Alkylpyridines 978

Alluvium

Parachute Creek 1335

Piceance Basin 1335 
Salt content $\quad 675,677,678$

Salt storage 498

Alpine zone, climate change 959

Alum Creek, water quality 1367

Aluminum

Deer Creek 1099

Precipitation 1099

Snake River 786, 1099

Chemistry 786

Alva B. Adams Tunnel, Colorado-Big Thompson Project, engineering geology 512

Ammonia

Criteria 881

Fruita 560

Grand Junction 560

Amphipods (Amphipoda), Rocky Mountains

Distribution 1305

Habitat 1305

Anthracite Creek, water quality 1367

Anvil Points Oil Shale Facility, water pollution 978

Aquatic biology, Parachute Creek, environmental impact analysis 398

Aquatic biota 410

Gunnison River Basin 179

Irrigation drainage 179,180

Metals 459, 460, 464, 465, 466, 1389

Oil shale 1001

Production 924

Ridgway Reservoir, inorganics 896

Stream regulation 1303

Sweitzer Lake 179

Uncompahgre River, inorganics 896

Uncompahgre River Basin 179

Aquatic ecosystems

Coal mining $\quad 451,801$

Energy development 451,801

Oil shale development 801

Aquatic habitat, vertebrate associations 168

Aquatic insects, trace elements 219, 220, 221

Aquatic invertebrates 861

Habitat alteration 921

Aquatic management, Rocky Mountain National Park 993

Aquatic resources 584

Management $8,326,905$

Values 589

Bibliography 1375

Aquifer tests, Glenwood Springs 442

Aquifers

Alluvial 287, 1049

Cobble 157

Geochemistry 631,1390

Grand Junction 157

Hydrogeology 708

Maps 422, 708, 782

Piceance Basin 739

Regional Aquifer-Systems Analysis (RASA) $418,419,420,421,422,439,440,441,442$,

443, 1094, 1095, 1096, 1343, 1386, 1390, 1396, 1397 
West Sharrard Gulch, hydrogeology 1049

Area 58, Northern Great Plains and Rocky Mountain coal provinces, hydrology 196 Arid lands, irrigation and salinity, bibliography 191

Artesian water supply, Grand Junction 718

Artesian wells 66

Aspen

Flood studies 1127

Ground water 114

Hydrogeology, permeability 115

Silver mines, dewatering 726

Aspen (Populus tremuloides)

Evapotranspiration 454

Water use 111

Aspen Metro Sanitation District, wastewater treatment facility, environmental impact statement 1330

Aspinall Unit

Colorado River, effects on fishes 770

Gunnison River, effects on fishes 770

Atmospheric circulation, Gunnison River Basin 771

Atmospheric models

Climate change, East River Basin 698

Orographic Precipitation Model 495,698

Atmospheric water balance 957

Cloud seeding 958

Avalanche Springs 1070,1310

Bacteria 1182, 1183

Gunnison irrigation system 665

Thermal effluent, water quality 804

Trickle irrigation systems 455

Bacteriology, Gunnison River Basin 1026

Bacterioplankton, Dillon Reservoir 826

Badger Wash Basin

Grazing 1115

Biology 731, 732

Hydrology 731,732

Infiltration 1103

Runoff 730

Sediment yield 730

Infiltration capacity 1013

Runoff 727, 1013

Sediment yield 727

Soils 1115

Basin characteristics 974

Basin response, statistical tests 824

Battlement Mesa Project

Public health 1240

Water quality 1240

Beaver Creek, water quality 1373

Beavers (Castor canadensis), management 69

Best management practices, salinity control, Grand Valley $\quad 1294,1295,1296$

Bibliography

Aquatic resource management 1375

Arid lands irrigation, salinity 191

Colorado geology $16,17,36,596,597,639,840$ 
Desalination 1239

Endangered and threatened species, fishes

616

Energy development, water resources 86

Evaporation 1239

Fisheries 278

Fishes 616

Biology 894

Geothermal reports 918

Ground water $36,425,1280$

Hydrogeology 908

Irrigation effects on water quality 1223

Limnology 894

Maps 595

Mineral resources 1015

Natural resource information 614

North-central Colorado 597

Northwestern Colorado 596, 614

Oil shale 118,979

Environmental references 990

Phreatophytes 1239

Water quality, salinity 807

Western Colorado 36

Big Salt Wash, flood studies 1131

Bighorn Creek, water quality 1373

Biogeochemistry, Snake River 786

Biological assessment 1181

Eagle River Superfund Site $\quad 539,540,761,948,1364$

Biology, effects from grazing

Badger Wash Basin 731, 732

Grand Junction 728

Black Canyon of the Gunnison National Monument $\quad 57,481,482,485,486,545$

Fishes 633, 634

Geology 308, 484

$$
\text { Maps } 483
$$

History 308

Instream Flow Incremental Methology (IFIM) 869

Physical Habitat Simulation Model (PHABSIM) 869

Physiography 484

Sedimentology 197

Streamflow, fish studies 52,869

Trout, streamflow 869

Water and sewer system environmental assessment $\quad 271$

Black Gore Creek

Trace metals 1073

Water quality 1373

Black Mesa, hydrology 414

Blue Mesa Reservoir

Effects of reservoir operations, ecology 594

Eutrophication 1162, 1164

Fish studies 1360

Geomorphology 1109

Hydrologic models 1078

Land use planning 1109

Limnology $291,1162,1164$

216 Bibliography, Indices, and Data Sources of Water-Related Studies, Upper Colorado River Basin, Colorado and 
National Eutrophication Survey 1162,1164

Nutrients 1162, 1164

Recreation 1109

Tropic level classification 80

Water quality 102,522

Blue River

Water supply 82

Fish studies

Green Mountain Reservoir water releases 944

Salmonid 868

Trout 862

Geology 535

Molybdenum

Geochemistry 618

Transport 617

Nonpoint source water pollution 266

Streamflow, Froude number 1287

Water quality $101,333,1160$

Wetlands creation 426

Blue River Basin, water quality 1157

Management plan 886, 1163

Blue River-South Platte Project 126, 127

Geology 478

Bluestone Reservoir Project, water quality 1184

Boco Mountain, vegetation cover, hydrology 729

Bonytail chub (Gila elegans) 621

Dissolved solids 933

Life history 1271

Recovery plan 1190

Recovery prospects 1271

Salinity 933

Booth Creek, water quality 1373

Brook trout (Salvelinus fontinalis), habitat 1340

Brown trout (Salmo trutta)

Black Canyon of the Gunnison National Monument 869

Habitat 1340

Population dynamics, Taylor River 864

Brush Creek 1368

Water quality $101,231,1373$

Bugs (Hemiptera)

Distribution 306

Habitat separation 306

Bureau of Reclamation projects

Fishes 1019

Endangered and threatened species $\quad 55,630$

Water quality 1371

Wildlife 1019

Buttes Oil and Gas, water quality 23,973

Caddisflies (Trichoptera), Rocky Mountain regulated streams 1304

Cadmium

Acid-mine drainage

Heavy metal capture $\quad 298,299$

Ion exchange capture 298

Sediment adsorption $\quad 735$ 
Streambed sorption 736

In aquatic macroinvertebrates 219,220

Calcium 388

Metal-mine drainage 823

Canon Creek Springs 906

Canyon Creek

Runoff 406

Water quality 823

Carbon Creek, water quality 182

Carr Creek 1368

Carrying capacity 415

Castle Creek

Flood studies 1127

Runoff 406

Water quality 231

Castor canadensis, management 69

Catostomidae, Gunnison-Arkansas Project 194

Cattle Creek Basin

Water quality, ground water 103

Water supply, ground water 103

Cebolla Creek, water quality 24, 25

Cebolla Hot Springs 838, 1070, 1310

Water quality 391

Cement Creek, water quality 1002,1365

Cement Creek Spring 1070, 1310

Chipeta Creek, water quality 1367

Chloride 388

Cholera, water quality 972

Cimarron River, water quality 410

Cimarron Spring 378

Hydrogeochemistry 947

Clean Lakes Project, Dillon Reservoir 706

Clear Creek 1368

Cliff Creek, water quality 1367

Climate change

Alpine zone 959

Atmospheric models 698

East River Basin 698

Hydrology 772

Gunnison Gorge, bed-material entrainment 347

Gunnison River Basin

Channel morphology 902

Geographic information systems 47,494

Hydrology 901, 902

Water resources $29,47,494$

Hydrologic models 847

East River Basin 698

Water allocation $\quad 487$

Streamflow 846, 847, 848

Colorado-Big Thompson Project 672

Water supply 846,848

Climate information, Colorado River management 555

Climatology 988, 1007

Data 


\section{Gunnison 1025}

Gunnison River Basin 29

Mountain Meadow Research Center 1025

Eagle River Basin, snowmelt 1383

Monthly summary 63

Patterns 514

Clinoptilolite, Acid-mine drainage, heavy metal capture 298, 299

Cloud seeding 131,1104,1333, 1336 (see also weather modification)

Assessment of snowpack augmentation 1331, 1332

Atmospheric water balance 958

Environmental assessment 488

Environmental impact statement 132

Grand Mesa 1104

Coal

Streamflow 348

Ground water 524,604

Hydrology

Area 58, Northern Great Plains and Rocky Mountain coal provinces 196 Interior Province, western region 70

Transport, saline water 766

Coal Creek, water quality $101,182,233,823,1002,1367$

Coal lease tracts, hydrology and subsidence potential 106

Coal mining

Aquatic ecosystems $\quad 451,801$

Economics 1249

Gunnison River 1249

Hydrologic effects 107

Hydrologic system management 543

Rapid Creek Basin 107

Water quality $451,801,1114,1249$

Water resources 14,15

Cochetopa Creek, water quality 289

Colony Shale Oil Project 499

Environmental study 1107

Hydrogeology 292

Colorado, water in history and development 684

Colorado-Big Thompson Project 147, 153

Alva B. Adams Tunnel, engineering geology 512

Annual operating plans 162

Colorado River fisheries 1187

Cost-benefit analysis 552

Geology 511

Granby Pump Canal, ground water 12

Reservoirs and lakes

Limnology 874

Water pollution 1174

Streamflow, climate change 672

Water management 558

Windfall gains 21

Windy Gap Project

Environmental statement 145,161

Colorado National Monument, erosion 810

Colorado Plateau

Colorado River 


Age 722
Development 724
Drainage and faults 734
Ground water, trace elements 592
River system development 723
Wetlands 9

Colorado River $186,188,207,412,416,429,571,685,802,829,989,1022,1317$

"15-mile reach"

Colorado squawfish (Ptychocheilus lucius) $\quad 620,897,898$

Endangered and threatened species, fishes 897,898

Razorback sucker (Xyrauchen texanus) 897, 898

Streamflow recommendations 620,898

Age 92,720

Colorado Plateau 722

Development 680,783

Colorado Plateau 724

Drainage 645, 819

Effects of Aspinall Unit on fishes 770

Geologic history 94,563

Geology 977

Maps 1315

Natural resource 128

Origin $79,93,94,534,681$

Regional assessment study 1268

Colorado River Augmentation Demonstration Program 1104

Colorado River Basin 475, 760, 764, 1033, 1210

County area tabulations 1222

Development 926, 1031, 1032, 1108

Economic base survey 1230

Environmental protection 1108

Ground water quality data 1395

Land ownership 1226

Profile survey 519,1197

River mileage tabulations 1220

State area tabulations 1222

Colorado River Basin Pilot Project 131, 825

Evaluation report 349

Colorado River Basin Salinity Control Act $529,763,1133$

Colorado River Basin Salinity Control Program 1135

Colorado River Basin Salinity Control Project

Grand Valley Unit

Economics 144

Environmental impact statement $\quad 156,158$

Land resources 144

Salinity 144

Salt pickup 151

Water resources 159

Lower Gunnison Basin Unit 130

Colorado River Basin Water Quality Control Project $\quad 1175,1224,1232,1237,1238,1242$

Colorado River Compact $\quad 562,895,1318$

Colorado River cutthroat trout (Salmo clarki pleuriticus)

Habitat 1340

Requirements 88

Status 121 
Colorado River Salinity Control Program 938

Colorado River Simulation System (CRSS) 282, 450, 1014

Colorado River Storage Project 129, 163

Environmental impact statement

Crawford Dam and Reservoir 133, 134, 136

Curecanti Unit 133, 134, 136

Paonia Project, benefit/impact reappraisal 1134

Colorado River Storage Project Act, legislative history 1318

Colorado River Water Quality Improvement Program 607, 830

Environmental statement 141,164

Lower Gunnison Unit

Environmental impact statement 148

Environmental statement 155

Hydrogeology 143

Hydrosalinity 149

Winter water 160

Saline water use 146

Status report 150

Colorado squawfish (Ptychocheilus lucius)

Colorado River "15-mile reach" $\quad 620,897,898$

Decline 619

Stream regulation 1119

Dissolved solids 933

Ecology 1018, 1121

Habitat monitoring $674,1348,1349,1350$

Habitat requirements $501,502,531$

Streamflow 620

Heavy metal analysis 649

Larval distribution 500

Life history 1018

Life strategies 1120

Limiting factors 501,502

Management 1121

Metals 649,668

Monitoring program 768

Organochlorine contaminants 668

Petroleum hydrocarbons 668

Population 674, 1348, 1349, 1350

Recovery plan 1192

Salinity 933

Tolerance 871

Status 121

Streamflow 620,769

Colorado State University, salinity research, Grand Valley 252

Colorado Water Resources Research Institute 270, 1384

Compacts (see interstate compacts)

Conundrum Spring 1310

Cooper Creek, water quality 920

Copper

Acid-mine drainage

Heavy metal capture 299

Ion exchange capture 298

Sediment adsorption 735

Streambed sorption 736 
Metal-mine drainage 823

Mining 491

Corn irrigation, saline ground water 663

Cost-benefit analysis

Colorado-Big Thompson Project 552

Colorado River Storage Project, Paonia Project 1134

Salinity 559

Cottonwood (Populus) 1050

Cottonwood Creek, water quality 1367

Crawford Reservoir

Water quality 102

Water supply 109

Crested Butte

Ground water 456

Wetlands 276

Water supply 1370

Crested Butte Coal Field, water resources 14

Crops

Saline ground water 657,663

Irrigation requirements 662

Water use 655,656

Cross Creek

Yield, Grand Valley 1035

Water quality 101,1373

Wetlands 1085, 1086

Crystal Reservoir, fish studies 1360

Crystal River

Nonpoint source water pollution 266

Plan and profile survey, maps 725

Water-power resources 687

Water quality 101, 231, 233, 1002

Crystal River Basin, ground water

Water quality 103

Water supply 103

Crystal River Valley, geology 411

Crystal Dam and Reservoir, environmental impact statement $\quad$ 133, 134, 136

Curecanti National Recreation Area

Fishes, metals 666

Water quality $1,2,852,853$

Water supply 82

Curecanti Unit, Upper Colorado River Storage Project $\quad 1357,1358$

Effects on fishes 770

Environmental impact statement $133,134,136$

Limnology 644

Dallas Creek Water Project

Fish and wildlife analysis 237

Flood control 1125

Public health 1231

Water quality 1231

Water resources 1231

Dams, Gunnison River, physiochemistry 1065

Data centered architecture 1005

Data generalization, hydrologic response 479

Deadhorse Creek, streamflow, forest management practices 1112 
De Beque, sediment discharge 177

Debris flow, hydrologic implications 280

Deer Creek

Acid-mine drainage 788

Aluminum 1099

Dissolved organic carbon 789

Sorption 787

Humic substances 790

Iron 1099

Macroinvertebrates, benthic 1389

Manganese 1099

Metal precipitates 788,1099

Metals 1389

Microorganisms 789

Trace metals 790

Tracers 59,61

Deldorado Creek, water quality 24,25

Delta County

Coal lease tracts, hydrology and subsidence potential 106

Flood studies 1132

Gunnison Gorge Wilderness Study Area 117

Oil resources 1324

Road construction, environmental impact statement 1173

Springs, radioactive 181

Water quality 1367

Water resources 1324

Dendrochronology 1010,1079

Denudation 1008

Denver Water Department

Reservoir monitoring report 982

Thermal analysis report 984

Water quality monitoring report 983

Desalination 253, 1062, 1239, 1290, 1291

Bibliography 1239

Dillon Reservoir

Bacterioplankton 826

Clean Lakes Project 706

Eutrophication 705, 1165

Evaporation 390, 1059

Land use 705

Limnology 1160, 1165

Metals 757

Molybdenum 1160

Transport 617

National Eutrophication Survey 1165

Nutrients 826, 1160,1165

Storage capacity 13

Water diversion 13

Water pollution

Nonpoint source $\quad 266,1337$

Trading program 352,1337

Water quality 102,1160

Dissolved organic carbon

Acid-mine drainage 735 
Deer Creek 787, 789

Hydrologic controls 542

Snake River 542,787

Dissolved organic material, Snake River 786

Dissolved solids $2,78,636,673,707,835,882$

Bonytail chub (Gila elegans) 933

Colorado squawfish (Ptychocheilus lucius) 933

Discharge 837

Endangered and threatened species, fishes 933

Humpback chub (Gila cypha) 933

Maps 388

Ground water 389

District 10 , water quality management plan $235,302,303$

Dotsero Springs 1070, 1310

Energy development, water use 335

Hydrogeochemistry 336

Salinity 1266

Salinity control $130,738,1058$

Water quality 336

Doughty Springs 507

Droughts 223

Hydrology, Gunnison River Basin 900

Eagle, water quality 457

Eagle County

Eagle River Superfund Site $539,540,761,948,1172,1364$

Geology 411, 526, 977

Ruedi Dam and Reservoir 879

Springs, salinity control 1058

Water and sewer facilities plan 251

Water quality 101

Eagle River

Management plan 886

Dissolved solids 882

Fish studies 861

Trout 865,866

Nonpoint source water pollution 266

Runoff 406

Trace metals 1073

Waste load allocation 780

Water quality $101,410,438,1373$

Eagle River Basin

Air temperature, snowmelt 1383

Water quality 1373

Management plan 886

Eagle River Superfund Site

Biological assessment $\quad 539,540,761,948,1364$

Remedial action 1172

Superfund Record of Decision 1172

Eagle River Valley, water quality 457

East River

Macroinvertebrates, aquatic 888

Water quality $182,289,290,304,410,888,920,1002,1365$

East River Basin 
Climate change

Atmospheric models 698

Hydrologic models 698

Hydrology 772

Data generalization, hydrology 479

Ground water 456

Precipitation-Runoff Modeling System $\quad 664,698$

Water quality 1373

Monitoring program 1265

East River Valley, wastewater treatment facilities plan 184

Eby Creek, water quality 1373

Ecology 76, 341

Blue Mesa Reservoir, reservoir operations 594

Colorado squawfish (Ptychocheilus lucius) $\quad$ 1018, 1121

Plants, lakes 599

Riparian vegetation 204

Trout, Gunnison River 945

Wetlands

Montane and subalpine zone 1361

Rocky Mountains 1361

Economics 1246, 1247

Coal mining 1249

Colorado-Big Thompson Project, cost-benefit analysis 552

Colorado River Basin 1230

Colorado River Basin Salinity Control Project, Grand Valley Unit 144

Energy development, salinity 845

Erosion control 1369

Oil shale development 473

Oil shale leasing program, environmental protection 239

Salinity $559,642,716,1149$

Agriculture 1377

Salinity control $372,373,374,375,556,1150$

Agriculture 1378

Investment planning model 364

Irrigation return flow 697,1379

Salt gradient ponds 561

Streamflow value 112

Water allocation institutions 85

Water conservation 556

Water pollution 554

Water quality 1248

Management 1380

Water reuse 715,814

Water supply 1248

Ecosystem stability, Gunnison River 1063

Ecosystem study, Roan Creek 1368

Effluent

Bacteria 804

Uranium mills 1004

Water pollution, Slate River 1366

Eisenhower Memorial Tunnel, Straight Creek tunnel site, ground water 566

Endangered and threatened species, fishes $27,54,954,1320$

Aspinall Unit 770

Bibliography 616 


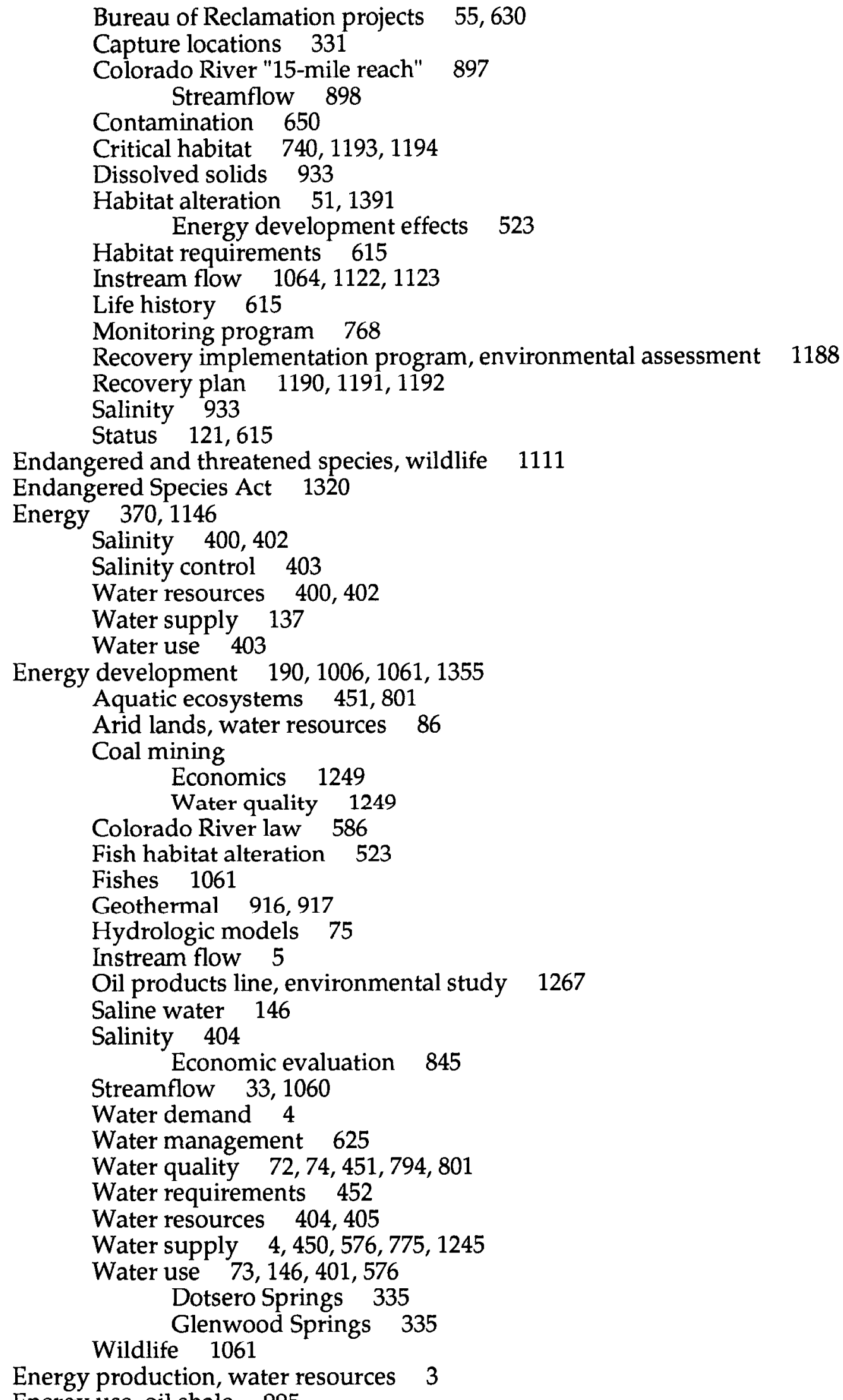


Engelmann spruce (Picea engelmanni), evapotranspiration 454

Engineering geology

Alva B. Adams Tunnel, Colorado-Big Thompson Project 512

Crystal River Valley 411

Roaring Fork River Valley 411

Environmental analysis, oil shale 517

Environmental assessment

Black Canyon of the Gunnison National Monument, water and sewer systems

Cloud seeding 488

Minerals, public lands 940

Recovery implementation program, endangered and threatened species, fishes

Weather modification 488

Environmental geology

Crystal River Valley 411

Roaring Fork River Valley 411

Williams Fork River Basin 350

Environmental impact analysis

Oil shale plants, Parachute Creek 225, 227

Parachute Creek, aquatic biology 398

Environmental impact statement (EIS)

Cloud seeding 132

Colorado River Basin Salinity Control Project, Grand Valley Unit $\quad 156,158$

Colorado River Storage Project 133, 134, 136

Colorado River Water Quality Improvement Program, Lower Gunnison Unit 148

Curecanti Unit, Crystal Dam and Reservoir 133, 134, 136

Mount Emmons mining project 1195

Oil shale development 119, 122

Road construction 1173

Uranium mill tailings site

Grand Junction 1136,1137

Rifle 1138

Wastewater treatment facilities

Aspen Metro Sanitation District 1330

Granby Sanitation District 360

Snowmass Water and Sanitation District 1330

Three Lakes Water and Sanitation District 1088

Upper Eagle Valley Sanitation District 1168, 1169

Vail Water Sanitation District 1168,1169

Weather modification 132

Environmental law 89

Environmental management 285

Environmental report, Rocky Point Pumped Storage Project 857

Environmental statement

Colorado-Big Thompson Project

Green Mountain Reservoir water marketing 161

Windy Gap Project 145

Colorado River Water Quality Improvement Program $\quad$ 141, 164

Lower Gunnison Unit 155

Gunnison River, wild and scenic river study $\quad 850,854$

Environmental study

Oil shale leasing program 1145

Oil products line 1267

Oil shale 990

Colony Shale Oil Project 1107 
Ephemeroptera, Gunnison River 1307

Erosion 471

Colorado National Monument 810

Control, economics 1369

Grasslands 1116

Salinity 1051

Eutrophication $\quad 705,1162,1164,1165,1166,1167$

Eutrophication survey

Blue Mesa Reservoir 1162, 1164

Dillon Reservoir 1165

Grand Lake 1166

Green Mountain Reservoir 1167

Shadow Mountain Lake 1166

Evaporation 803, 1239

Bibliography 1239

Dillon Reservoir 390, 1059

Williams Fork Reservoir 390, 1059

Evapotranspiration

Trees 454

Fall Creek, wetlands 1085, 1086

Feasibility study

Gunnison River Basin 504, 505, 506

Uncompahgre River Basin 504, 505, 506

Federal Water Pollution Control Act

Enforcement actions 1218

Regional impacts 849,1269

Salinity control 68

Fish distribution $236,532,702,1124$

Colorado squawfish (Ptychocheilus lucius), larval 500

Gunnison River 1359, 1360

Redside shiner (Richurdsoriius balteatus (richardson)) 503

Fish management

Grand Lake 381

Lake Granby 381, 393

Rocky Mountain National Park 993

Shadow Mountain Lake 381

Fish population 1083

Brown trout (Salmo trutta) 864

Colorado squawfish (Ptychocheilus lucius) 674, 1348, 1349, 1350

Humpback chub (Gila cypha) 674, 1349, 1350

Fish studies 1270

Black Canyon of the Gunnison National Monument, streamflow 869

Blue Mesa Reservoir 1360

Blue River $\quad 862,868$

Green Mountain Reservoir water releases 944

Brown trout (Salmo trutta)

Population dynamics 864

Recruitment and survival 869

Contamination 650

Crystal Reservoir 1360

Eagle River 861, 865, 866

Eagle River Superfund Site 539,540

Forest Lake 44

Fryingpan-Arkansas Project 394 
Fryingpan River $\quad 861,862,863,865,866,868,870$

Gunnison River $861,862,863,867,868$

Abundance 1360

Distribution 1359, 1360

Effects of Taylor Park Reservoir 1352

Streamflow 52,53, 869

Trout 945

Metals $459,460,464,465,466$

Morrow Point Reservoir 1360

Piceance Creek Basin 930

Rainbow trout (Salmo gairdneri), recruitment and survival 869

Reservoir water releases 944

Roaring Fork River $\quad 865,866$

Salmonid 870

Habitat 868

Taylor River $\quad 863,868$

Streamflow $167,859,860,861,863,864,865,866$

Tomichi Creek, channelization effects 166

Trout $862,863,864,865,866,869,870,945$

Fisheries

Bibliography 278

Biology 894

Colorado River, Colorado-Big Thompson Project 1187

Fishes 27, 54, 186, 236, 351, 610, 813, 954, 1067

Abundance 532, 1124

Aspinall Unit 770

Bibliography 616

Black Canyon of the Gunnison National Monument 633,634

Bureau of Reclamation projects $55,630,1019$

Capture locations 331

Colorado River "15-mile reach" $\quad 897,898$

Critical habitat 740

Curecanti National Recreation Area, metals 666

Dallas Creek Water Project 237

Dissolved solids 933

Energy development 1061

Grand Mesa Project 170

Grand Valley, organochlorine contaminants 669

Guidebook 50, 379, 1363

Gunnison-Arkansas Project 194

Habitat, sediment transport 936

Habitat alteration 51,820

Energy development 523

Habitat requirements 615

Introduced species 820

Life history 615

Metals concentration 666

Minnows, guidebook 1363

Monitoring program 768

Native, habitat 1273

Nonnative 492

Organochlorine contaminants 669

Rocky Point Pumped Storage Project 857

Salinity 933 
Status $121,615,1124$

Streamflow

Alteration $362,872,875,876,1322,1374$

Colorado River "15-mile reach" 898

Suckers (Catostomidae) 194

Survival and mortality 39

Sweitzer Lake 39

Water allocation 721

Water quality 1374

West Divide Project 169

Flood control, Dallas Creek Water Project, Uncompahgre River 1125

Flood studies $773,1126,1129,1260,1264$

Aspen 1127

Big Salt Wash 1131

Castle Creek 1127

Flood protection costs, Grand Junction uranium mill tailings site 328

Fruita 1131

Grand Junction $328,1126,1129$

Grand River (Colorado River) 839

Gunnison, flood insurance 183,383

Rates map 382

Gunnison County, map 1144

Gunnison River 359, 839, 1126, 1129, 1131, 1132

Hunter Creek 1127

Hydrology 590

Reservoir management 1275

Leach Creek 1129

Lewis Wash 1129

Little Salt Wash 1131

Palisade 1130

Parachute Creek 1055

Reed Wash 1131

Regulated streams 116

Roan Creek 1055

Roaring Fork River 1127

Tomichi Creek 359

Uncompahgre River 1132

Floods 223, 528, 793, 904

Fluoride 397

Fool Creek Experimental Watershed, forest management practices, water supply 692

Forest Lake, fish studies 44

Forest management practices

Deadhorse Creek, streamflow 1112

Fool Creek Experimental Watershed, water supply 692

Fraser Experimental Forest, sediment yield 689,690

Forest succession, water supply 454

Fraser Experimental Forest

Deadhorse Creek, streamflow 1112

Fool Creek Experimental Watershed, water supply 692

Sediment yield 692

Forest management practices $\quad 689,690$

Snowmelt 436, 691

Streamflow 436

Forest management practices 1112 
Streams, water chemistry 1080

Water supply 691,692

Fraser River

Nonpoint source water pollution 266

Streamflow 937

Water quality $10,101,756$

Fraser River Basin, water quality management plan 886

Froude number, Blue River 1287

Fruita

Ammonia 560

Flood studies 1131

Geology 1009

Fryingpan-Arkansas Project

Annual operating plans 162

Fish studies 394

Fryingpan River

Fish studies $861,868,870$

Trout $862,863,865,866$

Geology 526

Runoff 406

Water quality 101,231

Garfield County 1368

Geology 411

Grand Hogback Coal Field 15

Ground water, Leadville Limestone 1098

Oil shale 1338

Piceance Creek Basin, fish studies 930

Project Rulison $\quad 202,682,1282,1283,1285$

Rifle uranium mill tailings site 583,1138

Springs 567

Salinity control 1058

Water quality, Project Rulison 682

Wells 567

Geochemistry

Aquifers 631, 1390

Data 46

Hunter-Fryingpan Wilderness Area 832

Mancos Shale 366

Maps 45

Metals precipitation $953,994,1099$

Mine drainage 941,942

Metals precipitation 953,994

Molybdenum 618

Porphyry Mountain Wilderness Study Area 832

St. Louis Peak Roadless Area 45,46

Sediments 327

Soils 327

Vegetation 327

Williams Fork Further Planning Unit 46

Williams Fork Roadless Area 45

Geographic information systems (GIS) 1005

Glenwood Springs 799

Gunnison River Basin

Climate change 47,494 


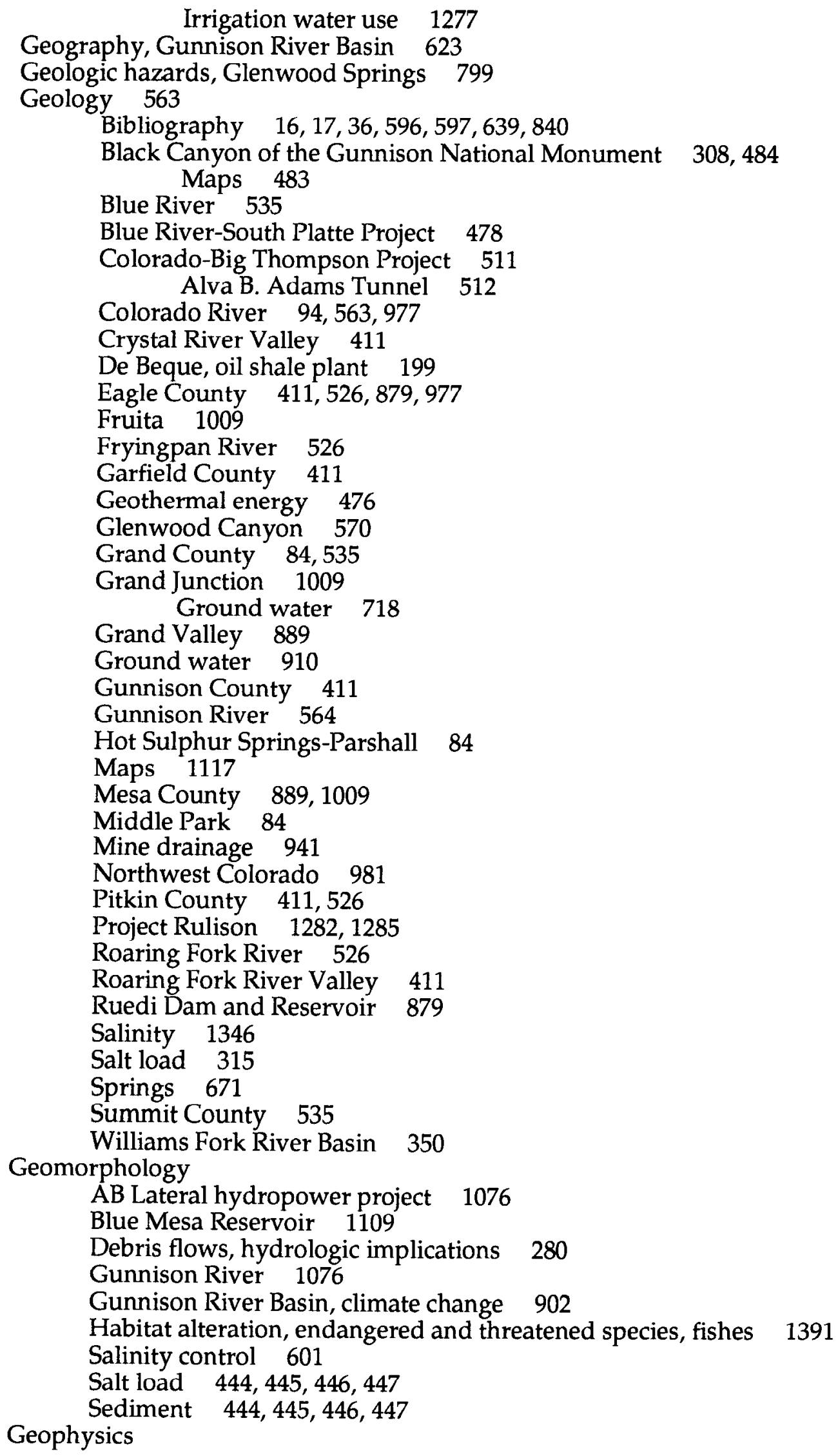


Geothermal energy 626

Ground water exploration, resistivity method 800

Porosity 1342, 1343

GEOTHERM 81

Geothermal energy $\quad 211,238,911,991$

Commercialization program 212, 213

Development $210,916,917$

Geology 476

Geophysics 626

Glenwood Springs 214

Industrial markets 215

Leases 98

Ouray 214

Geothermal gradients, maps 648,967

Geothermal reports, bibliography 918

Geothermal resources 909,913

Appraisal $40, \mathbf{4 1}$

Assessment $\quad 286,838,919,1344,1381,1382$

Guidebook 286

Cebolla Hot Springs 838

Hot Sulphur Springs 919

Maps 913

Ouray 1382

Rocky Mountains 293

Use feasibility 843

Waunita Hot Springs 838,1381

Geothermal water, Lake City 774

Gila cypha

Dissolved solids 933

Habitat monitoring $674,1349,1350$

Habitat requirements 501,502

Habitat suitability index curves 1272

Life history 1271

Limiting factors 501,502

Monitoring program 768

Population 674, 1349, 1350

Recovery plan 1191

Recovery prospects 1271

Salinity 933

Status 121

Gila elegans 621

Dissolved solids. 933

Life history - 1271

Recovery plan 1190

Recovery prospects 1271

Salinity 933

Glenwood Canyon, geology 570

Glenwood Springs (springs) 378, 1070, 1310

Aquifer tests 442

Energy development, water use 335

Hydrogeochemistry 336,947

Salinity 1266

Salinity control $130,738,1058$

Water quality 336 
Glenwood Springs (town)

Geographic information systems 799

Geologic hazards 799

Geothermal energy 214

Gore Creek

Risk assessment 799

Nonpoint source water pollution 266

Waste load allocation 780

Water quality $101,755,1373$

Granby Dam, streamflow, fishes 1322

Granby Pump Canal, ground water 12

Granby Sanitation District, wastewater treatment facility, environmental impact statement 360

Grand County

Geology 84,535

Water quality 101

Wetlands 1000

Management plan 886

Williams Fork Further Planning Area 46

Williams Fork Roadless Area 45,363

Grand Hogback Coal Field, water resources 15

Grand Junction

Aquifers 157

Ammonia 560

Flood studies 1126, 1129

Geology 718, 1009

Grazing

Biology 728

Hydrology 728

Uranium mill tailings site

Environmental impact statement 1136, 1137 、

Flood protection costs 328

Ground water 1139

Ground water contamination risk assessment $\quad 579$

Remedial action plan 1136, 1137, 1139

Soils 1141

Stream survey 1219

Water pollution 1219

Water sampling and analysis plan 581

Grand Lake

Water supply, ground water 718

Eutrophication 1166

Fish management 381

Limnology 1166

National Eutrophication Survey 1166

Nutrients 1166, 1170

Water quality $102,1147,1170$

Grand Mesa

Cloud seeding 1104

Limnology 922

Water supply 946

Grand Mesa Project

Fish and wildlife analysis $\quad 170$

Water quality 1153 


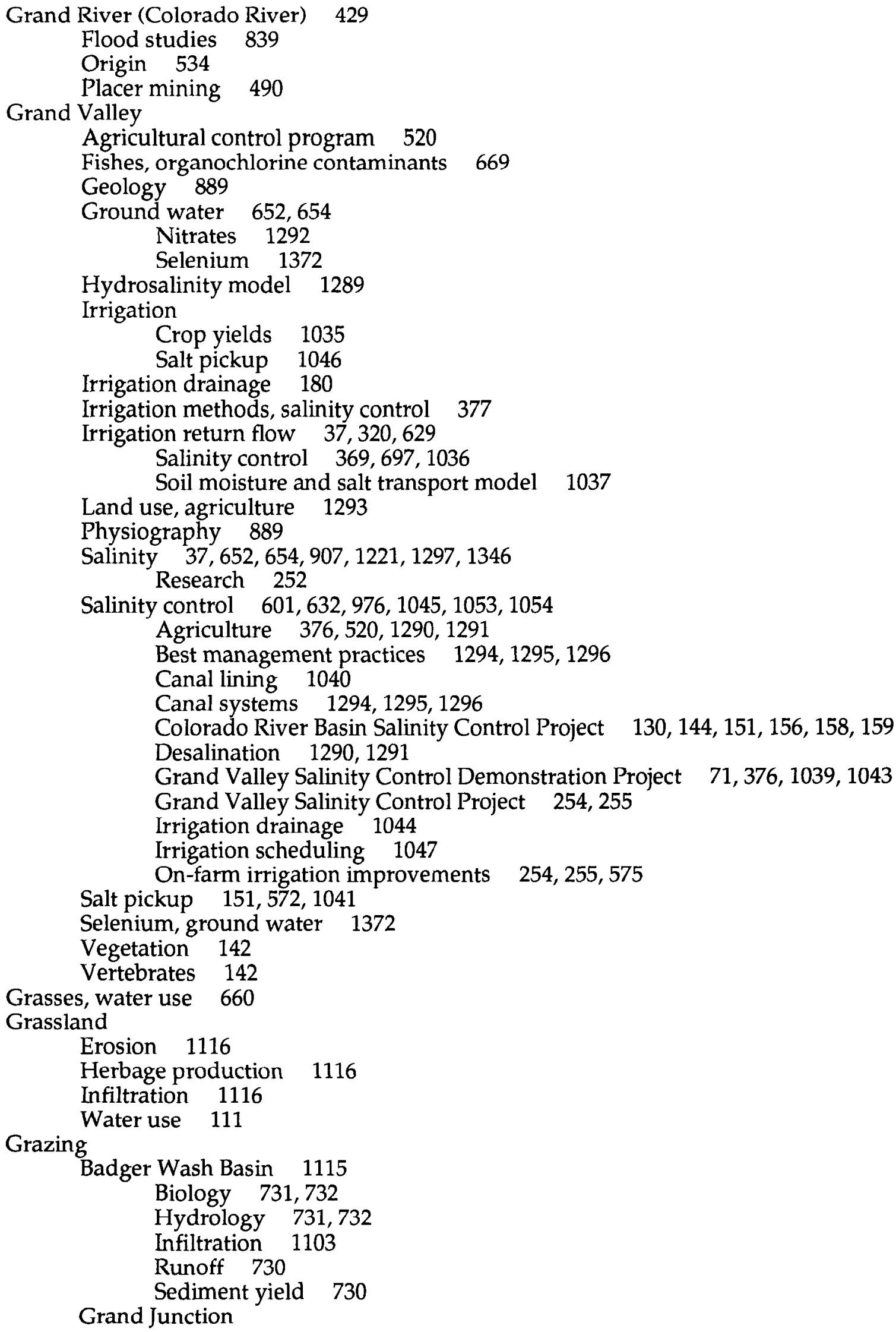




Biology 728
Hydrology 728
Infiltration 1027
Runoff 1027
Salinity 64, 1027
Sediment yield 1027

Green Mountain Reservoir 1102

Eutrophication 1167

Limnology $333,873,1167$

National Eutrophication Survey 1167

Nutrients 1167

Water marketing, environmental statement 161

Water pollution 1174

Nonpoint source 266

Water quality 102,333

Water releases, fish studies 944

Water sales 897

Gross Reservoir, phosphorus budget 670

Ground water 77, 439, 565, 573, 574, 781, 914, 1048, 1386, 1397

Alluvial aquifers 287, 1049

Appraisal 949

Aspen 114

Bibliography $36,425,1280$

Cattle Creek Basin, water quality and water supply 103

Classification 932

Coal 524, 604

Colorado-Big Thompson Project 12

Colorado Plateau, trace elements 592

Crested Butte 456

Water supply 1370

Crystal River Basin, water quality and water supply 103

Development, state regulations 598

Dissolved solids 389

East River Basin 456

Eisenhower Memorial Tunnel, Straight Creek tunnel site 566

Exploration, resistivity method 800

Fluoride 397

Geology 910

Gradients, wetlands 999

Granby Pump Canal 12

Grand Junction

Uranium mill tailings site 579,1139

Water supply 718

Grand Valley 652,654

Nitrates 1292

Selenium 1372

Gunnison 456

Exploration 800

Uranium mill tailings site $\quad 580,1140,1143$

Gunnison County 524, 1370

Gunnison River Basin 6, 108 Water quality data 1395

Hydrogeochemistry 744

Hydrologic models, flow 1396 
Leadville Limestone, water supply 1098

Levels data $104,105,319,321,322,741,1029,1030,1328$

Management 1087

Mancos Shale 317,318

Maps 1393

Aspen 114

Dissolved solids 389

Fluoride 397

Pitkin County 114

Temperature 969

McCoy 480

Water quality 456,968

Middle Park 1281

Mining, dewatering 726

Montrose County 283

Mount Emmons 1356

Nitrates 1292

Ohio Creek Basin 456

Piceance Basin 739

Pitkin County 114

Reports 1280

Risk assessment $\quad 579,580$

Rocky Mountain National Park 1334

Routt County 281

Saline water

Com irrigation 663

Crop irrigation requirements 662

Crop use 655,656

Wheat irrigation 657

Salinity $652,654,1311$

Flow 316

Irrigation 338,340

Transport modeling 31

Selenium 1372

Shadow Mountain National Recreation Area 1334

Spectrochemistry 744

State regulations 598

Stations index 956

Surface water, supply interrelationship $\quad \mathbf{5 8 5}$

Taylor River Basin 456

Temperature, maps 969

Uncompahgre River Valley 283,796

Selenium 1372

Water development 598

Water law 248, 776

Water pollution

Anvil Points Oil Shale Facility 978

Grand Junction uranium mill tailings site 579

Gunnison uranium mill tailings site $\mathbf{5 8 0}$

Water quality $509,510,565,573,574,1395$

Cattle Creek Basin 103

Crested Butte 456

Crystal River Basin 103

Data 1395 


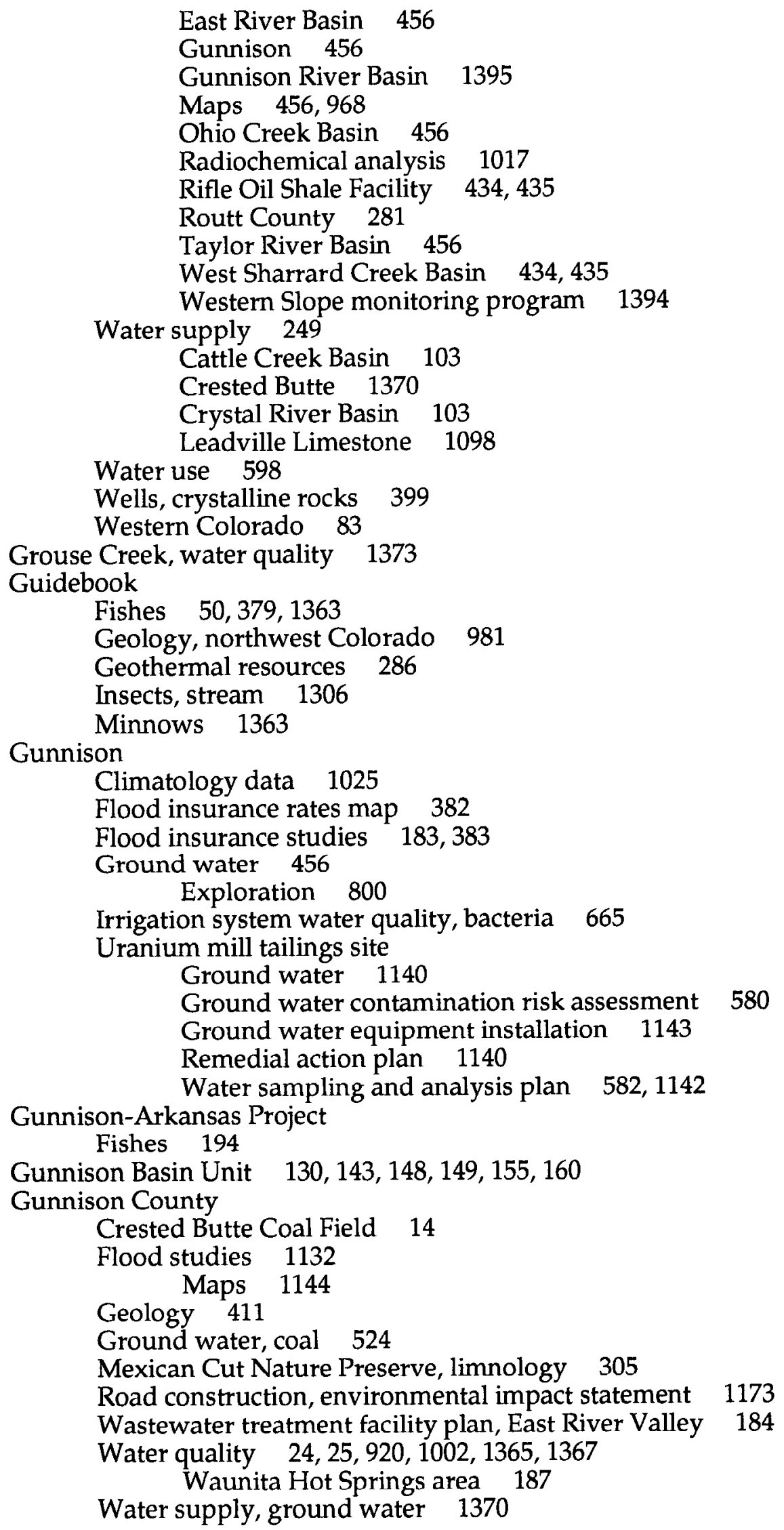


Gunnison Gorge

Climate change, bed-material entrainment $\quad 347$

Instream flow assessment 124

Resource management 346

Gunnison Gorge Wilderness Study Area

Hydrogeochemistry 117

Mineralogy 117

Gunnison River 91

AB Lateral hydropower project, effects on fluvial geomorphology 1076

Classification 234

Coal mining 1249

Dissolved solids 882

Ecosystem stability 1063

Effects of Aspinall Unit on fishes 770

Fish studies $52,861,867,868,869$

Abundance 1360

Distribution 1359, 1360

Effects of Taylor Park Reservoir 1352

Trout $53,862,863,869,945$

Flood studies $359,839,1126,1129,1131,1132$

Geology 564

Geomorphology 1076

Ice 165,827

Irrigation diversion effects 1359

Limnology 644

Stream regulation 1066

Mayflies (Ephemeroptera) 1307

Nonpoint source water pollution 266

Origin 534

Physiochemistry, dams 1065

Profile survey 519

Reservoir effects 1359

Salinity 1221

Salt load 638

Sedimentology 197,347

Stoneflies (Plecoptera) 643

Streamflow

Alteration 1063, 1359

Fish studies 52, 53, 869

Water diversion 56

Water quality $289,410,1002,1365,1367$

Measurements 638

Wild and scenic river study, environmental statement $\quad 850,854$

Gunnison River Basin 179, 1357, 1358

Atmospheric circulation 771

Bacteriology 1026

Climate change

Channel morphology 902

Geographic information systems (GIS) 47, 494

Hydrology 901, 902

Water resources $29,47,494$

Climatology data 29

Data generalization, hydrology

Feasibility study $504,505,506$ 
Geography 623

Ground water 6, 108

Water quality data

Hydrologic data 29, 885

Hydrology, drought 900

Irrigation 841

Land resources 258, 332

Macroinvertebrates, aquatic 888

Precipitation

Patterns 493

Simulation 495

Precipitation-Runoff Modeling System 664

Rainfall-runoff studies 208, 209

Reservoir surface area 330

Salinity control 130,841

Snowpack 771

Water hardness 1026

Water quality $289,851,884,885,888,1182,1365$

Ground water data 1395

Standards 234

Water resources 258, 332

Water use, irrigation 1277

Wetlands 841, 961, 962, 963

Gunnison River Valley, salinity 1346

Gunnison Tunnel 385, 758

Gunnison Waterworks, history 752,811

Gypsum, dissolution and transport, soils 458

Gypsum Creek, water quality 101, 1373

Habitat

Amphipods (Amphipoda), Rocky Mountains 1305

Endangered and threatened species, fishes 740, 1193, 1194

Endangered and threatened species, wildlife 1111

Fishes, sediment transport 936

Mapping, remote sensing 952

Native fishes 1273

Reservoirs 536

Riparian, ecology and management 204

Salmonid 868

Trout, Trout Cover Rating Method 1340

Vertebrate associations 168

Habitat alteration

Aquatic invertebrates 921

Energy development 523

Fishes 820

Endangered and threatened species $51,523,1391$

Habitat evaluation, wetlands 9

Habitat models, Physical Habitat Simulation Model (PHABSIM) $\quad 868,869$

Habitat monitoring

Colorado squawfish (Ptychocheilus lucius) 674, 1348, 1349, 1350

Humpback chub (Gila cypha) 674, 1349, 1350

Habitat requirements

Colorado River cutthroat trout (Salmo clarki pleuritcus) 88

Colorado squawfish (Ptychocheilus lucius) 501, 502, 531 streamflow 620 
Endangered and threatened species, fishes 615

Humpback chub (Gila cypha) 501, 502

Habitat separation, bugs, Hemiptera 306

Habitat suitability index curves, humpback chub (Gila cypha) 1272

Heat flow contours, maps 43

Heat flow data 294, 295

Hemiptera

Distribution 306

Habitat separation 306

Hensen Creek, water quality 1365

Historical geology 94,563

History

Black Canyon of the Gunnison National Monument 308

Colorado River Storage Project Act 1318

Gunnison Waterworks 752, 811

Water development 750

Western Slope 797

Homestake Creek

Runoff 406

Water quality 1373

Homestake Project Phase II, wetlands

Surface water hydrology 353

Water quality 354

Hot Sulphur Springs 906, 1070

Geology 84

Geothermal resource assessment 919

Humic substances

Deer Creek 790

Snake River 790

Humpback chub (Gila cypha)

Dissolved solids 933

Habitat monitoring $\quad 674,1349,1350$

Habitat réquirements $\quad 501,502$

Habitat suitability index curves 1272

Life history 1271

Limiting factors 501, 502

Monitoring program 768

Population 674, 1349, 1350

Recovery plan 1191

Recovery prospects 1271

Salinity 933

Status 121

Hunter Creek

Flood studies 1127

Water quality 231

Hunter-Fryingpan Wilderness Area

Geochemistry 832

Sediments 832

Hydrogeochemical data

Springs 42

Wells 42

Hydrogeochemistry

Acid-mine drainage $\quad 298,299$

Cimarron Spring 947 
Dotsero Springs 336

Glenwood Springs 336, 947

Ground water 744

Gunnison Gorge Wilderness Study Area 117

Hydrologic models 392

Mancos Shale 675, 677,678

Powderhorn Hot Springs 947

Springs 947

Hydrogeologic data 443, 1329

Drill-stem tests 1097

Piceance Basin 218

Regional Aquifer-Systems Analysis (RASA) 443

Hydrogeology $418,419,420,421,439,441,1096,1327,1386,1397$

Aquifers 708

West Sharrard Gulch 1049

Bibliography 908

Colony Shale Oil Project area 292

Colorado River Water Quality Improvement Program, Lower Gunnison Unit 143

Contaminant transport 951

Glenwood Springs 442

Leadville Limestone 442

Mountain sites, water pollution potential 417

Maps 422, 708, 1096

Naval Oil Shale Reserves 1113

Permeability 441

Aspen 115

Pitkin County 115

Piceance Basin 217

Porosity 441, 1342, 1343

Project Rulison 1282, 1285

Rapid Creek Basin 107

Hydrologic controls

Dissolved organic carbon 542

Salt load 445,446

Sediment 445,446

Hydrologic data $457,533,574,593,950$

Data sources 36

Gunnison River Basin 29,885

Maps 950

Parachute Creek 7

Parachute Creek Basin, Naval Oil Shale Reserves 427, 428, 903

Roan Creek 7

Streamflow 891

Surface water records 301

Index $337,437,1199$

Hydrologic models 206, 1259

Blue Mesa Reservoir 1078

Climate change 847

East River Basin 698

Water allocation 487

Colorado River Simulation System (CRSS) $\quad 282,450,1014$

Energy development impact 75

Ground water flow 1396

Hydrochemistry 392 
Mancos Shale, ground water and salinity 317

Mine drainage 216

Modular Hydrologic Modeling System (MHMS) 1005

Parachute Creek 1090

Piceance Basin 1090

Precipitation-Runoff Modeling System $\quad 664,698,883$

River management 591

River Simulation System (RSS) 1005

Roan Creek 1090

Salinity 591 Grand Valley 1289

Salinity flow 31, 193, 569

Streamflow forecasting 1300

Visualization techniques 496

Water quality, salinity 699,1289

Water resources management 75

Hydrologic monitoring, Rifle Oil Shale facility 329

Hydrology 957

Area 58, Northern Great Plains and Rocky Mountain coal provinces 196

Black Mesa 414

Coal, Interior Province, western region 70

Coal mining 543

Data generalization

$$
\text { East River Basin } 479
$$

Gunnison River Basin 479

De Beque, oil shale plant 199

Debris flows, implications 280

Delta County, coal lease tracts 106

East River Basin, climate change 772

Effects from grazing

Badger Wash Basin 731, 732

Grand Junction 728

Flood studies 590

Reservoir management 1275

Gunnison River Basin

Climate change $\quad 901,902$

Maps 1214

Drought 900

Mining effects 368

Naval Oil Shale Reserves 1113

Oil shale 1001

Oil shale development 1089,1298

Parachute Creek Basin 1092

Piceance Basin 1092

Stream regulation 1303

Streamflow data program evaluation $\quad 713$

Units map 1214

Vegetation cover, Boco Mountain 729

Vegetation zones 693

Wetlands

Crested Butte 276

Homestake Project Phase II 353

Montane and subalpine zone 311

Streamflow 1000 
Hydrostratigraphy 440

Subalpine zone 1000,1086

Hydrothermal resources 912, 915

Ice, Gunnison River 165,827

Infiltration

Capacity, Badger Wash Basin 1013

Grasslands 1116

Grazing 1027

Inorganics 1

Badger Wash Basin 1103

Aquatic biota 896

Sediments 896

Solutes 821

Insects, aquatic

Guidebook 1306

Trace elements $219,220,221$

Instream flow 858,1028

Assessment

Gunnison Gorge 124

Uncompahgre Basin Resource Area 124

Endangered and threatened species, fishes $1064,1122,1123$

Energy development 5

Models, Instream Flow Incremental Methology (IFIM) 869

Protection 192

Water law 987

Instream Flow Incremental Methology (IFIM) 869

Interior Province, western region, coal-hydrology program review 70

Interstate compacts 468,1326

Colorado River Compact $\quad 562,895,1318$

Upper Colorado River Basin Compact 1263

Invertebrates, aquatic 334

Investment planning model, salinity control 364

Ion exchange desalting, salinity control 97

Iron

Deer Creek 1099

Metal-mine drainage 823

Precipitation 1099

Snake River 58, 1099

Chemistry 784, 786

Transport 785

Iron Hill, water quality 973

Irrigation 1269

Arid lands and salinity, bibliography 191

Crop yield, Grand Valley 1035

Diversion effects on Gunnison River 1359

Gunnison River Basin 841

Water use 1277

Level-basin 658

Salt movement 195

Models 1259

Mountain meadows 653

On-farm improvements, salinity control $254,255,575$

Saline ground water

Corn 663 


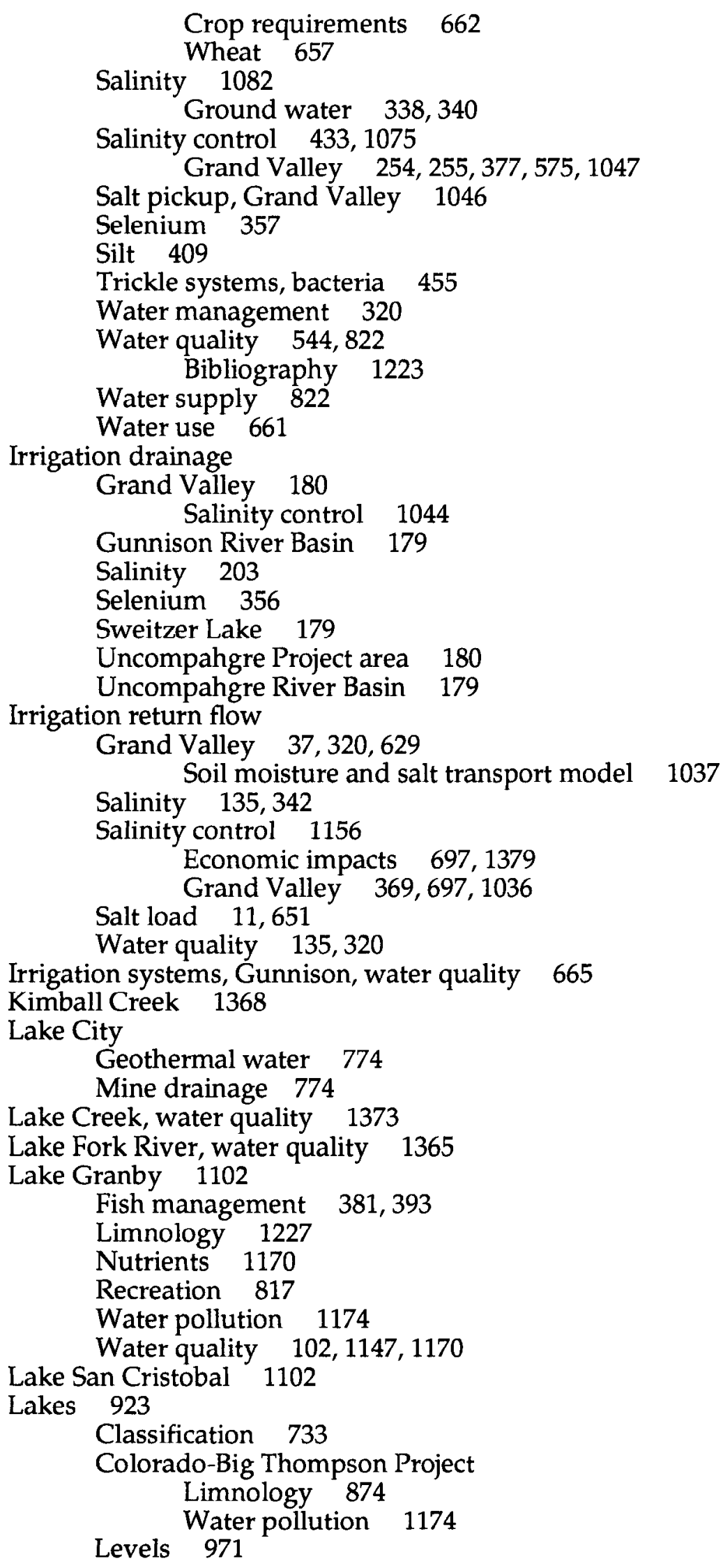


Plant ecology 599

Protozoa 334

Rocky Mountain National Park, sediments 887

Survey, fish distribution 702

Vegetation 600

Land reclamation, oil shale development $\quad 274,275$

Land resources 138,257

Colorado Salinity Control Project, Grand Valley Unit 144

Gunnison River Basin 258, 332

Impacts from oil shale development 1319

Land use

Upper Colorado River Basin 1261, 1262

Agriculture, Grand Valley 1293

Eutrophication, Dillon Reservoir 705

Maps 240

Oil shale development 1100

Leach Creek, flood studies 1129

Lead

Acid-mine drainage, ion exchange capture 298

Metal-mine drainage 823

Rocky Mountains, lake sediments 887

Leadville Limestone 509,510

Ground water supply, White River Uplift 1098

Hydrogeology 442

Leroux Creek, water quality 1367

Lewis Wash, flood studies 1129

Life history

Bonytail chub (Gila elegans) 1271

Colorado squawfish (Ptychocheilus lucius) 1018

Endangered and threatened species, fishes 615

Humpback chub (Gila cypha) 1271

Limnology 305

Bibliography 894

Blue Mesa Reservoir $\quad 80,291,1162,1164$

Colorado-Big Thompson Project reservoirs and lakes 874

Curecanti Unit 644

Dillon Reservoir 1160, 1165

Grand Lake 1166

Grand Mesa 922

Green Mountain Reservoir 333, 873, 1167

Gunnison River 644, 1066

Lake Granby 1227

Mexican Cut Nature Preserve 305

Shadow Mountain Lake 1166

Taylor Park Reservoir 1227

Lithium tracer, Snake River 60

Lithology 418 Salinity control 601

Little Salt Wash, flood studies 1131

Little Salt Wash Basin, rainfall-runoff studies 208, 209

Lower Gunnison Basin Unit 130, 143, 148, 149, 155, 160

Mack Wash, dissolved solids 882

Macroinvertebrates, aquatic

Amphipods (Amphipoda) 1305 


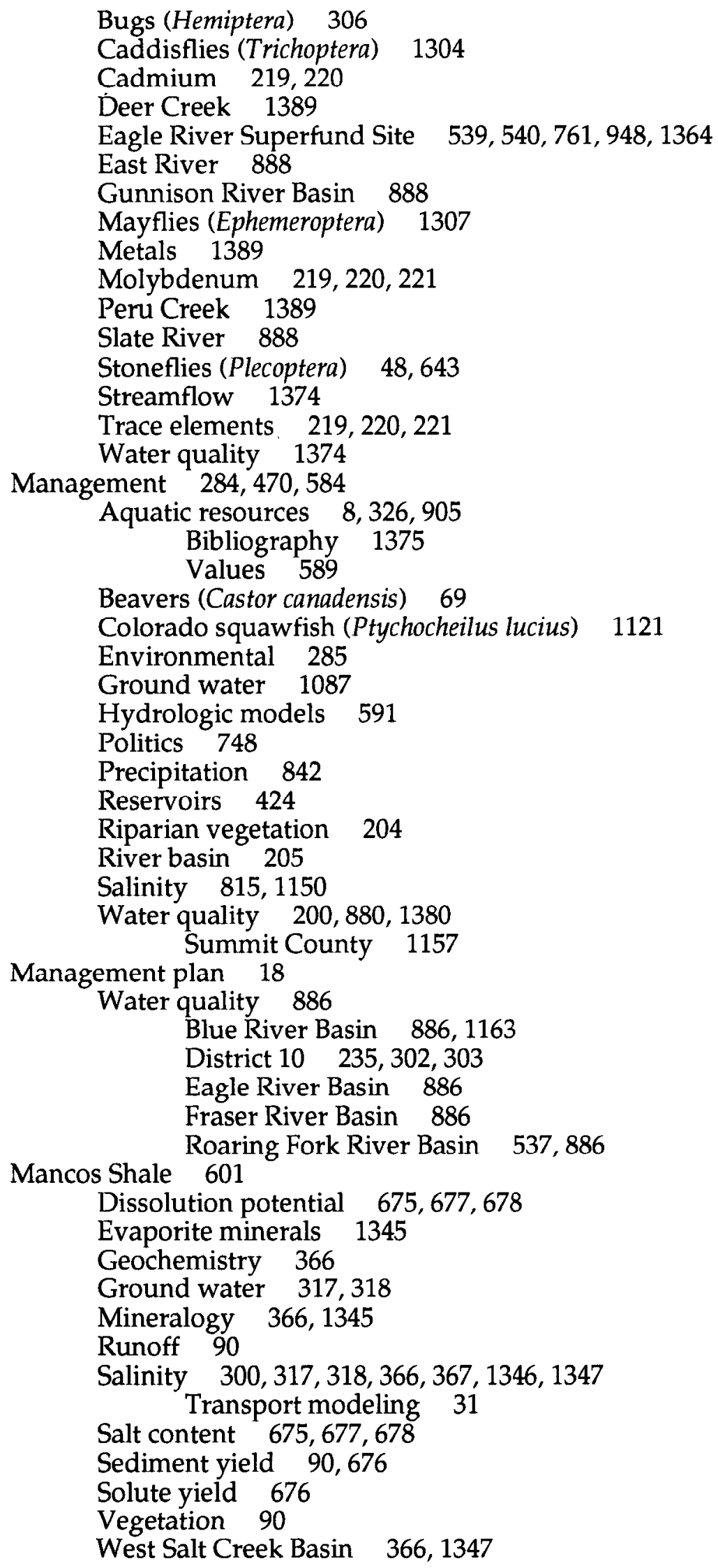




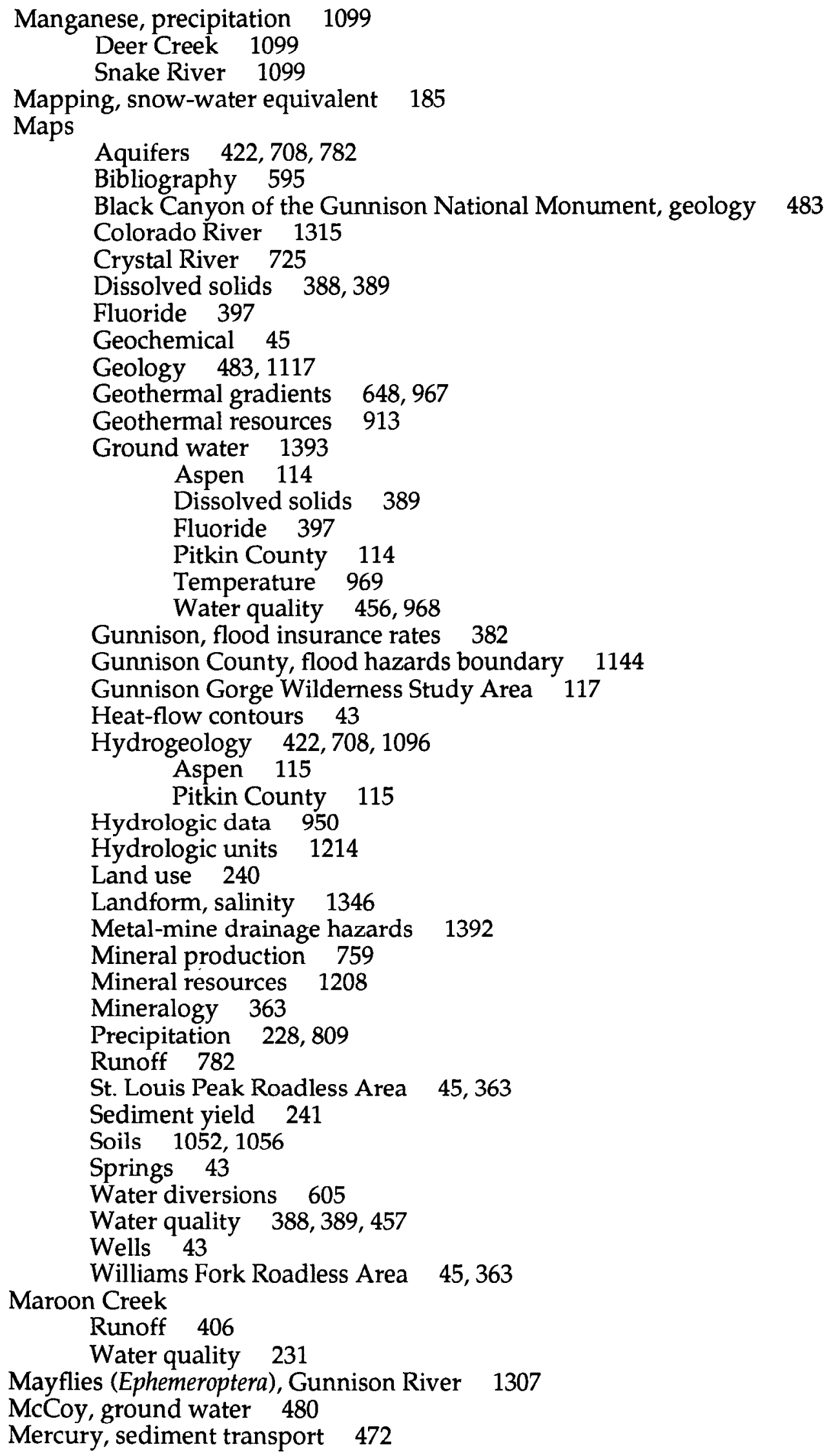


Mesa County

Coal mining, hydrology 107

Geology 889, 1009

Grand Junction uranium mill tailings site $328,579,581,1136,1137,1139,1141,1219$

Gunnison Gorge Wilderness Study Area 117

Oil resources 1324

Oil shale 1338

Physiography 889

Springs 567

Unaweep Canyon 717,719

Water quality 972

Project Rulison 682

Water resources 1324

Wells 567

Metals $1,992,1182$

Acid-mine drainage $\quad 298,299$

Precipitation 953

Aquatic biota $459,460,464,465,466,1389$

Black Gore Creek 1073

Colorado squawfish (Ptychocheilus lucius) $\quad 649,668$

Deer Creek 788, 790, 1389

Dillon Reservoir 757

Eagle River 1073

Fish studies $459,460,464,465,466$

Fishes, Curecanti National Recreation Area 666

Macroinvertebrates, benthic 1389

Mine drainage, precipitation 953,994

Peru Creek 757, 1389

Precipitation 788, 1099

Snake River 788, 790

Snake River Basin 757

Water pollution $\quad 459,460,464,465,466,757$

Meteorology 1321

Mexican Cut Nature Preserve, limnology 305

Microorganisms, Deer Creek 789

Middle Park

Geology 84

Ground water 1281

Mill Creek, water quality 101, 1373

Mine drainage (see also acid-mine drainage)

Geochemistry 941,942

Geology 941

Hazards map 1392

Hydrologic models 216

Lake City 774

Metals precipitation 953, 994

Piceance Basin, oil shale 1091

Treatment 1069, 1387

Water pollution $230,260,1387$

Slate River 1366

Mine spoils

Water quality 823,1339

Runoff 792

Water quality 792 
Mineral production, maps 759

Mineral resources 296, 1146, 1206, 1216, 1274

Bibliography 1015

Maps 1208

Metals 992

Occurrence 1208

Piceance Basin 1093

Public lands 940

Western Slope 30

Mineralogy

Gunnison Gorge Wilderness Study Area 117

Mancos Shale 366, 1345

St. Louis Peak Roadless Area 45

Salinity 367

Williams Fork Roadless Area 45

Mining

Copper 491

Hydrology 368

Mount Emmons, environmental impact statement 1195

Placer, Grand River $\quad 490$

Silver, dewatering $\quad 726$

Mining and milling operations

Nonmetallic 1016

Water pollution $229,461,462,463,464,467$

Minnows, guidebook 1363

Modular Hydrologic Modeling System (MHMS) 1005

Molybdenum

Blue River $\quad 617,618$

Dillon Reservoir 617,1160

Distribution 1284

Enrichment 1003

Geochemistry 618

In aquatic macroinvertebrates $219,220,221$

Occurrence 1284

Sediments 618

Tenmile Creek 617, 618, 701

Transport 617

Montane and subalpine zones

Riparian vegetation classification 34

Wetlands

Ecological characterization 1361

Hydrology 311

Vegetation 311

Montrose County

Gunnison Gorge Wilderness Study Area 117

Uncompahgre River Valley, ground water 283

Morrow Point Reservoir

Fish studies 1360

Mount Emmons

Water quality 102

Ground water 1356

Mining project, environmental impact statement 1195

Water quality 182

Mount Garfield Formation, salinity 1346 
Mountain Meadow Research Center

Climatology data 1025

Precipitation 659

Water use, grasses 660

Muddy Creek

Sediment discharge 998

Water quality 1367

Muddy Creek Basin, sediment 26

National Eutrophication Survey $1162,1164,1165,1166,1167$

National Water Assessment Model 798

National Water Assessment, Second 1244

National Water-Quality Assessment Program (NAWQA) 313

National resource information, bibliography 614

Natural resource lands, salinity control 120

Naval Oil Shale Reserves

Hydrogeology 1113

Hydrologic data 427, 428, 903

Hydrology 1113

Nickel, metal-mine drainage 823

Nitrates, ground water 1292

Nitrogen 1162, 1164, 1165, 1166, 1167

Nonpoint source water pollution $265,266,878,1021$

Dillon Reservoir trading program 352,1337

Salinity $38,78,342,1011,1021$

Salinity control 601,976

North Beaver Creek, water quality 24, 25

Nutrients

Blue Mesa Reservoir $\quad 1162,1164$

Dillon Reservoir 826, 1160, 1165

Grand Lake 1166, 1170

Green Mountain Reservoir 333, 1167

Lake Granby 1170

Nitrogen 1162, 1164, 1165, 1166, 1167

Phosphorus $670,808,1162,1164,1165,1166,1167$

Loading 806

Shadow Mountain Lake 1166,1170

Oh-Be-Joyful Creek, water quality 823,1002

Ohio Creek, water quality 182

Ohio Creek Basin, ground water 456

Oil resources

Delta County 1324

Mesa County 1324

Oil shale 226, 1338

Aquatic biota 1001

Bibliography 118,979

Environmental references 990

Colony Shale Oil Project area, hydrogeology 292

Energy use 995

Environmental analysis 517

Environmental studies 990

Hydrology 1001

Piceance Basin 1093

Mine drainage 1091

Pollution 931 
Production, environmental planning 288

Waste 931

Water pollution 1301, 1302

Water quality 1072

Water requirements for stabilization 1376

Water demand 395

Water pollution 931

Water quality $434,435,1001$

Water supply 395

Water use 995

Salinity management 955

Oil shale development 765,1100

Aquatic ecosystems 801

Colony Shale Oil Project 499

Economics 473

Environmental study 1107

Environmental impact statement 119,122

Hydrologic information needs 1089

Hydrologic problems 1298

Impacts on land resources 1319

Land disturbance effects 751

Land reclamation $\quad 274,275$

Land use 1100

Leasing program

Economics and environmental protection 239

Environmental statement 1145

Parachute Creek, environmental baseline program 49

Surface water-quality parameters 635

Water quality 801

Water supply 297, 779, 1286

Water use 473

Oil shale plants

Anvil Points

De Beque

Soil contamination 978

Water pollution 978

Geology 199

Hydrology 199

Parachute Creek

Environmental impact analysis $\quad 225,227$

Environmental setting 1107

Rifle

Hydrologic monitoring 329

Water quality 434,435

Water use and reuse 355,516

Organics, Green Mountain Reservoir 333

Organochlorine contaminants

Colorado squawfish (Ptychocheilus lucius) 668

fishes, Grand Valley 669

Orographic-Precipitation Model

East River Basin 698

Gunnison River Basin 495

Orvis Hot Spring 1310

Ouray 
Geothermal energy 214

Geothermal resources assessment 1382

Springs 272

Ouray Hot Springs 906,1310

Overland flow, salt pickup 943

Palisade, flood studies 1130

Paonia Project, Colorado River Storage Project, benefit/impact reappraisal 1134

Paonia Reservoir

Sedimentation 26

Water quality 102

Parachute Creek

Alluvium 1335

Aquatic biology, environmental impact analysis 398

Colony Shale Oil Project, environmental study 1107

Dissolved solids 882

Flood studies 1055

Hydrologic data 7

Hydrologic models 1090

Oil shale development, environmental baseline program 49

Parachute Creek Basin

Hydrology 1092

Naval Oil Shale Reserves, hydrologic data 427, 428, 903

Precipitation-Runoff Modeling System 883

Springs

Discharge 175

Water quality 175

Parachute Creek oil shale plant, environmental impact analysis 225, 227

Parachute Creek Valley, environmental setting 1106

Parshall, geology 84

Peru Creek

Macroinvertebrates, benthic 1389

Metals 757, 1389

Restoration 1388

Pesticides 2

Water quality $101,823,1388$

Bibliography, irrigation water quality 1223

Water quality 1232

Petroleum hydrocarbons, Colorado squawfish (Ptychocheilus lucius) 668

Phosphorus 808

Budget

Gross Reservoir 670

Williams Fork Reservoir 670

Loading 806

Phreatophytes 1239

Bibliography 1239

Water use 1239

Physical aspects, Upper Colorado River Basin 76, 341

Physical Habitat Simulation Model (PHABSIM) 868, 869

Physiochemistry, Gunnison River, dams 1065

Physiography 937

Black Canyon of the Gunnison National Monument 484

Grand Valley 889

Mesa County 889

Picea, water use 111 
Picea engelmanni, evapotranspiration 454

Piceance Basin

$\begin{array}{lll}\text { Alluvium } 1335 & \\ \text { Aquifers } 739 & & \\ \text { Ground water } 739 & \\ \text { Hydrogeologic data } & 218 \\ \text { Hydrogeology } 217 & \\ \text { Hydrologic models } & 1090 \\ \text { Hydrology 1092 } & \\ \text { Mineral resources } & 1093 \\ \text { Oil shale 1093 } & \end{array}$

Mine drainage 1091

Parachute Creek 1090

Roan Creek 1090

Sediment chemistry 791

Unconsolidated deposits 1335

Water resources 1093

Piceance Creek Basin, fish studies 930

Pitkin County

Geology 411, 526

Ground water 114

Hunter-Fryingpan Wilderness Area 832

Hydrogeology, permeability 115

Porphyry Mountain Wilderness Study Area 832

Smuggler Mountain 1171

Water quality 101

Management plan 886

Pitkin Creek, water quality 1373

Planning 172, 415, 1316

Blue Mesa Reservoir 1109

Environmental 1118

Oil shale production $\quad 288$

Salinity control 743

U.S. Department of Agriculture 513

Plant ecology, lakes 599

Plateau Creek, water quality 202

Plecoptera

Gunnison River 643

Rocky Mountains 48

Polonium 1004

Populus 1050

Populus tremuloides

Evapotranspiration $\quad 454$

Water use 111

Porphyry Mountain Wilderness Study Area

Geochemistry 832

Sediments 832

Powderhorn, water quality 24, 25, 973

Powderhorn Hot Springs 378 Hydrogeochemistry 947

Precipitation 228, 307, 574, 667, 753, 754, 937, 975, 1007, 1010

Frequency 809

Management 842

Maps 228, 809 
Monthly summary 63

Mountain Meadow Research Center 659

Patterns 515

Gunnison River Basin 493

Project Rulison, radiochemical analysis 202,1283

Runoff 825

Simulation, Gunnison River Basin 495

Precipitation (geochemistry), metals 788, 1099

Acid-mine drainage 953

Mine drainage 953,994

Precipitation-Runoff Modeling System

East River Basin 664,698

Gunnison River Basin 664

Parachute Creek Basin 883

Project Rulison

Geology 1282, 1285

Hydrogeology 1282, 1285

Precipitation, radiochemical analysis $\quad 202,1283$

Reservoirs, radiochemical analysis 682

Springs 567

Radiochemical analysis $\quad 682,1283$

Water quality, radiochemical analysis $202,682,1283$

Wells 567

Project Skywater 131

Radiochemical analysis $\quad 682,1283$

Protozoa 334

Ptychocheilus lucius

Colorado River "15-mile reach" $\quad 620,897,898$

Decline 619

Stream regulation 1119

Dissolved solids 933

Ecology 1018, 1121

Habitat monitoring $674,1348,1349,1350$

Habitat requirements $501,502,531$

Streamflow 620

Heavy metal analysis 649

Larval distribution 500

Life history 1018

Life strategies 1120

Limiting factors 501, 502

Management 1121

Metals 649,668

Monitoring program 768

Organochlorine contaminants 668

Petroleum hydrocarbons 668

Population 674, 1348, 1349, 1350

Recovery plan 1192

Salinity 933

Tolerance 871

Status 121

Streamflow 620,769

Public health

Battlement Mesa Project 1240

Dallas Creek Water Project 1231 
Public lands

West Divide Project 1234,1235

Mineral deposits 940

Mineral environmental assessment 940

Salinity 64,578

Salinity control 120,123

Pulp mills, water pollution 899

Quartz Creek, water quality 289, 1365

Radiation 2

Radioactive contaminants, water quality 1232,1242

Radioactivity

Springs 181,703

Uranium mill tailings 1176

Radiochemical analysis, Project Rulison $\quad 202,682,1283$

Radium 1004

Bottom sediments 1229

Doughty Springs 507

Radium Monitoring Network 1158, 1242

Radium-226, water quality 1158, 1242

Radon-222 585

Water quality 1241

Rainbow trout (Salmo gairdneri), Black Canyon of the Gunnison National Monument 869

Rainfall, peak flow data 345

Rainfall-runoff studies

Gunnison River Basin 208, 209

Little Salt Wash Basin 208, 209

Salt Creek Basin 208, 209

Rainfall, Upper Limit Design Rain Storm (ULDRS) 828

Rapid Creek Basin

Coal mining, hydrologic effects 107

Hydrogeology 107

Razorback sucker (Xyrauchen texanus), Colorado River "15-mile reach" 897, 898

Reclamation $386,387,877$

Streams, acid-mine drainage 965

Uncompahgre Project 113

Recovery implementation program, endangered and threatened species, fishes 1188

Recovery plan

Bonytail chub (Gila elegans) 1190

Colorado squaw fish (Ptychocheilus lucius) 1192

Recreation 997

Humpback chub (Gila cypha) 1191

Blue Mesa Reservoir 1109

Lake Granby 817

Shadow Mountain Lake 817

Red Mountain Creek, water quality 823

Red Mountain District, springs 272

Redsandstone Creek, water quality 1373

Redside shiner (Richardsonius balteatus (richardson)), distribution 503

Reed Wash

Dissolved solids 882

Flood studies 1131

Regional Aquifer-Systems Analysis (RASA) 418, 419, 420, 421, 422, 439, 440, 441, 442, 443, $1094,1095,1096,1343,1386,1390,1396,1397$

Hydrogeologic data 443 
Regional residuals environmental quality management (REQM) modeling, salinity 87 Remedial action

Eagle Mine Site 1172

Smuggler Mountain 1171

Remedial action plan, uranium mill tailings site

Grand Junction 1136, 1137, 1139

Gunnison 1140

Rifle 1138

Remote sensing

Gunnison River Basin

$$
\text { Irrigation water use } 1277
$$

Reservoir surface area 330

Habitat mapping 952

Snowpack 611,612, 613

Snow-water equivalent mapping 185

Reservoir operations, Blue Mesa Reservoir, ecology 594

Reservoirs 762, 1068, 1102

Classification 733

Colorado-Big Thompson Project

Limnology 874

Effects on

Water pollution 1174

Downstream channel and water quality 178

Gunnison River 1359

Gunnison River, limnology 644

Gunnison River Basin, surface area 330

Habitat 536

Management 424

Flood studies 1275

Monitoring report, Denver Water Department 982

Project Rulison area, radiochemical analysis 682

Recreation 817

Salinity 423

Storage 892

Water releases

Fish studies 944

Sediment removal 365

Resource development 1261, 1262

Resource management 32

Gunnison Gorge 346

Rhodamine WT dye, stability 61

Richardsonius balteatus (richardson), distribution 503

Ridgway Reservoir, inorganics

Aquatic biota 896

Sediments 896

Rifle Gap Reservoir, water quality 102

Rifle Oil Shale Facility

Hydrologic monitoring 329

Water quality 434,435

Rifle uranium mill tailings site

Environmental impact statement 1138

Remedial action 1138

Rio Blanco County

Water sampling and analysis plan $\quad 583$ 
Grand Hogback Coal Field 15

Ground water, Leadville Limestone 1098

Oil shale 1338

Piceance Creek Basin, fish studies 930

Riparian vegetation $893,1050,1325$

Classification 641

Montane and subalpine zones 34

Ecology and management 204

Fire, water and salinity relations 171

Water law 1325

Wetlands 640

Risk assessment

Glenwood Springs 799

Ground water contamination

Grand Junction uranium mill tailings site 579

Gunnison uranium mill tailings site 580

River basin, management 205

River Simulation System (RSS) 1005

River system development

Colorado Plateau 723

Rocky Mountains 723

Road Beaver Creek, water quality 24, 25

Road construction, environmental impact statement 1173

Roan Creek

Dissolved solids 882

Ecosystem study 1368

Flood studies 1055

Hydrologic data 7

Hydrologic models 1090

Nonpoint source water pollution 266

Sediment chemistry 791

Roan Creek Basin, springs

Discharge 175

Water quality 175

Roaring Fork River

Dissolved solids 882

Fish studies, trout 865,866

Flood studies 1127

Geology 526

Nonpoint source water pollution 266

Runoff 406

Water quality $101,231,410$

Roaring Fork River Basin, water quality management plan $\quad 537,886$

Roaring Fork River Valley, geology 411

Robinson Creek, water quality 1367

Rock Creek, sediment discharge 177

Rock Creek Reservoir 857

Water quality and downstream channel effects 178

Sedimentation 177

Rocky Mountain National Park

Fisheries and aquatic management 993

Ground water 1334

Lake sediments, $210 \mathrm{~Pb} \quad 887$

Water supply, Harbison Meadow campground site 1279 
Rocky Mountains

Amphipods (Amphipoda) 1305

Geothermal studies 293

Regulated streams 1385

River system development 723

Runoff 406

Stoneflies (Plecoptera) 48

Stream regulation, caddisflies (Trichoptera) 1304

Watershed management 693,694

Wetlands 277

Ecological characterization 1361

Rocky Point Pumped Storage Project, environmental report 857

Rocky Point Reservoir 857

Routt County

Ground water, water quality 281

Water quality 101

$$
\text { Management plan } 886
$$

Ruedi Dam, geology 879

Ruedi Reservoir

Geology 879

Water quality 102

Water sales 897

Runoff $323,646,727,855,1010,1084,1288$

Badger Wash Basin 727, 730, 1013

Grazing 1027

Badger Wash Basin 730

Mancos Shale 90

Maps 782

Mine spoils 792

Precipitation 825

Rocky Mountains 406

Snowmelt $222,345,1020$

Solute pickup 679

West Salt Creek Basin, salt load 1084

St. Louis Peak Roadless Area

Geochemical data 46

Geochemical maps 45

Mineralogy maps 363

Saline water

Energy development 146

Ground water

Corn irrigation 663

Crop requirements 662

Crop use 655, 656

Survey 647

Wheat irrigation 657

Water use $67,99,146$

Transport systems 766

Salinity $35,78,130,139,152,179,180,312,371,423,518,530,608,609,636,673,686,707,808$, $812,833,835,836,882,960,980,996,1027,1051,1148,1149,1151,1152,1269,1353$

Agriculture 432

Acreage reduction $\quad 557$

Agronomics 1377

Economics 1377 
Alluvium $675,677,678$

Bibliography

Arid lands irrigation 191

Irrigation water quality 1223

Water quality 807

Bonytail chub (Gila elegans) 933

Colorado River Basin Salinity Control Project, Grand Valley Unit $\quad$ 130, 144

Colorado River Water Quality Improvement Program, Lower Gunnison Unit

Colorado squawfish (Ptychocheilus lucius) 933

Tolerance 871

Cost-benefit analysis 559

Diffuse sources 1011

Discharge 837

Dotsero Springs 1266

Economic impacts $559,642,716,1149$

Endangered and threatened species, fishes 933

Energy 400, 402

Energy development 404

Erosion 1051

Economic evaluation

Geology 1346

Glenwood Springs 1266

Grand Valley $37,652,654,907,1221,1289,1297,1346$

Hydrologic models 1289

Grazing 1027

Ground water $652,654,1311$

Irrigation 338,340

Transport modeling 31

Gunnison River 1221

Gunnison River Valley 1346

Humpback chub (Gila cypha) 933

Hydrologic models 591

Grand Valley 1289

Water quality 699,1289

Irrigation 1082

Irrigation drainage 203

Irrigation return flow 135,342

Landform 1346

Maps 1346

Major ions 836

Mancos Shale 300, 317, 318, 366, 367, 675, 677, 678, 1346, 1347

Mount Garfield Formation 1346

Nonpoint source water pollution $38,78,342,1011,1021$

Public lands 64,578

Regional residuals environmental quality management (REQM) modeling 87

Sediment 1051

Sego Formation 1346

Springs 300,1266

Stochastic analysis $\quad 745$

Stochastic model 746

Water pollution 1154

Water quality $763,1148,1149,1152,1232$

Hydrologic models 699,1289

Standards $244,245,246,247,262$ 
Water resources $396,400,402$

West Salt Creek Basin 1347

Salinity control $130,606,627,628,1051,1081,1150,1185,1186,1259,1341$

Agriculture 253, 376, 431, 520

Agronomics 1378

Economics 1378

Best management practices $1294,1295,1296$

Canal systems 1294, 1295, 1296

Colorado River Basin Salinity Control Act $529,763,1133$

Colorado River Basin Salinity Control Program 1135

Colorado River Basin Salinity Control Project, Grand Valley Unit $\quad 130,144,151,156$, 158,159

Colorado River Salinity Control Program 938

Colorado River Water Quality Improvement Program 130, 141, 149, 150, 164, 607, 830

Diffuse sources 601

Dotsero Springs $130,738,1058$

Economic benefits 1150

Economic incentives 556

Energy 403

Federal Water Pollution Control Act 68

Geomorphology 601

Glenwood Springs 130, 738, 1058

Grand Valley 71, 601, 632, 976, 1045, 1053, 1054

Agriculture 376, 520, 1290, 1291

Best management practices 1294, 1295, 1296

Canal lining 1040

Canal systems $1294,1295,1296$

Desalination 1290, 1291

Irrigation drainage 1044

Irrigation methods 377,575

Irrigation return flow 369,697, 1036

Irrigation scheduling 1047

On-farm irrigation improvements $254,255,575$

Grand Valley Salinity Control Demonstration Project 71, 369, 376, 1039, 1043

Gunnison River Basin 130, 841

Implementation plan 244

Investment planning model 364

Ion exchange desalting $\quad 97$

Irrigation 433, 1075

Irrigation methods 377,575

Irrigation return flow 1156

Economic impacts 697,1379

Lithology 601

Grand Valley $369,697,1036$

Lower Gunnison Basin Unit $130,143,148,149,155,160$

Marginal cost analysis $372,373,374,375$

Natural resource lands 120

Nonpoint source water pollution 601,976

On-farm irrigation improvements $254,255,575$

Planning 513, 743

Public lands 120,123

Springs 738,1058

U.S. Department of Agriculture planning process 513

Water policy 433,1075 
Salinity flow

Water quality 1062

Ground water 31,316

Hydrologic models 31, 193, 569

Level-basin irrigation 195

Salinity management $\quad 19,602,603,742,815,1150,1278,1351$

Colorado River Basin development 173

Oil shale water supply 955

Salt gradient ponds 561

Water resource development $\quad 174$

Salinity monitoring, Utah 477

Salinity policy 1042

Salinity research, Colorado State University, Grand Valley 252

Salix, fire, water and salinity relations 171

Salmo clarki pleuriticus

Habitat 1340

Requirements 88

Status 121

Salmo gairdneri, Black Canyon of the Gunnison National Monument 869

Salmo trutta

Black Canyon of the Gunnison National Monument 869

Habitat 1340

Salmonid 870

Population dynamics, Taylor River 864

Habitat 868

Salt Creek Basin, rainfall-runoff studies 208, 209

Salt dissolution and transport, soils 458

Salt gradient ponds, economic models 561

Salt load $95,96,638,1012,1084$

Agriculture 315

Geology 315

Geomorphology $444,445,446,447$

Gunnison River 638

Hydrologic controls 445,446

Irrigation return flow 11,651

Sediment 1021

West Salt Creek Basin, runoff 1084

Salt pickup

Grand Valley $151,572,1041$

Irrigation 1046

Overland flow 943

Salt storage, alluvium 498

Salt transport model, Grand Valley 1037

Salt Wash, dissolved solids 882

Salvelinus fontinalis, habitat 1340

Sediment 139, 469, 573, 574, 646, 727, 1012

Adsorption, acid-mine drainage 735

Bed-material entrainment 347

Bottom

Gunnison River Basin 179

Irrigation drainage 179

Radium 1229

Sorption, acid-mine drainage 736

Sweitzer Lake 179 
Uncompahgre River Basin 179

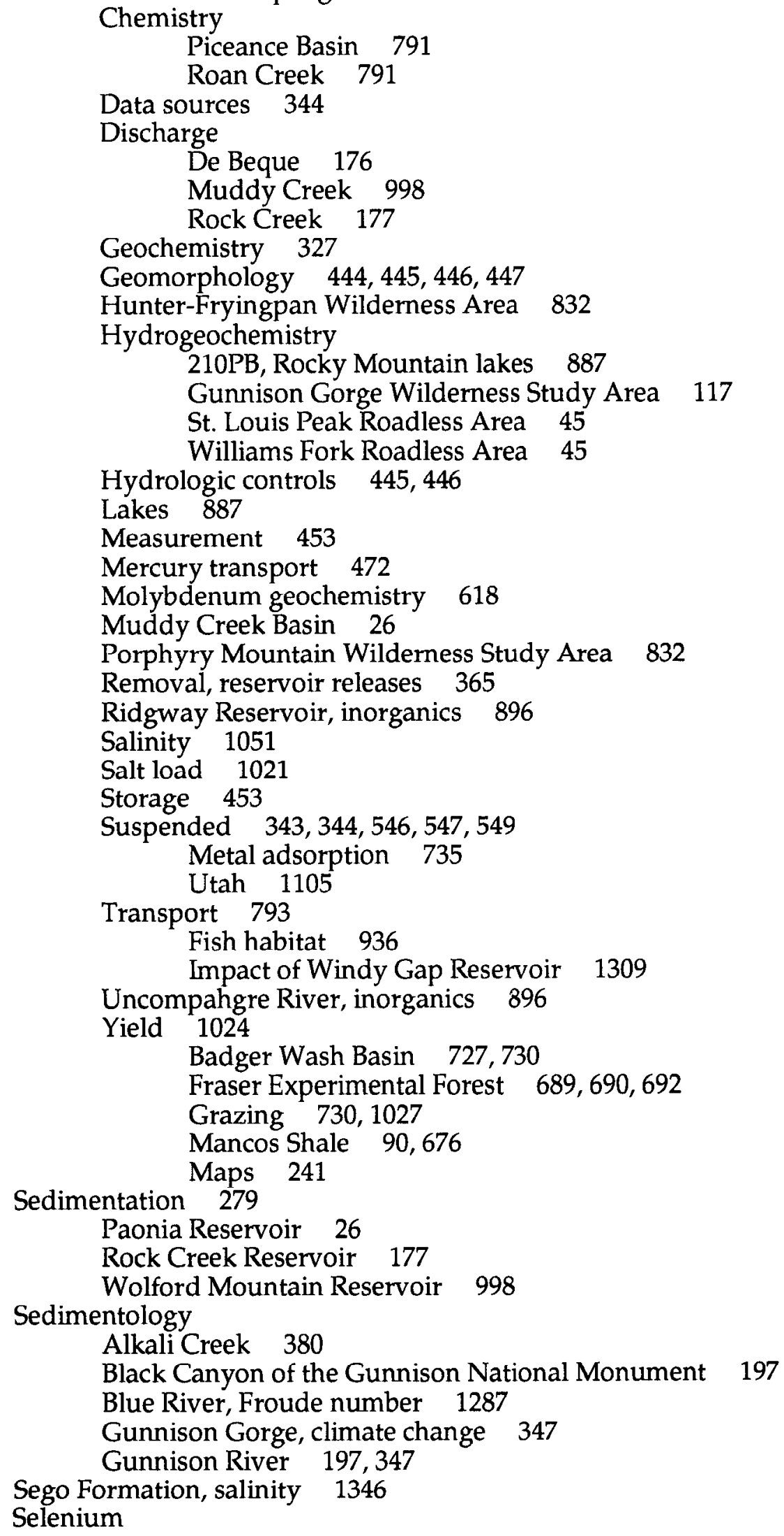

Chemistry 
Agriculture 20

Vegetation 408

Grand Valley 1372

Ground water 1372

Irrigated lands 357

Irrigation drainage 356

Occurrence 1354

Soils 408

Uncompahgre River Valley 1372

Water quality 408

Sewage treatment plants

Effluent, Slate River 1366

Waste load allocation 780
Eagle River 780

Gore Creek 780

Shadow Mountain National Recreation Area, ground water 1334

Shadow Mountain Lake 1102

Eutrophication 1166

Fish management 381

Limnology 1166

National Eutrophication Survey 1166

Nutrients 1166, 1170

Recreation 817

Water pollution 1174

Water quality $102,1147,1170$

Silt, irrigation 409

Silver 593

Slate River

Macroinvertebrates, aquatic $\quad 888$

Water pollution 1366

Nonpoint source 266

Water quality $182,289,290,304,410,823,888,1002,1365$

Smuggler Mountain

Remedial action 1171

Superfund Enforcement Decision 1171

Snake River

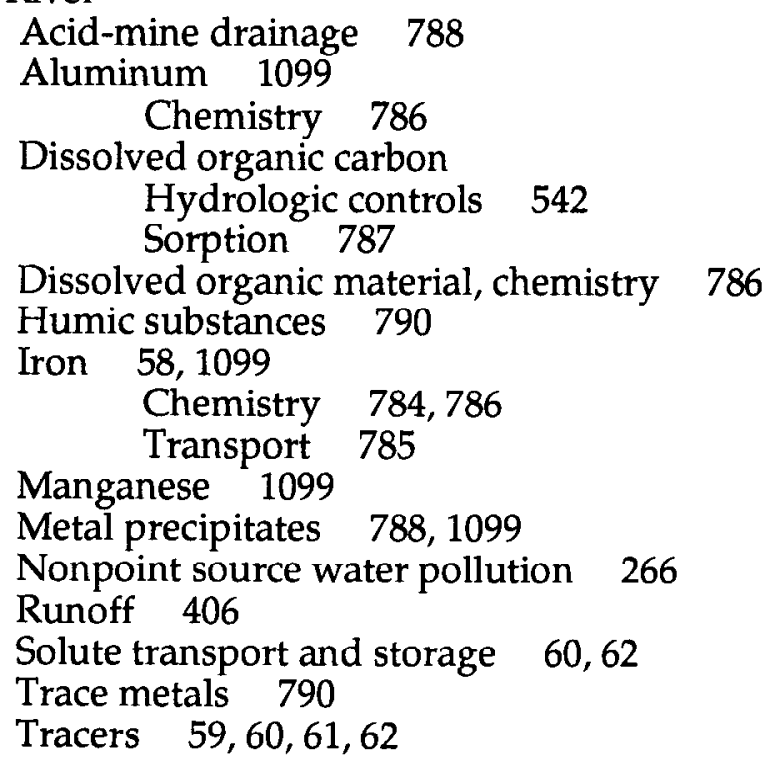

Dissolved organic carbon Hydrologic controls 542 Sorption 787

Dissolved organic material, chemistry $\quad 786$

Humic substances 790

Iron 58, 1099

Chemistry 784,786

Transport 785

Manganese 1099

Metal precipitates 788,1099

Nonpoint source water pollution 266

Runoff 406

Solute transport and storage 60,62

Trace metals 790

Tracers $59,60,61,62$

264 Bibllography, Indices, and Data Sources of Water-Related Studies, Upper Colorado River Basin, Colorado and 
Water quality 101,823

Snake River Basin, metals 757

Snow 1313, 1314

Water pollution, oil shale waste 1302

Snow-water equivalent, mapping 185

Snowmass Creek, water quality 231

Snowmass Water and Sanitation District, wastewater treatment facility, environmental impact statement 1330

Snowmelt

Eagle River Basin, air temperature 1383

Fraser Experimental Forest 436,691

Water supply 691

Runoff 222, 345, 1020

Snowpack $358,413,855,1333$

Assessment of augmentation 1331,1332

Environmental assessment 488

Gunnison River Basin 771

Herbage production 413

Remote sensing 611,612, 613

Sodium 388

Streamflow 110, 413

Soil moisture recharge 358

Soils

Badger Wash Basin 1115

Contamination, Anvil Points Oil Shale Facility 978

Geochemistry 327

Grand Junction uranium mill tailings site

1141

Gypsum, dissolution and transport 458

Maps 1052, 1056

Moisture and salt transport model, Grand Valley 1037

Selenium 408

Survey 1057

Uncompahgre Project area, trace elements 1077

Solute loading 980

Solute pickup 679

Solute transport and storage, Snake River $\quad 60,62$

Solute yield, Mancos Shale 676

Solutes, inorganic, water quality 821

Spectrochemistry, ground water 744

Springs $65,250,449,508,541,906,1070,1299,1310,1312$

Appraisal 704

Avalanche Springs 1070,1310

Basic data 81

Canon Creek Springs 906

Cebolla Hot Springs $838,1070,1310$

Water quality 391

Cement Creek Spring 1070, 1310

Cimarron Spring 378

Hydrogeochemistry 947

Conundrum Spring 1310

Delta County 181

Dotsero Springs 1070, 1310

Energy development, water use 335

Hydrogeochemistry 336 
Salinity 1266

Salinity control $130,738,1058$

Water quality 336

Doughty Springs 507

Garfield County 567

Geology 671

Glenwood Springs $\quad 378,1070,1310$

Aquifer tests 442

Energy development, water use 335

Hydrogeochemistry 336, 947

Salinity 1266

Salinity control 130, 738, 1058

Water quality 336

Hot Sulphur Springs $\quad 906,1070$

Geology 84

Geothermal resource assessment 919

Hydrogeochemical data 42

Hydrogeochemistry 947

Maps 43

Mesa County 567

Orvis Hot Spring 1310

Ouray 272

Geothermal resource assessment 1382

Ouray Hot Springs 906, 1310

Parachute Creek Basin

Discharge 175

Water quality 175

Powderhorn Hot Springs 378

Hydrogeochemistry 947

Project Rulison area 567

Radiochemical analysis $\quad 682,1283$

Radioactive 181, 703

Radium 507

Red Mountain District 272

Roan Creek Basin

Discharge 175

Water quality 175

Salinity 300,1266

Salinity control 738,1058

Tomichi Hot Springs 906

Uncompahgre Springs 906

Waunita Hot Springs 1070, 1310

Geothermal resource assessment $\quad 838,1381$

Water quality 187,391

Spruce (Picea), water use 111

Statistical tests, basin response 824

Stoneflies (Plecoptera)

Gunnison River Basin 643

Rocky Mountains 48

Straight Creek Tunnel site, Eisenhower Memorial Tunnel, ground water 566

Stream channels

Reservoir effects

Rock Creek Reservoir 178

Wolford Mountian Reservoir 178 
Tomichi Creek, fish studies 166

Stream measurement 525

Stream regulation

Algae 314

Aquatic biota 1303

Caddisflies (Trichoptera), Rocky Mountains 1304

Colorado squawfish (Ptychocheilus lucius) decline 1119

Gunnison River 1066

Hydrology 1303

Temperature 1303

Streambed, metal sorption 736

Streamflow $189,324,358,637,707,818,819,835,855,891,937,971,974,1079,1202,1205,1211$, $1250,1251,1252,1253,1254,1255,1256,1257$

Alteration

Effects on fish and wildlife $362,872,875,876,1322,1374$

Effects on macroinvertebrates, aquatic 1374

Gunnison River 1063, 1359

Black Canyon of the Gunnison National Monument 869

Fish studies 53

Trout 869

Blue River, Froude number 1287

Climate change $846,847,848$

Colorado-Big Thompson Project 672

Cloud seeding effects 348

Colorado River "15-mile" reach 620,898

Colorado squawfish (Ptychocheilus lucius) 769

Habitat 620

Data index 337, 437, 1199

Deadhorse Creek, forest management practices 1112

Energy development 33,1060

Fraser Experimental Forest 436, 1112

Fraser River 937

Gaging stations 1362

Gunnison River, fish studies $\quad 52,53,869$

Hydrologic models 1300

Instream Flow Incremental Model (IFIM) 869

Marginal economic value 112

Physical Habitat Simulation Model (PHABSIM) 869

Regulation 1234, 1240

Snowpack 110,413

Statistical summaries 927,928

Subalpine zone 695

Taylor River, fish studies $\quad 167,859,860,861,863,864,865,866$

U.S. Geological Survey data program evaluation 713

Utah 201

Variation 100

Water law 688

Water policy 688

Wetlands, hydrology 1000 
Streams

Classification $\quad 259,261,264$

Gunnison River 234

Water quality 888

Fraser Experimental Forest, water chemistry 1080

Insects, guidebook 1306

Reclamation, acid-mine drainage 965

Regulated

Algae 314

Flood studies 116

Rocky Mountains 1385

Substrate, aquatic biota production 924

Survey

Fish distribution 236,702

Uranium mill tailings site 1219

Temperature, harmonic analysis 1071

Subalpine fir (Abies lasiocarpa), evapotranspiration 454

Subalpine zone

Riparian vegetation classification 34

Streamflow 695

Watershed management $\quad 694$

Wetlands

Ecological characterization 1361

Hydrologic functions 1086

Hydrology 311, 1000

Vegetation 311

Subsidence potential, Delta County coal lease tracts 106

Suckers (Castostomidae), Gunnison-Arkansas Project 194

Sulfate 388

Summit County

Geology 535

Metal precipitation 1099

St. Louis Peak Roadless Area $45,46,363$

Snake River $59,60,61,62,784,785,786,787$

Water quality 101

Management 1157

Management plan 886, 1163

Superfund Enforcement Decision, Smuggler Mountain 1171

Superfund Record of Decision, Eagle Mine Site 1172

Superfund sites

Eagle River 1172

Biological assessment $\quad 539,540,761,948,1364$

Smuggler Mountain 1171

Surface water

Data records 301

Ground water, water supply interrelationship 585

Records 1200, 1202, 1205

Records index 337, 437, 1199

Sweitzer Lake 179

Fish survival and mortality 39

Water quality 102

Synthetic fuels development, water supply 1245

Tamarisk (Tamarix), fire, water and salinity relations 171

Taylor Park Reservoir $\quad 857,1102$ 
Effects on Gunnison River fishery 1352

Limnology 1227

Water quality 102

Taylor River

Fish studies $\quad 167,859,860,861,863,864,865,866,868$

Streamflow $167,859,860,861,863,864,865,866$

Water quality $289,1002,1365$

Taylor River Basin, ground water 456

Temperature 22, 1071, 1303, 1359

Ground water, maps 969

Tenmile Creek

Molybdenum

Geochemistry 618

Removal 701

Transport 617

Nonpoint source water pollution 266

Runoff 406

Water quality 410

Tessaria, fire, water and salinity relations 171

Thermal springs (see springs)

Three Lakes Water and Sanitation District, wastewater treatment facility, environmental impact statement 1088

Tomichi Creek

Fish studies, channelization effects 166

Flood studies 359

Water quality $289,1002,1365$

Tomichi Hot Springs 906

Trace elements 624

Cadmium 219, 220

Ground water, Colorado Plateau 592

Molybdenum 219, 220, 221

Uncompahgre Project area, soils 1077

Trace metals

Black Gore Creek 1073

Deer Creek 790

Eagle River 1073

Tracers

Snake River 790

Deer Creek 59,61

Lithium 60

Radon-222 585

Rhodamine WT dye 61

Snake River 59,60,61, 62

Tree-ring analysis 1010,1079

Trichoptera, Rocky Mountain regulated streams 1304

Trophic level classification

Blue Mesa Reservoir 80

Trout 870

Green Mountain Reservoir 333

Black Canyon of the Gunnison National Monument 869

Blue River 862

Brook trout (Salvelinus fontinalis), habitat 1340

Brown trout (Salmo trutta) 869, 1340

Black Canyon of the Gunnison National Monument 869 


\section{Habitat 1340}

Population dynamics, Taylor River 864

Colorado River cutthroat trout (Salmo clarki pleuriticus)

Habitat 88,1340

Status 121

Eagle River 865,866

Fryingpan River $862,863,865,866$

Gunnison River $862,863,869$

Ecology 945

Streamflow 53

Habitat 1340

Rainbow trout (Salmo gairdneri) 869

Roaring Fork River 865,866

Taylor River $\quad 863,864$

Trout Cover Rating Method 1340

Turkey Creek

Runoff 406

Water quality 101

Two Creek, water quality 1373

U.S. Department of Agriculture, salinity control planning process 513

U.S. Geological and Geographical Survey of the Territories 429, 497

U.S. Geological Survey, legislative support 273

Unaweep Canyon 717, 719

Stream profile evolution 925

Uncompahgre Basin Resource Area, instream flow assessment 124

Uncompahgre Project 113

Uncompahgre Project area

Irrigation drainage 180

Soils, trace elements 1077

Uncompahgre River

Dissolved solids 882

Flood control, Dallas Creek Water Project 1125

Flood studies 1132

Inorganics

Aquatic biota 896

Sediments 896

Nonpoint source water pollution 266

Runoff 406

Uncompahgre River Basin

Feasibility study $504,505,506$

Water quality 179,1182

Uncompahgre River Valley 758

Ground water 283, 796

Selenium, ground water 1372

Uncompahgre Springs 906

Unconsolidated deposits, Piceance Basin 1335

Upper Colorado River Basin Compact 1263

Upper Colorado River Commission, annual report 1264

Upper Colorado River Storage Project, Curecanti Unit 1357, 1358

Upper Eagle Valley Sanitation District, wastewater treatment facility 1159

Environmental impact statement 1168,1169

Upper Limit Design Rain Storm (ULDRS) 828

Uranium 1004

Water quality 1158,1242 


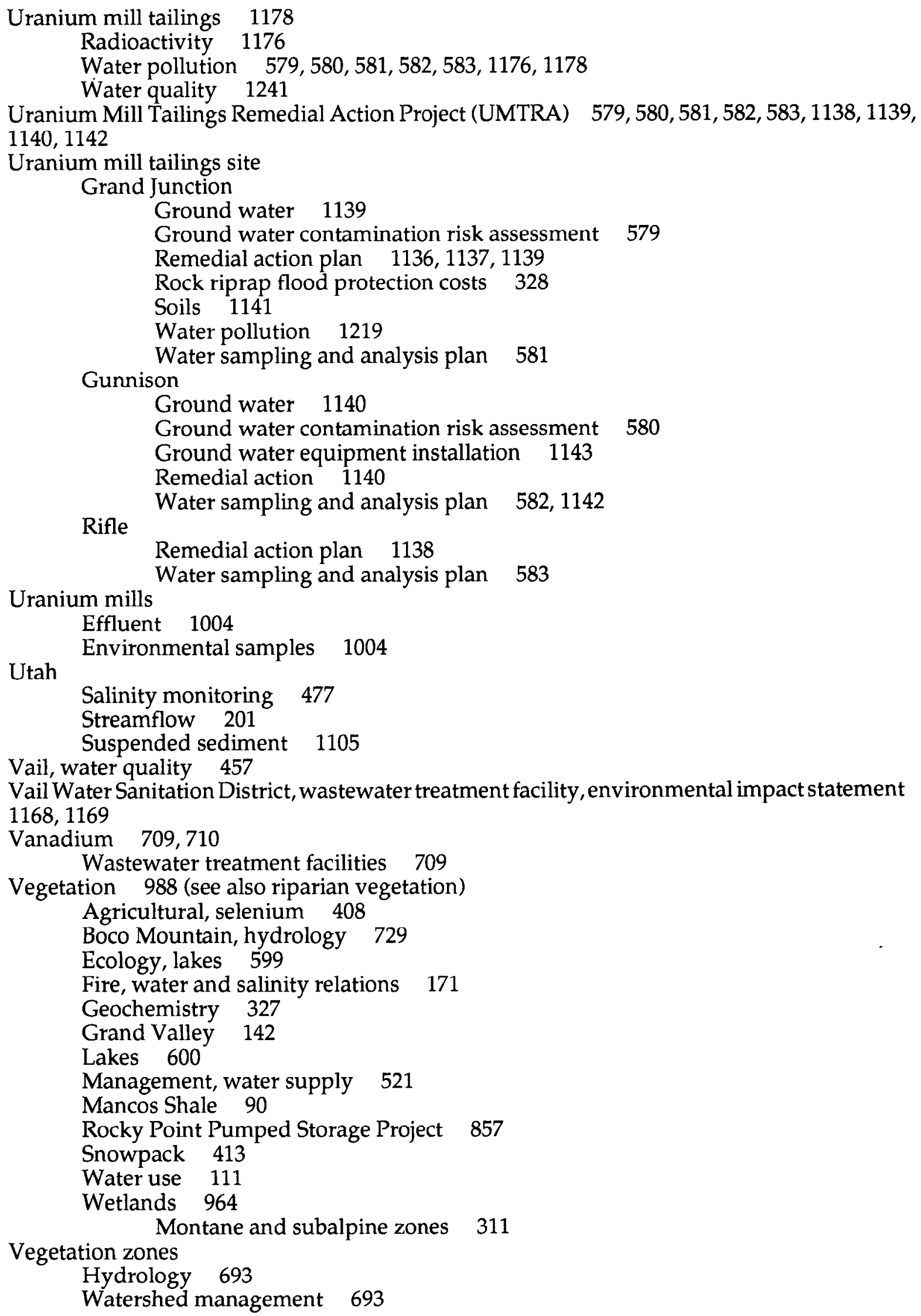


Vertebrates

Aquatic habitats 168

Grand Valley 142

Waste management, contaminant transport 951

Wastewater treatment facilities

Aspen Metro Sanitation District, environmental impact statement 1330

East River Valley, plan 184

Granby Sanitation District, environmental impact statement 360

Snowmass Water and Sanitation District, environmental impact statement 1330

Three Lakes Water and Sanitation District, environmental impact statement 1088

Upper Eagle Valley Sanitation District 1159

Environmental impact statement 1168,1169

Vail Water Sanitation District, environmental impact statement $\quad 1168,1169$

Vanadium 709

Water allocation 527

Climate change, hydrologic models 487

Fishes 721

Institutions, economic impacts 85

Wildlife 721

Water and sewer facilities plan, Eagle County 251

Water and sewer systems, Black Canyon of the Gunnison National Monument,

environmental assessment 271

Water balance 957, 958

Water chemistry, Fraser Experimental Forest streams 1080

Water conservation 844

Economic incentives 556

Water data catalog of information 1212

Water data system 1258

Water demand

Electricity generation 4

Oil shale 395

Water development 767

Ground water, state regulations 598

History 750

Policy 1038

Politics 747

State regulations 598

Wilderness legislation impacts 1320

Water diversion 892 (see also Colorado-Big Thompson Project)

Blue River-South Platte Project 126, 127

Geology 478

Dillon Reservoir 13

Fryingpan-Arkansas Project

Annual operating plans 162

Fish studies 394

Gunnison-Arkansas Project, fishes 194

Gunnison River 56

Hydrologic effects 13

Maps 605

Water hardness, Gunnison River Basin 1026

Water law 200, 1325, 1326

Energy development 586

Ground water 248, 776

Instream flow 987 


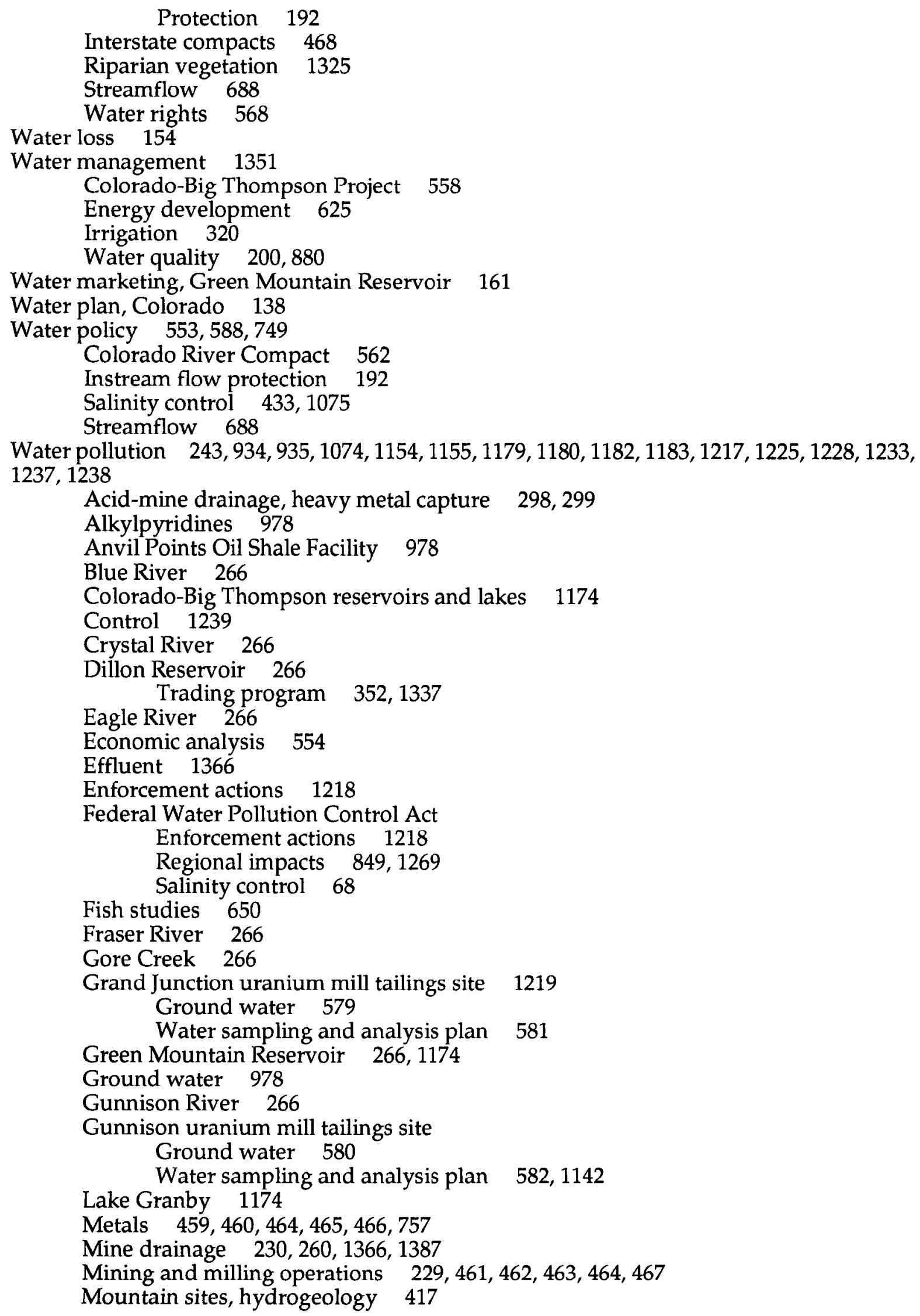


Nonpoint source $\quad 265,266,878,1021$

Dillon Reservoir trading program $\quad 352,1337$

Salinity $38,78,342,1011,1021$

Oil shale 931

Salinity control 601,976

Pulp mills 899

Waste 1301,1302

Rifle uranium mill tailings site, water sampling and analysis plan 583

Roan Creek 266

Roaring Fork River 266

Salinity 78,1154

Shadow Mountain Lake 1174

Slate River 266, 1366

Snake River 266

Tenmile Creek 266

Uncompahgre River 266

Uranium mill tailings $579,580,581,582,583,1176,1178$

Williams Fork River 266

Willow Creek 266

Water-power resources, Crystal River 687

Water quality $130,140,198,224,232,268,324,337,437,438,548,550,551,573,574,737,805$, $858,970,1155,1177,1181,1182,1183,1199,1201,1204,1205,1207,1209,1211,1225,1228,1244$, $1250,1251,1252,1253,1254,1255,1256,1257,1268,1323$

Acid-mine drainage 823,1339

Agriculture 822

Alkali Creek 182,1373

Alum Creek 1367

Ammonia 560, 881

Anthracite Creek 1367

Bacteria 665, 804

Battlement Mesa Project 1240

Beaver Creek 1373

Bibliography

Irrigation 1223

Salinity 807

Bighorn Creek 1373

Black Gore Creek 1373

Blue Mesa Reservoir 102, 522

Blue River 101, 333, 1160

Blue River Basin 1157 Management plan 886, 1163

Bluestone Reservoir Project 1184

Booth Creek 1373

Brush Creek 101, 231, 1373

Bureau of Reclamation projects 1371

Buttes Oil and Gas 23,973

Canyon Creek 823

Carbon Creek 182

Castle Creek 231

Cattle Creek Basin, ground water 103

Cebolla Creek 24, 25

Cebolla Hot Springs 391

Cement Creek 1002, 1365

Chipeta Creek 1367 
Cholera 972

Cimarron River 410

Cliff Creek 1367

Coal Creek 101, 182, 233, 823, 1002, 1367

Coal mining 451, 801, 1114, 1249

Cochetopa Creek 289

Colorado River Basin Water Quality Control Project $\quad 1175,1224,1232,1237,1238$, 1242

Colorado River Water Quality Improvement Program $\quad 141,143,146,148,149,150$, $155,160,164,607,830$

Cooper Creek 920

Cottonwood Creek 1367

Crawford Reservoir 102

Crested Butte, ground water 456

Cross Creek 101, 1373

Crystal River 101, 231, 233, 1002

Crystal River Basin, ground water 103

Curecanti National Recreation Arca 1, 2, 852, 853

Dallas Creek Water Project 1231

Data and sampling programs analysis 834

Data index 1023

Deldorado Creek 24, 25

Delta County 1367

Dillon Reservoir 102, 1160

Dissolved solids 2

Maps 388, 389

District 10 management plan $\quad 235,302,303$

Dotsero Springs 336

Eagle 457

Eagle County $101,251,886$

Eagle River 101, 410, 438, 1373

Eagle River Basin 1373 Management plan 886

Eagle River Valley 457

East River $182,289,290,304,410,888,920,1002,1365$

East River Basin 1265 Ground water 456

Eby Creek 1373

Economic models 1248

Effluent, bacteria 804

Energy development $72,74,451,794,801$

Fishes 1374

Fraser River 10, 101, 756

Fraser River Basin, management plan 886

Fruita 560

Fryingpan River 101, 231

Glenwood Springs 336

Gore Creek 101, 755, 1373

Grand County 101,886

Grand Junction 560

Grand Lake 102, 1147, 1170

Grand Mesa Project 1153

Green Mountain Reservoir 102, 333

Ground water $509,510,565,573,574$ 
Cattle Creek Basin 103

Crested Butte 456

Crystal River Basin 103

Data 1395

Dissolved solids 389

East River Basin $\quad 456$

Fluoride 397

Gunnison 456

Gunnison River Basin 1395

Maps $389,397,456,968$

Ohio Creek Basin 456

Radiochemical analysis 1017

Rifle Oil Shale Facility $\quad 434,435$

Routt County 281

Taylor River Basin 456

West Sharrard Creek Basin 434, 435

Western Slope monitoring program 1394

Grouse Creek 1373

Gunnison, ground water 456

Gunnison County 24, 25, 187, 920, 1002, 1365, 1367

Gunnison irrigation system 665

Gunnison River $234,289,410,638,851,1002,1365,1367$

Gunnison River Basin 179, 234, 289, 851, 884, 885, 888, 1182, 1365

Ground water 1395

Gypsum Creek 101, 1373

Hensen Creek 1365

Homestake Creek 1373

Hunter Creek 231

Hydrologic models, salinity $\quad 699,1289$

Inorganic solutes 821

Inorganics 1

Iron Hill 973

Irrigation 544, 822

Irrigation drainage 179,180

Irrigation return flow 135, 320, 342

Irrigation systems 665

Lake Creek 1373

Lake Fork River 1365

Lake Granby $102,1147,1170$

Leroux Creek 1367

Macroinvertebrates, aquatic 1374

Management $200,880,1157,1380$

Maps 457

Plan 235, 302, 303, 537, 886, 1163

Dissolved solids 388,389

Fluoride 397

Ground water $389,397,456,968$

Maroon Creek 231

Measurements 638

Mesa County 972

Metal-mine drainage 823

Metals 1, 1073

Mill Creek 101, 1373

Mine drainage 823,1339 
Mine spoils 792

Monitoring report, Denver Water Department 983

Morrow Point Reservoir 102

Mount Emmons 182

Muddy Creek 1367

National Water-Quality Assessment Program (NAWQA)

North Beaver Creek 24, 25

Oh-Be-Joyful Creek 823, 1002

Ohio Creek 182

Ohio Creek Basin, ground water 456

Oil shale $434,435,1001$

Waste 1072

Oil shale development 801

Surface-water parameters 635

Paonia Reservoir 102

Peru Creek 101, 823, 1388

Pesticides 2, 1232

Pitkin County 101, 886

Pitkin Creek 1373

Plateau Creek 202

Powderhorn 24, 25, 973

Project Rulison, radiochemical analysis $\quad 202,682,1283$

Public water supplies 325

Quartz Creek 289, 1365

Radiation 2

Radioactive contaminants 1232,1242

Radiochemical analysis $202,682,1017,1283$

Radium Monitoring Network 1158, 1242

Radium-226 1158, 1242

Radon-222 1241

Red Mountain Creek 823

Redsandstone Creek 1373

Rifle Gap Reservoir 102

Rifle Oil Shale Facility 434, 435

Road Beaver Creek 24, 25

Roaring Fork River 101, 231, 410

Roaring Fork River Basin, management plan $\quad 537,886$

Robinson Creek 1367

Rock Creek Reservoir 178

Rocky Point Pumped Storage Project 857

Routt County 101,886

$$
\text { Ground water } 281
$$

Ruedi Reservoir 102

Salinity $609,763,1148,1149,1152,1232$

Stochastic analysis 745

Salinity control 1062

Selenium 408

Shadow Mountain Lake 102, 1147, 1170

Slate River $\quad 182,289,290,304,410,823,888,1002,1365$

Snake River 101, 823

Snowmass Creek 231

Springs

Parachute Creek Basin 175

Roan Creek Basin 175 
Standards $125,261,263,264$

Gunnison River Basin 234

Salinity $244,245,246,247,262$

Stations, index 489

Stream classification 888

Summit County $101,886,1157,1163$

Sweitzer Lake 102, 179

Taylor Park Reservoir 102

Taylor River 289, 1002, 1365

Taylor River Basin, ground water 456

Tenmile Creek 410

Tomichi Creek 289, 1002, 1365

Trace elements 624

Trace metals 1073

Turkey Creek 101

Two Creek 1373

Uncompahgre River Basin $\quad 179,1182$

Uranium 1158, 1242

Uranium mill tailings 1241

Vail 457

Waunita Hot Springs 187,391

West Divide Project 1234

West Sharrard Creek Basin $\quad 434,435$

Western Slope, ground water 1394

Wetlands, Homestake Project Phase II 354

Williams Fork Gravity Project 361

Williams Fork Reservoir 102

Williams Fork River 10

Willow Creek Reservoir 102

Wolford Mountain Reservoir 178

Water requirements 452,1236

Oil shale waste stabilization 1376

Water resources $138,242,256,257,324,384.448,553,573,574,577,696,890,929,1146,1205$, $1206,1211,1213,1216,1243,1244,1250,1251,1252,1253,1254,1255,1256,1257,1261,1262$, 1384

Arid lands, energy development 86

Coal mining 14, 15

Colorado River Basin Salinity Control Project, Grand Valley Unit 159

Crested Butte Coal Field 14

Dallas Creek Water Project 1231

Delta County 1324

Development 966,1128

History 750

Legislation 1318

Politics 747,1318

Salinity management $\quad 174$

Energy 400, 402

Energy development 404,405

Energy production 3

Grand Hogback Coal Field 15

Gunnison River Basin 258, 332

Climate change $29,47,494$

Management, hydrologic models 75

Mesa County 1324

278 Bibliography, Indices, and Data Sources of Water-Related Studies, Upper Colorado River Basin, Colorado and Utah, 1872-1995 


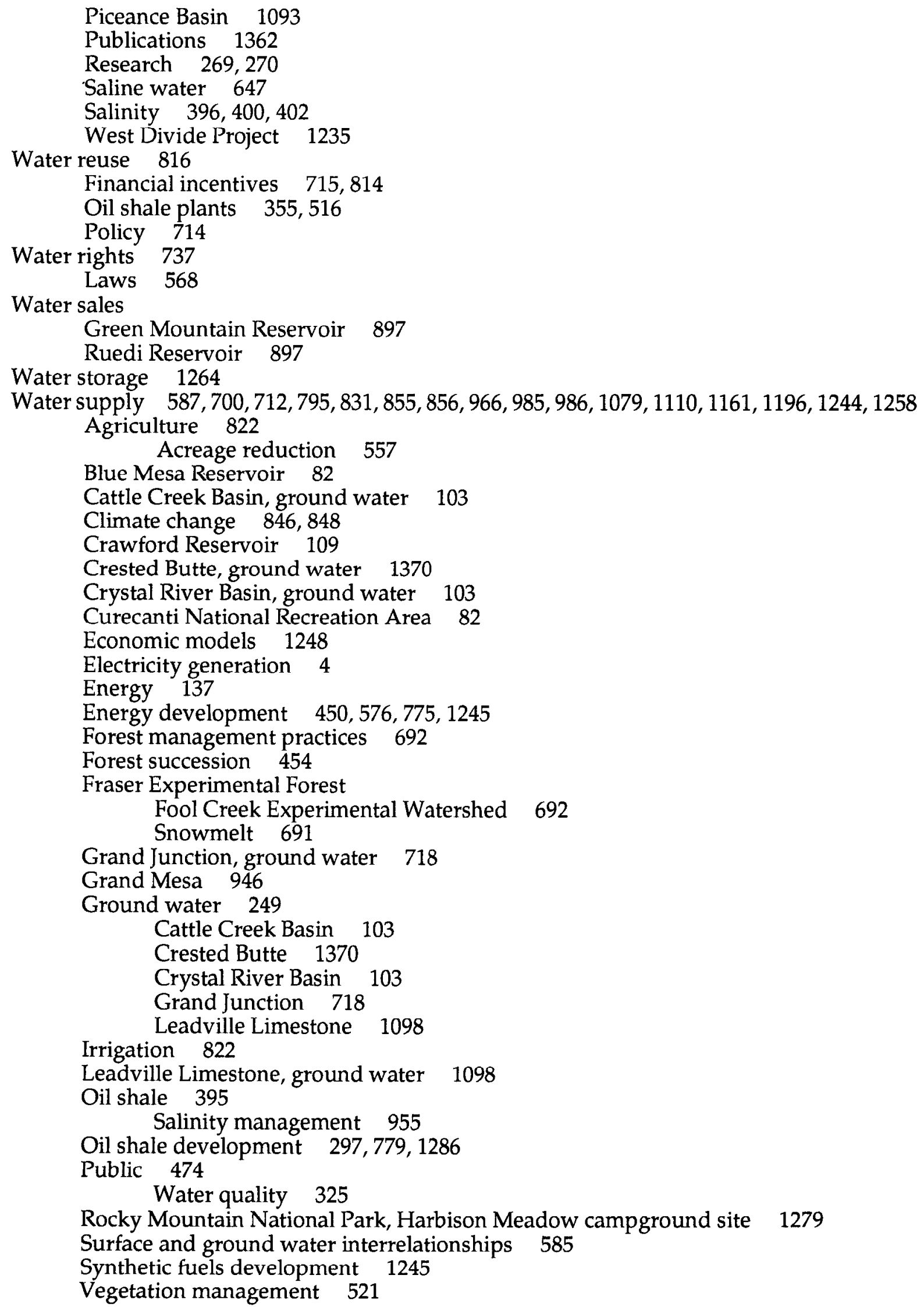


Weather modification 622

Water temperature 22, 1071, 1303, 1359

Ground water, maps 969

Water use $154,407,683,711,712,1244,1246,1264$

Aspen (Populus) 111

Crops, saline ground water 655,656

Energy 403

Energy development $73,146,401,576$

Dotsero Springs 335

Glenwood Springs 335

Grasses 660

Grassland 111

Ground water, state regulations 598

Gunnison River Basin, irrigation 1277

Irrigation 661

Oil shale 995

Oil shale development 473

Oil shale plants 355,516

Phreatophytes 1239

Rocky Point Pumped Storage Project 857

Saline water $67,99,146$

Transport systems $\quad 766$

Spruce (Picea) 111

State regulations 598

Water pollution control, oil shale residues 1376

Water year review 855

Watershed management

Rocky Mountains 693, 694

Subalpine zone 694

Vegetation zones 693

Waunita Hot Springs 1070,1310

Geothermal resource assessment $\quad 838,1381$

Water quality 187,391

Weather modification (see also cloud seeding)

Assessment 1333

Atmospheric water balance 958

Colorado River Basin Pilot Project, evaluation report 349

Environmental assessment 488

Environmental impact statement 132

Wells 777

Water supply 622

Artesian 66

Basic data 81

Garfield County 567

Hydrogeochemical data 42

Location, crystalline rocks 399

Maps 43

Mesa County 567

Project Rulison area 567

Radiochemical analysis $\quad 682,1283$

West Divide Project

Fish and wildlife analysis 169

Public health 1234,1235

Water quality 1234 


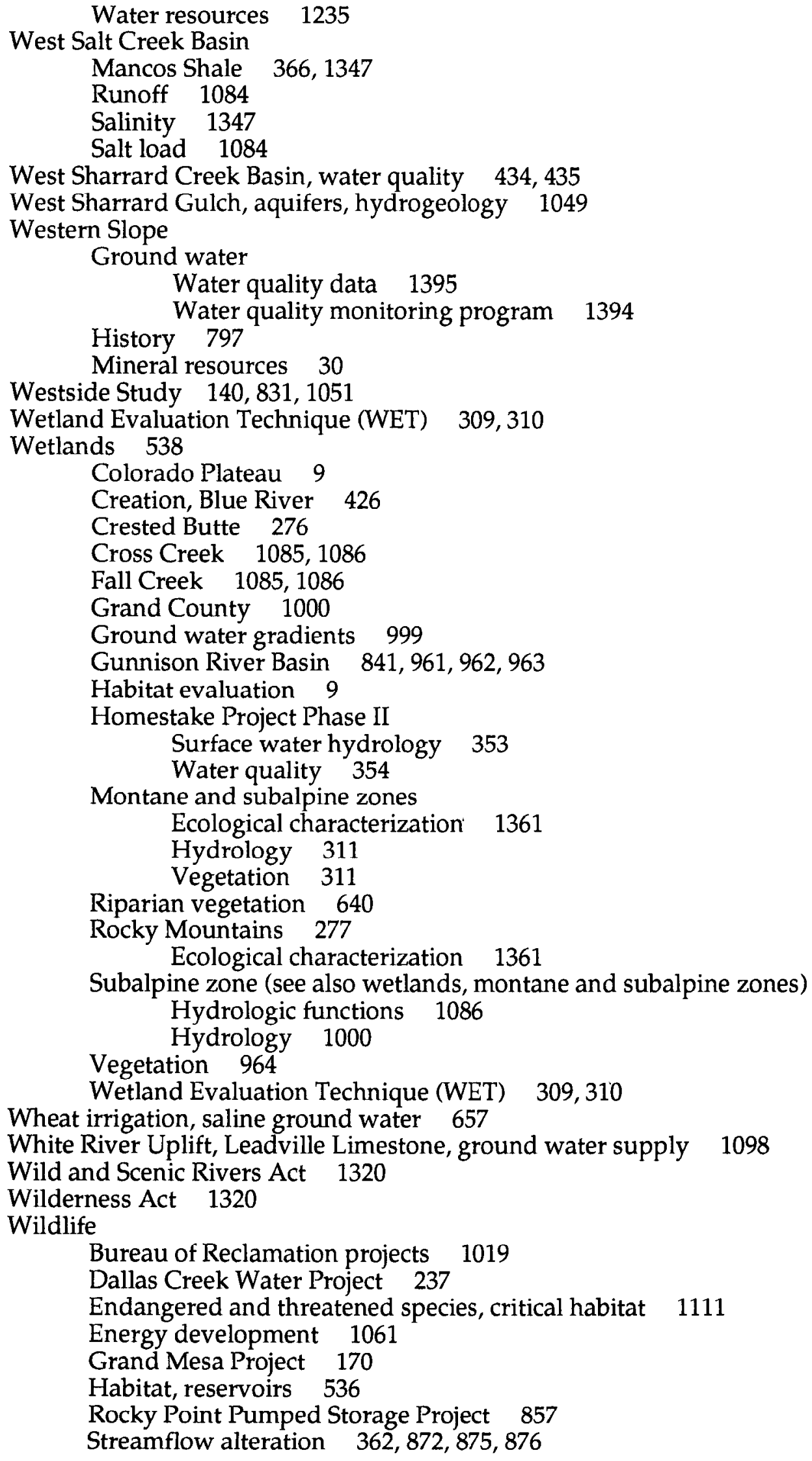


Water allocation 721

West Divide Project 169

Williams Fork Further Planning Area, geochemical data 46

Williams Fork Gravity Project, water quality 361

Williams Fork Reservoir

Evaporation 390, 1059

Phosphorus budget 670

Water quality 102

Williams Fork River

Nonpoint source water pollution 266

Water quality 10

Williams Fork River Basin, geology 350

Williams Fork Roadless Area

Geochemical maps 45

Mineralogy maps 363

Willow Creek, nonpoint source water pollution 266

Willow Creek Reservoir, water quality 102

Willow (Salix), fire, water and salinity relations 171

Windy Gap Project, environmental statement 145, 161

Windy Gap Reservoir, impact on sediment transport 1309

Wolford Mountain Reservoir

Water quality and downstream channel effects 178

Sedimentation 998

Xyrauchen texanus, Colorado River "15-mile reach" $\quad 897,898$

Zinc

Acid-mine drainage

Ion exchange capture 298

Sediment adsorption 735

Streambed sorption 736

Metal-mine drainage 823

Zoobenthic fauna 1308

Zooplankton, acid precipitation susceptibility $\quad 305$ 